\author{
UNIVERSIDADE DE SÃO PAULO \\ INSTITUTO DE ESTUDOS BRASILEIROS \\ PROGRAMA DE PÓS-GRADUAÇÃO \\ CULTURAS E IDENTIDADES BRASILEIRAS
}

HENRIQUE GERKEN BRASIL

Relações Externas Brasil-África: Da Política Externa Independente ao

Governo Lula

Versão Corrigida

SÃO PAULO 
2016

UNIVERSIDADE DE SÃO PAULO

INSTITUTO DE ESTUDOS BRASILEIROS

PROGRAMA DE PÓS-GRADUAÇÃO

CULTURAS E IDENTIDADES BRASILEIRAS

\section{Relações Externas Brasil-África: Da Política Externa Independente ao Governo Lula}

Versão Corrigida

Henrique Gerken Brasil

Dissertação apresentada ao Programa de

Pós-Graduação Culturas e Identidades Brasileiras do Instituto de Estudos Brasileiros da Universidade de São Paulo para a obtenção do título de Mestre em Filosofia

Área de Concentração: Estudos Brasileiros

Orientador: Prof. Dr. Alexandre de Freitas Barbosa 
Autorizo a reprodução e divulgação total ou parcial deste trabalho, por qualquer meio convencional ou eletrônico, para fins de pesquisa, desde que citada a fonte.

DADOS DE CATALOGAÇÃO NA PUBLICAÇÃO (CIP)

Serviço de Biblioteca e Documentação do

Instituto de Estudos Brasileiros da Universidade de São Paulo (c) reprodução total

\section{Brasil, Henrique Gerken}

Relações Externas Brasil- África : da política externa independente ao governo Lula / Henrique Gerken Brasil -- São Paulo, 2016.

Orientador : Prof. Dr. Alexandre de Freitas Barbosa.

Dissertação (Mestrado) - Universidade de São Paulo. Instituto de Estudos Brasileiros. Programa de Pós-Graduação. Área de concentração: Estudos Brasileiros. Linha de pesquisa: Brasil: a realidade da criação, a criação da realidade.

Versão do título para o inglês: Brazil-Africa external relations : from the independent foreign policy to Lula government.

Descritores: 1. Política externa - 1961-2010 - Brasil; África 2. Relações exteriores - 1961-2010 - Brasil; África 3. Brasil 4. África I. Universidade de São Paulo. Instituto de Estudos Brasileiros. Programa de Pós-Graduação II. Título. 
BRASIL, Henrique Gerken

Relações Externas Brasil-África: da Política Externa Independente ao Governo Lula

Dissertação apresentada ao Programa de Pós-Graduação em Culturas e Identidades Brasileiras do Instituto de Estudos Brasileiros da Universidade de São Paulo, para obtenção do título de Mestre em Filosofia.

Área de Concentração: Estudos Brasileiros

Aprovado em:

Banca Examinadora

Prof. Dr.

Instituição: Assinatura:

Prof. Dr.

Instituição: Assinatura:

Prof. Dr.

Instituição: Assinatura: 
Para meu tio Max,

In memoriam 


\section{AGRADECIMENTOS}

Devo começar meus agradecimentos à minha família, pelo apoio incondicional em todos os momentos; pela paciência e companhia de minha mãe-peregrina, Dona Maike Ursula, em mais uma longa caminhada; pelo apoio acadêmico e amigo da minha irmã Bettina e de meu irmão Alexandre; pelas conversas sempre estimulantes com meu tio Otto e pela alegria da minha tia Ana, pela amizade de meus primos Gustavo, Alessandra, Andrea e Camila, que me escutaram muitas vezes.

Devo muitos agradecimentos ao meu orientador, Alexandre de Freitas Barbosa, pela oportunidade não apenas de entrar no mundo acadêmico mas pela orientação sempre presente e honesta, e também por compartilhar generosamente tanto conhecimento, e pela convivência nesses anos, que seguramente me enriqueceu.

À CAPES pela bolsa de estudos concedida no último ano da pesquisa.

Agradeço a todos os professores do IEB com quem pude conviver nesses últimos anos e que sempre me estimularam a pesquisar e tomar gosto pelo Instituto, além de servirem de exemplo de profissionais e acadêmicos. Agradeço especialmente à Profa. Flávia, sempre me incentivando, desde que entrei no IEB; aos Profs. Marcos, Jaime e Paulo, cujas conversas também sempre foram estimulantes; à Telê e Vanderli, e à Ana Paula, com quem também muito aprendi.

Agradeço a todos os funcionários do IEB com quem convivi nesses anos - tenho certeza que cresci muito profissional e pessoalmente por meio do convívio de tantas pessoas trabalhadoras e amigas. Agradecimento especial ao pessoal da Pós-graduação e Apoio ao Aluno, pelo apoio nesses anos: Walquíria, Lúcia, Daniele. À Magda agradeço muitíssimo pelo apoio amigo, conversas e conselhos, tanto acadêmicos quanto pessoais e profissionais. À Bete agradeço a oportunidade do convívio e pelas conversas de apoio.

Um agradecimento especial que merece todo um parágrafo é dedicado a Maria Cristina Pires, chefe da Pós-graduação. Muito obrigado pela oportunidade de trabalhar ao seu lado e pela convivência todos esses anos, quando aprendi muito profissional e academicamente. Não exagero em dizer que se não fosse por você, não estaria agora terminando este trabalho. Cris, muito obrigado! 
Este trabalho provavelmente não seria o mesmo sem a convivência dos meus amigos e colegas do IEB, cujas discussões, acadêmicas ou não, estimularam a pesquisa e tornaram toda essa caminhada mais prazerosa. Eduardo, Lucas, Regiane, Marina, Vinicius: muito obrigado pela companhia e amizade.

Devo muito aos professores do Departamento de História da FFLCH, especialmente aos Profs. Rafael Marquese, Miguel Palmeira, Marina de Mello e Souza e Gabriela Pellegrino, que sempre me incentivaram, com aulas e conversas, a seguir adiante com o estudo de História.

Aos meus amigos franciscanos, Manuela, Evorah, Jefferson, Fabio, pelo apoio e amizade, e especialmente a Daniel e Priscila, cuja ajuda e apoio foram fundamentais na reta final da pesquisa.

Agradeço também aos funcionários dos Ministérios das Relações Exteriores, da Saúde, da Educação, da Agência Brasileira de Cooperação e da Embrapa, pela disposição a conversar e pela imensa ajuda no final da pesquisa.

Aos meus amigos Hugo, Kauê e o mito Tato Carbonaro, por todos os momentos juntos de estudo, de amizade e de bebida ao longo desses últimos anos.

Por último, e mais importante, agradeço à Juliana Medeiros e à Leiloca, por tanto amor, carinho e compreensão nessa jornada. 


\section{RESUMO}

BRASIL, Henrique Gerken. Relações Externas Brasil-África: da Política Externa Independente ao Governo Lula. Dissertação (Mestrado) - Instituto de Estudos Brasileiros, Universidade de São Paulo. São Paulo, 2016.

Este trabalho trata da Política Externa Brasileira durante o período de 1961 a 2010, no tocante às relações com o continente africano. Em primeiro lugar, busca-se uma visão diacrônica dessas relações desde a chamada Política Externa Independente, em 1961, quando se esboça uma mudança da Política Externa Brasileira para a África, até o fim do governo Fernando Henrique, em 2002. Em seguida, empreende-se uma análise mais aprofundada dessa política no governo Lula (2003-2010), com uma minuciosa pesquisa de dados sobre as diversas iniciativas desse governo em relação ao continente africano. Com isso, busca-se concluir a natureza da política externa brasileira para a África.

Palavras-chave: Política externa - 1961-2010 - Brasil; África. Relações exteriores - 19612010 - Brasil; África. Brasil. África. 


\begin{abstract}
BRASIL, Henrique Gerken. Brazil-Africa External Relations: from the Independent Foreign Policy to the Lula Government. Dissertação (Mestrado) - Instituto de Estudos Brasileiros, Universidade de São Paulo. São Paulo, 2016.

This study discusses the Brazilian Foreign Policy during the period from 1961 to 2010, in regard to the relations with the African continent. First, it builds a diachronic perspective of such relations beginning with the so-called Independent Foreign Policy (1961), when a shift in such relations is first outlined, until the end of the Fernando Henrique government (2002). Afterwards, it analyses more thoroughly these relations under the Lula government (20032010), with a detailed research about the different initiatives of this government towards the African continent. Thereby, it attempts to suggest the true nature of the Brazilian foreign policy towards Africa.
\end{abstract}

Keywords: Foreign Policy - 1961-2010 - Brazil; Africa. Foreign Relation - 1961-2010 Brazil; Africa. Brazil. Africa. 


\section{LISTA DE GRÁFICOS}

Gráfico 1 - Fluxo Comercial Brasil-África 1997-2002 ......................................................... 61

Gráfico 2 - Orçamento da ABC e total da Cobradi em Cooperação técnica (em U\$)............ 101

Gráfico 3 - Orçamentos para África e total em execução de projetos (US\$) ......................... 102

Gráfico 4 - Distribuição de Projetos de cooperação por países 2003-2010 ........................... 104

Gráfico 5 - Número de projetos em relação ao orçamento da ABC, para África (U\$) .......... 106

Gráfico 6 - Distribuição de Projetos por principais setores no governo Lula ........................ 106

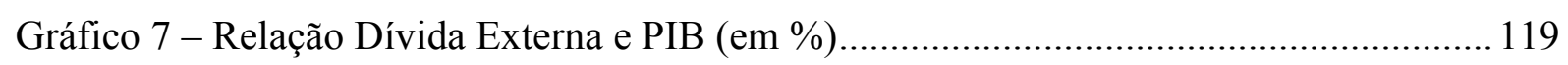

Gráfico 8 - Comércio total e Saldo do comércio Brasil-África 2003-2010, em US\$ bilhões 129

Gráfico 9 - Participação (\%) na exportações brasileiras por blocos, 2003-2010 ................... 130

Gráfico 10 - Participação (\%) na importações brasileiras por blocos, 2003-2010 ................. 131

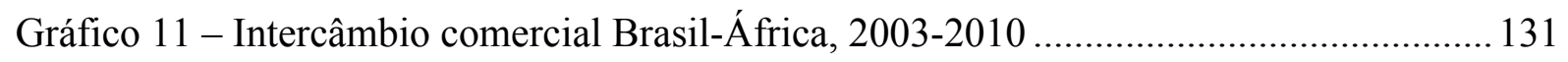




\section{LISTA DE TABELAS}

Tabela 1 - Principais destinos e número de escravizados.................................................... 20

Tabela 2 - Visitas de Estado do Presidente Lula por região ................................................... 82

Tabela 3 - Países africanos visitados pelo presidente Lula .................................................. 83

Tabela 4 - Visitas de Estado e Multilaterais por ano e destino............................................. 85

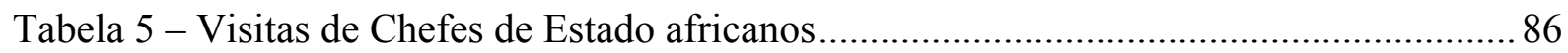

Tabela 6 - Negociação de Dívidas do Brasil com países africanos no Clube de Paris.......... 115

Tabela 7 - Relação de Perdão de Dívidas e Renegociação com países africanos................... 117

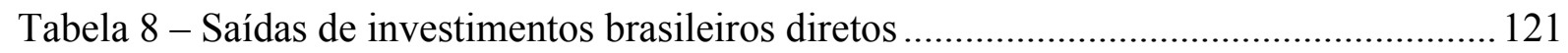

Tabela 9 - Investimentos diretos brasileiros no exterior a países africanos 2003-2009 ........ 122

Tabela 10 - Índice de Regionalidade por empresa brasileira na África................................. 123

Tabela 11 - Operações de financiamento do BNDES na África .......................................... 126

Tabela 12 - Participação (\%) dos principais parceiros na balança com a África 2003-2010 132

Tabela 13 - Participação (\%) no comércio brasileiro para África, por região ........................ 133

Tabela 14 - Participação (\%) na Exportação e Importação brasileiros - CPLP/PALOPs..... 134

Tabela 15 - Principais produtos exportados por países africanos do Brasil, 2007-2010 ....... 135

Tabela 16 - Principais produtos importados para o Brasil, por países, 2007-2010 ............... 136

Tabela 17 - Participação (\%) na exportação brasileira, por categoria ................................... 137

Tabela 18 - Principais fornecedores de petróleo e participação no comércio brasileiro ........ 138 


\section{LISTA DE MAPAS}

Mapa 1 - Regiões de origem dos escravizados levados ao Brasil, 1800-1850. 20

Mapa 2 - Competências das Divisões de África no Itamaraty 69

Mapa 3 - Embaixadas brasileira na África por ano 89

Mapa 4 - Distribuição da classificação de postos no exterior em 2010 .92

Mapa 5 - Intensidade dos projetos de cooperação por país . 105

Mapa 6 - Relação de embaixadas e países receptores de projetos. 113

Mapa 7 - Distribuição geográfica das empresas brasileiras na África 125 


\section{LISTA DE SIGLAS}

ABC - Agência Brasileira de Cooperação

ACR - Arranjo Contingente de Reservas do BRICS

ACIF - Acordos de Cooperação e Facilitação de Investimentos

APPI - Acordos para Promoção e Proteção de Investimentos

ASA - Cúpula América do Sul-África

IBAS - Fórum de Diálogo Brasil-Índia-África do Sul

IBEAA - Instituto Brasileiro de Estudos Afro-Asiáticos

IBGE - Instituto Brasileiro de Geografia e Estatística

IPEA - Instituto de Pesquisa Econômica Aplicada

ISEB - Instituto Superior de Estudos Brasileiros

BRICS - Grupo Brasil, Rússia, Índia, China e África do Sul

CACEX - Carteira de Comércio Exterior do Banco do Brasil

CHDD - Centro de História e Documentação Diplomática

CID - Cooperação Internacional para o Desenvolvimento

CGFome - Coordenadoria Geral de Ações Internacionais de Combate à Fome

CPLP - Comunidade dos Países de Língua Portuguesa

CSONU - Conselho de Segurança da ONU

CSS - Cooperação Sul-Sul

FAO - sigla em inglês para Organização das Nações Unidas para Alimentação e Agricultura

PEI - Política Externa Independente

MRE - Ministério das Relações Exteriores

NBD - Novo Banco de Desenvolvimento do BRICS

OMC - Organização Mundial do Comércio

ONU - Organização das Nações Unidas

OTAS - Organização do Tratado do Atlântico Sul

PALOP - Países Africanos de Língua Oficial Portuguesa

PT - Partido dos Trabalhadores

UDN - União Democrática Nacional

ZOPACAS - Zona de Paz e Cooperação do Atlântico Sul 


\section{SUMÁRIO}

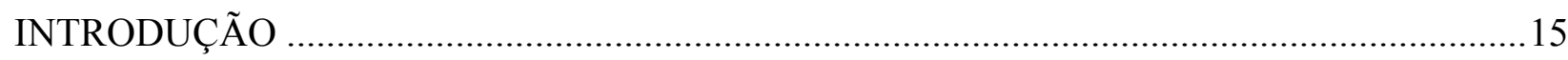

Capítulo 1: A Política Externa Brasileira Para África no Século XX ......................18

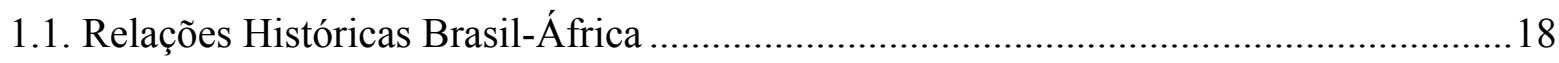

1.1.1. Período Colonial até Primeira República ........................................................... 19

1.1.2. Governo Jânio Quadros e João Goulart (1961-1964).......................................... 26

1.1.3. Governo Castelo Branco e Costa e Silva (1964-1969) .......................................... 41

1.1.4. Governo Médici (1969-1974)............................................................................ 45

1.1.5. Governo Geisel (1974-1979)...................................................................... 50

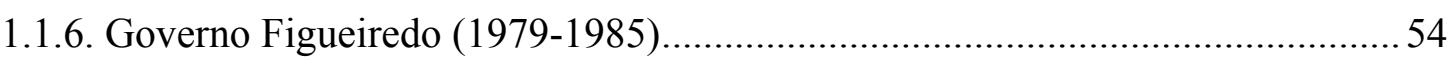

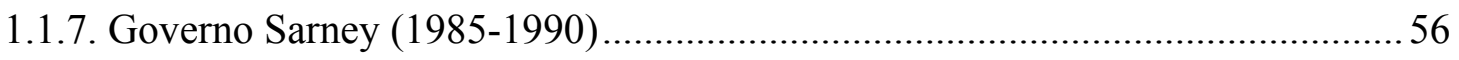

1.1.8. Governos Collor e Itamar (1991-1994) ......................................................... 58

1.1.9. Governo Fernando Henrique (1995-2002) …………………………………..... 59

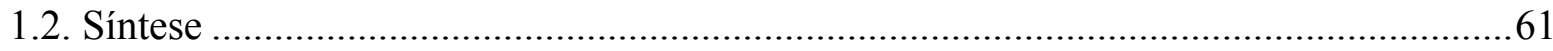

Capítulo 2 - A Política Externa Do Governo Lula (2003-2010).......................................67

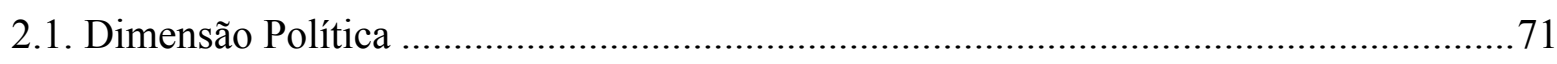

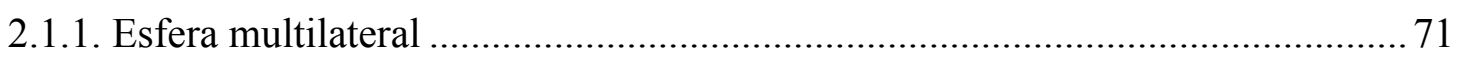

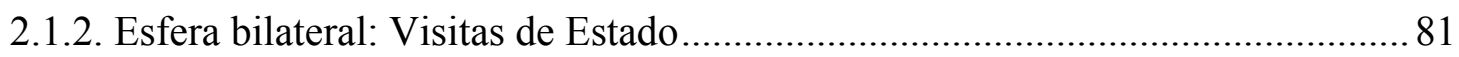

2.1.3. Esfera bilateral: Abertura de Embaixadas ......................................................... 88

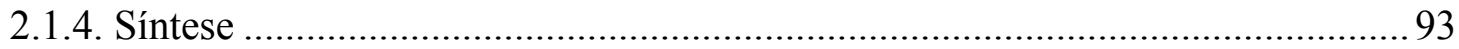

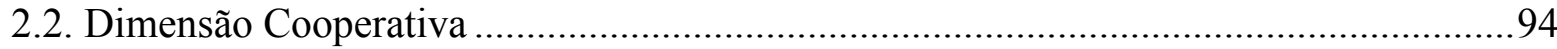

2.2.1. Definições e histórico da Cooperação Internacional Brasileira ........................... 94

2.2.2. A Cooperação brasileira para África no período Lula ...................................... 100

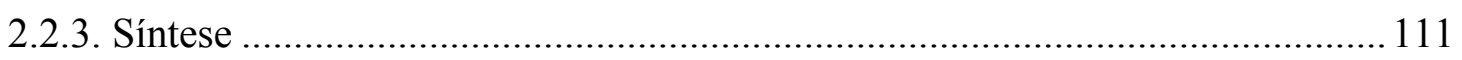

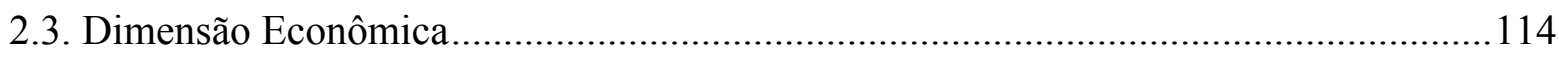

2.3.1. Perdão de Dívidas......................................................................................... 114

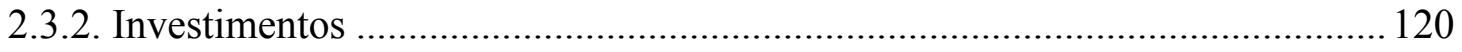

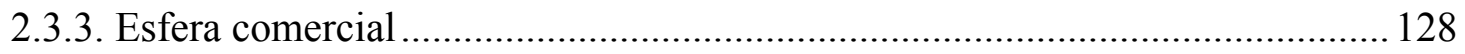

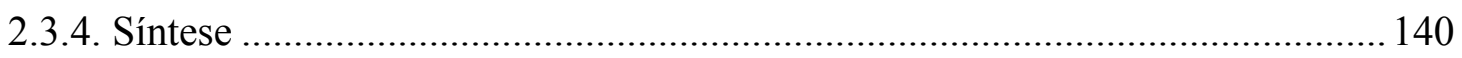




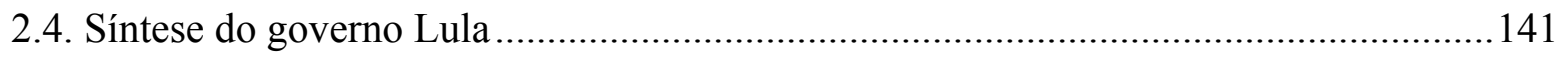

Capítulo 3 - A Política EXterna PARA A África nos discursos e nos debates ............143

3.1. As relações Brasil-África na retórica de Lula e Amorim ..............................................143

3.2. A política para África na mídia impressa ................................................................. 158

3.3. A política externa para África no meio acadêmico e intelectual..................................165

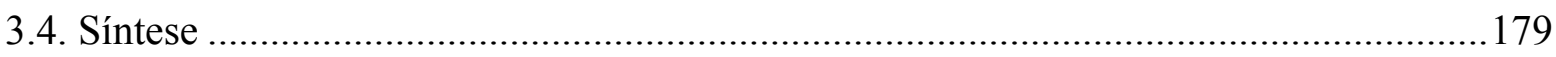

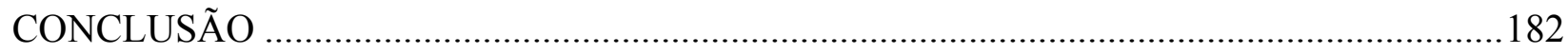

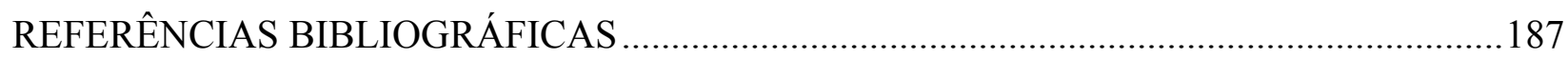

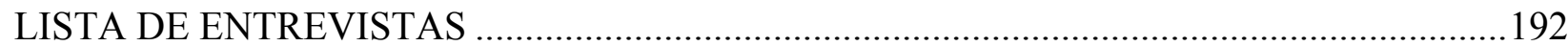




\section{INTRODUÇÃo}

Essa dissertação trata das relações externas entre o Brasil e a África, principalmente no que concerne a Política Externa Brasileira. O recorte temporal escolhido vai de 1961 a 2010, levando em consideração, de um lado, o Ano da África, o auge das descolonizações na década de 1960, e o lançamento da Política Externa Independente no Brasil; e de outro lado, o período do governo Lula, por ter representado uma mudança em relação a períodos anteriores, particularmente pelo destaque dado às relações com o continente africano. Esse trabalho tem como hipótese a evolução de uma política externa brasileira africana, ou seja, de uma política externa mais ativa em relação ao continente africano, especialmente no último período analisado. Houve, afinal, o desenvolvimento de uma política externa brasileira para a África? Dessa forma, ao observar o conjunto da política para a África, o trabalho questiona a sustentabilidade e coerência da mesma, consistindo em uma "política africana" propriamente dita.

Este trabalho se inicia com a análise da política externa brasileira para a África a partir do governo Jânio Quadros, quando ocorre um primeiro esboço de aproximação com "jovens" nações africanas, no auge da descolonização. Porém, como afirma José Honório Rodrigues, uma política africana propriamente dita não foi formulada, tendo em vista a diferença entre o discurso e a prática da política externa brasileira. O objetivo dessa parte, ao traçar uma perspectiva diacrônica dessas relações, de 1961 ao governo Fernando Henrique, é investigar as prioridades de cada governo em relação ao continente africano, percebendo se em algum momento houve uma intensificação ou aprofundamento de uma política propriamente africana.

O segundo capítulo do trabalho concentra-se no governo de Luis Inácio Lula da Silva, pois a relação com o continente africano foi um dos principais temas de sua política externa, alinhada ao eixo maior da ênfase nas relações com os países em desenvolvimento, as relações Sul-Sul. O questionamento de Rodrigues, utilizado como inspiração teórica, também parece fazer sentido neste período, considerando este momento um "relançamento" da política africana brasileira e uma "mudança de rumo" das relações do Brasil com a África. Nesse 
sentido, é necessário o exame mais detalhado das diversas iniciativas desse governo, também considerando a perspectiva histórica dessas relações.

O terceiro capítulo cuida do aspecto retórico da política externa do governo Lula para a África. Nesse ponto, o trabalho busca analisar a influência desse aspecto na política com relação à África. Além disso, analisaremos o debate suscitado pela priorização de Lula aos países africanos, especialmente na mídia impressa, na qual ocorreu forte discussão, muitas vezes ideológica e pouco informada por dados concretos, o que afetou em menor medida o cenário acadêmico. Ambos os lados defendem certa concepção de "interesse nacional": a aproximação com a África, afinal, vai ao encontro do interesse nacional?

Com isso em mente, o trabalho está divido em 3 capítulos, além desta introdução e conclusão. Como dito, o primeiro capítulo trata das relações entre o Brasil e os países africanos na longa duração, no período compreendido entre 1961 e 2002, com subdivisões referentes a cada governo do período, buscando as especificidades das relações com a África em cada momento. Em termos metodológicos, foi feita uma pesquisa bibliográfica e de fontes primárias, especialmente relatórios do Ministério das Relações Exteriores, jornais e depoimentos dos chanceleres de cada período, além de dados empíricos sobre comércio e investimento, buscando uma perspectiva diacrônica das relações externas, observando rupturas e continuidades na formulação da política externa. Devo observar que parte da pesquisa foi facilitada pela organização do Acervo de José Honório Rodrigues, sob guarda do Instituto de Estudos Brasileiros. No tema que trata esse trabalho, é fundamental o contato com o trabalho de José Honório Rodrigues, um dos principais intelectuais que repensou as relações Brasil-África, principalmente da perspectiva brasileira, considerado por Alberto da Costa e Silva o melhor trabalho no tema ${ }^{1}$.

O segundo capítulo trata especificamente do período da administração do presidentes Luis Inácio Lula da Silva, de 2003 a 2010. Nesse caso foi feita uma subdivisão analisando as diversas dimensões da sua política externa para a África: 1) dimensão política; 2) dimensão cooperativa; 3) dimensão econômica. Dentro de cada uma dessas dimensões, também foram analisadas diferentes esferas de atuação. Para tanto, foi feita uma pesquisa bibliográfica além de pesquisa empírica, como a construção de um banco de dados referente ao comércio entre o Brasil e os países africanos; o levantamento de dados sobre os projetos de cooperação técnica,

\footnotetext{
${ }^{1}$ SILVA, Alberto da Costa e. Um rio chamado Atlântico. Rio de Janeiro: Nova Fronteira, 2011, p. 239.
} 
científica e educacional no período; informações sobre embaixadas, postos e visitas de Estado recíprocas; dados sobre os perdões de dívidas com países africanos; e sobre os investimentos brasileiros no continente africano. Foram usadas ferramentas de pesquisa de bancos de dados do Ministério de Desenvolvimento, Indústria e Comércio (MDIC), o Aliceweb; e do Banco Mundial, o World Integrated Trade Solution (Wits); da Agência Brasileira de Cooperação $(\mathrm{ABC})$; levantamento de dados de investimento do Banco Nacional de Desenvolvimento Econômico e Social (BNDES); foi pesquisada legislação interna do Ministério das Relações Exteriores (MRE) quanto a sua estrutura interna e sobre embaixadas. Por fim, foram feitas entrevistas em Brasília com agentes brasileiros responsáveis pela cooperação internacional na Agência Brasileira de Cooperação (ABC), Ministério da Saúde, Embrapa, Ministério das Relações Exteriores e Ministério da Educação.

O terceiro capítulo busca trazer o debate retórico sobre a importância das relações com África, especialmente no período Lula, colocando lado a lado editoriais dos principais jornais brasileiros e os discursos e pronunciamentos do então presidente Lula sobre África.

Parte-se do pressuposto que para analisar as relações externas Brasil-África em toda sua complexidade era preciso empreender um olhar interdisciplinar com um enfoque empírico. Essa escolha se justifica pelo debate suscitado, o que incorpora várias concepções ideológicas, revelando várias formas que a questão é vista.

Essa dissertação trabalha com a ideia da Política Externa como política de Estado, e o foco no período Lula, tendo um capítulo à parte, mais aprofundado, ocorre em função de seu intenso e divulgado ativismo. O objetivo de realizar o questionamento proposto por José Honório Rodrigues, em que pese o outro contexto no qual foi feito, não consiste em dar uma resposta positiva ou negativa, mas trabalhar a conceituação de política externa africana, a fim de mostrar desafios e avaliar em que medida o governo conseguiu transformar o discurso em prática. Assim, esse trabalho pretende contribuir para o estudo das relações Brasil-África com uma visão mais criteriosa e pormenorizada das relações ao longo do tempo. 


\section{Capítulo 1: A Política externa Brasileira Para África No Século XX}

Este capítulo tem o objetivo de apresentar as relações externas entre Brasil e África em um período histórico mais amplo, buscando uma perspectiva diacrônica. Apesar de ser um recorte muito amplo, faz-se necessário também uma breve retomada dos antecedentes históricos dessas relações. Desse modo, o capítulo inicia-se com a análise dessas relações antes de 1961 e depois prossegue com o estudo, tomando como base os governos brasileiros a partir dessa data até o fim do governo Fernando Henrique. O governo Lula, pelo destaque ao continente africano na política externa, será analisado no capítulo 2.

\subsection{Relações Históricas Brasil-África}

Apesar da atenção recente, as relações entre o Brasil e o continente africano são muito antigas. Essa afirmação, conquanto óbvia, não deve ser ignorada, pois o intercâmbio de influências foi profundo. Assim, o início do contato foi iniciado dentro do âmbito da colonização portuguesa, quando o primeiro navio com africanos escravizados chega à costa da América portuguesa na década de 1530, e o fluxo aumenta a partir de meados do século $\mathrm{XVI}^{2}$. As ligações, amplamente baseadas no comércio de escravos, mas não somente, começam a se enfraquecer a partir de 1850, com a proibição do tráfico de escravos no Império brasileiro. Então, a África tem um gradual afastamento das atenções brasileiras, cujo foco passa à América e à Europa. Além do distanciamento geográfico, o continente africano é afastado também do imaginário das elites brasileiras, que procuram se afastar da imagem da escravidão e se aproximar de um modelo branco e europeu. Apenas no pós-Segunda Guerra, lentamente, a política brasileira demonstra um movimento de reaproximação, que é limitado ainda pelos vínculos ditos ancestrais com Portugal. O principal ponto de inflexão nessa política ocorre na década de 1960, já no contexto das independências das nações africanas. Uma nova política externa, formulada pelo então presidente Jânio Quadros, abriria o caminho para a retomada dos contatos com os países africanos. Entretanto, ainda incorreria em contradições, e o próprio desenrolar da história brasileira no período causaria recuos e hesitações ao longo do século XX com relação à África. A aproximação atinge seu ápice com

\footnotetext{
${ }^{2}$ MATTOSO, Kátia M. De Queirós. Ser Escravo no Brasil. São Paulo: Brasiliense, 2003, p.53.
} 
o governo Lula, cujos méritos são não de apenas retomar conceitos e iniciativas anteriores, mas também de aprofundá-los, aproveitando um favorável contexto internacional. Esta parte do trabalho discorrerá brevemente sobre alguns períodos de aproximação das margens do Atlântico.

\subsubsection{Período Colonial até Primeira República}

Desde o início da colonização portuguesa, os dois lados do Atlântico mantiveram “íntimas relações”, nas palavras de José Honório Rodrigues ${ }^{3}$. Não era pra menos: a partir de meados do século XVI, com o constante e gradativo aumento do fluxo de africanos escravizados para a colônia portuguesa na América, até 1850, o Brasil colonial e principalmente a costa ocidental da África empreenderiam largo intercâmbio comercial, cultural e étnico, para além da escravidão ${ }^{4}$.

Exatamente por isso não custa insistir que o contato brasileiro com o continente africano vem desde o século XVI, especificamente com parte da costa ocidental africana. $\mathrm{O}$ período colonial foi o de maior e mais profundo intercâmbio entre as partes, mas baseado fortemente na escravidão: estima-se que mais de 3,5 milhões de africanos tenham sido trazidos compulsoriamente para o outro lado do oceano ${ }^{5}$, vindos principalmente do que se chamava a Costa dos Escravos, que vai do que hoje é Togo até a Nigéria, mas também Angola e Moçambique. No século XIX, a principal origem dos escravizados trazidos ao Brasil, como podemos observar no mapa abaixo, foi Angola, e menor participação de Moçambique, Senegâmbia, Serra Leoa, Costa do Ouro (Gana), Benin, e Biafra (Nigéria).

\footnotetext{
${ }^{3}$ RODRIGUES, op. cit., p. 31.

${ }^{4}$ MATTOSO, op. cit., p. 28-31; e SILVA, Alberto da Costa e. Um Rio Chamado Atlântico: a África no Brasil e o Brasil na África. Rio de janeiro: Nova Fronteira, 2011, p. 72.

${ }^{5}$ MATTOSO, op. cit., p. 53.
} 
Mapa 1 - Regiões de origem dos escravizados levados ao Brasil, 1800-1850

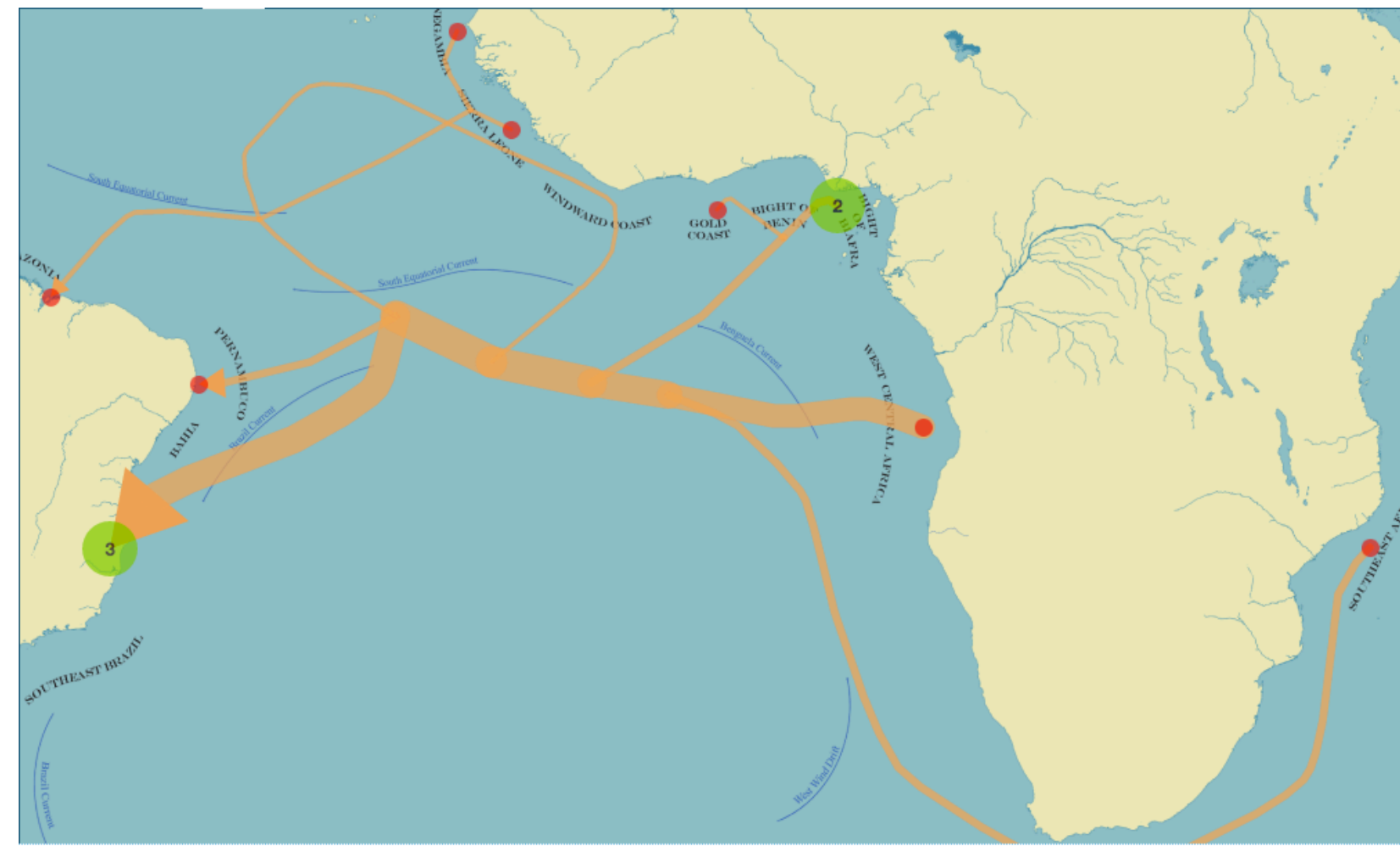

Fonte: Elaboração própria a partir de pesquisa em http://www.slavevoyages.org/assessment/estimates

Considerando apenas o século XIX, de 1800 até o fim do tráfico em 1850, entraram no Brasil mais de 2 milhões de africanos escravizados, segundo o banco de dados Trans-Atlantic Slave Database ${ }^{6}$. Neste período, a participação do Brasil no tráfico internacional era de cerca de $60 \%$, chegando a $87 \%$ na década de 1840 , conforme a tabela abaixo. O Brasil foi, com larga folga, o principal destino do tráfico negreiro.

Tabela 1 - Principais destinos e número de escravizados

\begin{tabular}{|l|r|l|l|l|l|l|l|l|}
\hline & $\begin{array}{l}\text { Am. do } \\
\text { Norte }\end{array}$ & $\begin{array}{l}\text { Caribe } \\
\text { Brit. }\end{array}$ & $\begin{array}{l}\text { Caribe } \\
\text { Franc. }\end{array}$ & $\begin{array}{l}\text { Am. } \\
\text { Hol. }\end{array}$ & $\begin{array}{l}\text { Am. } \\
\text { Esp. }\end{array}$ & Brasil & Totais & $\begin{array}{l}\text { Brasil } \\
\%\end{array}$ \\
\hline $\begin{array}{l}1791- \\
1800\end{array}$ & 480 & 36.452 & 3.267 & 3.127 & 4.591 & 25.403 & 76.921 & 33,0 \\
\hline $\begin{array}{l}1801- \\
1810\end{array}$ & 72.978 & 177.440 & 17.523 & 21.012 & 76.930 & 341.149 & 721.217 & 47,3 \\
\hline $\begin{array}{l}1811- \\
1820\end{array}$ & 4.635 & 5.983 & 21.604 & 812 & 116.779 & 451.078 & 600.891 & 75,1 \\
\hline
\end{tabular}

6 Pesquisa feita no projeto Trans-Atlantic Slave Trade Database. Disponível em : http://www.slavevoyages.org/assessment/estimates. Acesso em: 15 de junho de 2016. 


\begin{tabular}{|l|r|r|r|r|r|r|r|r|}
\hline $\begin{array}{l}1821- \\
1830\end{array}$ & 91 & 1.356 & 46.497 & 3.532 & 142.448 & 524.300 & 726.006 & 72,2 \\
\hline $\begin{array}{l}1831- \\
1840\end{array}$ & 0 & 9.166 & 774 & 0 & 197.148 & 338.182 & 545.547 & 62,0 \\
\hline $1841-$ & 0 & 507 & 0 & 0 & 55.252 & 400.016 & 455.775 & 87,8 \\
1850 & & & & & & & & \\
\hline $\begin{array}{l}1851- \\
1860\end{array}$ & 413 & 0 & 0 & 0 & 126.823 & 6.899 & 134.135 & 5,1 \\
\hline $\begin{array}{l}1861- \\
1870\end{array}$ & 0 & 0 & 0 & 0 & 37.124 & 0 & 37.124 & 0,0 \\
\hline Totais & 78.597 & 230.904 & 89.665 & 28.483 & 757.095 & 2.087 .027 & 3.297 .616 & 63,3 \\
\hline
\end{tabular}

Fonte: Elaboração própria a partir de pesquisa em http://www.slavevoyages.org/assessment/estimates

O "trato dos viventes", então, foi o condutor da economia colonial e a formação brasileira foi construída em cima de um sistema de exploração colonial unificado, tendo, de um lado, espaços de produção baseados no trabalho escravo, e, do outro, áreas fornecedoras dos escravos ${ }^{7}$. Conforme esse sistema se fortalece, mais importante tornam-se os territórios fornecedores de braço escravo. E pela proximidade e maior facilidade de contato, os entrepostos portugueses na África são melhor controlados desde a América portuguesa. José Honório Rodrigues coloca diretamente que Angola, como os outros estabelecimentos portugueses no Golfo da Guiné, era uma dependência brasileira, subordinada aos seus interesses escravagistas ${ }^{8}$. Vê-se, desse modo, a importância de Angola no período das invasões holandesas, em meados do século XVII. Os holandeses, instalados em Recife, enviam expedição a Angola para assegurar um maior fluxo de escravos para suas instalações açucareiras no nordeste colonial, ao mesmo tempo que infligem duro golpe no tráfico para a América portuguesa, pois então Angola era a principal fonte de mão de obra.

Em 1648, antes mesmo da própria insurreição pernambucana que expulsaria os holandeses do nordeste brasileiro em 1654, uma frota de 15 navios e 1.400 homens parte do porto do Rio de Janeiro para a libertação de Angola. Ainda segundo José Honório Rodrigues, desde então a vida de Angola depende mais do Brasil, tanto que os próximos governadores saíram da América portuguesa, e não da Metrópole ${ }^{9}$. Nos séculos XVII e XVIII, portanto, a costa ocidental africana, assim como o comando das fortalezas, ficava subordinada aos

\footnotetext{
${ }^{7}$ ALENCASTRO, Luiz Felipe de. O trato dos viventes: formação do Brasil no Atlântico Sul. São Paulo: Cia. Das Letras, 2000, p. 41-42.

${ }^{8}$ RODRIGUES, op. cit., p. 45.

${ }^{9}$ Ibid., p. 50.
} 
interesses brasileiros, o que leva Jaime Cortesão, em estudo sobre a formação das bandeiras, a afirmar que Angola foi, nesse período, uma província portuguesa do Brasil ${ }^{10}$.

O intercâmbio comercial, apesar de baseado na escravidão, tinha na pauta tabaco, ouro, açúcar e cachaça, todos usados como moeda de troca por escravos, e também, em menor escala, sal, tecidos e especiarias asiáticas ${ }^{11}$. No século XVIII, diante da decadência portuguesa no comércio, os colonos brasileiros tomam à frente do intercâmbio ao estabelecer e controlar uma rede direta com a Costa da Mina e Angola, passando antes pela Índia, e sem passar por Lisboa. Os próprios portugueses perceberiam que seus domínios na América haviam absorvido para si o comércio e navegação na costa africana, excluindo a metrópole. O Brasil era o ponto central de um comércio triangular: navios vindos da Ásia desembarcavam no Brasil, deixando mercadorias que seriam levadas à África para a compra de escravos com destino à América. Assim, nota-se que o comércio com navios estrangeiros era proibido na colônia, o que não era observado. Chegavam ao Brasil tecidos orientais de algodão, seda, damasco, tapetes, pimenta, além dos africanos escravizados de Angola, Mina, Bissau; do Brasil saía cachaça, farinha, mandioca, tabaco e carne seca ${ }^{12}$.

Cabe notar também a influência africana na formação brasileira, para além do comércio: os africanos trouxeram técnicas agrícolas e a pecuária, além de conhecimentos de tratamento de enfermidades tropicais, o que iam além do conhecimento português. Além disso, também contribuíram com técnicas de fundição de metais e de produção de utensílios ${ }^{13}$. Ainda, pelo contato por meio do comércio, a troca de informações era constante. Costa e Silva nos informa que o que se passava na África Atlântica repercutia no Brasil e vice-versa: os cativos, os marinheiros, ex-escravos e mercadores levavam notícias do Brasil para a África ${ }^{14}$.

No começo do século XIX, já com a Inglaterra expandindo seus domínios no contexto de seu ciclo de hegemonia, tanto o comércio de produtos quanto o tráfico negreiro, entre Brasil e África, expandia-se. A economia cafeeira, que inicia seu crescimento, também vai depender do braço escravo para se desenvolver. O quadro aprofunda-se com a vinda da família real em 1808 e a abertura dos portos, que consolida o crescimento do tráfico. Com a

\footnotetext{
${ }^{10}$ A Manhã. "Angola e a Formação do Bandeirismo". Rio de Janeiro, 15 de Agosto de 1948, pp. 4 e 8. Citado também por RODRIGUES, op. cit., p. 52.

${ }^{11}$ MATTOSO, op. cit., p. 29.

${ }^{12}$ RODRIGUES, op. cit., p. 55-57.

${ }^{13}$ PEREIRA, Analúcia Danilevicz et alli. História da África e dos Africanos. Petrópolis: Vozes, 2014, p. 189.

${ }^{14}$ SILVA, op. cit., p. 55.
} 
instalação da monarquia no Rio de Janeiro e posteriormente a elevação à Reino, em 1815, todo o comércio e navegação passam pela capital, tornando-a um centro do comércio intercontinental afro-asiático ${ }^{15}$.

Entretanto, nesse cenário, a influência britânica sobre Portugal - e, consequentemente, sobre a colônia e posteriormente sobre o Brasil independente - aumenta consideravelmente. Em 1810, Portugal celebra com a Grã-Bretanha os tratados de Aliança e Amizade, e de Comércio e Navegação, pelos quais Portugal cede diversos privilégios aos ingleses na área comercial, como, por exemplo, a taxa preferencial de produtos ingleses na colônia e a permissão de comércio com as possessões portuguesas na África, bem como o compromisso de estabelecer a gradual abolição do tráfico negreiro. Assim, a Grã-Bretanha passaria a pressionar Portugal ${ }^{16}$ e depois o Império Brasileiro para impedir o tráfico de escravos, por interesses econômicos travestidos de argumentos humanitários, em um momento de maior demanda por braços escravos. Na negociação para o reconhecimento da independência brasileira, a Inglaterra consegue que o Império brasileiro firme o tratado de 1826, renovando as obrigações contidas nos tratados de 1810 para a regulamentação e abolição do comércio de escravos, que deveria ocorrer a partir de 3 anos. Ratificado o tratado em 1830 e tornado lei a abolição do comércio negreiro em 1831, entretanto, o comércio humano continuaria, à revelia de tratados internacionais, até meados do século XIX. Apesar de em um momento o comércio ter sido combatido, logo a lei se tornaria letra morta, até a promulgação da lei Eusébio de Queiroz $^{17}$.

As ligações entre o Brasil recém independente e a costa ocidental africana podem também ser observadas quando do reconhecimento da independência brasileira. Como aponta Alberto da Costa e Silva, embaixadores foram enviados pelos reinos de Benim e Lagos, em 1824, para oficiar o reconhecimento da independência, sendo assim os primeiros soberanos a reconhecerem a independência brasileira: esta notícia causou alvoroço em Angola, onde surgiram movimentos favoráveis à união com o Brasil. Pouco antes da independência, dos 3 deputados angolanos eleitos para as Cortes Gerais portuguesas em 1822, dois deles

\footnotetext{
${ }^{15}$ RODRIGUES, op. cit., p. 146.

${ }^{16}$ Apesar de já ter ocorrido a independência, boa parte do comércio de escravos para o Brasil continuava a ser feito sob bandeira portuguesa, e os territórios portugueses na África continuaram a ser os maiores fornecedores de escravos para o Brasil. Bethell, 2002, p. 17.

${ }^{17}$ BETHELL, Leslie. A abolição do comércio brasileiro de escravos. Brasília: Senado Federal, 2002, p. 83 e 109.
} 
permaneceram no Brasil em apoio ao movimento. O receio metropolitano a essa união, mais tarde, teria reflexo no Tratado de reconhecimento da independência assinado em 1825 e com mediação britânica. Segundo cláusula do tratado, o Brasil não deveria receber propostas de união por colônias portuguesas. Ponto curioso, também citado por Silva, correu inclusive o boato de que o famoso Francisco Félix de Souza, conhecido como Chachá e braço direito do rei de Daomé, teria oferecido ao Brasil o protetorado da fortaleza de São João Batista de Ajudá, importante entreposto escravista ${ }^{18}$. A Inglaterra também temia a possível união com Angola, pois facilitaria o tráfico, visto que Angola era um dos maiores fornecedores de escravos $^{19}$.

Após a independência, a Inglaterra aumenta a pressão em torno do tráfico, a fim de, entre outros motivos, diminuir a concorrência brasileira no mercado açucareiro, frente à sua própria produção no Caribe. Com a renovação do tratado de 1817, pela Convenção de 1827, a Inglaterra renovava a pressão, e recebia o direito de apresamento de navios negreiros no Atlântico - que seria reforçado com o Bill Aberdeen, de 1845 - o que seria duro golpe aos interesses escravagistas brasileiros ${ }^{20}$. As dificuldades impostas pelos britânicos não extinguiriam o tráfico por si só, que continuou ocorrendo, porém com contínuo aumento dos preços, tendo em vista o custo do comércio frente ao novo risco. O custo do trabalho escravo aumentou no Brasil tanto quanto, consequentemente, a dívida com os negreiros, desviando recursos para as necessidades da nova expansão econômica no Brasil. Nesse cenário, Eusébio de Queiroz, em 1850, consegue aprovação no Parlamento da lei que ficaria conhecida com seu nome, pela qual o tráfico ficaria proibido $^{21}$ : esta lei surtiria efeito com a gradual diminuição da entrada de escravos nos anos seguintes. Em 1855 houve um desembarque de escravos em Serinhaém, Pernambuco, mas prontamente reprimido pelas autoridades. Em 1856, a última tentativa, entre Espírito Santo e Bahia, foi frustrada pelas autoridades, que já esperavam o negreiro ${ }^{22}$. Outro efeito, entretanto, seria o deslocamento dos interesses brasileiros da África para a bacia do Prata, num movimento de regionalização da política externa brasileira. José Honório Rodrigues o coloca como “a retirada da África [do Brasil]”, processo pelo qual rompe-se uma tradição de três séculos de contatos, e as poucas relações

\footnotetext{
${ }^{18}$ SILVA, op. cit., p. 11-13.

${ }^{19}$ BETHELL, op. cit., p 73.

${ }^{20}$ SILVA, op. cit., p. 16.

${ }^{21}$ SILVA, op. cit., p. 26.

${ }^{22}$ BETHELL, op. cit., p. 420-422.
} 
comerciais que persistem, entre Lagos e Bahia (relações estas que os ingleses objetivavam acabar junto com o tráfico), o retorno de ex-escravos e o estabelecimento de comunidades afro-brasileiras na África não são suficientes para esconder o afastamento ${ }^{23}$.

Rodrigues desenvolve um ponto interessante a partir desse deslocamento das relações brasileiras: segundo ele, pesquisando jornais e atas da época, distinguia-se o africano do escravo, e recriminava-se a vinda de escravos. Após 25 anos de política britânica contra o tráfico, entretanto, fora fortalecido o preconceito que identifica o africano apenas como escravo. Bethell identifica esse preconceito como o "medo da africanização", no qual cria-se o contínuo aumento da população negra degradava o país ${ }^{24}$. Essa visão, digamos, europeizada e ocidentalizada, buscará o modelo da civilização europeia. Rodrigues contrapõe a isso uma afirmação de Bernardo Pereira de Vasconcelos de que a África civiliza o Brasil ${ }^{25}$. Entretanto, deve-se notar que o discurso de Vasconcelos no Senado brasileiro em 1843 não tem esse sentido colocado por Rodrigues ${ }^{26}$, pois entra no contexto da defesa do comércio de escravos empreendida pelo senador. Em outro discurso, também defendendo o tráfico negreiro, Vasconcelos afirmou que a civilização brasileira provinha da África, pois foram os escravos que proporcionaram as riquezas do Brasil. Assim, de um modo torto, ele professava os efeitos benéficos da escravidão para a formação do Brasil ${ }^{27}$. O medo da africanização, desse modo, será a visão predominante no século por vir, e que, mais tarde, Rodrigues iria chamar de "complexo de caiação" 28 , um dos obstáculos de uma política externa mais voltada para a África.

A política brasileira, no início do século $\mathrm{XX}$, concentrava suas forças no estreitamento das relações com a Europa e a América. Neste caso, a política externa brasileira concentravase, por meio da figura do Barão de Rio Branco, na consolidação de suas fronteiras. As relações com a África eram escassas: em 1923 o Brasil reconheceria a independência do Egito e em 1925 firmaria um acordo de resolução de controvérsias com a Libéria. A partir de então, com a alta do preço do café, cujo mercado o Brasil amplamente dominava, a África, por meio

\footnotetext{
${ }^{23}$ RODRIGUES, op. cit., p. 229.

${ }^{24}$ BETHELL, op. cit., p. 95.

${ }^{25}$ RODRIGUES, op. cit., p. 14 e 230.

${ }^{26}$ Vasconcelos diz: “(...) a África tem civilizado a América; (...) veja os outros todos que devem sua existência, o seu aperfeiçoamento aos países que têm procurado em parte africanizar-se”. Carvalho, 1999, p. 268-269.

${ }^{27}$ LIMA, Manuel de Oliveira. O império brasileiro: 1822-1889. Brasília: Ed. UnB, 1986, p. 123; MARQUESE, Rafael de Bivar e PARRON, Tâmis. Azeredo Coutinho, Visconde de Araruama e a Memória de Escravos de 1838. In: Revista de História, n. 152, 2005, p. 100.

${ }^{28}$ RODRIGUES, op. cit., p. 112.
} 
de alguns países, inicia a plantação cafeeira e inaugura a concorrência com o Brasil, já existente em outros mercados agrícolas como do algodão (Uganda) e do cacau (Gana, então Costa do Ouro, e Nigéria) ${ }^{29}$.

Após a Revolução de 1930, o Brasil iria realizar um acordo com a Inglaterra, pelo qual estenderia às colônias inglesas na África a reciprocidade comercial acordada com os ingleses. Mas o comércio com o continente africano não representaria, nesta década, mais do que $3 \%$ do comércio exterior brasileiro ${ }^{30}$. Já na Segunda Guerra Mundial, surgiria renovado interesse brasileiro na África Setentrional por motivos estratégicos - proximidade do nordeste brasileiro com o norte africano -, na possibilidade de cooperação brasileira no cenário africano da guerra, e depois na participação brasileira no teatro europeu da guerra. Após o conflito, novo desinteresse, justamente no período em que se iniciam os movimentos de independências das colônias africanas. A preocupação brasileira, na década de 1950, se dá apenas pela potencial concorrência africana nos mercados de produtos primários. O presidente Kubitschek, em cujo governo explodem as independências africanas, mantém a preocupação na América Latina com a Operação Pan-Americana (OPA), e reconhece a soberania dos novos Estados ${ }^{31}$, não indo além desse ato de apoio. Contraditoriamente, nada é feito em apoio às colônias portuguesas na África. Pelo contrário, o comportamento brasileiro na ONU chega a acompanhar as votações de Portugal e França em questões coloniais. Rodrigues chama a política externa de Kubitschek de "malogro", pois não soube atuar no momento certo em relação aos novos países africanos ${ }^{32}$.

\subsubsection{Governo Jânio Quadros e João Goulart (1961-1964)}

“O nosso esforço em África, por mais intenso que venha a ser, não poderá senão constituir uma modesta retribuição, um pequeno pagamento da imensa dívida que o Brasil tem para com o povo africano. Essa razão, de

\footnotetext{
${ }^{29}$ Ibid., p. 237-238.

${ }^{30}$ Ibid., p. 239.

${ }^{31}$ Em 1956, oito países já eram independentes: República Árabe Unida (união de Egito e Síria), Etiópia, União Sul-Africana (África do Sul), Líbia, Marrocos, Tunísia e Sudão; em 1960, o "Ano da África”, tornam-se independentes Camarões, Togo, Madagascar, Congo Belga, Somália, Alto Volta (Burkina Faso), Costa do Marfim, Daomé (Benim), Níger, República Centro-Africana, Chad, Gabão, Congo, Nigéria, Mali e Mauritânia. (Rodrigues, 1982, p. 244)

32 RODRIGUES, op. cit., p. 245.
} 
ordem moral, justificaria por si só a importância que este governo empresta à sua política de aproximação com a África” (Jânio Quadros, Mensagem ao Congresso Nacional, $1961^{33}$ )

José Honório Rodrigues não deixa de criticar a política externa de Juscelino Kubitschek, que não teria sabido agir durante a "Primavera africana"34. José Humberto Brito Cruz também aponta nessa direção, colocando a diplomacia de Kubitschek como "tímida", cuja maior ação frente à conjuntura internacional foi a elaboração da Operação Pan-americana (OPA), que na verdade não agiu fora do campo do alinhamento aos Estados Unidos, apresentando um plano de ações aos norte-americanos para manter seus interesses no hemisfério $^{35}$. Em oposição a Kubitschek, conforme Rodrigues, a política externa de Jânio Quadros sugeriria uma "reviravolta"36. A citação que abre este subcapítulo, retirada da Mensagem Presidencial ao Congresso Nacional, de 20 de março de 1961, mostra explicitamente a mudança de rumos na formulação da política externa para a África, em conjunto com um discurso que remonta ao passado histórico entre o Brasil e o continente africano. O novo contato estaria, nos discursos presidenciais e do chanceler Afonso Arinos, sempre ligado às ligações étnicas e históricas entre brasileiros e africanos e à noção de que o Brasil representava uma "perfeita democracia racial" ${ }^{37}$. A essa nova política externa convencionou-se chamá-la de "Política Externa Independente" ou "PEI", que perpassaria os governos de Jânio Quadros e João Goulart e pelos chanceleres Afonso Arinos, Francisco Clementino de San Tiago Dantas e João Augusto de Araújo Castro. Porém, essa não foi um bloco homogêneo, e recebeu contribuições de todos esses chanceleres. Essa subseção buscará explicitar as mudanças em relação à África nesse período.

Paulo Fagundes Visentini entende que a PEI foi uma continuação do nacionalismo de governos anteriores, com mesmos objetivos internos e externos, mas adaptada a uma nova

\footnotetext{
${ }^{33}$ Franco, Álvares da Costa (org.). Documentos da Política Externa Independente, vol. 1. Brasília: FUNAG, 2007, p. 55.

${ }^{34}$ RODRIGUES, op. cit., p. 398.

${ }^{35}$ CRUZ, José Humberto de Brito. Aspectos da Evolução da Diplomacia Brasileira no Período da Política Externa Independente. In: Danese, Sérgio França (org.). Ensaios de História Diplomática do Brasil (19301986). Cadernos do IPRI, n.2, Brasília: FUNAG, 1989, p. 47.

${ }^{36}$ RODRIGUES, op. cit., p. 401.

37 "Além disso, os processos de miscigenação com que a metrópole portuguesa nos plasmou facilitaram a nossa democracia racial, que, se não é perfeita como desejaríamos, é, contudo, a mais avançada do mundo." Discurso de posse do ministro das Relações Exteriores, Afonso Arino de Melo Franco, fevereiro de 1961. FRANCO, op. cit., p. 35 .
} 
situação doméstica e mundial ${ }^{38}$. Na mesma linha, Clodoaldo Bueno enxerga a formação da PEI num quadro de ideias do que chama de "nacional-desenvolvimentismo-populista". Entretanto, a política exterior ia além da formulada pelo governo anterior, que priorizava o contexto hemisférico. É evidente que mesmo durante o governo Kubitschek havia o desejo de maior participação brasileira no cenário internacional, mas esta passaria antes pelo alinhamento americano. A PEI, além de ampliar a política externa geograficamente, problematizou as relações Norte-Sul ${ }^{39}$. Ambos momentos estão dentro da conjuntura da Revolução Cubana: enquanto Kubitschek formula a OPA, vinculando os interesses brasileiros aos dos Estados Unidos, a PEI aproveita o contexto a fim de buscar vantagens dentro da polarização da Guerra Fria. No mesmo sentido, Cruz enxerga a PEI como uma ilha entre dois períodos de conservadorismo diplomático ${ }^{40}$.

A denominação de "Política Externa Independente" para a formulação da política externa do período de 1961 a 1964 deu-se posteriormente à elaboração de suas diretrizes principais, postas por Jânio Quadros e Afonso Arinos de Melo Franco. Por essa denominação, pode-se ter a impressão que o período tenha mantido uma continuidade, mas na realidade é possível enxergá-lo em 3 diferentes fases, conforme divisão sugerida por José Humberto de Brito Cruz. A primeira relaciona-se com o curto período de Jânio Quadros e de seu chanceler Afonso Arinos: a diplomacia brasileira aqui estaria no campo do neutralismo, apesar dela não o reconhecer, pois não queria participar de um movimento - no caso, o Movimento dos Não Alinhados -, no qual não teria uma liderança nítida e os interesses brasileiros perderiam-se em meio às reivindicações afro-asiáticas ${ }^{41}$. A segunda fase, já com João Goulart na presidência, coincide com a chancelaria de San Tiago Dantas, que conforma uma continuidade à formulação da política externa, ao mesmo tempo que lhe consolida os princípios fundamentais - inclusive dando-lhe o conhecido epíteto de "Política Externa Independente", por meio de seu livro de mesmo nome, no qual sistematiza a política

\footnotetext{
${ }^{38}$ VISENTINI, Paulo Fagundes. Relações Exteriores do Brasil II (1930-1964): o nacionalismo, da Era Vargas à Política Externa Independente. Petrópolis: Vozes, 2009, p. 141.

${ }^{39}$ CERVO, Amado L. e BUENO, Clodoaldo. História da Política Exterior do Brasil. $3^{\text {a }}$ Edição. Brasília: Ed. UNB, 2008, p. 309-310.

${ }^{40}$ CRUZ, op. cit., p. 54.

${ }^{41}$ Ibid., p. 50; “(...) a atitude brasileira não era nem de neutralidade, nem de neutralismo, mas de independência no tocante à execução dos seus compromissos. Não somos neutralistas porque temos uma posição tomada em face do conflito comunismo-democracia”. Exposição do Ministro Afonso Arinos na Câmara dos Deputados. Julho de 1961. FRANCO, op. cit., p. 135
} 
exterior $^{42}$. Nesse período, apesar da consolidação da PEI, internamente o Brasil sofre gradativa polarização ideológica, o que dificultaria o próprio governo. A terceira fase coincide com a chancelaria de João Augusto de Araújo Castro. Já no cenário do entendimento entre as superpotências, Araújo Castro abandona o quadro de referência da Guerra-Fria ${ }^{43}$ e consegue levar a política externa mais adiante, abandonando o tom neutralista de outrora e colocando o desenvolvimento como leitmotiv da diplomacia brasileira, também sob os auspícios da $1^{\mathrm{a}}$ Unctad e dos princípios da Cepal. Amado Cervo e Clodoaldo Bueno colocam como principais fundamentos da PEI a mundialização das relações internacionais do Brasil; atuação isenta de compromissos ideológicos - apesar da profissão de fé em relação ao mundo ocidental -; ênfase na bipolaridade entre Norte e Sul, e não Leste-Oeste; busca da ampliação das relações comerciais brasileiras; intenção de maior participação nas decisões internacionais; luta pelo desenvolvimento, paz e desarmamento; posição contrária a experimentos nucleares; defesa da autodeterminação dos povos e não-intervenção ${ }^{44}$.

Paulo Visentini, por outro lado, logra colocar os princípios da PEI no quadro do desenvolvimentismo brasileiro. Observa que o então presidente Jânio Quadros tinha consciência do crescimento econômico e industrial brasileiro, e que buscava, com a política externa, incrementar a exportação de primários, a fim de gerar divisas para a crescente industrialização, que tinha a necessidade de importar bens de capital e de tecnologia. Assim, Visentini, a partir das declarações de Jânio Quadros, afirma que a estratégia da PEI é aumentar as exportações primárias para países industrializados, importando deles técnicas e bens de capital, ao mesmo tempo que expande as exportações manufaturadas brasileiras para o recém independente mundo afro-asiático ${ }^{45}$. O autor, desse modo, coloca a PEI como uma política externa para o desenvolvimento nacional, na esteira das palavras de San Tiago Dantas: "Na origem de cada atitude, na fixação de cada linha de conduta, estava presente uma constante: a consideração exclusiva do interesse do Brasil, visto como um país que aspira (I) ao desenvolvimento e à emancipação econômica (...)" ${ }^{\text {,46. }}$.

Como diz San Tiago Dantas no prefácio de seu livro, a PEI não foi “concebida como doutrina ou projetada como plano antes de vertida para a realidade. Os fatos precederam as

\footnotetext{
${ }^{42}$ DANTAS, Francisco Clementino de San Tiago. Política Externa Independente. Brasília: FUNAG, 2011.

${ }^{43}$ CRUZ, op. cit., p. 52.

${ }^{44}$ CERVO e BUENO, op. cit., p. 311-312.

${ }^{45}$ VISENTINI, op. cit., p. 134-135.

${ }^{46}$ DANTAS, op. cit., p. 9.
} 
ideias." ${ }^{47}$. Quanto ao aspecto africano dessa política, talvez não seja arriscado dizer que aqueles fatos estejam relacionados à "Primavera africana", nas palavras de José Honório Rodrigues. Ou, ainda, a PEI é resultado da leitura de um contexto internacional que se desenrolava desde meados da década de 1950 e precisava ser assimilado o quanto antes pelo Brasil. É interessante notar que Jânio percebeu o momento de ação já durante a campanha presidencial, evitando assim pensar que sua política externa, mais ousada que a interna, seria apenas resultado de sua "enigmática" ou "histriônica" personalidade. Rodrigues ${ }^{48} \mathrm{faz}$ referência a esse momento, no qual Quadros já delineia sua percepção de política externa.

Em 12 de maio de 1960, em encontro com o Partido Republicano, o candidato presidencial afirma que o Brasil "não pode continuar na posição tímida em que se encontra". Caso eleito "fará questão de manter relações diplomáticas" com os países africanos e asiáticos, pois além das vantagens econômicas, essas relações podem aumentar a autoridade do país, que deve manter relações com todos os países, desde que haja interesse nacional ${ }^{49}$. Ainda em maio de 1960, também em reportagem ao jornal $O$ Globo, Quadros prega pela atualização da diplomacia brasileira, a qual classifica de "vitoriana", e realizadora de uma política "de ritmos e rimas parnasianas", num mundo de "teleguiados, foguetes e satélites, de negócios e definições precisas". É interessante notar que o contexto das reuniões de Bandung e Belgrado, do surgimento do Movimento dos Não Alinhados está presente na discussão sobre a política externa na opinião pública. Perguntado pelo jornal se o Brasil deveria participar dessas reuniões, Quadros responde que sim, pois acreditava, segundo seus argumentos, caber ao Brasil posição de destaque, ao considerar as características econômicas e raciais brasileiras, bem como os novos países do mundo afro-asiáticos deveriam encontrar no Brasil apoio na luta pela emancipação ${ }^{50}$. Apesar das críticas à diplomacia, havia diplomatas conscientes desse contexto. Um exemplo é o diplomata Adolpho Justo Bezerra de Menezes, que foi o enviado brasileiro na Conferência de Bandung, em 1955. No seu entender, se há um bloco ao qual o Brasil possa pertencer, este é o dos subdesenvolvidos. O processo

\footnotetext{
${ }^{47}$ Ibid., p. 9.

${ }^{48}$ RODRIGUES, op. cit., p. 399-400.

${ }^{49}$ O Globo, Rio de Janeiro, 12 de março de 1960, "Reuniu-se o PR para ouvir Jânio Quadros", p. 6.

${ }^{50}$ O Globo, Rio de Janeiro, 31 de março de 1960, “Jânio prega a Atualização da Política Externa”, p. 7.
} 
que ocorre no final dos anos 50 e início dos 60 é um marco de libertação política, de busca da independência econômica do continente africano ${ }^{51}$.

“Creio que é precisamente na África que o Brasil pode prestar o melhor serviço aos conceitos de vida e métodos políticos ocidentais. Nosso país deveria tornar-se o elo, a ponte entre a África e o Ocidente (...)". Em seu famoso artigo publicado na Revista Foreign Affairs, já após sua renúncia, Quadros demonstrava a coerência no seu discurso em relação à África. Quando eleito, não demorou muito a colocar em prática a ideia de que a África "representa hoje uma nova dimensão da política brasileira" 52 . E agia por meio de seus conhecidos bilhetes, cuja compilação foi feita pelo Centro de História e Documentação Diplomática (CHDD). Uma análise dos bilhetes enviados ao Ministério das Relações Exteriores nos dá uma quadro da participação do presidente na política externa à África ${ }^{53}$. Dos diversos comunicados, pelo menos dezoito deles se referem à política para o continente africano, desde o primeiro no dia 23 de fevereiro de 1961 até 23 de agosto do mesmo ano, dias antes da renúncia.

Um dos primeiros bilhetes, também citado por Rodrigues, datado de 23 de fevereiro, já solicita ao MRE a constituição de um grupo de trabalho para preparar a representação brasileira nos novos países africanos, bem como a formulação da política brasileira para o continente, abarcando aspectos políticos, econômicos e culturais. Já em março daquele ano, o chanceler Afonso Arinos leva a Quadros um relatório, no qual reafirma a importância brasileira de servir de ponte entre o continente africano e o ocidente: "não somos nós que buscamos a África; as jovens nações deste continente é que buscam o Brasil”, afirmação esta tomada com muita desconfiança por Rodrigues ${ }^{54}$. Entretanto, segundo José Flávio Sombra Saraiva ${ }^{55}$, o grupo encarregado de elaborar o relatório acreditava com otimismo nas oportunidades que se abriam com as independências africanas e as possibilidades econômicas delas resultantes. Em 6 de abril, Quadros responde a esse relatório com as instruções de abertura de várias embaixadas na África, como em Senegal, Guiné (cumulativa a Mali),

\footnotetext{
${ }^{51}$ MENEZES, Adolpho Justo Bezerra de. Ásia, África e a Política Independente do Brasil. Rio de Janeiro: Zahar, 1961, p. 104.

${ }^{52}$ FRANCO, op. cit., p. 151.

${ }^{53}$ CENTRO DE HISTÓRIA E DOCUMENTAÇÃO DiPlomátiCA. Cadernos do CHDd. Ano V, n. 8. Brasília: Centro de História e Documentação Diplomática, FUNAG, 2006.

${ }^{54}$ RODRIGUES, op. cit., p. 403-404.

${ }^{55}$ SARAIVA, José Flávio Sombra. Do silêncio à afirmação: relações do Brasil com a África. In: Cervo, Amado Luiz (org.). O Desafio Internacional. Brasília: Ed. UnB, 1994, p. 292.
} 
Nigéria (cumulativa com Camarões), Costa do Marfim (cumulativa com Alto Volta (hoje Burkina Faso), Níger e Daomé (hoje Benim), Gana, Etiópia, além de consulados na Rodésia, Congo e Quênia. Num gesto de reciprocidade, as primeiras embaixadas africanas na América Latina seriam instaladas em Brasília, de Gana e Senegal, em $1962^{56}$.

Entretanto, apenas Senegal, Gana e Nigéria teriam instalações ainda em seu governo Quadros $^{57}$. A primeira embaixada brasileira na África subsaariana seria a de Acra, capital de Gana. O consulado de Dacar, capital de Senegal, foi transformado em embaixada. Os governos africanos responderam positivamente às iniciativas, enviando missões ao Brasil ${ }^{58}$. Às comemorações de independência foram enviados representantes, como o próprio chanceler e o deputado Coelho de Souza. Uma grande missão foi feita a bordo do navio-escola Custódio de Melo, numa "viagem de circum-navegação à África", produtos brasileiros que pudessem ser comercializados com a África, além de levar grande delegação de representantes da indústria e da imprensa. Cabe notar que o navio-escola tradicionalmente navegava por um circuito europeu com a nova turma de marinheiros ${ }^{60}$.

Quadros empreendeu também uma reforma no próprio Ministério das Relações Exteriores, em 1961, criando a Divisão de África, responsável exclusiva das relações com o continente africano, além de incluir no Relatório de Gestão do MRE um capítulo dedicado à África ${ }^{61}$. Outra importante iniciativa de Quadros foi a criação do Instituto Brasileiro de Estudos Afro-Asiáticos (IBEAA), com o objetivo de desenvolver estudos e projetos para acelerar o conhecimento mútuo e a aproximação brasileira aos novos países africanos ${ }^{62}$, prevendo também bolsas de estudos para estudantes africanos, intercâmbio de professores, exposições e seminários.

A abertura da embaixada em Acra, segundo Jerry Dávila, tinha o objetivo de aproximar o Brasil de um líder do movimento de independência ${ }^{63}$ : Gana foi uma das primeiras nações a garantir soberania na África subsaariana, graças à luta de Kwame Nkrumah, tornando-o um modelo para toda a África. Desse modo, já em abril, como

\footnotetext{
${ }^{56}$ LEITE, Patrícia Soares. Brasil e a Cooperação Sul-Sul em três momentos de Política Externa. Brasília: Funag, 2011, p. 99.

${ }^{57}$ VISENTINI, op. cit., p. 156.

${ }^{58}$ SARAIVA, op. cit., 292.

${ }^{59}$ CENTRO DE HISTÓRIA E DOCUMENTAÇÃO DIPLOMÁTICA, op. cit., p. 333 e 453.

${ }^{60}$ LEITE, op. cit., p. 100.

${ }^{61}$ Ibid., p. 98.

${ }^{62}$ VISENTINI, op. cit., p. 156.

${ }^{63}$ DÁVILA, Jerry. Hotel Trópico. São Paulo: Paz e Terra, 2012, p. 59.
} 
mencionado anteriormente, Quadros orienta o Itamaraty com relação à abertura da embaixada em Gana, e em 14 de abril, indica para funções de embaixador o seu adido de imprensa, Raymundo de Souza Dantas, para essa embaixada, além de Rubem Braga e Cícero Dias, para o Marrocos e Tunísia, respectivamente ${ }^{64}$. Souza Dantas, no entanto, só viajaria para Gana em setembro, após, portanto, a renúncia de Quadros. Ele seria, assim, o primeiro embaixador negro do Brasil, na primeira embaixada brasileira na África subsaariana.

Todavia, o que deveria ser uma experiência de aproximação, acabou sendo mais um episódio da série de equívocos da política africana de Quadros. Souza Dantas descreveria sua experiência como "uma missão de antemão condenada"65. Ele enfrentaria, em 2 anos no cargo, duas diferentes dificuldades: uma, a falta de apoio do próprio Itamaraty; a outra, a contradição da política externa brasileira em relação à África. A falta de apoio institucional já se desenhava quando da renúncia de Jânio Quadros, em agosto de 1961. Ademais, como não era diplomata de carreira, sofreu ainda mais por ter sido nomeado diretamente para o mais alto cargo da carreira diplomática. Conforme aponta Dávila, o funcionário do Ministério encarregado de organizar a embaixada em Acra, Sérgio Corrêa do Lago, queixou-se da nomeação ao Itamaraty, mostrando-se ofendido. Apesar de ser um dos diplomatas que acreditavam no papel do Brasil como elo entre a África e o mundo ocidental, ele recusou-se a deixar a residência da embaixada quando da chegada de Souza Dantas à capital de Gana, forçando o novo embaixador a residir em diversos diferentes hotéis por meses ${ }^{66}$. A segunda dificuldade pode ser exemplificada por um episódio narrado em seu livro de memórias. A abertura de embaixadas e nomeação de escritores como representantes tinha a intenção de apresentar o Brasil como a "democracia racial” dos discursos do presidente Quadros: tal ideia foi de fato propagada na África. E durante sua missão em Gana, Souza Dantas se deparou, em um encontro com estudantes, com a pergunta, certeira: "Não há discriminação racial no Brasil?”. Souza Dantas não soube responder, revelando a contradição entre a política e a realidade ${ }^{67}$.

Dávila, em seu livro Hotel Trópico, constrói o quadro dos intelectuais no momento da abertura diplomática de Quadros à África. Maria Yedda Linhares, em entrevista à Dávila,

\footnotetext{
${ }^{64}$ CENTRO DE HISTÓRIA E DOCUMENTAÇÃO DIPLOMÁTICA, op. cit., p. 358 e DÁVILA, op. cit., p. 59. ${ }^{65}$ SOUZA DANTAS, Raymundo. África Difícil: Missão Condenada. Rio de Janeiro: Editora Leitura, 1965, p. 21.

${ }^{66}$ DÁVILA, op. cit., p. 61 e SOUZA DANTAS, op. cit., p. 55.

${ }^{67}$ SOUZA DANTAS, op. cit., p. 39.
} 
sintetiza a sensação na época: “(...) a África era muito importante para nós, intelectuais, pessoas que nos julgávamos mais de esquerda. Tem de mudar a política, tem que se voltar para a África. O Brasil tem suas raízes na África" ${ }^{\text {"68 }}$. Linhares trabalhava junto a Cândido Mendes, outra importante figura nos estudos africanos, no IBEAA. Junto com outros intelectuais - como Eduardo Portella, Antonio Olinto, Rubem Braga e Pierre Verger Linhares e Mendes se envolviam com entusiasmo no desenvolvimento de políticas relacionadas com a África, vendo o potencial brasileiro para se atrelar na mudança mundial advinda da descolonização. Os centros de discussão ficavam no Rio de Janeiro, no IBEAA, e em Salvador, no Centro de Estudos Afro-Orientais, na Universidade da Bahia. Linhares, na entrevista a Dávila, em 2008, iria criticar todo esse entusiasmo, colocando-o como um idealismo não prático. Segundo ela, essa intelectualidade não era preparada e não sabia exatamente a proporção da África na política concreta brasileira; não tinham objetivos práticos. A África, enfim, era um símbolo da mudança no meio intelectual comprometido com medidas progressistas ${ }^{69}$.

Saraiva aponta corretamente que a política de Quadros se dirigia a quatro grandes áreas na África. A primeira seria a África setentrional, especialmente com relação ao Egito de Nasser. A segunda seria voltada a África subsaariana. Uma terceira seria referente à África do Sul e, por último, aos territórios portugueses na África. Em relação à segunda área, a política se concentrou na costa ocidental e atlântica, numa estratégia de negociação direta com os governos africanos. Essa diferenciação de áreas revela-se pertinente, pois em cada uma a política externa enfrentou diferentes obstáculos. No geral, a política externa africana gerava desconfiança no Congresso Nacional, principalmente junto ao partido de apoio do presidente, a União Democrática Nacional (UDN), caracterizada, na diplomacia, pela defesa da aproximação com os Estados Unidos. A cada novo gesto de aproximação à África, seus representantes temiam pela influência de correntes comunistas. Vale lembrar que o chanceler Afonso Arinos vinha da UDN, o que certamente ajudou a controlar ânimos mais exaltados com a nova diplomacia que se desenhava. Mesmo após a renúncia, já com o chanceler San Tiago Dantas, a política se desenvolveu, apesar dos conservadores da UDN no Congresso.

\footnotetext{
${ }^{68}$ DÁVILA, op. cit., p. 69.

${ }^{69}$ DÁVILA, op. cit., p. 71-81.
} 
Saraiva cita que um dos principais pilares da PEI, a descolonização, foi colocado como interesse nacional, após debate entre diplomatas e políticos ${ }^{70}$.

No caso da África do Sul, a PEI foi perceptivelmente ambígua. O regime do apartheid já se desenvolvia no país, e com as independências a partir da década de 1950, a própria pressão africana quanto ao regime segregacionista aumentava, também atingindo os países que insistiam em manter relações com o país, como era o caso brasileiro. Entretanto, apesar dos discursos presidenciais e diplomáticos contra o racismo e a pregação do Brasil como "a mais perfeita democracia racial do mundo", o Brasil abstinha-se de ações mais enérgicas contra o regime sul-africano, eclipsado pelas relações econômicas. Observa-se que no começo da década de 1960, a África do Sul se apresentava como o maior parceiro comercial africano do Brasil, sendo o destino de mais de $50 \%$ das exportações para o continente ${ }^{71}$. O ato mais evidente de condenação foi o apoio à resolução proposta pela Nigéria para a retirada da África do Sul da Organização Internacional do Trabalho, em junho de $1961^{72}$, podendo ser visto inclusive em um dos bilhetes de Quadros, no qual orienta a delegação brasileira a "votar com a Nigéria, condenando a política racial da África do Sul"73. Mais tarde, em novembro de 1961, na ocasião da Assembleia Geral da ONU, a Resolução 1.663 foi aprovada, condenando o regime de aparteísmo sul-africano, o que não provocou nenhuma mudança no comportamento daquele país. Um ano depois, a Assembleia Geral da ONU aprovou mais uma Resolução, a 1.761, condenando o país sul-africano e exortando os países membros da ONU a romperem relações diplomáticas e comerciais com ele. Neste caso, já após a renúncia de Quadros, o Brasil absteve-se na resolução, comportamento que se repetiria até a década de 1970, mantendo assim as relações diplomáticas e comerciais com a África do Sul. Essa posição é criticada por Rodrigues, contrariando discursos e princípios diplomáticos que indicavam o aumento das relações com os países africanos. Estes, por sua vez, observam muito bem a posição brasileira e cobram uma posição coerente, como ocorreria já na década de 1970, quando um grupo de países africanos coloca o Brasil numa lista de países

\footnotetext{
${ }^{70}$ SARAIVA, op. cit., p. 293-295.

${ }^{71}$ INSTITUTO BRASILEIRO DE GEOGRAFIA E ESTATÍSTICA. Anuário Estatístico do Brasil 1963, p. 165.

${ }^{72}$ RODRIGUES, op. cit., p. 327.

${ }^{73}$ CHDD, op. cit., p. 420.
} 
recomendados para receberem sanções econômicas pelo apoio a governos branco-minoritários na África ${ }^{74}$.

Quanto aos territórios portugueses na África, o comportamento brasileiro também foi inconstante. Em 1961, durante o período Quadros, os movimentos de libertação de Angola, MPLA e FNLA, se insurgiram contra o governo português, e exigiria alguma reação do governo brasileiro. Inicialmente, como aponta Saraiva ${ }^{75}$, o Brasil não tratou o colonialismo português como exceção dentro dos princípios da PEI, e assim o indicava nos discursos e pronunciamentos. Em meio às insurreições nos territórios portugueses, Afonso Arinos partiu em missão para Dacar, onde representaria o Brasil na posse de Léopold Senghor, e depois iria para Lisboa, encontrar-se com Salazar. Após o encontro, a condenação ao colonialismo português tornou-se mais suave. Segundo Afonso Arinos, o Brasil continuava a apoiar o anticolonialismo, mas respeitava a posição de Portugal no assunto, afirmando que opinar sobre Angola era intervir nos assuntos internos de Portugal, considerando tacitamente as colônias portuguesas como territórios ultramarinos portugueses.

Esse episódio específico mostra a influência do lobby português tanto na intelectualidade quanto na política brasileira, mais do que uma simples contradição da figura de Jânio Quadros. Podemos verificar a orientação anticolonialista justamente nesse caso em relação à Angola: na compilação de comunicações entre Quadros e o Itamaraty, verifica-se um memorando classificado com orientações a Afonso Arinos sobre a posição brasileira quanto ao colonialismo português, provavelmente no contexto das insurreições em Angola. Datado de 15 de março de 1961, Quadros coloca explicitamente: "Inteiramente de acordo com o ofício de Vossa Excelência. O Brasil não se ligará à política colonialista de Portugal, na África"76, fazendo referência, também, à viagem do chanceler à Lisboa, para esclarecer a posição brasileira na questão.

Mario Gibson Barboza, em seu livro de memórias ${ }^{77}$, oferece a visão da perspectiva do Itamaraty nesse episódio. Representante brasileiro na ONU em 1959 e 1960, tinha forte posição anticolonialista, enquanto que, ao contrário, a imprensa brasileira na época era em sua

\footnotetext{
${ }^{74}$ RODRIGUES, op. cit., p. 330-332 e 521.

${ }^{75}$ SARAIVA, op. cit., p. 298.

${ }^{76}$ CHDD, op. cit., p. 336.

${ }^{77}$ BARBOZA, Mario Gibson. Na Diplomacia, o traço todo da vida. Rio de Janeiro: Francisco Alves Editora, 2007.
} 
maioria pró-Portugal ${ }^{78}$. O interessante é sua observação de que essa imprensa defendia a noção de que o colonialismo português era diferente, pois benevolente, sem discriminação racial, sem violência - em linha com o lusotropicalismo de Gilberto Freyre da época. Freyre, ao longo dos anos 50 e 60 procurava valorizar o trópico, desenvolvendo as ideias de lusotropicalismo e lusotropicologia. Nesse raciocínio, chega a discutir a superioridade do colonialismo português frente a de outras potências. No final da década de 1950, em uma conferência, Freyre propõe a ideia da "constelação de nações" lusotropicais, com base na unidade de sentimentos e de cultura, "na qual traços portugueses de simbiose, plasticidade, mobilidade, mestiçagem e tolerância dão origem a uma consciência transnacional ou

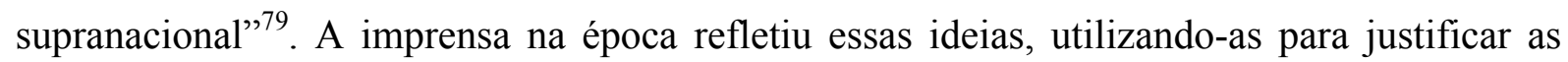
posições portuguesas na África.

Afonso Arinos compartilhava da mesma visão de Barboza, que foi seu chefe de gabinete, e aconselhava Jânio Quadros na aproximação real e anticolonialista ao continente africano. Na viagem a Lisboa, mencionada acima, Arinos tinha a intenção de denunciar o Tratado de Cooperação e Amizade firmado com Portugal, no qual o Brasil concordava com a ficção jurídica das "províncias ultramarinas” portuguesas. Segundo Barboza, estava definido entre Quadros e seu chanceler a orientação de se votar contra Portugal nas Assembleias Gerais da ONU, onde era crescente a pressão sobre Portugal.

Entretanto, a diplomacia portuguesa empreendeu forte campanha para alterar essa posição. O embaixador português no Brasil, Manuel Rocheta, com trânsito na sociedade e na política brasileira, encontrou-se com o presidente em Brasília no dia 30 de março de $1961^{80}$. Saindo desse encontro, procurou o chanceler Afonso Arinos para informá-lo, em primeira mão, sobre a mudança de posição brasileira referente ao colonialismo português. Arinos, no relato de Barboza ${ }^{81}$, perplexo, não admitiu receber tal mensagem, afinal estava alinhado com

\footnotetext{
${ }^{78}$ Como exemplo dessa posição, podemos verificá-la em no editorial do jornal carioca O Jornal, de 24 de novembro de 1974, que defende a posição brasileira pró-Portugal, sendo ao mesmo tempo anticolonialista, pois Portugal resolveria com sua "tradicional sabedoria" os problemas africanos; assim, o Brasil defende Portugal contra ambições imperialistas, ao abster ou votar contra resoluções que condenam Portugal; "Por que haveria o Brasil de hostilizar Portugal, com quem mantemos relações íntimas e indestrutíveis e a quem devemos solidariedade histórica de quase cinco séculos de união, para servir às conveniências de imperialismos que se querem exercer com o enganoso atrativo de ideologias políticas?". Fundo José Honório Rodrigues, Recortes Extraídos de Periódicos. Instituto de Estudos Brasileiros da USP.

${ }^{79}$ CANDEAS, Alessandro. Trópico, Cultura e Desenvolvimento: a reflexão da UNESCO e a tropicologia de Gilberto Freyre. Brasília: Liber Livro, 2010, P. 162-171.

${ }^{80}$ RODRIGUES, op. cit., p. 406.

${ }^{81}$ BARBOZA, op. cit., p. 343.
} 
o presidente. Ao entrar em contato com a presidência, Quadros confirmou a mudança, justificando-a com motivos emocionais. Na sequencia, o Itamaraty soltou nota confirmando, de um lado, a "firme posição anticolonialista do Governo", mas exortou "os vínculos de natureza especialíssima que unem o Brasil a Portugal" ${ }^{\prime 82}$.

Essas hesitações não ocorreram apenas com o governo de Quadros, não sendo uma característica, portanto, apenas da personalidade controversa do presidente. Já na gestão de João Goulart, em 1962, o Brasil mostrou, em menos de um ano, total ambiguidade quanto à questão de Angola. Em janeiro desse ano, o Brasil votou, com Afonso Arinos na chefia da delegação, favorável à Resolução 1.742 da ONU, que versava sobre a transferência de poder para o povo angolano ${ }^{83}$. Todavia, ao fim do ano, na XVII Assembleia Geral da ONU, já com Hermes Lima na chancelaria, o Brasil se abstém na votação das Resoluções 1.807 e 1.808 que foram aprovadas com grande margem de votos -, que versavam sobre o desenvolvimento e autonomia de Angola.

Sob a gestão de Hermes Lima à frente do Itamaraty ocorre importante episódio em relação à política externa para a África. Em 15 de março de 1963, João Goulart elaborou e publicou sua Mensagem ao Congresso Nacional, na ocasião da abertura de nova legislatura, apresentando sua diretrizes políticas, dentre elas a orientação da Política Externa. Nesta mensagem, reafirma a defesa brasileira do princípio da autodeterminação dos povos africanos, e exorta a participação das potências para acelerar o processo emancipatório, incluindo então os caso de Angola e dos territórios ultramarinos de Portugal $^{84}$. Essa referência última, no entanto, foi retirada numa retificação da Mensagem. Na súmula oficial de resumo da Mensagem, enviada à imprensa, absolutamente nada é dito sobre o colonialismo e a posição brasileira na questão ${ }^{85}$. Como bem aponta Rodrigues, a imprensa noticiou que a inclusão foi feita à revelia do ministro Hermes Lima, atribuindo-a à assessoria do presidente. $\mathrm{O}$ colunista

\footnotetext{
${ }^{82}$ RODRIGUES, op. cit., p. 406.

${ }^{83}$ SARAIVA, op. cit., p. 300.

${ }^{84} \mathrm{O}$ parágrafo controverso: "Temos reconhecido e continuaremos a reconhecer o direito à independência de todos os povos coloniais e a obrigação das Potências administrantes de acelerarem os preparativos para a autodeterminação e a independência, inclusive de Angola e demais território ultramarinos de Portugal, bem como do Sudoeste africano. O Brasil atribui, entretanto, grande importância à necessidade de que o processo de nascimento dos novos estados conte com a colaboração das Potências que antes os administravam, e se faça ordenadamente, de forma a preservar-lhes a unidade, a autoridade do governo central e a garantir bases que lhes permitam defender-se das formas insidiosas do neo-colonialismo econômico ou ideológico". RODRIGUES, op. cit, p. 426). O grifo indica o texto retirado. Procurei o inteiro teor da Mensagem Presidencial, mas apenas encontrei o fac-símile do texto acima na obra citada de José Honório Rodrigues.

${ }^{85}$ O Estado de S. Paulo, 16 de março de 1963, "Súmula da Mensagem do Presidente ao novo Congresso", p. 4.
} 
Carlos Castello Branco, d'O Jornal do Brasil, no entanto, aponta uma ampliação do texto, inicialmente aprovado pelo chanceler, pelos seus assessores diretos, Saraiva Guerreiro e Araújo Castro, que não submeteram o texto novamente a ele ${ }^{86}$. A mudança causou entusiasmo na imprensa portuguesa, que considerou no caso um recuo brasileiro.

Com esse quadro da política externa para a África no período da chamada PEI, com avanços e recuos, iniciativas e constrangimentos, teria Rodrigues razão em afirmar que "o Brasil não teve e não tem política africana. Pensou-se que ela seria formulada ao nascer o governo Jânio Quadros, mas ficou-se nas declarações iniciais. Na verdade, ela nasceu morta, quando a Missão à África foi completada com a Missão a Salazar, uma tese e uma antítese, sem síntese.” A política externa para a África, de fato, era ambígua naquele momento, e muitas vezes o discurso não era acompanhado com a prática. As iniciativas de Quadros e Arinos, mesmo que malogradas naquele momento, iriam ser retomadas em momentos posteriores. A curta trajetória de Quadros também não colaborara para o aprofundamento das ideias. Na sociedade brasileira, se, de um lado havia jovens diplomatas e intelectuais entusiastas da independência da África, valorizando os elementos africanos na formação da nacionalidade brasileira, de outro havia a tradicional valorização do mundo ocidental e, especialmente, de Portugal como verdadeiros elementos da nação brasileira. Tanto a imprensa pró-Portugal quanto o lobby direto português mostram a vitalidade da noção de continuidade, pelo Brasil, dos valores portugueses. Quadros e Arinos tiveram o mérito de enfrentar essa mentalidade e acreditado na "vocação africana" do Brasil, enxergando, para além do discurso de ligações étnicas, o interesse nacional no apoio à África livre.

A formulação da política externa estava sujeita, portanto, não só à conjuntura internacional, influenciada pela Guerra Fria e a descolonização africana, mas também à política interna e à opinião pública. Isso fica perceptível com a divisão em 3 fases da PEI, como Cruz identifica: a primeira mais ligada à personalidade de Quadros, numa perspectiva internacional mais ligada ao neutralismo; a segunda fase, ligada ao período parlamentar de João Goulart, afasta-se daquele neutralismo, e vê uma presença maior do chanceler na formulação da política externa, principalmente na figura de San Tiago Dantas. Uma diferença fundamental entre esses dois períodos é justamente a política interna, especialmente no Congresso. Segundo Cruz, com Quadros, a PEI atraía para a base governista setores da

\footnotetext{
${ }^{86}$ O Jornal do Brasil, 17 de março de 1963, “Goulart foi indiscreto na mensagem por engano”, p. 4.
} 
esquerda nacionalista - lembrando que a PEI buscava maior intercâmbio também com o bloco socialista. Entretanto, João Goulart assumia o governo já sob suspeita ideológica, e a PEI imediatamente transforma-se de um trunfo para um fardo. Em outras palavras, o debate sobre a aproximação ao mundo afro-asiático passou de um assunto apenas de política externa para uma questão também de política interna. Já na última fase, coincidente com o período presidencialista de Goulart, a PEI, sob os auspícios de Araújo Castro, abandona o tom neutralista, e define temas declaradamente prioritários. Um deles é o desenvolvimento econômico, influenciado, naquele momento, pelas ideias da Cepal e da realização da $1^{\text {a }}$ Unctad $^{87}$. Em seu famoso discurso na abertura da Assembleia Geral da ONU em 1963 (também conhecido como o discurso dos 3 D's: Desarmamento, Desenvolvimento e Descolonização), Araújo Castro coloca como tarefa da ONU a promoção do desenvolvimento econômico $^{88}$.

O foco da política brasileira para a África, muito por influência da discussão política interna, também sofre mudanças. Apesar de o discurso dos dois governos serem muito semelhantes entre si, eles diferenciaram-se na prática. Segundo Leite, enquanto a PEI sob Quadros concentrou-se em medidas práticas, como embaixadas e acordos culturais, a fim de incentivar a aproximação e o conhecimento mútuo, o governo Goulart priorizou a busca do apoio africano para o estabelecimento de um grupo unido nas questões da cooperação Sul-Sul, aumentando a barganha em negociações internacionais ${ }^{89}$. A ênfase não era tanto em relações bilaterais, apesar dos temas econômicos ainda estarem presentes. As relações comerciais, que eram muito presentes nos discursos janistas, não foram priorizadas por Goulart - ele entendia que a região africana teria baixo crescimento nas projeções. Por outro lado, o Instituto Brasileiro de Estudos Afro-asiáticos (IBEAA) já colocava mais perspectivas nas relações bilaterais com as novas nações africanas, talvez no mesmo sentido que Rangel. Reconheciam o comércio incipiente, mas afirmavam que era um projeto de futuro. Conforme aponta Henrique Altemani, o fluxo comercial Brasil-África no período entre Kubitschek e Goulart era esporádico e levemente superavitário para o Brasil. As exportações correspondiam a 1\% do total brasileiro, enquanto as importações variavam abaixo do $1 \%$ até 1963, principalmente da Argélia. Mesmo com a PEI, o intercâmbio não sofreu alterações e era concentrado na

\footnotetext{
${ }^{87}$ CRUZ, op. cit., p. 51-53.

${ }^{88}$ AMADO, Rodrigo. Araújo Castro. Brasília: Ed. UnB, 1982, p. 37.

${ }^{89}$ LEITE, op. cit., p 102.
} 
África do Sul, com quem tínhamos acordo comercial, além de países do norte africano. À época, 70\% das exportações brasileiras tinha como destino EUA e Europa. Ainda, o comércio com as colônias portuguesas era praticamente inexistente, não havendo qualquer benefício com as ditas relações especiais com Portugal $^{90}$.

\subsubsection{Governo Castelo Branco e Costa e Silva (1964-1969)}

Com o golpe, em 1964, a política externa brasileira sofre uma guinada imediata. No contexto do conflito ideológico regido pela Guerra Fria, os militares exigem a quebra das relações diplomáticas com a União Soviética, a República Popular da China e Cuba (o que de fato não ocorre), também fecham centros de pensamento nacionalista e desenvolvimentista, como o Instituto Superior de Estudos Brasileiros (ISEB) ${ }^{91}$. A política externa dos primeiros presidentes militares seria a volta do alinhamento automático com os Estados Unidos, primeiro com o chanceler Vasco Leitão da Cunha, e, depois, com Juraci Magalhães. Este, muito próximo dos militares, ele mesmo à ocasião um general de longa carreira política, assume a pasta das Relações Exteriores vindo da embaixada de Washington, onde fora colocado por Castelo Branco ${ }^{92}$, para acabar com resquícios da PEI, como diplomatas e funcionários identificados a ela ${ }^{93}$. Magalhães formula uma política externa alinhada com o pensamento típico da Guerra Fria, baseada em 3 princípios: unidade continental, solidariedade econômica continental e segurança hemisférica. A política externa adotaria o viés geopolítico defendido por Golbery do Couto e Silva, com o conceito dos "círculos concêntricos", abandonando o universalismo da PEI e assumindo para o Brasil o papel de potência média em ascensão $^{94}$.

\footnotetext{
${ }^{90}$ OLIVEIRA, Henrique Altemani. Política Externa Brasileira e Relações Comerciais Brasil-África. Tese de Doutorado. FFLCH-USP, 1987, p. 31-35.

${ }^{91}$ REIS, Daniel Aarão (coord.). Modernização, Ditadura e Democracia. Rio de Janeiro: Ed. Objetiva, 2014, p. 142.

${ }^{92}$ Quando servia como embaixador em Washington, Magalhães disse a conhecida frase "O que é bom para os Estados Unidos é bom para o Brasil", o que de certa forma refletiu a política externa dos dois primeiros presidentes da ditadura militar brasileira. Dicionário Histórico-Biográfico Brasileiro Pós-1930, http://cpdoc.fgv.br/acervo/dhbb.

${ }^{93}$ Da mesma maneira, diplomatas alinhados com o pensamento militar recebem mais espaço, como Manoel Pio Corrêa, secretário-geral do MRE em 1966 e 1967, defensor das teses geopolíticas no relacionamento com a África; Meira Penna, pró-Portugal, para quem a PEI foi um "erro doutrinal que precisava ser corrigido"; Oliveira Maia e Nestor dos Santos Lima. SARAIVA, op. cit., 2014, p. 304).

${ }^{94}$ REIS, op. cit., 143-144.
} 
Desse modo, Castelo Branco, ao assumir, recoloca o conflito Leste-Oeste na política externa, deixando de lado a ênfase Norte-Sul da PEI, forçando um realinhamento automático com os Estados Unidos. Sua política externa seria caracterizada pelo conceito de interdependência, que foi explicitado justamente no discurso de formatura da turma de 1964 dos diplomatas do Itamarati. Esse conceito encontra-se na linha de pensamento da Guerra Fria, pois está ligado à ideia de fronteiras ideológicas, na busca de aliança interamericana para combater avanços subversivos. Nessa direção, também o conceito de "círculos concêntricos" iria guiar a política externa, presente nos discursos alinhados de Magalhães e de Leitão da Cunha. Um conceito que se encaixa com o de interdependência, pois reconhece a liderança norte-americana no mundo ocidental. Nessa ideia, o interesse brasileiro coincide com as áreas de interesse da América Latina, do continente americano e da comunidade ocidental ${ }^{95}$.

Leitão da Cunha, em elucidativa entrevista concedida ao jornal O Estado de S. Paulo, em abril de 1964, evidencia essa visão de círculos como uma oposição à PEI, apesar de classificá-la como uma retificação, e não uma mudança: "Não há propriamente uma reformulação, mas uma retificação na política exterior que é na realidade uma política independente de tradição e que data de fato da monarquia. Vou além: nossa política é independente desde 1822." ${ }^{.96} \mathrm{O}$ então chanceler continua na relativização da ideia de política independente: "É preciso não esquecer que no mundo moderno o conceito de independência absoluta é uma coisa obsoleta. Relativa, porque a tendência é transformar-se em interdependência" ${ }^{\prime 97}$. Na perspectiva dos círculos concêntricos, ele coloca que, desse modo, a ênfase recai primeiro nos vizinhos do continente (Rio da Prata e América do Sul), e em segundo, nos países tradicionalmente amigos do Brasil no ocidente. Na sua opinião, a diferença dessa política com relação à do governo de Jânio Quadros é a ênfase na política bilateral, enquanto Quadros buscava a política multilateral, o que classifica como "utopia"98. Quanto à África, Leitão da Cunha afirma a posição anticolonialista brasileira, e acompanha com simpatia e solidariedade a evolução dos países africanos.

\footnotetext{
${ }^{95}$ VISENTINI, Paulo Fagundes. A Política Externa do Regime Militar Brasileiro: multilateralização, desenvolvimento e a construção de uma potência média (1964-1985). Porto Alegre: Ed. UFRGS, 1998, p. 30-34.

${ }_{96}$ O Estado de S. Paulo. "Leitão da Cunha afirma que não haverá reformulação da política exterior do Brasil". 30 de abril de 1964, p. 7.

${ }^{97}$ Ibidem.

${ }^{98}$ Ibidem.
} 
Segundo Paulo Visentini, esses conceitos eram essencialmente defensivos, buscando ganhos econômicos e políticos. Por um lado, buscava garantir o interesse do capital estrangeiro, num movimento "subimperialista"; por outro, garantia a intenção norteamericana de ter alianças em subsistema regionais. Na ideia dos formuladores da política externa brasileira, os Estados Unidos, em retorno ao apoio ideológico e militar, dariam tratamento diferenciado ao Brasil, destacando-o na região, criando condições para a expansão dos investimentos americanos no Brasil ${ }^{99}$. Magalhães, por sua vez, defende a teoria da Segurança Coletiva, que garantiria, então, os princípios da não intervenção e autodeterminação dos $\operatorname{povos}^{100}$. A ameaça a essa segurança residiria na agressão ideológica marxista-leninista, que, na concepção dos militares, pudesse contaminar os movimentos de independência no continente africano ${ }^{101}$.

Todo esse contexto no imediato pós-golpe, de luta contra o comunismo, iria influenciar a política externa, inclusive a política para a África, ocasionando um "regressismo" que afinal atinge todos os setores. No tocante à política para a África, a consequência mais notável seria o fortalecimento do apoio ao colonialismo português no continente africano. As relações com a África ocorreriam de modo diferente em três grupos distintos, com a África Negra já independente, com a África do Sul e com a África dominada pelos portugueses. Assim, em relação a esta última, o governo militar entendia que tais territórios eram de responsabilidade portuguesa, e não cabia ao Brasil passar por cima das decisões do governo de Salazar sobre eles. A ligação brasileira com esses territórios eram ligações "essencialmente portuguesas"102. A preocupação brasileira com a África, notadamente a atlântica, era com a possível influência e "contaminação" de ameaças comunistas.

Entretanto, o caminho para o continente africano não estava completamente fechado. Castelo Branco recebeu, seis meses após o golpe, o presidente de Senegal, Léopold Senghor, numa visita que, a bem da verdade, estava planejada desde antes da chegada ao poder dos militares, e seria a primeira visita de um presidente da África subsaariana ao Brasil. Ainda assim, ocorreram conversas cordiais, e foram assinados acordos comerciais e culturais.

\footnotetext{
${ }^{99}$ SARAIVA, op. cit., 1994, p. 302.

${ }^{100}$ VISENTINI, op. cit., 1998, p. 35.

${ }^{101}$ SARAIVA, op. cit., p. 303.

102 Ibidem, p. 304.
} 
Segundo Saraiva, Senghor aproveitou a oportunidade para criticar o apoio brasileiro à Portugal $^{103}$. Ainda, o Itamaraty, por meio da Divisão da África, organizou uma missão comercial para o continente, no primeiro semestre de 1965, com o objetivo de investigar as potenciais demandas comerciais africanas, elaborando listas de produtos a serem oferecidos e de produtos primários demandados pelos africanos. A missão foi chefiada pelo Ministro Mario Borges da Fonseca, e visitou Senegal, Libéria, Gana, Nigéria, Camarões e Costa do Marfim. ${ }^{104} \mathrm{Da}$ missão resultaram um relatório enviado a confederações de indústria e comércio e a intenção de estabelecimento e de sistemas de transportes entre portos brasileiros e africanos: segundo José Honório Rodrigues, nada foi feito nesse sentido, posteriormente. Em 1966, o governo brasileiro participou do Festival Mundial de Arte Negra, realizado no Senegal, além de celebrar outros acordos comerciais com Camarões e Libéria ${ }^{105}$.

De todo modo, os países africanos procuravam mais o Brasil do que o inverso, como se nota por visitas de governo africanos ao Brasil: não havia um esforço brasileiro, portanto, para manter a ponte sobre o atlântico. Além disso, surgia uma pressão de países africanos sobre o Brasil em relação ao apoio deste ao colonialismo português. Em 1967, um grupo de países, por meio de seus embaixadores, distribuiu à imprensa uma nota pedindo explicações brasileiras sobre declarações de apoio à política de Portugal na África, em reação à declaração proferida por Costa e Silva nesse sentido, quando em viagem a Lisboa ${ }^{106}$. Os representantes de Argélia, Gana, Senegal e Egito (então República Árabe Unida) acreditavam estar vendo o fortalecimento das relações entre Brasil e Portugal e consequentemente um maior apoio ao colonialismo português, principalmente em acordos como a visita de navios militares brasileiros aos portos de Angola e de incremento comercial que incluíam as colônias portuguesas na África ${ }^{107}$.

Quanto ao intercâmbio comercial, apenas em 1967 a econômica brasileira apresentaria melhoras nos indicadores. Nesse quadro, as relações comerciais com os países africanos também mostrariam leve crescimento. As exportações variam entre $1 \%$ a $2.1 \%$ do total brasileiro. As importações mostram um crescimento maior, a partir de 1967, passando de $0.8 \%$ a $2.9 \%$ em 1969. O fluxo, portanto, indica Henrique Altemani, tem crescimento maior

\footnotetext{
${ }^{103}$ SARAIVA, op. cit., 1994, p. 305.

${ }^{104}$ O Estado de S. Paulo, 09 de abril de 1965, "O Itamarati reuniu missão comercial que vai à África", p.7.

${ }^{105}$ RODRIGUES, op. cit., 1982, p. 507-510.

${ }^{106}$ Ibidem, p. 508.

${ }^{107}$ O Estado de S. Paulo, 07 de janeiro de 1967, "Diplomatas preocupados”, p. 6.
} 
do que a média total brasileira, e ao final do período Costa e Silva a balança comercial passa a ser deficitária para o Brasil. Entretanto, as relações ainda são concentradas na África austral e do norte, que concentram entre 70 e $80 \%$ das exportações no período, enquanto as importações são concentradas na Nigéria e Zâmbia. Missões comerciais marroquinas e argelinas vêm ao Brasil para negociar a compra de produtos agrícolas brasileiros (café, tabaco) e venda de fosfatos, no caso marroquino, e petróleo, no caso, argelino ${ }^{108}$. Desse modo, os governos de Castelo Branco e Costa e Silva, no que se refere à política externa para a África, não se diferenciaram: foram, de fato homogêneos, como demonstra inclusive o discurso alinhado dos chanceleres do período, principalmente Leitão da Cunha e Magalhães.

\subsubsection{Governo Médici (1969-1974)}

A partir do governo Médici (1969-1974), no entanto, começa uma nova reaproximação brasileira, principalmente na figura do já citado Mario Gibson Barboza. Para José Honório Rodrigues, o governo Médici iria fortalecer o colonialismo português, pois em sua mensagem ao Congresso, não citou a questão colonial, e seu chanceler, Barboza, também não se expressava abertamente contra o colonialismo português ${ }^{109}$. Segundo o historiador, as declarações do ministro eram vagas, na intenção de evitar qualquer confronto com os portugueses. Nesse sentido, o famoso "périplo africano" de Barboza teria a intenção de convencer os africanos a aceitar e relevar as relações especiais de Brasil e Portugal, o apoio à posição colonial de Portugal na ONU e o comércio crescente com a África do Sul aparteísta. Assim, apenas durante a viagem, Barboza teria percebido os sentimentos africanos para com a independência dos territórios portugueses na África, conforme os governantes lhe pediam para mudar de posição na questão colonial.

No entanto, essa avaliação dura de Rodrigues sobre a gestão de Barboza merece uma revisão: em suas memórias, o então chanceler coloca que a partir da sua experiência com Afonso Arinos, de quem foi chefe de gabinete na primeira gestão frente ao Itamaraty, formularia a política externa na sua gestão na pasta de Relações Exteriores ${ }^{110}$. Ainda, antes mesmo dessa experiência, Barboza era Ministro-chefe da missão brasileira na ONU, onde

\footnotetext{
${ }^{108}$ OLIVEIRA, op. cit., 1987, p. 76-78.

${ }^{109}$ RODRIGUES, op. cit., 1982, p. 511-518.

${ }^{110}$ BARBOZA, op. cit., 2007, p. 342.
} 
teve contato com discussões e com diplomatas sobre a questão colonial. Em seguida, após a saída de Quadros e Arinos do governo, continuou a atuar com San Tiago Dantas como chefe de gabinete, com quem teve mais uma grande experiência quanto à formulação da política externa. Desse modo, não é equivocado dizer que ele tinha grande experiência tanto na questão africana quanto na questão da relação do Brasil com Portugal, questões, enfim, interligadas. Ele enxergou bem o dilema no qual o Brasil se encontrava, pois tinha laços históricos tanto com Portugal quanto com o continente africano: por um lado, herdou a língua, a unidade territorial, a matriz cultural dos portugueses; por outro, era uma ex-colônia, portanto solidária aos anseios de autodeterminação dos africanos, cuja formação demográfica em muito deve aos tráfico de escravos, além da influência cultural profunda daí advinda. A seu ver - e isso não deve ser confundido como uma opinião geral do Itamaraty, pois, como notado acima, havia diplomatas que discordavam da aproximação com a África - qualquer tomada de posição poderia gerar a hostilidade aberta pela outra parte. Decide então, tentar empreender um esforço de mediação, a fim de conduzir uma saída pacífica a uma questão em vias de explodir. E essa foi a política acertada com o presidente Médici, que deu autonomia suficiente para Barboza durante seu exercício ${ }^{111}$.

Ciente das diferentes posições tanto no governo quanto na sociedade, Barboza afirma em suas memórias que não esclareceu sua linha adotada para a questão pois poderia colocar em risco todas as iniciativas e planos ali colocados, afirmação essa que ajuda a explicar a forte crítica de Rodrigues à sua atuação. Cabe dizer também que essa questão é cara ao antigo chanceler, visto que dedicou mais de 100 páginas ao assunto, mais do que outros diplomatas em seus próprios relatos. Para ele, sua linha de política externa representava o cumprimento de uma obrigação histórica, pois somente o Brasil tinha a possibilidade de mediar a uma emancipação segura dos territórios portugueses na África. Ele relata, então, alguns dos obstáculos que enfrentou no governo, que, de fato, não foram explorados por outros autores. Um deles foi no início de sua gestão, quando ficou a par de manobras navais conjuntas de Brasil e Portugal, na costa africana. O chanceler, ciente do peso político que esse episódio poderia causar nas relações com os países africanos - e também provavelmente com a memória da reação de países africanos à ida de navios brasileiros a portos angolanos, como

\footnotetext{
${ }^{111}$ Ibidem, p. 366-368.
} 
citado acima - busca, por intermédio do presidente, cancelar as manobras. Após resistência da Marinha, Médici ouviu Barboza e atendeu às suas ponderações ${ }^{112}$.

Outros dois episódios dentro do governo merecem destaque, relatados por Barboza: um com Ernesto Geisel, então presidente da Petrobrás, e outro com Delfim Netto, ministro da Fazenda. Ambos queriam que o Brasil se associasse a Portugal em busca de interesses comerciais. Geisel desejava explorar o petróleo de Angola, em conjunto com Portugal, e insistia firmemente na posição. Em uma reunião ministerial sobre os contratos de risco de petróleo, Barboza foi convidado a participar, entre outros ministros, e inicialmente Geisel colocou sua posição sobre a presença brasileira na exploração de petróleo em Angola. O chanceler retorquiu, colocou sua posição, principalmente sua avaliação de que a África portuguesa iria atingir a independência. Médici ficou ao lado chanceler.

Com Delfim, o embate seguia quase na mesma linha, com a diferença de ter aparecido na imprensa ${ }^{113}$. Meses antes da viagem de Barboza à África, sendo essa já conhecida e divulgada, o assessor internacional do Ministério da Fazenda, Vilar de Queirós, havia declarado que "a África era um mercado promissor, e que as operações brasileiras no continente africano teriam por base os territórios portugueses, de onde partiriam as investidas comerciais do Brasil para os outros países" "114. A viagem de Barboza não incluía as possessões portuguesas. Sentindo comprometida sua intenção de abertura para a África, pois nem o ministro da Fazenda nem o presidente contestaram a declaração de Queirós, Barboza, por meio do secretário-geral do Itamaraty, Jorge de Carvalho e Silva, lançou nota à imprensa criticando o assessor por divulgar opinião pessoal, pois é competência exclusiva do presidente a formulação da política externa brasileira, cabendo a execução ao ministério das Relações Exteriores. Instalada a crise na imprensa, Médici chamou pessoalmente Barboza para esclarecer a questão, e, conforme o relato deste, bateu o pé para evitar futuras intromissões em seu ministério, inclusive colocando seu cargo à disposição caso Delfim Netto continuasse a intrometer-se nos assuntos do Itamaraty.

Segundo Saraiva, a viagem empreendida por Barboza à África em outubro e novembro de 1972, que ficou conhecida como périplo africano, seria uma evidência do

\footnotetext{
${ }^{112}$ BARBOZA, op. cit., 2007, 369-372.

${ }^{113}$ O Estado de S. Paulo, 11 de fevereiro de 1972, "Há uma crise Gibson-Delfim”, p. 1; O Jornal do Brasil, 11 de fevereiro de 1972, "Itamarati não leva em conta opinião de Vilar", p. 3.

${ }^{114}$ O Estado de S. Paulo, idem.
} 
esforço oficial para alcançar a África ${ }^{115}$. Foi, sem dúvida, um dos pilares da gestão de Barboza, cuidadosamente planejada por ele, e, como visto, defendida dentro do próprio governo. Decidiu inicialmente por visitar 8 países, nessa ordem: Costa do Marfim, Gana, Togo, Daomé (atual Benim), Zaire (atual República Democrática do Congo), Camarões, Nigéria e Senegal. Gabão seria incluso ainda, antes da ida a Senegal. Os destinos não foram escolhidos ao acaso, bem ao contrário, levando em conta fatores culturais ${ }^{116}$. A missão seria composta não apenas por diplomatas, mas também por empresários, não visando apenas interesses comerciais e econômicos, mas também projetos de programas de cooperação no setor cultural e assistência técnica ${ }^{117}$. A missão assinava com cada país uma declaração conjunta, contendo a reafirmação de princípios gerais do direito internacional, autodeterminação dos povos, não intervenção, fortalecimento da ONU, do comércio internacional, estabelecimento de linhas de transporte, inter alia, e também a assinatura de acordos comerciais e culturais ${ }^{118}$.

Barboza não visitou apenas capitais, mas também cidades no interior e portos, centros industriais e universidades. Em seu relato sobre a viagem, o chanceler descreve situações peculiares pelas quais passou, como jantares apimentados e danças com reis ${ }^{119}$, algumas vezes recebido com desconfiança, como em Gana, onde ouviu do chanceler ganês que o Brasil recebia prisioneiros da guerra colonial portuguesa e os mantinha em campos de concentração, além do fornecimento de todo armamento utilizado por Portugal ${ }^{120}$, informações desmentidas pelo chanceler brasileiro. Principalmente em Togo e Daomé, mas também na Nigéria, teve contato com as comunidades de agudás, descendentes de ex-escravos brasileiros que retornaram ao continente africano, levando de volta hábitos e conhecimentos adquiridos no Brasil. Como apontava Rodrigues, Barboza encontrou posições contrárias e críticas a

\footnotetext{
${ }^{115}$ SARAIVA, op. cit., 1994, p. 306.

${ }^{116}$ Ibidem, p. 396.

${ }^{117}$ Jornal do Brasil, 30 de julho de 1972, "Gibson oferece ajuda à África”, p. 4. Fundo José Honório Rodrigues, IEB/USP.

118 Visentini apresenta lista exaustiva dos acordos diplomáticos firmados pelo governo brasileiro com os países africanos visitados por Barboza. VISENTINI, op. cit., 1998, p. 181. Também SARAIVA, op. cit., 1994, p. 412.

${ }^{119} \mathrm{Na}$ visita a Daomé, hoje Benim, cercado de hospitalidade principalmente pelos descendentes de brasileiros ex-escravos e retornados, Barboza foi levado à presença do rei de Abomei, figura histórica no país, e também foi muito bem tratado, chegando a dançar com o rei, contagiando também seus assessores (BARBOZA, op. cit., 2007, p. 421). Alberto da Costa e Silva, oficial de gabinete do chanceler, também descreveu a cena. SILVA, Alberto da Costa e. O Vício da África e outros vícios. Lisboa: João Sá da Costa, 1989, p. 19-23 e 2011, p. 115118 .

${ }^{120}$ BARBOZA, op. cit., 2007, p. 410.
} 
Portugal, mas, segundo ele, sem receber pressões para que o Brasil mudasse de posição em relação à questão colonial portuguesa ${ }^{121}$.

A perspectiva de Barboza sobre a política em cuja formulação ele próprio participou ajuda a entender melhor a crítica feita por José Honório Rodrigues, mencionada anteriormente, mas também deve ser tomada cum grano salis. Apesar de seu sincero esforço, e, nas palavras dele, não ter concebido a aproximação à África como apenas "abertura de vias de intercâmbio comercial e cooperação mútua, assinatura de acordos, a proclamação de princípios gerais de convivência internacional, mas também o reconhecimento e a retomada de uma das raízes da nossa formação", o Brasil não rompeu com os constrangimentos infligidos principalmente pela relação com Portugal, pela omissão nas Assembleias Gerais da ONU, e pela insistência do comércio com a África do Sul, apesar das óbvias infrações aos direitos humanos que ali ocorriam. A política externa e principalmente o "périplo" de Barboza podem ter trazidos resultados práticos, comerciais e econômicos, podem ter despertado a consciência mútua dos problemas de cada lado do Atlântico, mas tal política não prosperaria, como o próprio o reconheceria ${ }^{122}$. Seriam necessários outros acontecimentos que forçassem a posição "em cima do muro" em relação ao colonialismo português e o racismo sul-africano, e a percepção da mudança do cenário internacional.

A posição brasileira, mais uma vez, era ambígua: declarava-se contra o apartheid, mas ficava ao lado da África do Sul nas questões concernentes a Portugal. Evitava falar de "províncias ultramarinas", por considerá-las uma ficção, mas apoiava Portugal pelo princípio da não-intervenção em assuntos internos. O cenário mudava rapidamente, todavia, principalmente após o choque do petróleo, em 1973, quando uma unidade afro-árabe se intensifica, unidade esta que passa a agir ameaçando de boicote de petróleo à África do Sul, Portugal e os países que os apoiassem. Porém, ainda em 1973, o Brasil votaria contra a resolução da ONU, que aprovou a independência unilateral de Guiné-Bissau e condenaria Portugal pela guerra colonial. O argumento brasileiro para tal voto era a falta de elementos jurídicos para o reconhecimento da soberania de um país ${ }^{123}$.

\footnotetext{
${ }^{121}$ BARBOZA, op. cit., 2007, p. 432.

122 Ibid., p. 443.

${ }^{123}$ RODRIGUES, op. cit., 1982, p. 518-519.
} 


\subsubsection{Governo Geisel (1974-1979)}

O cenário provocado pelo choque do petróleo iria coincidir com a mudança de governo, e o novo chanceler, Antonio Francisco Azeredo da Silveira, testemunharia uma grande mudança nas relações com Portugal. Pouco depois da troca do governo brasileiro, ocorre a Revolução dos Cravos em Portugal, a 25 de abril de 1974, derrubando o governo herdado de Salazar e provocando a saída dos portugueses de suas colônias africanas. Com essas mudanças e as necessidades energéticas em risco, o chamado Pragmatismo Responsável do período Geisel-Azeredo seria capaz de finalmente mudar as posições brasileiras na ONU e em relação à África portuguesa. O Brasil passaria ainda por dois momentos de pressão no sentido de mudar sua política externa. O primeiro, conforme Rodrigues, ocorre quando o Brasil é incluído numa lista de 6 países a receberem sanções econômicas, pelo apoio a Portugal e à África do Sul, lista essa feita por 17 países da África Central e Oriental, colocando o Brasil na iminência de sofrer bloqueio do petróleo árabe ${ }^{124}$. Não era a primeira vez que o Brasil recebia pedidos para mudar de posição em relação a Portugal, aproveitando de sua influência ${ }^{125}$; porém essa nova pressão continha, de fato, um tom mais agressivo.

O segundo momento de pressão ocorreu no Conselho Econômico e Social da ONU, quando a Argentina encaminhou projeto sobre recursos naturais, mais especificamente sobre padrões internacionais para a consulta e exploração cooperativa de recursos que participem dois ou mais Estados, assunto que afetava diretamente a disputa pelos recursos hidrelétricos no Rio Paraná, para a construção da usina de Itaipu. Nessa reunião, os países africanos apoiaram fortemente a posição argentina, contrária aos interesses energéticos brasileiros. A imprensa brasileira percebeu o movimento, interpretando-o como reação africana à posição brasileira em relação ao não reconhecimento de Guiné-Bissau, o que levou, em seguida, a mudança na posição brasileira quanto ao reconhecimento desta ${ }^{126}$.

Desse modo, nesse contexto, o governo Geisel, assim como o fez 14 anos antes Jânio Quadros, traria uma reviravolta na política externa brasileira, nas palavras de Rodrigues ${ }^{127}$.

\footnotetext{
${ }^{124}$ RODRIGUES, op. cit., 1982, p. 521.

${ }^{125}$ Em 1972, por exemplo, o chanceler queniano pede para o Brasil usar de sua influência sobre Portugal para forçar a mudança de governo em Angola, Guiné e Moçambique. Jornal do Brasil, 30 de julho de 1972, p. 4. Fundo José Honório Rodrigues, IEB/USP

${ }^{126}$ O Estado de S. Paulo, 16 de maio de 1974, "Brasil muda posição na África", p. 18.

${ }^{127}$ RODRIGUES, op. cit., 1982, p. 522
} 
Também Fonseca afirma uma mudança de curso na ascensão de Geisel à presidência. Com o chamado Pragmatismo Responsável, "desenhava-se um afastamento em relação à proposta doutrinária vigente e fazia-se uma crítica implícita do "ideologismo" que teria orientado os momentos imediatamente anteriores à formulação diplomática" ${ }^{2128}$. O primeiro gesto seria o reconhecimento de Guiné-Bissau e o apoio à sua entrada nas Nações Unidas, antes mesmo do fim das negociações com Portugal ${ }^{129}$. A mudança na postura é evidente já no discurso, apesar de Geisel, em seu pronunciamento de posse, não haver citado a questão africana ${ }^{130}$. Azeredo, por sua vez, na abertura da $24^{\mathrm{a}}$ Assembleia Geral da ONU, em setembro de 1974, já no desenrolar dos efeitos da Revolução dos Cravos, saúda os representantes da República de Guiné-Bissau, para em seguida afirmar que não mais deve haver atrasos na descolonização:

Logo salta aos olhos o problema da descolonização. Temos sobre esta questão uma posição de absoluta clareza: o Brasil acredita, sem restrições, que não se justificam protelações ou subterfúgios na condução do processo descolonizatório, no próprio Continente americano e em todo o mundo. O Brasil prestará o seu apoio a que os povos ainda sujeitos a formas de dominação colonial possam alcançar, no mais curto prazo possível, a independência nacional a que aspiram. ${ }^{131}$

No mesmo momento, Azeredo continua explicitando a mudança, afirmando o desejo brasileiro de ver concluída a independência tanto de Angola quanto de Moçambique, e, ainda, condena e repudia o apartheid. Aparentemente, pelo menos no discurso, o Pragmatismo Responsável colocaria um novo curso para a política externa. Oficialmente, não havia rompimentos com a política externa regida pelos militares desde 1964, e em nenhum momento há uma referência explícita à PEI, muito porque os militares a identificavam com o populismo de inclinações esquerdistas ${ }^{132}$. De todo modo, a Revolução dos Cravos e a mudança de regime em Portugal retira um constrangimento que impediu por anos uma posição mais assertiva brasileira em relação aos territórios de língua portuguesa na África.

Assim, já em novembro de 1974 Azeredo, com a intenção de antecipar o relacionamento político com as colônias portuguesas, conversa com Ítalo Zappa (então chefe

\footnotetext{
${ }^{128}$ FONSECA JR., Gelson. Legitimidade e outras questões internacionais. São Paulo: Paz e Terra, 1998, p. 294.

${ }^{129}$ VISENTINI, op. cit., 1998, p. 242 e SARAIVA, op. cit., 1994, p. 313.

${ }^{130}$ RODIRGUES, op. cit., 1982, p. 525.

${ }^{131}$ CORRÊA, Luiz Felipe de Seixas. O Brasil nas Nações Unidas: 1946-2011. Brasília: FUNAG, 2012, p. 396.

${ }^{132}$ FONSECA JR., op. cit., 1998, p. 300.
} 
da Divisão de África) e Ovídio de Andrade Melo para iniciarem o contato com os movimentos de independência em Angola e Moçambique. A ideia era o Brasil ser totalmente isento do processo de libertação, sem escolher lados. De Zappa surge a ideia da criação de Representações Especiais, com status de embaixadas, em Angola e Moçambique, com o aval do governo português, já depois da Revolução. Ovídio aceita o desafio, e já em janeiro parte para a África para encontrar os líderes dos movimentos de libertação: Marcelino dos Santos, da FRELIMO, de Moçambique; Agostinho Neto, do MPLA, de Angola; Holden Roberto, do FNLA; e Jonas Savimbi, do UNITA ${ }^{133}$, também de Angola, todos em exílio. Os encontros serviram para receber o consentimento do estabelecimento das Representações Especiais brasileiras em Angola e Moçambique, sendo que Marcelino dos Santos não consentiu com o plano, alegando que os moçambicanos, depois de tantos anos testemunhando o apoio brasileiro ao colonialismo português, não estavam mais acostumados a verem o Brasil como amigo $^{134}$. Em 27 de fevereiro de 1975, o Brasil estabeleceu relações diplomáticas com o governo de transição em Luanda, sendo o único país a estar presente durante todo o processo de independência ${ }^{135}$.

Depois de estabelecida a embaixada, Ovídio permaneceu em Angola, testemunhando a luta entre os três movimentos pelo poder em Angola. Apesar do acordo com o governo português de um governo tripartite em Angola (conhecido como Acordo de Alvor), com a passagem para a independência - ou seja, a saída dos portugueses - marcada para o dia 11 de novembro, os três movimentos entraram em conflito, do qual o MPLA de Agostinho Neto sairia vitorioso. No entanto, o conflito continuaria, inclusive no dia da liberação. Ovídio foi extremamente corajoso ao permanecer em Luanda, em meio ao conflito, ora estabelecido no prédio que servia antes ao consulado brasileiro, ora no famoso Hotel Trópico, por onde muitas legações de países passaram. Além da dificuldade óbvia por estar em território em conflito, a comunicação com o Itamaraty era dificultada pela hesitação de Azeredo, segundo relato de Ovídio de Melo ${ }^{136}$. Cerca de dois meses antes da liberação, Azeredo pensava em

\footnotetext{
${ }^{133}$ Tanto a FNLA e a UNITA recebiam apoio externo, aquela dos EUA e do Zaire de Mobutu, e esta da África do Sul; o MPLA teve apoio de tropas cubanas

${ }^{134}$ MELO, Ovídio de Andrade. Recordações de um removedor de mofo no Itamaraty. Brasília: FUNAG, 2009, p. 111 e RODRIGUES, op. cit., 1982, p. 523.

${ }^{135}$ SPEKTOR, Matias. Azeredo da Silveira: um depoimento. São Paulo: Ed. FGV, 2010, p. 95.

${ }^{136}$ MELO, op. cit., 2009, p. 126.
} 
fechar a Representação de Luanda, o que gerou protestos de Ovídio, que inclusive foi chamado ao Brasil para consulta, mas não foi recebido pelo chanceler.

Nesse meio tempo, Portugal reforçou as cláusulas do Acordo de Alvor, dando novo ímpeto ao esforço brasileiro. De volta a Luanda, ainda em meio ao conflito, o representante brasileiro esperava as orientações do Itamaraty para o reconhecimento imediato do governo do MPLA. Outros representantes estrangeiros também não sabiam se suas nações iriam reconhecer de pronto o novo governo. A orientação esperada veio apenas dois dias antes do 11 de novembro, num comunicado afirmando que o governo brasileiro reconhecera o governo de Luanda no dia 10, por meio de declaração à imprensa, sendo o Brasil o primeiro país a fazê-lo ${ }^{137}$. Azeredo, em depoimento ao CPDOC sobre sua gestão no Itamaraty, afirma que não havia dúvida em quem apoiar na independência de Angola. O chanceler compara a FNLA e a UNITA como "um partido boliviano no Paraguai ou vice-versa", o que facilitaria o apoio ao MPLA $^{138}$. Azeredo afirma que antes de reconhecer o governo de Angola, consultou as potências: conversou com a Alemanha, a França e Inglaterra, que não se opuseram, e também com Kissinger, secretário de Estado americano, que também não se opôs. O processo de reconhecimento, pelo menos nas palavras de Ovídio de Melo, não se deu de maneira tão simples, visto que permaneceu em Luanda em meio a um conflito armado.

$\mathrm{Na}$ sequência, as relações com Moçambique também tiveram avanço. Apesar do contato a partir de janeiro de 1975, a Frelimo não convidou a representação brasileira para a declaração de independência, em junho de 1975. Após a declaração amistosa de Azeredo na Assembleia Geral da ONU, as relações começaram a melhorar. Com o pronto reconhecimento do governo do MPLA, o diálogo melhorou ainda mais, e o Brasil estabeleceu relações diplomáticas com Moçambique ao dia 14 de novembro de $1975^{139}$.

A aproximação diplomática não se deu somente com a antiga África portuguesa. A África austral e oriental também receberam atenção. O Brasil visitou e recebeu visitas de ministros e autoridades africanas. Em 1975, chanceleres de Quênia e Zâmbia visitam o Brasil. Acordos são assinados com Marrocos, Gabão, Mauritânia, Argélia, Libéria, Guiné-Bissau, Gana, Líbia, Senegal e Cabo Verde. O Brasil estabelece relações diplomáticas com Alto Volta (hoje Burkina Faso), Níger e Libéria. Segundo Vizentini, diversificam-se a origem e destino

\footnotetext{
${ }^{137}$ MELO, op. cit., 2009, p. 130.

${ }^{138}$ SPEKTOR, op. cit., 2010, p. 95.

${ }^{139}$ Ibidem, p. 95.
} 
das exportações e importações a partir do governo Geisel ${ }^{140}$. O fluxo comercial vem num crescente desde 1969, atingindo um ápice em 1974; as exportações e importações para a África naquele ano representavam 1,05\% e 2,76\% do total brasileiro, e em 1974, 5,24\% e $5,26 \%$, respectivamente ${ }^{141}$. A África do Sul era o maior destino das exportações brasileiras em 1969, com um recorde de 67\% na participação das exportações para a África (mas não contabilizava nem 1\% das exportações totais do Brasil). Mas a partir daí tem contínua queda, chegando a 9\% em 1974 ${ }^{142}$. Em 1976, segundo Rodrigues, o comércio com Angola já se equiparava com o volume do comércio com a África do Sul, sendo o maior parceiro já a Nigéria. Essa queda se dá pela pressão crescente de outros países africanos contra as relações brasileiras com o governo de regime aparteísta da África do Sul, coerente com o reiterado discurso de Azeredo, principalmente nas Assembleias Gerais da ONU condenando a discriminação racial. Até o fim do governo Geisel, o Brasil se posicionaria contra a África do Sul em suas medidas racistas, como a criação de reservas tribais na região do Transkai, mudando uma posição que até 1973 era de tácito apoio ao colonialismo português e vagas condenações ao apartheid. O aumento das exportações fica num primeiro momento localizada nos países visitados por Gibson Barboza, mas depois é reforçada com os reconhecimentos das ex-colônias portuguesas no período Geisel. Durante o governo Médici, as importações continuam crescendo mais que as exportações, continuando os déficits brasileiros na balança comercial, invertendo-se a situação no governo seguinte - tal mudança se dá pela importação de petróleo, crescente num governo e decrescente no outro. As relações comerciais, nos dois governos, ainda se manteriam concentradas na África do norte e na república sul-africana, além de Nigéria e Zâmbia. E, como dito, a África do Sul perde espaço no comércio brasileiro devido à pressão internacional ${ }^{143}$.

\subsubsection{Governo Figueiredo (1979-1985)}

O governo Figueiredo, iniciado em 1979, daria continuidade à política africana dos anos anteriores, com especial prioridade à África de língua portuguesa, como fica perceptivel

\footnotetext{
${ }^{140}$ VISENTINI, op. cit., 1998, p. 244.

${ }^{141}$ BANCO do Brasil. Intercâmbio comercial, 1953-1976. V. 1. Rio de Janeiro: Banco do Brasil, 1977, p. 203.

${ }^{142}$ Ibidem, p. 206.

${ }^{143}$ OLIVEIRA, op. cit., 1987, p. 140-147.
} 
na mensagem presidencial ao Congresso Nacional: "Especialmente com as nações de língua comum - Angola, Cabo Verde, Guiné-Bissau, Moçambique e São Tomé e Príncipe - estamos passando a uma fase mais produtiva, como evidencia a aceleração de contatos, visitas, entendimentos" ${ }^{\text {144 }}$. Ramiro Saraiva Guerreiro, o novo chanceler, coloca a orientação do governo como "uma política de compreensão e entendimento com a África", que se tornou possível somente após o fim do domínio português, cuja influência era uma "hipoteca" que impedia o aprofundamento das relações e da confiança ${ }^{145}$. Guerreiro afirma que a política externa de Figueiredo era uma continuação, um aprofundamento da postura de Geisel, mais política do que econômica. Um exemplo dá-se com a primeira visita de um chefe de governo brasileiro ao continente africano: Figueiredo visitou, em 1983, Nigéria, Senegal, GuinéBissau, Cabo Verde e Argélia ${ }^{146}$. Ainda havia pressões internas quanto às relações com a África do Sul, seja vindo da direita ou da esquerda.

Entretanto, o governo Figueiredo, e também os países africanos, já enfrentavam dificuldades geradas pelas crises das dívidas externas, provocando recuos em projetos previstos anteriormente ${ }^{147}$. Os efeitos do segundo choque do petróleo colocavam problemas e limitações à cooperação Sul-Sul, que começava a se desenvolver ${ }^{148}$. As exportações para a África tiveram um crescimento entre os anos 1982 e 1984, atingindo o ápice neste ano de USD1,7 bilhões (9,3\% das exportações brasileiras), mas logo entraram em declínio, assim como o fluxo total.

Henrique Altemani aponta que o início do período Figueiredo mostrava grande ampliação do comércio com o terceiro mundo: em 1982, respondia por 40\% das exportações e cerca de $60 \%$ de importações. O quadro, como dito, seria quebrado pela crise das dívidas externas. As exportações, durante o governo Figueiredo tiveram um crescimento significativo que se manteve no início do governo Sarney, do mesmo modo que as importações. Ainda segundo Oliveira, a recuperação das importações da África a partir de 1983 ocorre pela diversificação de fornecedores de petróleo, tendo a África significativa participação.

\footnotetext{
${ }^{144}$ MOURÃO, Fernando A. A. e OLIVEIRA, Henrique Altemani. O processo de definição da Política Externa Africana no Brasil. In: OLIVEIRA, Henrique Altemani e ALBUQUERQUE, José Augusto Guilhon. A Política Externa Brasileira na Visão de seus Protagonistas. Rio de Janeiro: Ed. Lumen Juris, 2005, p. 71.

${ }^{145}$ VISENTINI, op. cit., 1998, p. 329.

${ }^{146}$ MOURÃO e OLIVEIRA, op. cit., 2005, p. 71-72.

${ }^{147}$ BECARD, Danielly Silva Ramos. Relações Exteriores do Brasil Contemporâneo. Petrópolis: Vozes, 2009, p. 22.

${ }^{148}$ MOURÃO e OLIVEIRA, op. cit., 2005, p. 73.
} 
Entretanto, o decrescente fluxo comercial na década de 1980, conforme Altemani, não ocorre apenas pela crise das dívidas, mas também pela diminuição nas importações totais de petróleo. A concentração de parceiros comerciais também ocorre no governo Figueiredo. As exportações brasileiras concentram-se na Nigéria, Argélia, Egito, Angola e Zaire, enquanto as importações ficam por conta de apenas 3 países: Argélia, Angola e Nigéria ${ }^{149}$.

\subsubsection{Governo Sarney (1985-1990)}

A política externa brasileira manteve o interesse na África a partir da redemocratização, mas a crise da dívida externa impôs limites. Sarney, no tradicional discurso de abertura da Assembleia Geral da ONU, voltava a condenar o apartheid e apoiava a independência da Namíbia (que ainda estava sob administração sul-africana), declarando a quebra de relações comerciais com a África do Sul ${ }^{150}$. Seu chanceler no início do mandato, Olavo Setúbal, reafirmou esse discurso em pronunciamento na Câmara dos Deputados, e sistematicamente condenava as ações da África do Sul ${ }^{151}$.

Em 1986, Setúbal deu lugar a Roberto de Abreu Sodré. Ele continuou a pressão em relação ao regime do apartheid da África do Sul, enquanto a guerra civil em Angola aumentava de intensidade, ainda numa linha da Guerra Fria, com tropas apoiadas pela União Soviética e Cuba e, do outro lado, pelos EUA. O Brasil estava consciente também da situação econômica da África, participando de Assembleia especial da ONU para tratar do assunto ${ }^{152}$.

Sarney seguiu o exemplo de Figueiredo e visitou Cabo Verde e Angola, durante seu governo, onde foi bem recebido. O presidente recebeu visitas de autoridades da Argélia, do Zaire, Cabo Verde, Moçambique, bem como de representantes do Povo do Sudoeste Africano, que viria a ser a Namíbia. Na questão da militarização do Atlântico Sul, o Brasil propôs a iniciativa da criação da Zona de Paz e Cooperação no Atlântico Sul (ZOPACAS), depois formalizada por resolução da ONU, em 1986, a fim de promover cooperação regional e manutenção da paz e segurança na região ${ }^{153}$. Ainda, outra iniciativa de relevância no

\footnotetext{
${ }^{149}$ OLIVEIRA, op. cit., 1987, p. 239 e 243.

${ }^{150}$ MOURÃO e OLIVEIRA, op. cit., 2005, p. 74.

${ }^{151}$ BARRETO, Fernando de Mello. A política externa após a redemocratização. Brasília: FUNAG, 2012, p. 35.

152 Ibidem, p. 83-84.

${ }^{153}$ MOURÃO e OLIVEIRA, op. cit., 2005, p. 75.
} 
governo Sarney foi o $1^{\circ}$ Encontro dos Chefes de Estado e de Governo dos Países de Língua Portuguesa, em reunião realizada em São Luís do Maranhão em 1989, com a participação de Angola, Cabo Verde, Guiné-Bissau, Moçambique, Portugal e São Tomé e Príncipe. Foi criado o Instituto Internacional da Língua Portuguesa, no que viria a ser o embrião da Comunidade dos Países de Língua Portuguesa ${ }^{154}$.

As relações com a África, principalmente as político-comerciais, sofreriam com o contexto financeiro desfavorável que aflige a década de 1980. Com isso, apesar de procurar manter as linhas gerais da política externa de Figueiredo, o governo Sarney não confere prioridade ao continente africano na diplomacia brasileira. Nesse sentido, conforme afirma Cláudio Oliveira Ribeiro, as relações externas Brasil-África sofrem ajustes de acordo com a limitação imposta pelo cenário internacional ${ }^{155}$. Nas relações comerciais, as linhas de crédito e o comércio de countertrade são prejudicados pela crescente deterioração da situação financeira dos países africanos. São dessa época as origens das dívidas externas africanas em relação ao Brasil, que no final dos anos 1990 e durante o governo Lula seriam renegociadas e eventualmente receberiam perdão por parte do governo brasileiro, como será analisado no segundo capítulo. Segundo Analúcia XXX, além da crise financeira, outros obstáculos impediam maior aproximação, como o baixo nível de industrialização africano e a ainda presente influência das ex-metrópoles nos países africanos, que direcionava esforços e estruturas para a Europa ${ }^{156}$.

Ao mesmo tempo, cresceu a importância da integração regional sul-americana dentro da agenda diplomática brasileira. Consequentemente, a presença brasileira no continente africano diminui, sendo inclusive substituída por países europeus, como o caso de Portugal em Angola. O distanciamento ocorreu progressivamente, com a percepção das empresas brasileiras, com exceção das empresas de grande porte, da falta de oportunidades comerciais em países africanos, algo que permaneceria, em grande medida, até os anos $2000^{157}$. Com isso, ao longo do governo Sarney, ocorre a tendência de concentração de esforços diplomáticos nos países de língua portuguesa, como visto acima, e eventualmente com a

\footnotetext{
${ }^{154}$ CPLP. Histórico. Acessado em www.cplp.org. Consultado em 07 de janeiro de 2015.

${ }^{155}$ RIBEIRO, Cláudio Oliveira. Crise e Castigo: as relações Brasil-África no governo Sarney. In: Revista Brasileira de Política Internacional, n. 51, p. 41, 2008.

${ }^{156}$ PEREIRA, Analúcia Danilevicz. A Política Externa do Governo Sarney: A Nova República diante do reordenamento internacional (1985-1990). Porto Alegre: UFRGS, 2003, p. 71.

${ }^{157}$ Ibidem, p. 49 e 55.
} 
Nigéria e África do Sul, na medida que esta começa a mostrar iniciativas contra o regime do apartheid.

\subsubsection{Governos Collor e Itamar (1991-1994)}

No período Collor, a política externa africana teve gradativa diminuição de importância. As duas características do período, segundo Becard, foram o rápido declínio do intercâmbio comercial, salvo contatos pontuais e prioridades, e a desconstrução do discurso culturalista. Nesse sentido, houve uma diminuição de diplomatas brasileiros no continente africano, além da diminuição do fluxo comercial. Do lado africano, também existiam grandes dificuldades, econômicas e sociais ${ }^{158}$. Francisco Rezek foi o chanceler por maior parte da curta passagem de Collor no governo, e acompanhou as reformas políticas tendentes a acabar com o regime aparteísta da África do Sul, manifestando-se positivamente com relação à independência da Namíbia e às medidas legislativas para o fim do apartheid. Mandela, já livre da prisão e eleito Presidente do Congresso Nacional, visita em 1991 o Brasil, ocasião na qual Collor anunciava o apoio irrestrito do "povo brasileiro a todos seus compatriotas empenhados em fundar a democracia na África do Sul". Collor teve tempo ainda de visitar 4 países africanos: Namíbia, Angola, Moçambique e Zimbábue ${ }^{159}$. Já com Celso Lafer na pasta do Itamaraty, ocorreu reunião da Comissão Mista Brasil-Angola, na qual a Petrobrás firma protocolos de intenção para ampliar sua presença e atuação em Angola ${ }^{160}$.

Já o governo Itamar tentou reativar as relações comerciais. Incentivou a reaproximação com a África do Sul, que caminhava para o fim do regime do apartheid. Com isso, o fluxo comercial entre os dois países aumentou consideravelmente. O Brasil participou de missões de paz da ONU no continente africano, em Moçambique, Uganda e Angola. Em 1994, deu continuidade ao encontro dos países de língua portuguesa, em reunião em Brasília e propondo a criação da comunidade, com sede em Lisboa ${ }^{161}$. Fernando Henrique Cardoso ficou à frente do MRE por curto período, no qual planejava visitar a África, dando prioridade à região austral e lusófona: Cabo Verde, Senegal, São Tomé e Príncipe, Guiné-Bissau,

\footnotetext{
${ }^{158}$ BECARD, op. cit., 2009, p. 57.

${ }^{159}$ BARRETO, op. cit., 2012, p. 156-157.

${ }^{160}$ Ibidem, p. 208.

${ }^{161}$ BECARD, op. cit., 2009, p. 79.
} 
Angola, Namíbia, Moçambique e África do Sul. Colocava a visita dentro de um contexto de "pacificação e democratização", além de ter a intenção de desenvolver a Zona de Cooperação do Atlântico Sul. Fernando Henrique teria papel, ainda, em ajudar a convencer o governo dos EUA a reconhecerem o governo do MPLA em Angola, segundo Antonio Patriota ${ }^{162}$.

\subsubsection{Governo Fernando Henrique (1995-2002)}

No período do governo Fernando Henrique, as relações com a África são colocadas em banho-maria, ainda num contexto de crise africana, econômica e política. Em meados da década, a África respondia a apenas $2 \%$ do comércio mundial. Crises políticas ocorriam em Angola, Moçambique, Guiné-Bissau, Serra Leoa, dentre outros. Nesse período foi feita a oficialização da Comunidade dos Países de Língua Portuguesa, em 1996, que, no contexto de crise, serviu como fórum de diálogos. O Brasil, como membro não permanente do Conselho de Segurança da ONU, participou da decisão do estabelecimento de Missão de Paz em Serra Leoa $^{163}$. O Brasil também participava da Missão de Paz da ONU em Angola, que se encontrava em guerra civil desde 1992. Em relação a Namíbia, recém-independente, o Brasil recebeu seu presidente em 1995 e fortaleceu cooperação Sul-Sul nas áreas agrícolas e naval: a Embrapa atuava no norte do país e soldados africanos passavam por formação no Brasil. No final da década, a cooperação se estenderia para as áreas da saúde e educação. Em Moçambique, conforme a pacificação do país se desenvolvia, o Brasil deu mais atenção àquele país, seja em matéria de cooperação técnica, já com a intenção de retomar o projeto de exploração de jazidas carboníferas de Moatize, seja em matéria de comércio ${ }^{164}$.

A presença diplomática, entretanto, diminuía - com remoções de diplomatas e fechamento de representações, na medida que a atenção do governo se virava para os Estados Unidos e a Europa. No âmbito das visitas presidenciais, Fernando Henrique, por outro lado, tinha sua agenda pautada principalmente por compromissos externos, como aponta seu chanceler Lampreia em memorandum de 1995: as viagens de Fernando Henrique ocorreriam por "posses presidenciais, compromissos multilaterais regionais e internacionais, e visitas

\footnotetext{
162 BARRETO, op. cit., 2012, p. 256-258.

${ }^{163}$ Ibidem, p. 430-435.

${ }^{164}$ Ibidem, p. 440-441.
} 
bilaterais" ${ }^{165}$. Fernando Henrique foi à África 4 vezes, visitando África do Sul, Angola e Moçambique, sendo duas dessas visitas para compromissos multilaterais ${ }^{166}$. Ferreira aponta que os chanceleres do governo Fernando Henrique - Luiz Felipe Lampreia e Celso Lafer não fizeram nenhuma viagem de natureza bilateral durante o governo ${ }^{167}$.

Cabe observar também que não houve um incentivo à carreira diplomática no período, considerando que 268 novos diplomatas tomaram posse sob os auspícios de Fernando Henrique $^{168}$. Além disso, 6 representações foram encerradas - Tanzânia (1995), Camarões (1999), Rep. Dem. do Congo (1997), Togo (1997), Tunísia (1999) e Zâmbia (1996) ${ }^{169}$, com a justificativa de pragmatismo na alocação de recursos limitados ${ }^{170}$.

Vários motivos são apontados para isso: tanto a dificuldade em relação à infraestrutura na África quanto a concorrência de empresas europeias, além do desconhecimento mútuo foram tidos como obstáculos para as relações. O governo desestimulou a presença brasileira, deixando de fazer investimentos e concessões a empreendimentos e empresas.

Quanto ao fluxo comercial, este foi desestabilizado com a diminuição das exportações brasileiras e o aumento da importação de petróleo, principalmente no caso da Nigéria ${ }^{171}$. Houve, no período de 1997 a 2002 um leve aumento do fluxo comercial, chegando no auge de US $\$ 5,3$ bilhões em 2001, conforme gráfico abaixo. A balança comercial foi negativa durante todo o período, sendo que as importações tiveram maior crescimento que as exportações, que cresceram apenas nos dois últimos anos do governo Fernando Henrique.

\footnotetext{
165 Idem. P. 399.

${ }^{166}$ Para África do Sul e Angola, Fernando Henrique foi com comitivas de empresários, em 1996. Para Moçambique, foi a Maputo para a III Conferência da CPLP, em 2000. Folha de S. Paulo, 24/11/1996 e 17/07/2000. Em 2002, retornaria à África do Sul para participar da Cúpula Mundial sobre Desenvolvimento Sustentável, em Joanesburgo. http://www.biblioteca.presidencia.gov.br/ex-presidentes/fernando-henriquecardoso/viagens

${ }^{167}$ FERREIRA, Walace. A Política Externa para a África dos governos FHC e Lula: uma análise comparada. Tese UERJ, 2015, p. 198.

${ }^{168}$ FERREIRA. op. cit., p. 120.

$169 \mathrm{http}: / /$ www.itamaraty.gov.br/pt-BR/relacoes-bilaterais.

${ }^{170}$ PIMENTEL, José Vicente de Sá. Relações entre o Brasil e a África subsaárica. In: Revista Brasileira de Política Internacional n. 43 I, 2000, p. 7.

${ }^{171}$ BECARD, op. cit., 2009, p. 127-128.
} 
Gráfico 1 - Fluxo Comercial Brasil-África 1997-2002

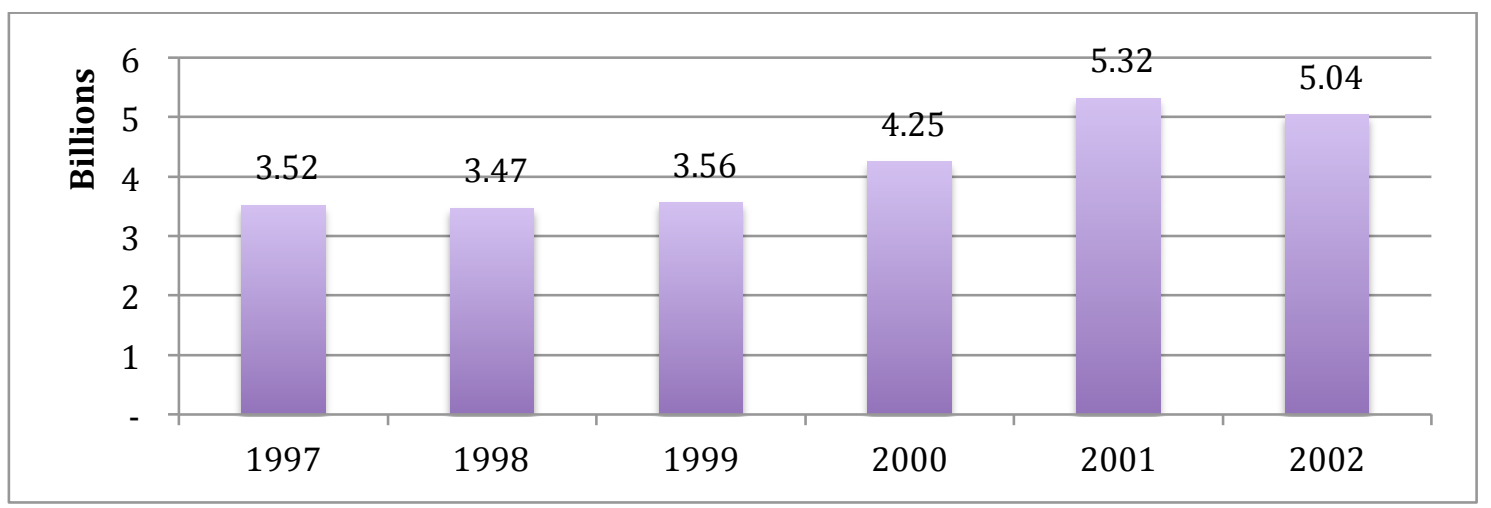

Fonte: Elaboração própria a partir de dados do AliceWeb/Secex.

Houve também, principalmente no segundo mandato de Fernando Henrique, intensificação da cooperação técnica do Brasil para países em desenvolvimento. A maioria dos 133 projetos de cooperação tinha como parceiros países africanos de língua portuguesa, com foco na capacitação de recursos humanos, fortalecimento de infraestrutura técnica e institucional, nas áreas de saúde pública, educação, agricultura, indústria, administração pública, meio ambiente, energia e mineração ${ }^{172}$.

\subsection{Síntese}

A intenção de se desenvolver aqui uma perspectiva histórica das relações entre Brasil e África desde 1960 até a década de 1990 é de visualizar a política externa brasileira para a África como um processo, e, de certo modo, para servir de "prólogo" para a análise mais detalhada da política externa do governo Lula em direção à África. Depois de um período de "banho-maria", a partir dos governos Fernando Collor e Fernando Henrique - apesar de leve incremento nas relações comerciais e cooperativas -, Lula e seu chanceler, Celso Amorim, partem para uma nova revalorização das relações, tanto políticas quanto econômicas. Suas iniciativas acabam por seguir trilhas já pisadas, embora levemente esquecidas.

Desse modo, no período analisado, em relação à política africana, seguimos Fonseca Jr.: existem condicionantes, à política externa, internacionais e nacionais. Quanto àquela, são aspectos sistêmicos, ao levarmos em conta que de 1960 a 1990 a lógica internacional era

\footnotetext{
${ }^{172}$ MRE. Resenha de Política Exterior do Brasil, n. 88, 1o Sem. 2001, p. 164.
} 
ditada pela bipolaridade da Guerra Fria. Quanto a esta, são aspectos de política interna, como orientação da presidência, grupos de apoio político ${ }^{173}$. Neste último, um elemento muito relevante para a política africana brasileira foi a pressão portuguesa de valorização de laços afetivos entre Brasil e Portugal.

À condicionante externa - que a bem da verdade vai um pouco além do fim da Guerra Fria - soma-se também a conjuntura econômica internacional, principalmente nos choques do petróleo e posteriormente a crise da dívida externa. E, internamente, o próprio desenvolvimento econômico brasileiro, cuja capacidade industrial está se desenvolvendo nas décadas de 1960 e 1970, e cuja demanda por petróleo também é crescente. Saraiva, enfim, pontua 4 elementos de aproximação brasileira à África. O primeiro, é a manutenção do projeto nacional-desenvolvimentista, traduzindo a aproximação numa busca por mercados; o segundo é a busca pela garantia de fornecimento de petróleo, dada a vulnerabilidade energética brasileira; o terceiro seria a manutenção de influência na região do Atlântico Sul e, por fim, a busca de novas vinculações aos países de língua portuguesa. Ademais, com as mudanças do cenário internacional, principalmente em relação aos fóruns multilaterais, em alternativa à bipolaridade da Guerra Fria, o continente africano, com diversos novos países, passa a ser fonte de apoio para demandas comuns no diálogo Norte-Sul ${ }^{174}$.

Assim, no período ora analisado, as condicionantes modificam-se, mas a política externa, a grosso modo, busca adaptar-se para manter o desejado grau de autonomia. Nesse sentido que Fonseca Jr. coloca como uma das virtudes da PEI e do Pragmatismo Responsável a coerência do discurso da política externa em relação à África ${ }^{175}$. Entretanto, no caso da PEI, uma condicionante interna seria um duradouro constrangimento, que desaparece justamente no início do governo Geisel: a influência portuguesa. Era completamente inviável para o Brasil seguir com a aproximação com os africanos sem uma mudança, uma ruptura com o relacionamento com o Portugal colonialista, e, também, com a África do Sul racista.

Letícia Pinheiro coloca a ambiguidade como principal característica da política externa brasileira frente à descolonização. Por exemplo, apesar do discurso diplomático a favor da descolonização, quando se tratava das colônias portuguesas, o antigo Tratado de Consulta e Amizade, datado de 1953, era invocado, mostrando alinhamento nas posições dos

\footnotetext{
${ }^{173}$ FONSECA JR., op. cit., 1998, p. 304.

${ }^{174}$ SARAIVA, op. cit. 1994, p. 307-308.

${ }^{175}$ FONSECA JR., op. cit., 1998, p. 343.
} 
dois países. A retórica sobre os vínculos antigos entre Brasil e Portugal vem de antes da década de 1960. O representante brasileiro na ONU, em 1953, legitima a posição colonial portuguesa, pois "a tarefa civilizadora de Portugal nas Américas, África e Ásia se realizou acima dos fatores materiais do colonialismo"176.

Pinheiro, seguindo Rodrigues, aponta como motivos para tanto o grande grupo de pressão no interior da sociedade brasileira, de tradicionais interesses portugueses. Rodrigues afirma que a colônia portuguesa, em São Paulo e no Rio de Janeiro, contava com mais de 105 centros, associações, casas etc. Além de colunas em jornais, diga-se. ${ }^{177}$. Outro motivo não seria outro senão os "laços especiais" e o culto à herança lusitana, uma verdadeira camisa-deforça para a política externa brasileira ${ }^{178}$. Essa cunha só seria retirada com a própria decadência do regime português, em 1974, após a Revolução dos Cravos. Ainda assim, são pelo menos 14 anos que poderiam ter sido melhor aproveitados com uma melhor iniciativa brasileira na questão, como queria Gibson Barboza, que, entretanto, escolheu pelo caminho da mediação, conforme foi visto.

Havia, ainda, o questionamento da viabilidade da África como parceiro comercial questionamento que não deixou de existir nem no período Lula. Muitos buscavam o argumento de que os países africanos seriam concorrentes brasileiros no mercado de bens primários, como café e cacau, ainda mais depois de acordos como o de Lomé, pelo qual ganham preferências nos mercados europeus. Ignácio Rangel, em artigo de 1962, enxerga de outra maneira ${ }^{179}$ : ele defende que o Brasil deveria encarar a África não como competidor, mas como novo mercado, capaz de absorver produtos brasileiros. Percebe que o processo africano de independência é irreversível, e que o Brasil deve agir conscientemente. Entende como injustificado o temor de África se tornar forte concorrente, pois o mercado seria amplo o suficiente para ambos. Como novo mercado, os países africanos estão em processo de desenvolvimento, mas se tornarão mercados para os produtos manufaturados brasileiros.

José Honório Rodrigues afirmou mais de uma vez em seu livro sobre as relações Brasil-África que o Brasil não tinha e não teve uma política africana (principalmente na década de 60). Entretanto, observando desde a década de 1960 até a década de 1990, podemos

\footnotetext{
${ }^{176}$ PINHEIRO, Letícia. Brasil, Portugal e a descolonização africana (1946-1960). In: Contexto Internacional, v. 9 , n. 5, 1989, p. 92 e 106.

${ }^{177}$ RODRIGUES, op. cit., 1982 , p. 387.

${ }^{178}$ PINHEIRO, op. cit., 1989, p. 107.

${ }^{179}$ RANGEL, Ignácio. África e outros novos mercados. In: Tempo Brasileiro, II, dez. 1962.
} 
observar que a África não saiu do olhar brasileiro. Talvez seja o caso de se diferenciar, em diversos períodos, uma politica externa brasileira para a África de uma política africana do Brasil. Considerando-se a partir da descolonização africana, o Brasil esboçaria pela primeira vez, com Quadros e a PEI, uma política africanista, no sentido de, pelo menos no discurso e no sentimento da intelectualidade progressista, haver uma política externa que também abarcasse a afinidade e identificação com a cultura africana. Por outro lado, no imediato pósgolpe de 64, por conta da ideologia da Guerra Fria, as relações fossem mantidas formalmente, sem muito esforço de aproximação, em que pese visitas de autoridades africanas e missões comerciais brasileiras. A partir de Médici, com o chanceler Mário Gibson Barboza, a política africanista começa a ser retomada, mas ainda limitada pelo clima da Guerra Fria e da pressão portuguesa. O governo Geisel seria um mais um marco na política africanista, já sem a pressão portuguesa em relação às antigas colônias, com o reconhecimento de Angola e o afastamento do regime racista da África do Sul. A década de 1980 seria, a princípio uma continuação dessa linha de Geisel, mas com a crescente crise tanto africana quanto brasileira, caminharia mais uma vez, a partir da década de 1990, para uma relação mais de observador da África do que participativo. Cristovam Buarque, em 1999, critica a política externa para a África justamente nessa linha: "nossa política externa se limita a manifestar preocupações". Lampreia, o chanceler de então, responde que o Brasil está presente na África nas missões de paz e estabelecendo cooperações técnicas com os países africanos ${ }^{180}$. No entanto, a presença brasileira se dá mais via Nações Unidas do que ações efetivas, que são, de fato, prejudicadas pelos contextos conflitivos de vários países. Mas não muda a crítica de Buarque, a política externa brasileira para a África nesse momento não busca afinidades ou identificação, mas confere mais importância à participação brasileira em fóruns multilaterais, nos quais discute ações para o continente africano.

Portanto, as relações brasileiras desde a descolonização até o fim da década de 1990 passam, de fato, por intensidades diferentes, mas em nenhum momento são abandonadas. Essas relações, como toda a política externa, são modificadas conforme mudam as condicionantes internacionais, principalmente. Os recuos, silêncios ou rupturas, como dizem alguns autores, podem ser identificados com os momentos de maior ou menor intensidade, ou na diferenciação de uma política para a África e uma política africana.

\footnotetext{
${ }^{180}$ BARRETO, op. cit., 2012, p. 439-440.
} 
O governo Lula, com o chanceler Celso Amorim, irá retomar algumas das iniciativas anteriores para a África, e aprofundá-las: a sua política externa para a África, de todo modo, leva em consideração o processo como um todo da política brasileira para o continente africano. A partir da análise de suas iniciativas e da coerência entre as diversas dimensões dessa política, tentaremos também identificá-la dentro dessa proposta. Essa política será objeto do próximo capítulo.

Ainda, considerando a visão panorâmica da evolução da política externa brasileira para a África construída acima, é possível elaborar um quadro-síntese das relações BrasilÁfrica no período entre 1961 e 2000, conforme abaixo. Considerando as iniciativas de cada governos, procuramos estabelecer algumas medidas de intensidade ao comparar as relações ao longo do tempo. Os momentos de menor aproximação, ou, em outras palavras, com poucas ações e iniciativas, foram considerados de intensidade "fraca", como foi bem visível no primeiro governo do regime militar, com Castelo Branco e Costa e Silva, em contraste com o período anterior; e nos anos 1990, que mostrou relações decrescentes, tanto com Collor/Itamar e com Fernando Henrique, com a diminuição de embaixadas, por exemplo.

Os momentos que tiveram um relativo aumento nas relações foram considerados como de intensidade reduzida-média, como a retomada de princípios da PEI no governo Médici, com o chanceler Gibson Barboza e seu périplo africano, portanto de crescimento em relação ao período anterior; e os governos de Figueiredo e Sarney, que recebem uma relação mais próximo do governo Geisel, mas pelo contexto internacional da década de 1980, tem um sentido de decréscimo nas relações. Os momentos de maiores aproximações são do governo Jânio/Jango, por conta do desenvolvimento da PEI; e do governo Geisel, com o reconhecimento das antigas colônias portuguesas. Consideramos aqui que durante o governo Geisel as relações Brasil-África tiveram intensidade maior no período, pelo fim dos constrangimentos portugueses nas relações com o continente africano. A PEI, em que pese a mudança de prioridade nas relações, não conseguiu quebrar o lobby português, e, consequentemente, transformar o discurso em prática. 
Quadro-síntese das Relações Brasil-África no período 1961-2000

\begin{tabular}{|c|c|c|c|c|c|}
\hline Período & Presidente & $\begin{array}{l}\text { Chanceler } \\
\text { (principais) }\end{array}$ & Aspectos positivos & $\begin{array}{l}\text { Aspectos } \\
\text { negativos }\end{array}$ & Intensidade \\
\hline $\begin{array}{l}1961- \\
1964\end{array}$ & $\begin{array}{l}\text { Jânio } \\
\text { Quadros/João } \\
\text { Goulart }\end{array}$ & $\begin{array}{l}\text { Arinos, } \\
\text { Dantas, } \\
\text { Araújo } \\
\text { Castro }\end{array}$ & $\begin{array}{l}\text { Novo discurso; PEI; } \\
\text { embaixadas, cursos }\end{array}$ & $\begin{array}{l}\text { Nível } \\
\text { retórico, } \\
\text { lobby } \\
\text { português }\end{array}$ & Média \\
\hline $\begin{array}{l}1964- \\
1969\end{array}$ & $\begin{array}{l}\text { Castelo } \\
\text { Branco/Costa e } \\
\text { Silva }\end{array}$ & $\begin{array}{l}\text { Vasco } \\
\text { Leitão, } \\
\text { Juracy } \\
\text { Magalhães }\end{array}$ & $\begin{array}{l}\text { Manutenção de } \\
\text { agendas de visitas }\end{array}$ & $\begin{array}{l}\text { Prioridade } \\
\text { nas relações } \\
\text { tradicionais }\end{array}$ & Reduzida \\
\hline $\begin{array}{l}1969- \\
1974\end{array}$ & Médici & $\begin{array}{l}\text { Gibson } \\
\text { Barboza }\end{array}$ & $\begin{array}{l}\text { Périplo africano, } \\
\text { início de retomada }\end{array}$ & $\begin{array}{l}\text { Nível } \\
\text { retórico, } \\
\text { lobby } \\
\text { português }\end{array}$ & $\begin{array}{l}\text { Reduzida- } \\
\text { média }\end{array}$ \\
\hline $\begin{array}{l}1974- \\
1979\end{array}$ & Geisel & $\begin{array}{l}\text { Azeredo } \\
\text { Silveira }\end{array}$ & $\begin{array}{l}\text { Reconhecimento } \\
\text { Angola/Moçambique }\end{array}$ & $\begin{array}{l}\text { Continuidade } \\
\text { das relações } \\
\text { com Áfr. } \\
\text { Sul/apartheid }\end{array}$ & $\begin{array}{l}\text { Média } \\
(* \text { maior do } \\
\text { período })\end{array}$ \\
\hline $\begin{array}{l}1979- \\
1985\end{array}$ & Figueiredo & $\begin{array}{l}\text { Saraiva } \\
\text { Guerreiro }\end{array}$ & $\begin{array}{l}\text { Aumento de } \\
\text { comércio, acordos }\end{array}$ & $\begin{array}{l}\text { Concentração } \\
\text { nos PALOPs }\end{array}$ & $\begin{array}{l}\text { Reduzida- } \\
\text { média }\end{array}$ \\
\hline $\begin{array}{l}1985- \\
1990\end{array}$ & Sarney & $\begin{array}{l}\text { Abreu } \\
\text { Sodré }\end{array}$ & $\begin{array}{l}\text { Início CPLP, visitas; } \\
\text { criação ABC }\end{array}$ & $\begin{array}{l}\text { Concentração } \\
\text { nos PALOPs }\end{array}$ & $\begin{array}{l}\text { Reduzida- } \\
\text { média }\end{array}$ \\
\hline $\begin{array}{l}1990- \\
1994\end{array}$ & Collor/Itamar & $\begin{array}{l}\text { Rezek, } \\
\text { Amorim, } \\
\text { FHC }\end{array}$ & Consolidação CPLP & $\begin{array}{l}\text { Perda de } \\
\text { prioridade }\end{array}$ & Reduzida \\
\hline $\begin{array}{l}1995- \\
2002\end{array}$ & $\begin{array}{l}\text { Fernando } \\
\text { Henrique }\end{array}$ & $\begin{array}{l}\text { Lampreia, } \\
\text { Lafer }\end{array}$ & $\begin{array}{l}\text { Aumento } \\
\text { comércio, } \\
\text { renegociação de } \\
\text { dívidas, cooperação } \\
\text { técnica }\end{array}$ & $\begin{array}{l}\text { Concentração } \\
\text { Áfr. do Sul e } \\
\text { CPLP }\end{array}$ & Reduzida \\
\hline
\end{tabular}




\section{Capítulo 2 - A Política Externa Do Governo Lula (2003-2010)}

O objetivo principal deste capítulo é analisar a política externa do governo do presidente Luis Inácio Lula da Silva 2003-2010, com foco na política para o continente africano. Considerando que essa política se insere dentro do redirecionamento da própria política externa brasileira, de um eixo Norte-Sul para o eixo Sul-Sul ${ }^{181}$, propõe-se abordar essa política para a África em seus diversos aspectos, aqui denominadas de dimensões, que por sua vez são analisadas com relação às suas esferas de atuação. Com essa abordagem, busca-se também apurar a existência, ou não, de uma relação entre elas - ou seja, se existiu houve diálogo entre elas, uma interação interna, ou se caminharam de forma estanque.

Essas dimensões foram classificadas em 1) política - abordando tanto a esfera multilateral, como a de iniciativas de abertura de embaixadas e de visitas de Estado; 2) cooperativa - analisando a atuação da $\mathrm{ABC}$ na coordenação da cooperação internacional técnica, científica e educacional, oferecida pelo Brasil a diversos países africanos, contando também com entrevistas realizadas nas principais áreas de cooperação 3) econômica envolvendo a esfera comercial, analisando as informações sobre o intercâmbio comercial do período, identificando os principais produtos, parceiros e fluxos, após uma minuciosa coleta de dados; e de investimentos, envolvendo os investimentos diretos brasileiros no continente africano, tanto financiamentos a partir do BNDES quanto de empresas particulares, além de um levantamento dos montantes dos perdões de dívidas externas de países africanos.

A partir de 2003, portanto, o continente africano estaria presente, de forma decisiva e relevante, na formulação da nova política externa brasileira do presidente Lula, sempre acompanhado do chanceler Celso Amorim. Mais exatamente, desde o discurso de posse, como lembra Amorim em uma de suas memórias ${ }^{182}$, pois, ao enviar detalhes da política externa à equipe que formularia o discurso de posse junto a Lula, hesitou e não incluiu a África nos apontamentos. Apesar disso, o discurso final não deixou de citar o continente: "Reafirmamos os laços profundos que nos unem a todo o continente africano e a nossa disposição de contribuir ativamente para que ele desenvolva as suas enormes potencialidades." 183

\footnotetext{
${ }^{181}$ ONUKI, Janina e OLIVEIRA, Amâncio Oliveira. O espaço do IBAS na Política Externa Brasileira. In: LESSA, Antônio e OLIVEIRA, Henrique Altemani. Parcerias estratégicas do Brasil: a dimensão multilateral e as parcerias emergentes. Belo Horizonte: Fino Traço, 2013, p. 15.

${ }_{182}$ AMORIM, Celso. Breves Narrativas Diplomáticas. São Paulo: Benvirá, 2013, p. 141-142.

${ }^{183}$ PRESIDÊNCIA da República. Discurso do Presidente da República. Secretaria de Imprensa e Divulgação, 2003.
} 
O continente africano, nesse período, estaria presente não apenas na dimensão retórica da política externa - que analisaremos no capítulo seguinte, junto com o debate suscitado por essa política - mas também nas práticas do governo Lula. Analisando essas relações BrasilÁfrica como um todo e em perspectiva histórica, em referência aos momentos analisados no primeiro capítulo, a intensidade das relações ocorreu também de forma gradual, atingindo o seu ápice no segundo mandato (2007-2010), como veremos adiante.

Administrativamente, foram feitas mudanças na estrutura regimental do Ministério das Relações Exteriores a partir de junho de 2003, que afetariam as relações externas com a África. Até 2003, o Departamento de África do Itamaraty existia em conjunto com o Departamento de Oriente Médio ${ }^{184}$. A partir do Decreto presidencial 4.759, de 21 de junho de 2003, que alterou a estrutura regimental, o Departamento de África passa a existir como um departamento próprio (DEAF), dentro a Subsecretaria-Geral de Assuntos Políticos, com duas subdivisões, conhecidas como Divisão de África I e II (DAF-I e DAF-II). Também nesse decreto foi prevista a Coordenação-Geral de Ações Internacionais de Combate à Fome (CGFome), ligada à Secretaria Geral, responsável por cooperação humanitária (que será tratada abaixo).

Já a partir dos Decretos seguintes, que também regulamentavam a estrutura regimental, em 2004, 2006 e 2010 ${ }^{185}$, o DEAF recebe mais uma subdivisão, o DAF-III, sendo esta a estrutura até hoje. A Portaria do MRE 212 de 30 de abril de 2008 confirma as mudanças regimentais, prevendo inclusive coordenações-gerais com competências específicas de coordenação de fóruns multilaterais envolvendo países africanos, como a Cúpula América do Sul e Países Árabes (a partir de 2010 a Cúpula América do Sul e África) e o Fórum de Diálogo Índia - Brasil - África do Sul (IBAS) ${ }^{186}$. A divisão de competências é geográfica, considerando ainda que o acompanhamento político da Comunidade dos Países de Língua Portuguesa é feito diretamente pelo DEAF a partir de 2010. O Mapa I abaixo mostra as divisões atuais.

\footnotetext{
${ }^{184}$ Decreto 3.959 de 10 de outubro de 2001.

${ }^{185}$ Decretos 5.032 de 5 de abril de 2004; 5.979 de 6 de dezembro de 2006; e 7.304 de 22 de setembro de 2010.

${ }^{186}$ BRASIL. MRE. Legislação MRE. Brasília: MRE, SGEX, 2008, p. 190.
} 
Mapa 2 - Competências das Divisões de África no Itamaraty

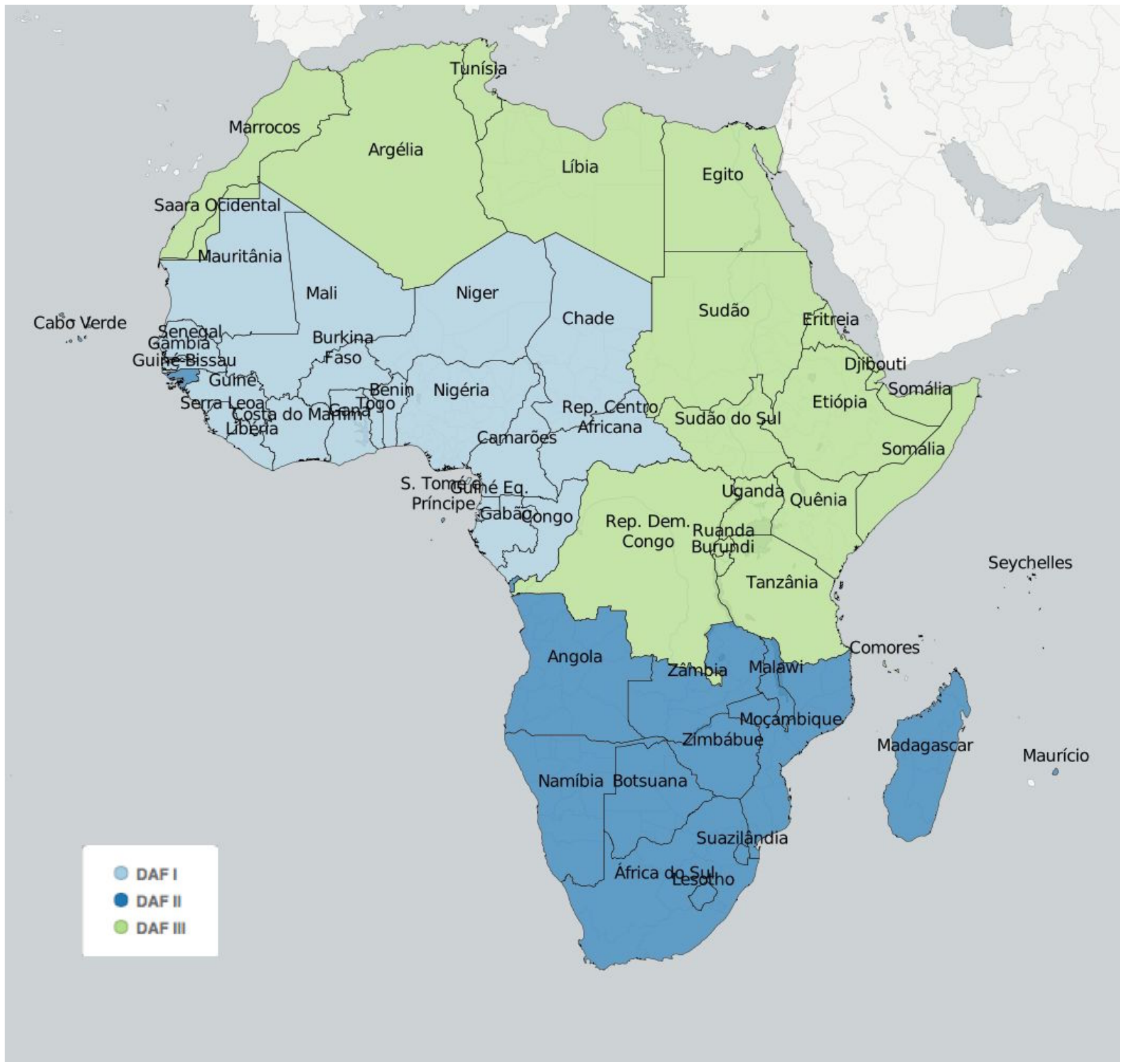

Fonte: Elaboração própria a partir de BRASIL. MRE. Legislação MRE. Brasília: MRE, 2008, p. 191194

Paralelamente às reformas administrativas, Lula e Amorim, empreenderam uma ativa diplomacia presidencial, com visitas de Estado e multilaterais a diversos países africanos em todos os anos do período, provocando também uma onda de reciprocidade, que pode ser verificada no aumento de visitas de chefes de Estado africanos.

As visitas eram comumente acompanhadas de comitivas de empresários e ministros, e muitos países receberam pela primeira vez um chefe de Estado brasileiro. No mesmo sentido, Lula executou uma política de estabelecimento e reabertura de novas representações diplomáticas. Nessa dimensão política, afirma-se que tanto as visitas quanto as embaixadas 
abriam caminho para oportunidades de negócio e estabeleciam um canal de diálogo para receber demandas africanas de cooperação internacional. A seguir, pretendemos verificar essa afirmação ao analisar a relação entre as embaixadas, visitas, cooperação e investimento, a seguir.

Nas entrevistas realizadas sobre a cooperação internacional brasileira, foi diversas vezes observado que a iniciativa das embaixadas teria sido fundamental para o incremento tanto dos projetos de cooperação quanto do aumento do intercâmbio comercial. A análise dos dados comerciais do período levantados na pesquisa torna-se de extrema valia para validação daquela observação. A presença de empresas brasileiras nos países africanos e o destino dos investimentos diretos brasileiros também podem mostrar o quanto a dimensão política orientou as outras áreas.

A hipótese a ser perseguida nesse capítulo, portanto, consiste na afirmação que a política externa brasileira para a África no período Lula foi além de iniciativas anteriores e conferiu mais peso às relações com o continente africano, alterando a natureza dessas relações, com uma vertente mais ativa, de acordo com a ênfase nas relações Sul-Sul. A avaliação dessa política, a partir de seus vários aspectos, num primeiro momento, é relevante para se avaliar como e de que forma essa maior intensidade se apresentou. 


\subsection{Dimensão Política}

Para efeitos deste trabalho, consideramos a dimensão política a partir da interação do Brasil com países africanos, tanto em âmbito multilateral quanto nas relações bilaterais. Essa dimensão foi dividida em 3 esferas, que serão analisadas a seguir. A primeira é a multilateral, na qual o Brasil participa de fóruns de concertação política, que tiveram um incremento de importância justamente no período em tela. Analisaremos primeiro os agrupamentos nos quais o Brasil e a África do Sul participam, como o BRICS e o IBAS; em seguida, iniciativas entre o Brasil e o continente africano, como a CPLP, a ZOPACAS, e a Cúpula América do SulÁfrica (ASA). Ainda nessa esfera, também consideramos a eleição de brasileiros para a chefia de órgãos multilaterais - a Organização das Nações Unidas para Alimentação e Agricultura (FAO, na sigla em inglês), e a Organização Mundial do Comércio (OMC) - como parte da esfera multilateral.

A segunda esfera a ser considerada é a de relações bilaterais, voltadas à da política de visitas de Estado, especificamente para a África, iniciativa que teve bastante ênfase no governo Lula. Em praticamente todos os anos dos dois mandatos Lula foi à países africanos, seja em visitas multilaterais, ou seja, por conta de eventos multilaterais, seja em visitas oficiais de Estado, geralmente era acompanhado por uma comitiva de políticos e empresários.

A última esfera dessa dimensão é a de relações bilaterais de inauguração e reabertura de representações diplomáticas brasileiras em continente africano. No movimento de expandir a presença brasileira no continente (o que ocorreu também em outras regiões do mundo), o período viu elevar o número de embaixadas a tal ponto que o Brasil passou a ser o $4^{\circ}$ país não africano com mais representações na África.

Ao fim, discutiremos a relação entre essas esferas, entre si e no âmbito da política externa brasileira para a África.

\subsubsection{Esfera multilateral}

A aproximação do Brasil com países emergentes foi uma característica aprofundada no período Lula, em sintonia com sua retórica de reconstrução de uma nova ordem mundial. Nesse sentido, foi uma das prioridades do governo Lula, segundo Maria Regina Lima, "uma política externa voltada a impulsionar uma 'nova geografia mundial. ${ }^{187, ", ~ A ~ p o l i ́ t i c a ~ e x t e r n a ~}$

${ }^{187}$ LIMA, Maria Regina Soares de. Brasil e os polos emergentes do poder mundial: Rússia, Índia, China e 
tem pretensão de ser ferramenta e complemento no plano internacional da estratégia de desenvolvimento: ela teria objetivos explícitos de articulação regional com base na complementariedade, na articulação com Índia e África do Sul; e na intenção de conferir instrumentalidade prática ao agrupamento $\mathrm{BRICs}^{188}$. A aproximação com polos emergentes ocorre principalmente por meios políticos-diplomáticos, em grande medida por conta da diferença entre os diversos países, e outros meios, como o econômico-comercial, sendo necessários outros instrumentos além da política externa propriamente dita.

Cabe observar aqui que, apesar de esse tema poder ser abordado como Cooperação Sul-Sul (CSS), no âmbito desse trabalho optamos por colocar a CSS como modalidade da Cooperação Internacional para o Desenvolvimento (CID), tal como usualmente utilizada, e que será devidamente abordada mais adiante, dentro da dimensão cooperativa. Neste trabalho, consideramos a CSS um termo amplo, utilizado para descrever genericamente diversos tipos de relações entre países em desenvolvimento, incluindo as relações entre países emergentes em negociações com os países desenvolvidos ${ }^{189}$. Uma visão mais delimitada da CSS a coloca como um "processo de troca envolvendo quaisquer agentes originários dos países do 'Sul Global"”, este um agrupamento genérico de países em desenvolvimento, sejam de renda média ou renda baixa ${ }^{190}$. De toda forma, entendemos que os agrupamentos servem de plataforma para o lançamento de iniciativas de cooperação na forma de assistência para o desenvolvimento.

No caso do Fórum de Diálogo IBAS (Índia, Brasil e África do Sul), criado em 2003, a iniciativa de congregar países emergentes em um fórum de concertação política exemplifica a nova fase das relações Sul-Sul, pois, anteriormente, como no caso do Movimento dos Não Alinhados (MNA) e do G-77, as coalizões Sul-Sul tinham um aspecto mais defensivo, baseando somente na reforma dos regimes internacionais. O grupo baseou sua parceria estratégica em 3 interesses: 1) compromisso com instituições e valores democráticos; 2) vinculação do combate à pobreza a partir de políticas de desenvolvimento; e 3) fortalecimento das instituições e procedimentos multilaterais contra a instabilidade econômica, política e de

\footnotetext{
África do Sul. In: BAUMANN, Renato. O Brasil e os demais BRICs - comércio e política. Brasília: IPEA, 2010 , p. 160. Outras duas prioridades do governo seriam o compromisso com a inclusão e o aumento da cobertura e do gasto social público; uma política industrial organizada em torno de parcerias público-privada, da coordenação e do financiamento de longo prazo do BNDES

${ }^{188}$ Ibid., p. 160.

${ }^{189}$ BOBIASH, Donald. South-South Aid: how developing countries help each other. Londres: Macmillan Press, 1992 , p. 6.

${ }^{190}$ LEITE, Iara Costa. Cooperação Sul-Sul: Conceito, História e marcos interpretativos. In: Observador On-line, v. 7, n. 3, mar. 2012, p. 4.
} 
segurança. Outras característica que confere novidade ao grupo é o fato de envolver apenas países em desenvolvimento; que são regimes democráticos; e são poderes regionais ${ }^{191}$.

Stuenkel aponta 3 motivações que levaram à institucionalização do grupo. A primeira é a intenção de obter independência e autonomia em relação aos atores tradicionais, como o G-8, por meio da diversificação de parcerias. Essa busca por alternativas aos centros tradicionais de poder seria descrita por Lula ao criticar a pouca atenção dada aos emergentes por parte dos países desenvolvidos. Em 2007, na abertura da II Cúpula do IBAS, Lula afirma que o mecanismo de diálogo entre os países deveria ser modificado para "que nossa voz tenha influência real no tratamento dos grandes temas mundiais. De pouco vale sermos convidados para a sobremesa no banquete dos poderosos. ${ }^{192}$ " A segunda motivação seria para melhorar o processo de socialização entre as potências emergentes, trocando boas práticas e identificando áreas de cooperação. A terceira seria aumentar o poder político nas negociações internacionais, trabalhando em conjunto com outros países do Sul Global, e desse modo juntar forças para levar adiante uma agenda de reformas das políticas globais ${ }^{193}$.

A origem da aproximação do grupo pode ser traçada no encontro entre os presidentes de cada país às margens da reunião do G-8, ocorrida em junho de 2003, em Evian, França, evento para o qual eles foram convidados na condição de observadores. A primeira articulação foi iniciativa do então presidente sul-africano, Thabo Mbeki, que já havia manifestado a intenção de criar um "G-8 do Sul", e conversado com Brasil, Egito, China, Índia, México, Nigéria e Arábia Saudita. O evento do G-8, com a presença de chefes de Estado, foi então a oportunidade de cristalizar as ideias já apresentadas, ocorrendo em junho do mesmo ano a formalização do grupo por meio da Declaração de Brasília. Os temas dominantes no início do grupo foram a reforma do Conselho de Segurança da ONU e a cooperação trilateral como ferramenta para o desenvolvimento econômico e social. ${ }^{194}$

Diferentemente de outras coalizões, o Fórum IBAS caracteriza-se por ser também um arranjo cooperativo ${ }^{195}$, estruturado em 3 eixos principais. O primeiro é a cooperação trilateral em amplo campo de intercâmbios técnicos e comerciais; o segundo é a cooperação com

\footnotetext{
${ }^{191}$ LIMA, Maria Regina Soares de; e HIRST, Monica. A Iniciativa IBAS e a cooperação Sul-Sul: desafios intelectuais e possibilidades políticas. In: novas parcerias. São Paulo: Paz e Terra, $2 \overline{009, \text { p. } 9}$.

192 MRE. Resenha de Política Exterior do Brasil, n. 101, 2o sem. de 2007, p. 134.

${ }^{193}$ STUENKEL, op. cit., p. 17-19.

194 STUENKEL, Oliver. India-Brazil-South Africa dialogue forum (IBSA): the rise of the global south. Nova Iorque: Routledge, 2015, p. 24.

${ }^{195}$ Conforme Maria Regina Soares de Lima, a diferença entre arranjo cooperativo e coalizão se dá que o primeiro envolve a troca entre as partes de bens materiais, simbólicos e ideacionais, e a coalizão implica na articulação de posições comuns em arenas de negociação no plano global ou regional. LIMA, op. cit., 2010.
} 
terceiros países, principalmente aqueles em desenvolvimento; e o terceiro caracteriza uma coalizão, ao prever coordenação de posições na arena multilateral ${ }^{196}$. Ou seja, os dois primeiros eixos representam a face cooperativa do grupo, enquanto o terceiro representa a dimensão geopolítica da articulação entre os países.

A cooperação trilateral com terceiros países em desenvolvimento foi reforçada com a constituição do Fundo IBAS de Combate à Fome e à Pobreza, já em 2004. O Fundo é alimentado por doações anuais de US\$1 milhão de cada membro, e o primeiro projeto foi destinado ao desenvolvimento de agricultura em Guiné-Bissau. Outros projetos seriam aprovados, com Haiti, Burundi, Palestina e Laos ${ }^{197}$. Outro exemplo de cooperação está na área da indústria farmacêutica, considerando complementaridades entre os países, como a indústria indiana de fármacos e a demanda, tanto brasileira quanto sul-africana, de métodos alternativos de tratamento à AIDS. O contencioso das patentes farmacêuticas de medicamentos para AIDS, que envolveu África do Sul, Brasil, Índia e Estados Unidos, no final dos anos 90 refletiu o poder de barganha dos 3 países na negociação multilateral, com o eventual reconhecimento na OMC na legitimidade da demanda ${ }^{198}$. Este caso das patentes farmacêuticas pode inclusive ser considerado uma das áreas de aproximação entre os 3 países que também levariam à criação do IBAS $^{199}$. Nesse sentido, o IBAS se apresenta como mais um mecanismo no qual o Brasil consegue aprofundar suas relações com a África do Sul, um parceiro histórico, e com outros países africanos ${ }^{200}$.

A relevância desse grupo para as relações Brasil-África é múltipla, apesar de não envolver diretamente outros países africanos além da África do Sul. Em primeiro lugar, fortalece a posição da diplomacia brasileira, e da frequente retórica política de Lula, em relação à reformulação da governança global, ao fornecer elementos para o surgimento de novas regras e regimes internacionais. Em segundo, mas no mesmo sentido, o IBAS funciona como uma instância de coordenação de posições para negociações multilaterais, que possam envolver interesses comuns de países africanos. Finalmente, o Fórum permitiu maior aproximação e cooperação com a África do Sul, uma das mais importantes parceiras africanas do Brasil e uma referência dentro do próprio continente, em termos econômicos e

\footnotetext{
${ }^{196}$ Ibid., p. 164.

197 Ibid., p. 165.

${ }^{198}$ LIMA e HIRST, op. cit., p. 13.

${ }^{199}$ OLIVEIRA, Marcelo Fernandes de. Estratégias internacionais e diálogo Sul-Sul no governo Lula: alianças duradouras ou coalizões efêmeras? In: VILLARES, Fábio (org.). Índia, Brasil e África do Sul: perspectivas e alianças. São Paulo: Unesp, 2006, p. 316.

${ }^{200}$ VISENTINI, Paulo Fagundes. A relação Brasil-África: prestígio, cooperação ou negócios? Rio de Janeiro: Alta Books, 2016, p. 81.
} 
geopolíticos ${ }^{201}$.

Diferentemente do IBAS - com características maiores de arranjo cooperativo, como dito acima -, o fórum BRICS constituiu-se como uma coalizão entre 5 países (Brasil, Rússia, Índia, China e África do Sul) para a defesa de posições comuns no cenário financeiro global $^{202}$. A sigla surgiu antes da própria formação do grupo, criada como categoria para descrever grandes países em desenvolvimento, com potencial para serem eixos de mudança econômica global. A ideia foi do economista Jim O’Neill, do Goldman Sachs, no seu estudo de 2001 intitulado "Building Better Global Economic Brics", que levou em conta apenas dados econômicos, uma vez que existem muitas diferenças entre eles. Naquele momento a África do Sul, ainda não havia sido incluída, sendo incorporada em 2011. O termo, portanto, estava inicialmente circunscrito ao mundo financeiro ${ }^{203}$. E à semelhança do IBAS, a aproximação dos países se afasta das antigas coalizões "terceiro-mundistas", e também foi recebida com ceticismo por analistas.

A aproximação como grupo ocorreu, no entanto, apenas a partir de 2006, às margens da Assembleia Geral da ONU, quando os chanceleres de cada país se encontraram para discutir temas em comuns. Em maio de 2008, houve uma primeira reunião fora do âmbito da ONU, em Ecaterimburgo, na Rússia, resultando no primeiro comunicado conjunto, que previa uma reunião de Cúpula em 2009, na mesma cidade $^{204}$.

Naquele momento, já no contexto da crise financeira mundial, os quatro países ainda contavam com taxas expressivas de crescimento econômico, ao contrário dos países desenvolvidos. Os temas tratados nas reuniões foram crescendo ao longo do tempo. $\mathrm{Na}$ primeira cúpula foi acordado a reunião periódica dos chefes do executivo, de Chanceleres e Ministros de finanças, cooperação na área de segurança e agricultura. Na Cúpula seguinte, em Brasília, o campo de temas foi ampliado, trazendo reuniões de bancos de desenvolvimento, de empresários e acadêmicos. Em 2011, mais ampliação, contemplando também temas de Saúde, ciência, tecnologia e inovação. Nesse momento, o grupo chama atenção para a necessidade de reforma do Conselho de Segurança da ONU, além de condenar o terrorismo, e fazer declarações referentes ao uso de energia renovável e nuclear, às negociações da Rodada de Doha, da OMC, aos Objetivos do Milênio e à erradicação da fome e pobreza no mundo. No ano seguinte, em Nova Délhi, a Cúpula oficializou a entrada da África do Sul ao grupo. Em

\footnotetext{
${ }^{201}$ ONUKI e OLIVEIRA, op. cit., 2013, p. 29.

${ }^{202}$ LIMA, op. cit., 2010, p. 164.

${ }^{203}$ STUENKEL, Oliver. The Brics and the future of the global order. Londres: Lexington, 2015b, p. 1.

${ }^{204}$ VISENTINI, Paulo Fagundes. A projeção internacional do Brasil: 1930-2012. Rio de Janeiro: Elsevir, 2013, p. 142.
} 
2013, a Cúpula ocorreu na África do Sul, quando foi aprovado o projeto do Arranjo de Contingente de Reservas e da criação do Banco de Desenvolvimento dos Brics ${ }^{205}$.

O BRICS, assim como o IBAS, emerge como uma novidade em relação a antigas coalizões, refletindo também as tendências de transformação do cenário internacional. Não à toa, surge no momento da crise financeira mundial. Outra característica interessante desse grupo é o seu caráter informal, pois não conta com tratado constitutivo ou secretariado. A atividade do grupo deriva da vontade política dos Chefes de Estado e de Governo, adotando uma declaração e um plano de ação a cada cúpula. A demanda dos países do BRICS por mais representatividade no cenário de governança financeira global resultou numa maior preeminência do G-20, que congrega outras economias desenvolvidas e em desenvolvimento ${ }^{206}$.

A criação de um banco de desenvolvimento dos BRICS, chamado Novo Banco de Desenvolvimento (NBD), outra iniciativa inovadora, parte da preocupação de alternativas de financiamento em infraestrutura para países em desenvolvimento. A partir de estudos de grupos de trabalho do BRICS, observou-se a existência de necessidades de financiamento não contempladas em países em desenvolvimento. O NBD seria então uma instituição complementar, ao lado do Banco Mundial, do Banco Africano de Desenvolvimento, entre outros, aberta a países não membros do grupo. O novo banco entrará em vigência após a ratificação de todos os países membros. Ao lado do NBD, outra iniciativa do grupo é o Arranjo Contingente de Reservas (ACR), cujo objetivo é fornecer linhas adicionais para os BRICS em caso de dificuldades nos balanços de pagamentos. Essa iniciativa tem ligação com a demanda do grupo em relação a uma coordenação macroeconômica mais intensa das maiores economias, a fim de garantir estabilidade financeira e garantir ambiente mais sustentável para o desenvolvimento ${ }^{207}$.

A importância do BRICS para as relações Brasil-África, assim como no caso IBAS, está no possível fortalecimento tanto do discurso quanto da posição do Brasil em termos da demanda de reconfiguração do cenário internacional, ao colocá-lo no centro das discussões e negociações com os principais países. As iniciativas do NBD e do ACR, apesar de extrapolar o período aqui tratado, quando consolidadas, podem futuramente assumir um protagonismo internacional e torna-se mais uma alternativa para países em desenvolvimento.

\footnotetext{
${ }^{205}$ BAUMANN, Renato. BRICS: Oportunidade e desafio para a inserção internacional do Brasil. In: et al. BRICS: estudos e documentos. Brasília: FUNAG, 2015, p. 25-27.

${ }^{206}$ DAMICO, Flávio. Antecedentes: do acrônimo de Mercado à concertação politico-diplomática. In: BAUMANN, Renato et al. BRICS: estudos e documentos. Brasília: FUNAG, 2015, p. 68-70.

${ }^{207}$ Ibid., p. 71-73.
} 
A Zona de Paz e Cooperação do Atlântico Sul (ZOPACAS) foi mais uma iniciativa de aproximação do Brasil com países africanos, num contexto geopolítico de defesa e desmilitarização. A proposta da ZOPACAS, de iniciativa brasileira, ocorreu ainda no contexto de Guerra Fria, diante da revitalização de teses de defesa da região das ameaças soviéticas, ainda na década de 1970, com o crescimento de movimento de independência de tendências marxistas. O Brasil rechaçava a criação da Organização do Tratado do Atlântico Sul (OTAS), e na década de 80 trabalhou para apresentar um projeto de desmilitarização do Atlântico Sul. $\mathrm{Na}$ perspectiva do MRE, a região era um local de interesses cooperativos e não deveria estar submetido a influências militares estrangeiras ou regionais ${ }^{208}$.

O Brasil então apresentou proposta na Assembleia Geral da ONU, de 1986, com o apoio principal da Nigéria, tratando da criação de uma zona de paz e cooperação, com o intuito de aproximação dos países ribeirinhos do Atlântico Sul. A proposta foi aprovada pela Resolução 41/11, com oposição da África do Sul - que tinha interesses nucleares à época - e dos Estados Unidos ${ }^{209}$. A resolução põe fim à ideia de um pacto militar na região. A iniciativa não pretendia criar um organismo regional, mas sim promover, aprofundar e ampliar o diálogo político e cooperativo entre os países banhados pelo Atlântico, com objetivos de desenvolvimento econômico e social, proteção ao meio ambiente e à paz e à segurança na região ${ }^{210}$.

No contexto recente, a ZOPACAS está baseada na preservação dos direitos soberanos dos Estados da região, no que diz respeito ao aproveitamento dos recursos marítimos. Depois de um período de inatividade, houve cúpulas em Angola (2007) e Montevidéu (2013), ambas com propostas de revitalização da iniciativa. Celso Amorim, já como ministro da Defesa, reafirmou em 2013 que a Zona não é uma aliança militar contra um inimigo comum, mas uma iniciativa para promover paz e cooperação com os países do entorno do Atlântico. Mas o componente geopolítico não foi deixado de lado, pois o aprofundamento das relações nesse contexto seriam para evitar um vazio de poder que poderia atrair potências estrangeiras. Essa afirmação faz sentido pois o Atlântico Sul aumentou sua importância para a economia brasileira, tanto pela ampliação da plataforma marítima brasileira, quanto pela descoberta das

\footnotetext{
${ }^{208}$ PENHA, Eli Alves. Relações Brasil-África e geopolítica do Atlântico Sul. Salvador: EDUFBA, 2011, p. 179 e 186.

${ }^{209}$ Ibid., p. 186.

${ }^{210}$ MOURÃO, Fernando A. A. e OLIVEIRA, Henrique Altemani. Política Africana no Brasil. In: ALBUQUERQUE, José A. Guilhon. Sessenta anos de política externa brasileira: o desafio geoestratégico. São Paulo: Annablume, 2000, p. 329-330.
} 
reservas do pré-sal, e ainda por ser o local de maior parte das rotas comerciais envolvendo o comércio exterior brasileiro, com especial destaque para o comércio de petróleo ${ }^{211}$.

A discussão sobre a revitalização da Zona já estaria presente na primeira Cúpula América do Sul-África, em 2006. Com a reunião em 2007 em Luanda, um Plano de Ação foi elaborado, prevendo procedimentos para o estabelecimento de um Comitê Permanente e Reuniões Ministeriais. Além disso, previa revisão de mecanismos financeiros nacionais e multilaterais para financiar projetos da Zona e para ativar a cooperação interregional. Esse movimento vai de acordo com a agenda do BRICS e IBAS, proporcionando pontos de convergência entre os fóruns ${ }^{212}$.

A relevância para as relações Brasil-África são mais evidentes no campo da cooperação em defesa, e reflexo disso foi a assinatura, entre 2003 e 2010, de vários acordos de cooperação nessa áreas com países africanos, como África do Sul, Angola, Moçambique, Namíbia, Guiné Equatorial, Nigéria e Senegal. A consolidação da ZOPACAS pode servir como mais uma plataforma para iniciativas de cooperação e aprofundamento das relações bilaterais $^{213}$.

A Cúpula América do Sul-África (ASA, ou, às vezes, AFRAS) foi sugerida em 2005, a partir de uma conversa entre Lula e o presidente da Nigéria, nos moldes da Cúpula América do Sul-Países Árabes (ASPA). Foi uma tentativa de aproximação conjunta de dois pilares da política externa brasileira - a ênfase dos princípios multilaterais e a busca de uma sociedade internacional mais justa -, em âmbito econômico, político e cultural, além de congregar também representantes da Unasul e da União Africana. A Cúpula ocorreu duas vezes no período Lula, em 2006 em Abuja, Nigéria, com os 65 países das regiões, criando também o Fórum de Cooperação América do Sul-África (ASACOF). A Declaração de Abuja exortava a cooperação multilateral, em campos como da paz e segurança, democracia e direitos humanos, comércio e investimento, desenvolvimento e indústria, entre outros. No Plano de Ação de Abuja, estava previsto um encontro de cúpula a cada dois anos. Em 2009 ocorreu a segunda Cúpula, em Isla Margarita, Venezuela. A Declaração de Nueva Esparta reafirmou compromissos e apontou para a necessidade da reforma do Conselho de Segurança da ONU, a luta contra o tráfico de drogas, a promoção da paz, além de também reafirmar a luta contra a fome e pobreza. Uma terceira ocorreria na Líbia, em 2011, mas foi adiada por conta do

\footnotetext{
${ }^{211}$ ABDENUR, Adriana e SOUZA NETO, Danilo M. O Atlântico Sul e a cooperação em defesa entre o Brasil e a África. In: NASSER, Reginaldo Mattar. O Brasil e a segurança no seu entorno estratégico: América do Sul e Atlântico Sul. Brasília: IPEA, 2014, p. 221 e 230.

${ }^{212}$ KORNEGAY, Francis. África do Sul, Atlântico sul e a equação IBAS-BRICS: o espaço transatlântico em transição. In: Austral, v.2, n. 3, 2013, p. 95.

${ }^{213}$ VISENTINI, op. cit., 2016, p. 113.
} 
conflito ali iniciado, que terminou com a queda do governo de Muammar Kadafi. A cúpula ocorreu apenas em 2013, na Guiné Equatorial, com ênfase no tema da cooperação Sul-Sul ${ }^{214}$. Até o final do período, a Cúpula funcionou com 8 grupos temáticos.

Outro encontro foi a II Conferência de Intelectuais da Diáspora Africana (CIAD), ocorrida em Salvador, no ano de 2006. A proposta de sediar o evento surgiu durante conversa entre Lula e o presidente senegalês. Lula utilizou o espaço para mais uma vez justificar a aproximação com bases na dívida histórica brasileira e na luta conjunta contra a pobreza, e valorizar os laços históricos entre Brasil e África ${ }^{215}$.

Um importante fórum de diálogo é a Comunidade de Países de Língua Portuguesa (CPLP). A criação da CPLP teve como antecedente o I Encontro dos Chefes de Estado e Governo de Língua Portuguesa, ocorrido em 1989, em São Luis do Maranhão. Nesse momento, foi criado o Instituto Internacional da Língua Portuguesa (IILP), que seria o embrião da comunidade. Em 1996, durante o governo Fernando Henrique, a CPLP foi, enfim, institucionalizada. O caráter inicialmente cultural e linguístico, de difusão e promoção da língua portuguesa, eventualmente dividiria espaço com outros dois eixos, quais sejam, a concertação político-diplomática e a cooperação internacional. Ao fim do período Lula, a CPLP contava com maior grau de institucionalização, com reuniões periódicas em diversos setores a nível ministerial, como agricultura, defesa, saúde, meio ambiente, entre outros.

A CPLP chama atenção de países africanos não lusófonos, tendo Senegal e Suazilândia como observadores. A União Africana e a Comunidade Econômica dos Estados da África Ocidental (CEDEAO) têm a língua portuguesa como línguas oficiais, contribuindo para a difusão da língua portuguesa e do interesse na comunidade. A CPLP serve também de local privilegiado para a cooperação técnica, que será analisada adiante. Além disso, a comunidade permite a coordenação entre os membros em foros multilaterais.

A atuação brasileira nesse período, nos diversos fóruns aqui analisados, contribuiu para duas vitórias relevantes da diplomacia brasileira, que foram as eleições de brasileiros para as chefias da Organização para Alimentação e Agricultura da ONU (FAO) e da Organização Mundial do Comércio, em 2011 e 2013, respectivamente. Apesar de terem ocorrido após o recorte temporal deste trabalho, esses resultados são reflexo da política empreendida nesse período. José Graziano, um dos idealizadores do programa Fome Zero, foi eleito com margem mínima, 92 a $88^{216}$, após intensa campanha realizada pelo então chanceler

\footnotetext{
${ }^{214}$ VISENTINI, op. cit., 2016, p. 116-117.

${ }^{215}$ MRE. Resenha de Política Exterior do Brasil, n. 96, 2005, p. 37.

${ }^{216}$ FAO. Verbatim Records of Plenary Meetings of the 37th Conference, 2011.
} 
Antonio Patriota. Os votos para eleição da FAO são secretos, necessitando maioria simples para a eleição; considerando que os membros da FAO são praticamente os mesmos da ONU e todos os países africanos são membros, é possível dizer que o apoio africano foi fundamental na eleição de José Graziano em 2011. Já contando com apoio de muitos países africanos, como os da CPLP, Patriota conseguiu reunir, entre os turnos da votação, o G-77, e logrou o apoio da Indonésia, que tinha candidato no primeiro turno da disputa. Os argumentos de convencimento basearam-se nas iniciativas recentes brasileiras de combate à fome e o incremento da cooperação Sul-Sul ${ }^{217}$. Nas discussões em torno da votação, o nome do presidente Lula foi citado pelo representante da África do Sul, colocando-o como um fiador dessa campanha ${ }^{218}$.

A eleição do diretor geral da OMC tampouco ocorreu facilmente, e foi simbólica por ser a primeira vez que um candidato de um país emergente aparece vitorioso, numa organização multilateral muitas vezes vista como o espaço privilegiado dos países desenvolvidos. Roberto Azevedo, diplomata brasileiro representante na OMC desde 2008, concorreu contra um candidato mexicano, preferido pelos países em desenvolvimento. A União Europeia, pouco antes da votação, havia declarado que votaria em bloco no candidato mexicano, levando 28 votos, cerca de um quinto do total ${ }^{219}$. O MRE contabilizava cerca de 93 votos pro candidato brasileiro, após longa campanha, envolvendo desde de ligações a visitas, mobilizando extensa rede diplomática, da Ásia e África ${ }^{220}$. Ao fim, Azevedo conseguiu a maioria necessária, cerca de 89 votos, contando com o apoio dos países africanos e da maioria dos países em desenvolvimento, incluindo o apoio unânime dos BRICS ${ }^{221}$.

Outro esforço brasileiro para aproximar as regiões é de âmbito comercial, qual seja, o Acordo de Comércio Preferencial (ACP) entre o Mercosul e a União Aduaneira da África Austral (SACU). O acordo originalmente era apenas entre África do Sul e Mercosul, com o Acordo Marco celebrado em 2000. A partir de 2003, as negociações passaram a ser com a união aduaneira SACU, que engloba África do Sul, Namíbia, Botsuana, Lesoto e Suazilândia, terminando em 2008. Vários setores comerciais são contemplados, como agrícola, pesqueiro,

\footnotetext{
${ }^{217}$ Valor Econômico. Países em desenvolvimento garantem eleição apertada de Graziano na FAO. 27.06.2011. http://www.valor.com.br/arquivo/895169/paises-em-desenvolvimento-garantem-eleicao-apertadade-graziano-na-fao

${ }^{218}$ Valor Econômico. Lula é o grande fiador da vitória. 27.06.2011. http://www.valor.com.br/arquivo/895173/lulae-o-grande-fiador-da-vitoria

${ }^{219}$ Valor Econômico. UE vota em mexicano e deixa disputa pela OMC mais apertada. 07.05.2013. http://www.valor.com.br/brasil/3113228/ue-vota-em-mexicano-e-deixa-disputa-pela-omc-mais-apertada

${ }^{220}$ Valor Econômico. Itamaraty conta pelo menos 93 votos para eleger brasileiro na OMC. 07.05.2013. http://www.valor.com.br/brasil/3114124/itamaraty-conta-pelo-menos-93-votos-para-eleger-brasileiro-na-omc

${ }^{221}$ The Guardian. Roberto Azevedo's WTO appointment gives Brazil a seat at the top table. 21.05.2013. https://www.theguardian.com/world/2013/may/21/azevedo-head-world-trade-organisation
} 
têxtil, vestuário, autopeças, siderúrgico, químico, eletroeletrônico, entre outros ${ }^{222}$. O Acordo foi enviado para ratificação brasileira em 2010, mas por problemas de tradução do documento original, o mesmo teve de ser revisado, e voltou para ratificação apenas em 2015, sendo aprovado apenas em 18 de setembro de $2015^{223}$. Foi o primeiro acordo extrarregional do Mercosul. Na mesma esteira, o Mercosul celebrou com o Egito um Acordo de Livre Comércio, em agosto de 2010. Do mesmo modo, apenas em 2015 o Acordo seguiu para o Congresso para ratificação, que ocorreu em 9 de outubro de $2015^{224}$.

O âmbito multilateral da política externa brasileira no período não abrange apenas a África, mas as relações Brasil-África estão incluídas nessa esfera. As relações com África do Sul e PALOPs, que eram prioritárias em governos anteriores, se fazem presente aqui. A maior presença brasileira na esfera multilateral reflete a busca de protagonismo no cenário internacional, por parte do Brasil, que envolve mais do que a África, mas ao mesmo tempo também a inclui. A participação brasileira em arranjos cooperativos, nesse sentido, tem duplo significado, fazendo parte da estratégia geopolítica da nova conformação da ordem global, e constrói a imagem da relevância brasileira nessa nova cena, trazendo ainda mais soft power nas relações bilaterais.

\subsubsection{Esfera bilateral: Visitas de Estado}

Um dos elementos mais conhecidos da política externa do presidente Lula foi a prática constante de viagens de Estado. Nesse sentido, Lula deu continuidade à chamada "diplomacia presidencial” de Fernando Henrique Cardoso. Na conceituação de Sérgio Danese, esta seria caracterizada pela "condução pessoal de assuntos de política externa, fora da mera rotina ou das atribuições ex officio, pelo presidente" 225 . O trabalho de Danese sobre diplomacia presidencial nos fornece elementos que ajudam a enxergar a participação de Lula na formulação da política externa do período, partindo justamente da dimensão política. $O$ autor distingue a mera atuação protocolar, reflexiva, em razão do cargo, de uma atuação pessoal e efetiva na política externa. Nesse sentido, define 4 graus na "diplomacia de cúpula" (nome genérico para a diplomacia presidencial). O grau zero seria a diplomacia exercida pelo presidente sem nenhuma ação fora daquela prevista pelos ritos burocráticos. O primeiro grau seria a ação reflexa, ou reativa, uma resposta a eventos externos. O presidente agiria por

\footnotetext{
${ }^{222} \mathrm{http}: / / \mathrm{www} . d e s e n v o l v i m e n t o . g o v \cdot b r /$ sitio/interna/interna.php?area $=5 \& \mathrm{menu}=2339 \& \mathrm{refr}=405$

${ }^{223}$ Decreto Legislativo do Congresso Nacional n. 200 de 2015.

${ }^{224}$ Decreto Legislativo do Congresso Nacional n. 216 de 2015.

${ }^{225}$ Sérgio Danese. Diplomacia Presidencial. Rio de Janeiro: Topbooks, 1999, p. 51.
} 
provocação. O segundo grau já seria mais ativo, com o presidente se transformando em símbolo e instrumento da política externa. Por fim, o terceiro grau seria uma "diplomacia afirmativa", com o presidente tomando iniciativas, conduzindo a diplomacia com "sua própria sensibilidade e senso de oportunidade" 226 .

Nesses termos, a denominação da política externa de Lula como "ativa e altiva" pelo chanceler Celso Amorim se encaixa na atuação do presidente na condução de sua diplomacia. Em relação às visitas de Lula ao continente africano, sua diplomacia difere de seu antecessor. As viagens de Lula não se pautam apenas por eventos ou estímulos externos. Lula realizou 37 visitas, entre visitas de Estado e visitas multilaterais, em 23 diferentes países. No período todo, fez um total de 258 viagens, ficando a África atrás apenas da América do Sul (59) e da Europa (40). Comparando com todos os presidentes anteriores, desde Figueiredo, o primeiro presidente brasileiro a ir à África, Lula visitou praticamente o dobro de países africanos ${ }^{227}$, além de ter diversificado os destinos, visitando não apenas os parceiros mais tradicionais, como Nigéria e Argélia, e os países de língua portuguesa.

Tabela 2 - Visitas de Estado do Presidente Lula por região

\begin{tabular}{|l|c|c|c|}
\hline \multicolumn{1}{|c|}{ Região } & 2003-2006 & 2007-2010 & Total \\
\hline América do Sul & 28 & 31 & 59 \\
\hline América Central & 4 & 15 & 19 \\
\hline América do Norte & 3 & 4 & 7 \\
\hline Europa & 14 & 26 & 40 \\
\hline África & 18 & 11 & 29 \\
\hline Ásia & 4 & 7 & 11 \\
\hline Oriente Médio & 3 & 5 & 8 \\
\hline Antártida & 0 & 1 & 1 \\
\hline Multilaterais & 29 & 55 & 84 \\
\hline \multicolumn{1}{|c|}{ Total } & 103 & 155 & 258 \\
\hline
\end{tabular}

Fonte: Elaboração própria, a partir de MRE. Visitas internacionais do Presidente Lula e visitas ao Brasil de Chefes de Estado e de Chefes de Governo

\footnotetext{
${ }^{226}$ Idem. P. 63-64.

${ }^{227}$ Figueiredo foi a cinco países, Nigéria, Senegal, Guiné-Bissau, Cabo Verde e Argélia; Sarney foi a Angola; Collor a Angola, Zimbábue, Moçambique e Namíbia; Fernando Henrique a Angola e África do Sul. Wilson Mendonça Júnior. Política Externa e Cooperação Técnica: As relações do Brasil com a África durante os anos FHC e Lula da Silva. Belo Horizonte: Plácido Editora, 2013 (recurso eletrônico) e FERREIRA, Walace. A Política Externa para a África dos governos FHC e Lula: uma análise comparada. Tese UERJ, 2015, p. 122.
} 
As visitas presidenciais podem ter vários motivos e objetivos. Em geral, podem ser colocadas como um gesto político ou de relações públicas; explicitação de diplomacia afirmativa, de acordo com os interesses concretos do visitante; e a finalização de uma negociação que necessita da chancela de alto nível ${ }^{228}$. As viagens de Lula, nesse sentido, se encaixariam na ideia de diplomacia afirmativa, motivadas mais pelos interesses concretos do que por respostas a compromissos internacionais, aumentando desse modo o diálogo político do Brasil com os diversos países africanos.

O presidente Lula visitou a África em todos os anos de seus dois mandatos. A África, junto com a América do sul, como visto na tabela acima, foi posicionada com um dos eixos da política externa do novo governo, com prioridade para as relações sul-sul. Nos discursos oficiais, o discurso culturalista de antes dá espaço - mas não desaparece - a um discurso mais objetivo, com a tentativa de equilibrar um posicionamento tanto idealista quanto realista, deixando evidente os interesses concretos brasileiros. A descrição dessa política externa direcionada à África feita em relatório do Ministério de Relações Externas exemplifica essa postura:

Trata-se de política solidária e humanista, que almeja reduzir assimetrias, promover o desenvolvimento e combater a pobreza. Há, no entanto, ganhos concretos auferidos pelo Brasil em seu relacionamento com a África: o acesso a novos mercados, vantajosas oportunidades econômicas e maior influência em foros multilaterais. Ou seja, o engajamento com a África eleva o perfil internacional do Brasil. (grifo nosso) ${ }^{229}$

Amorim reforça esse ponto, ao dizer que a dimensão econômica-comercial não dita completamente as relações, mas que se busca fortalecer o vínculo político com uma região de ligações históricas e culturais com o Brasil. Nesse sentido, Lula realiza diversos "périplos" no continente africano, em 23 diferentes países, durante 29 visitas de Estado, conforme a tabela 3:

Tabela 3 - Países africanos visitados pelo presidente Lula

\begin{tabular}{|l|r|l|r|l|r|}
\hline África do Sul & 3 & Argélia & 1 & Guiné Equatorial & 1 \\
\hline Líbia & 3 & Botsuana & 1 & Namíbia & 1 \\
\hline Angola & 2 & Burkina Faso & 1 & Quênia & 1 \\
\hline Moçambique & 2 & Cameroun & 1 & Senegal & 1 \\
\hline
\end{tabular}

\footnotetext{
${ }^{228}$ Idem, p. 400.

${ }^{229}$ Ministério das Relações Exteriores. Resumo Executivo do Balanço da Política Externa Brasileira 2003-2010, p. 20 .
} 


\begin{tabular}{|l|r|l|r|l|r|}
\hline Cabo Verde & 1 & Congo & 1 & Tanzânia & 1 \\
\hline Gana & 1 & Egito & 1 & Zâmbia & 1 \\
\hline Nigéria & 1 & Gabão & 1 & Benim & 1 \\
\hline São Tomé e Príncipe & 1 & Guiné-Bissau & 1 & Total de visitas & 29 \\
\hline
\end{tabular}

Fonte: Elaboração própria, a partir de MRE. Visitas internacionais do Presidente Lula e visitas ao Brasil de Chefes de Estado e de Chefes de Governo.

No primeiro mandato, o presidente foi a 18 países, acompanhado de numerosa comitiva de ministros, empresários e parlamentares. Em 2003, no mês de novembro, na sua primeira visita ao continente, Lula vai a 7 países, a saber, São Tomé e Príncipe, Angola, Moçambique, Namíbia e África do Sul, e posteriormente ainda Egito e Líbia. Antes desse momento, em Genebra, Lula havia afirmado, durante a Conferência Internacional do Trabalho, que "Temos um compromisso político, moral e histórico com a África, e com os

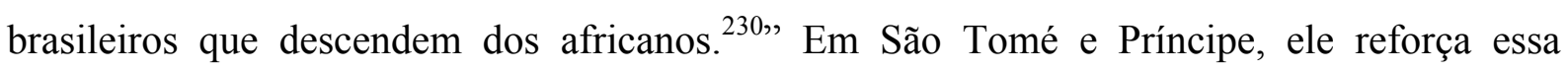
afirmação, deixa evidente a prioridade do continente africano na política externa, e coloca as relações como um dever moral e uma necessidade histórica brasileira ${ }^{231}$.

Em julho de 2004, volta a São Tomé e Príncipe para participar da V Conferência de Chefes de Estado da CPLP, e depois visita Gabão e Cabo Verde. Em abril de 2005, realiza a primeira grande viagem, visitando os países da antiga Costa dos Escravos, local de origem de boa parte dos africanos escravizados destinados ao Brasil, a saber, Camarões, Nigéria, Gana, Guiné-Bissau e Senegal. Em Gana, visitou a mesma comunidade de descendentes de escravizados brasileiros que Raymundo de Souza Dantas visitou na década de 60, o conhecido grupo Tabom. Em Senegal, junto com o ministro da cultura Gilberto Gil, fez uma visita, que repercutiu na imprensa, à ilha de Goreé, onda ainda está de pé a construção na qual os escravizados passavam pela última vez antes de embarcarem, a "Porta do Nunca Mais". Em discurso ao presidente senegalês, o presidente pede perdão ao povo da África pela escravidão no Brasil.

Em fevereiro de 2006, visita 4 países, Argélia, Benim, Botsuana e África do Sul, sendo que neste último participa da Cúpula da Governança Progressista. Depois, em novembro, volta à Nigéria para a I Cúpula África-América do Sul (ASA, também referida como AFRAS), onde reafirma a prioridade da África na agenda brasileira e discute um plano de ação para incrementar a cooperação Sul-Sul. Em outubro de 2007, vai a Burkina Faso,

\footnotetext{
${ }^{230}$ MRE. Repertório de Política Externa: posições do Brasil. Brasília: FUNAG, 2007, p. 157.

${ }^{231}$ MRE. Resenha de Política Exterior do Brasil. N. 93, 2003, p. 186.
} 
República do Congo e Angola, passando na África do Sul para a Cúpula do grupo IBAS. Em 2008 e 2009, apenas duas visitas, uma em cada ano, para visitas multilaterais, a primeira para a XII Unctad em Gana, e depois na Líbia para a Cúpula da União Africana.

Em 2010, no derradeiro ano do mandato, faz seu último périplo africano, indo primeiro a Cabo Verde, para a cúpula Brasil-CEDEAO (Comunidade Econômica dos Estados da África Ocidental); em seguida visitando Guiné Equatorial; Quênia; Tanzânia; Zâmbia; e África do Sul, oportunidade na qual aproveita para lançar a Copa do Mundo de 2014, que viria a ser realizada no Brasil.

Tabela 4 - Visitas de Estado e Multilaterais por ano e destino

\begin{tabular}{|c|c|c|}
\hline 2003 & & \\
\hline Visitas de Estado & $\begin{array}{l}\text { São Tomé e Príncipe, Angola, Moçambique, Namíbia, } \\
\text { África do Sul, Egito, Líbia }\end{array}$ & 7 \\
\hline 2004 & & \\
\hline Visitas de Estado & Gabão, Cabo Verde & 2 \\
\hline Visita Multilateral & $\begin{array}{l}\text { São Tomé e Príncipe }-\mathrm{V} \text { Conferência de Chefes de } \\
\text { Estado da CPLP }\end{array}$ & 1 \\
\hline 2005 & & \\
\hline Visitas de Estado & Camarões, Nigéria, Gana, Guiné-Bissau, Senegal & 5 \\
\hline 2006 & & \\
\hline Visitas de Estado & Argélia, Benin, Botsuana, África do Sul & 4 \\
\hline Visita Multilateral & $\begin{array}{l}\text { África do Sul - Cúpula da Governança Progressista; } \\
\text { Nigéria - I Cúpula África - América do Sul (AFRAS) }\end{array}$ & 2 \\
\hline 2007 & & \\
\hline Visitas de Estado & Burkina Faso, Rep. Congo, Angola & 4 \\
\hline Visita Multilateral & África do Sul - Cúpula IBAS & 1 \\
\hline 2008 & & \\
\hline Visitas de Estado & Moçambique & 1 \\
\hline Visita Multilateral & Gana - XII Unctad & 1 \\
\hline 2009 & & \\
\hline Visitas de Estado & Líbia (Trípoli e Sirte) & 2 \\
\hline Visita Multilateral & Líbia - Cúpula da União Africana & 1 \\
\hline 2010 & & \\
\hline
\end{tabular}




\begin{tabular}{|l|l|c|}
\hline Visitas de Estado & $\begin{array}{l}\text { Guiné Equatorial, Quênia, Tanzânia, Zâmbia, África do } \\
\text { Sul }\end{array}$ & 5 \\
\hline Visita Multilateral & $\begin{array}{l}\text { Cabo Verde - Cúpula Brasil-CEDEAO; África do Sul - } \\
\text { Lançamento Copa do Mundo 2014 }\end{array}$ \\
\hline $\begin{array}{l}\text { Total Visitas de } \\
\text { Estado }\end{array}$ & & 29 \\
\hline $\begin{array}{l}\text { Total visitas } \\
\text { Multilaterais }\end{array}$ & & 8 \\
\hline
\end{tabular}

Fonte: Elaboração própria, a partir de MRE. Visitas internacionais do Presidente Lula e visitas ao Brasil de Chefes de Estado e de Chefes de Governo

O chanceler Amorim também viajou inúmeras vezes ao continente no mesmo período, mais precisamente 67 vezes, em visita a 31 países $^{232}$. Além das viagens em que acompanha o presidente, o chanceler participava de reuniões e eventos oficiais, representando o Brasil em nível ministerial.

Refletindo o princípio da reciprocidade, houve um aumento significativo das visitas de chefes de Estado e chanceleres africanos ao Brasil, considerando visitas bilaterais, de Estado, além das visitas multilaterais:

Tabela 5 - Visitas de Chefes de Estado africanos

\begin{tabular}{|l|r|l|l|l|r|}
\hline Cabo Verde & 6 & S. Tomé e Príncipe & 2 & Malauí & 1 \\
\hline África do Sul & 4 & Argélia & 1 & Mali & 1 \\
\hline Guiné-Bissau & 3 & Benin & 1 & Marrocos & 1 \\
\hline Moçambique & 3 & Burkina Faso & 1 & Mauritânia & 1 \\
\hline Senegal & 3 & Cameroun & 1 & Rep. Congo & 1 \\
\hline Angola & 2 & Djibouti & 1 & Serra Leoa & 1 \\
\hline Botsuana & 2 & Gâmbia & 1 & Uganda & 1 \\
\hline Guiné Equatorial & 2 & Gana & 1 & & \\
\hline Namíbia & 2 & Libéria & 1 & Total de países & 27 \\
\hline Nigéria & 2 & Líbia & 1 & Total de visitas & 47 \\
\hline
\end{tabular}

Fonte: Elaboração própria, a partir de MRE. Visitas internacionais do Presidente Lula e visitas ao Brasil de Chefes de Estado e de Chefes de Governo

Como dito acima, Lula deu continuidade à prática de visitas de Estado de Fernando Henrique, que no seu governo, fez no total 104 viagens $^{233}$, sendo, como dito acima, 4 para a África, e com concentração na América do Sul, com cerca de 40\% da viagens. Segundo

\footnotetext{
${ }^{232}$ Nedilson Jorge. A África na agenda econômica do Brasil. CEBRI, 22 de novembro de 2011. No Resumo Executivo elaborado pelo MRE, consta 66 viagens a 25 países, p. 20.

${ }^{233}$ Walace Ferreira. Op cit, p. 124.
} 
Danese, essa diplomacia de viagens não era uma prática nova. Desde o governo Geisel teria havido um grau de inflexão na "diplomacia presidencial”, utilizando as visitas presidenciais como instrumento de alavancas diplomáticas, com uma preparação prévia e também um "atento follow up". Tanto com Fernando Henrique quanto com Lula apresentam similaridades nessa prática, na medida que a formulação e condução da política externa teria participação pessoal do presidente. No caso das viagens de Lula, parece haver uma vinculação com as linhas formuladas para a política externa: "são parte de um projeto, de uma utilização verdadeiramente instrumental das visitas, algo incomum na história diplomática brasileira", não sendo apenas reações ou retribuições, gestos de amizade ou oportunidade ${ }^{234}$. Figueiredo, curiosamente, ostenta a marca de ser o primeiro presidente brasileiro a visitar o continente africano. Afinal, Lula utiliza a diplomacia de visitas ostensivamente em relação à África.

A importância desse aspecto - a diplomacia das visitas - na política externa de Lula deve ser ressaltada pelo acalorado debate na opinião pública frente a iniciativa de aproximação com a África. Tanto a opinião pública quanto a política interna, segundo Danese, são partes fundamentais da diplomacia presidencial. Esta reage a posições da opinião pública ou tenta convencê-la da importância de determinada ação ou posição na esfera internacional $^{235}$. No caso de Lula e da política externa para a África, esta não foi reativa - não resultou de um evento externo, como uma conferência - e enfrentou a oposição da grande mídia, considerando aqui a mídia impressa, que no geral criticava duramente essa política, como veremos mais adiante, no capítulo 3. Lula vai além da pressão dessa opinião pública, colocando o continente africano como linha da política externa desde o discurso de posse, em 2003, e segue à risca sua "diplomacia presidencial" apesar das constantes críticas da mídia impressa, que ocorrem do início ao fim do período. Celso Amorim reflete esse argumento de que a política africana de Lula não esteve em discussão ou foi resposta à posição da opinião pública - quando relata que a aproximação com a África não era em si um processo complexo, com parceiros ou adversários estrangeiros, nem uma iniciativa nova. A dificuldade estava "principalmente com a opinião pública brasileira - ou melhor, com os chamados "formadores de opinião". Era preciso superar resistências e mobilizar uma boa vontade existente, porém difusa, em nossa sociedade. ${ }^{„ 236}$ Esse debate com a opinião pública brasileira, em relação à aproximação com a África será tratada mais detalhadamente o próximo capítulo.

\footnotetext{
${ }^{234}$ Danese, p. 355.

${ }^{235}$ Idem, p. 90.

${ }^{236}$ Amorim. Op. cit. p. 141.
} 


\subsubsection{Esfera bilateral: Abertura de Embaixadas}

$\mathrm{Na}$ esteira da diplomacia de visitas, o governo Lula também estabeleceu uma política de abertura de postos diplomáticos na África, praticamente em todos os anos, com exceção de 2009 (ano de menor intensidade, quando ocorreu apenas uma visita de Lula ao continente). A abertura de embaixadas e representações pode ser, assim, considerada como parte da diplomacia presidencial, e se encaixa na diplomacia afirmativa de Lula. Cabe notar que em 6 casos de abertura de postos, o país recipiente havia recebido no ano anterior ou no mesmo ano uma visita de estado, e em outros 4 casos os países haviam recebido visitas anteriormente. Desse modo, a abertura de representações pode ser colocada no que Danese chama de follow up ou mesmo de preparação das visitas presidenciais, oferecendo mais elementos para uma aproximação política dentro dos interesses brasileiros, como assinatura de acordos comerciais e de cooperação, e também diferenciando esse momento de outros, pois coloca a abertura de embaixadas dentro de uma linha diplomática mais ampla, e não como um ato isolado. No Mapa 2, podemos ver em quais países as embaixadas foram estabelecidas e reabertas.

O Brasil mantém relações diplomáticas com todos as 54 nações africanas. Ao início do período Lula da Silva, o Brasil mantinha 16 embaixadas e 2 consulados-gerais (na Nigéria e África do Sul). A partir de 2003, iniciou-se a política de abertura de embaixadas, com a representação em São Tomé e Príncipe. Em 2004, procedeu-se à realocação da embaixada na Nigéria para a nova capital Abuja, enquanto em Lagos manteve-se o consulado geral, e à criação do posto da República Democrática do Congo; em 2005, ocorre a reabertura dos postos da Etiópia (fechado no final da década de 1960), Camarões e Tanzânia; em 2006, a criação das embaixadas de Benin, Guiné Conacri e Guiné Equatorial, Sudão e a reabertura da de Togo; em 2007, criação da representação de Botsuana e reabertura da de Zâmbia; em 2008, as aberturas em Mali, República do Congo e Burkina Faso; e, finalmente, em 2010, as aberturas em Mauritânia, Serra Leoa e Malauí. No total, foram 19 novos postos, sendo 7 reaberturas $^{237}$. Nos outros 17 países sem representação permanente, são responsáveis cumulativamente embaixadores de países vizinhos.

\footnotetext{
${ }^{237}$ A embaixada no Malaui foi instalada em 2011, mas anunciada em 2010.
} 
Mapa 3 - Embaixadas brasileira na África por ano

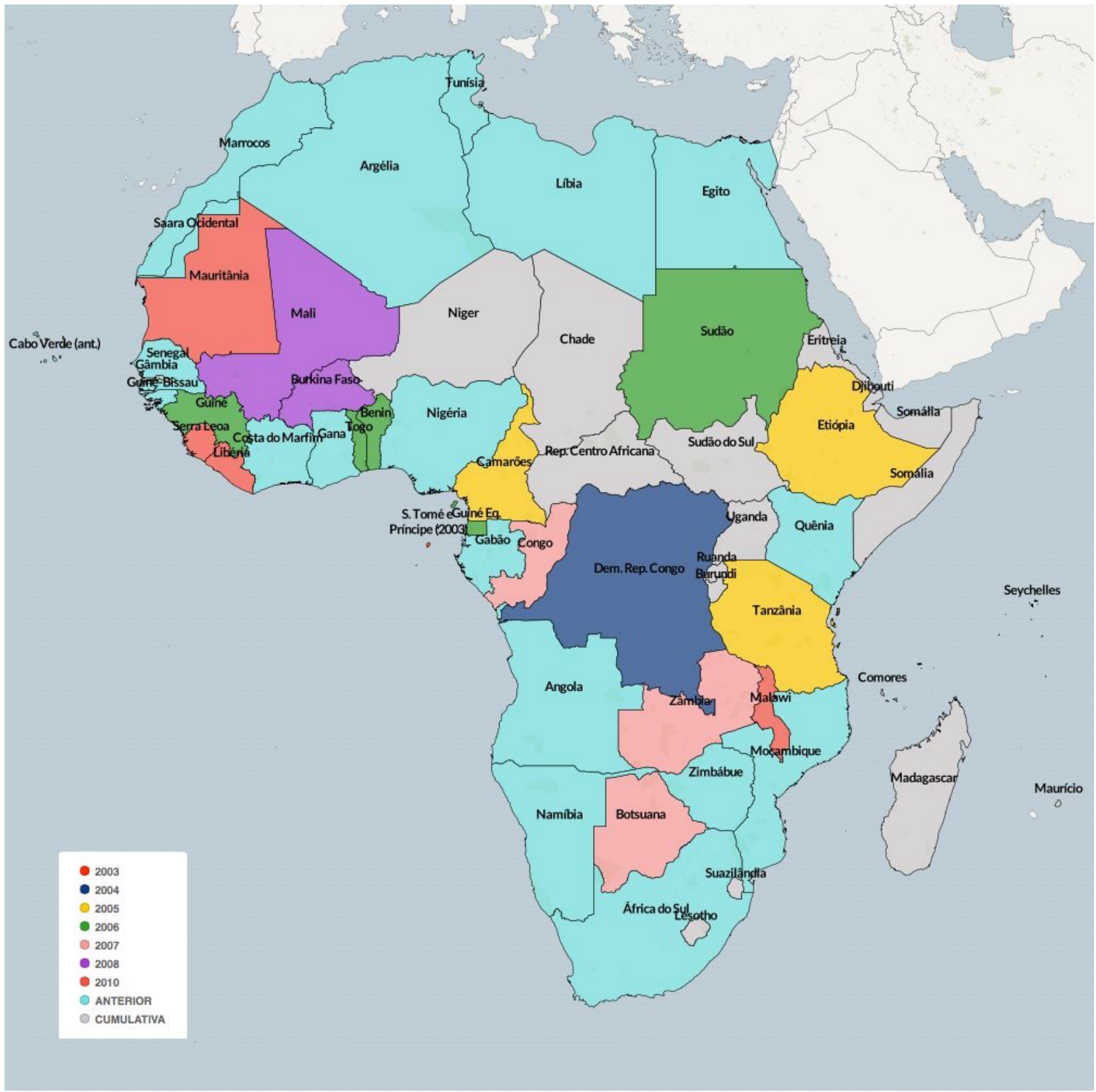

Fonte: Elaboração própria a partir de Nedilson Jorge, 2011.

Dentro do princípio da reciprocidade, 17 países africanos estabeleceram legações em Brasília, a saber: Benim, Botsuana, Burkina Faso, Congo, Etiópia, Guiné-Conacri, GuinéEquatorial, Guiné-Bissau, Mali, Malaui, Mauritânia, Namíbia, Quênia, Sudão, Tanzânia, Zâmbia e Zimbábue ${ }^{238}$. No Mapa 3 podemos ver a disposição geográfica das representações brasileiras, e quais já estavam estabelecidas, os novos postos e as reaberturas. A África 238 Elaboração a partir do sítio do Itamaraty na internet: http://www.itamaraty.gov.br/index.php?option=com_content\&view=article\&id=3663\&Itemid=112\&lang=pt-BR e Nedilson Jorge, 2011. 
setentrional e Meridional são completamente abarcadas pelas legações diplomáticas brasileiras, restando sem representação permanente países centro-africanos, como Somália, Eritreia e Djibuti, Madagascar e Comores, Gâmbia, Lesoto e Suazilândia. Assim, o Brasil passa a ser o país na América Latina com o maior número de representações africanas, mais exatamente trinta e três ${ }^{239}$.

Em relação à presença no continente africano, o Brasil fica atrás apenas dos Estados Unidos, com 49 representações; China, com 48; França, com 46; e África do Sul, com $44^{240}$, mas à frente de outras nações emergentes, como Índia, com 27 e Turquia, com $31^{241}$. A reabertura da embaixada brasileira em Adis Abeba, Etiópia, coincide também com uma aproximação brasileira da União Africana, órgão regional criado em 2002 para estimular a integração política e o desenvolvimento econômico e social do continente, que conta com 53 membros. A União Africana tem sede em Adis Abeba, e desde a reabertura da representação diplomática, a diplomacia brasileira tem acompanhado mais de perto suas atividades. Nesse sentido, o presidente Lula participou como convidado especial em 2009 da XIII Cúpula de Chefes de Estado da União Africana, realizada na Líbia ${ }^{242}$. Em 2013, seria a vez de Dilma ser convidada para as festividades de 50 anos da criação da Organização da Unidade Africana, embrião da atual organização.

Ainda dentro da iniciativa das embaixadas, poderíamos analisar o corpo diplomático brasileiro, ou seja, observar se houve um crescimento de funcionários do MRE em relação ao esforço de aumentar a presença brasileira no continente africano. Como observa Wallace Ferreira, o número de vagas no concurso de admissão à carreira de diplomata aumentou consideravelmente no governo Lula, e consequentemente o número de posses de $3^{\circ}$ secretários. O aumento é expressivo se ainda considerado o alto número de posses de diplomatas durante o governo: $655^{243}$.

Fica evidente que o aumento do corpo diplomático reflete o interesse do governo Lula em fortalecer as Relações Exteriores brasileira, resultado no aumento de representações na África e no Caribe, principalmente. Mas o simples aumento não significa necessariamente que as novas estruturas estejam recebendo novos diplomatas e recursos, de modo a operar de maneira efetiva. Além disso, o aumento do quadro provocou mudanças internas quanto aos sistema de remoções - a lotação dos postos no exterior e no Brasil - e na classificação dos

\footnotetext{
${ }^{239}$ FERREIRA, op. cit., p. 121.

${ }^{240}$ Página de Relações Externa da África do Sul. http://www.dfa.gov.za/foreign/sa abroad/hom.htm . Acesso em 15 de junho de 2016.

${ }^{241}$ FERREIRA, op. cit., p. 119.

${ }^{242}$ MRE. Resumo, p. 21.

${ }^{243}$ FERREIRA, op. cit., p. 120
} 
postos no exterior.

Nesse sentido, analisando as portarias internas referentes às lotações dos postos brasileiros no exterior, podemos verificar que, de 2003 a 2010, o número de postos para diplomatas na África dobrou: de 65 postos em 2003, foi para 130 em 2010, enquanto de oficiais e assistentes de chancelaria - as outras carreiras dentro do MRE - o número passou de 70 em 2003 para 129 em $2010^{244}$. Além da nova diretriz de aumento da presença diplomática brasileira, o crescimento econômico do período Lula beneficiou a ampliação interna do MRE. Ainda assim, isso não significa que todos os postos foram lotados. Segundo informações obtidas no MRE, uma representação necessariamente recebe no mínimo 2 diplomatas, sendo um o embaixador e chefe da missão. E mesmo nesse caso, às vezes o posto do embaixador demora a ser preenchido em virtude dos trâmites legais no Brasil. Além disso, o aumento do número de diplomatas diminuiu o ritmo de ascensão na carreira, e muitos $3^{\circ}$ Secretários escolhem lotações na própria Secretaria de Relações Exteriores, em postos na capital brasileira.

Outra observação que pode ser feita nesse caso é a proporção de postos no exterior por região. Nesse caso, o aumento de postos na África e no Caribe pode ser resultado de uma melhor distribuição de postos no mundo, uma vez que em regiões tradicionais como Europa, América do Norte e América do Sul esses postos já existiam. Ou seja, aquele aumento de postos não ocorre por "motivos ideológicos", mas pela natural expansão diplomática brasileira. Como podemos ver na tabela abaixo, a proporção aumenta mais na África e Caribe, e diminui relativamente pouco nas regiões tradicionais, pelo simples fato de aumentarem os postos no total, e não haver muita possibilidade de expansão nessas regiões (a não ser criação de novos consulados gerais).

Tabela 5 - Distribuição de postos diplomáticos por região 2003 e 2010

\begin{tabular}{|l|l|l|l|l|l|l|l|}
\hline & África & $\begin{array}{l}\text { América } \\
\text { Central } \\
\text { Caribe }\end{array}$ & $\begin{array}{l}\text { América } \\
\text { do Norte }\end{array}$ & $\begin{array}{l}\text { América } \\
\text { do Sul }\end{array}$ & $\begin{array}{l}\text { Ásia e } \\
\text { Oceania }\end{array}$ & Europa & $\begin{array}{l}\text { Oriente } \\
\text { Médio }\end{array}$ \\
\hline 2003 & $13,64 \%$ & $8,44 \%$ & $9,09 \%$ & $23,38 \%$ & $12,99 \%$ & $25,97 \%$ & $6,49 \%$ \\
\hline 2010 & $17,21 \%$ & $10,23 \%$ & $8,84 \%$ & $19,97 \%$ & $13,95 \%$ & $23,72 \%$ & $6,98 \%$ \\
\hline
\end{tabular}

Fonte: Elaboração a partir de Farias e Carmo ${ }^{245}$.

\footnotetext{
${ }^{244}$ Portaria MRE de 29 de julho de 2003 e Portaria MRE n. 534 de 31 de agosto de 2010.

${ }^{245}$ Rogério Farias e Géssica Carmo. Do Circuito Elizabeth Arden ao Circuito Global? A política de postos e remoções do Itamaraty. In: Mundorama - Revista de Divulgação Científica em Relações Internacionais, [acessado em 16/06/2015]. Disponível em: <http://www.mundorama.net/2015/06/16/do-circuito-elizabetharden-ao-circuito-global-a-politica-de-postos-e-remocoes-do-itamaraty-por-rogerio-de-souza-farias-e-gessicacarmo/>.
} 
A lotação de cargos nessas novas embaixadas foi estimuladas com a criação, em 2007, da classificação D, como parte do quadro criado em 1998. Essa classificação foi criada para regular as remoções, limitando o período em cada categoria. As categorias C e D possuem benefícios a fim de compensação pelo nível de vida do país e distância do Brasil, por exemplo. No caso da África, a maioria dos postos estavam classificados como D em 2010, e também concentra a maioria dos postos $\mathrm{D}$ no mundo, como podemos ver no mapa abaixo. Apenas África do Sul e os países da África setentrional receberam classificação C. Havia, e ainda há, um estímulo a remoções para o continente, que ainda não possui o máximo de ocupação em relação aos postos abertos ${ }^{246}$.

\section{Mapa 4 - Distribuição da classificação de postos no exterior em 2010}

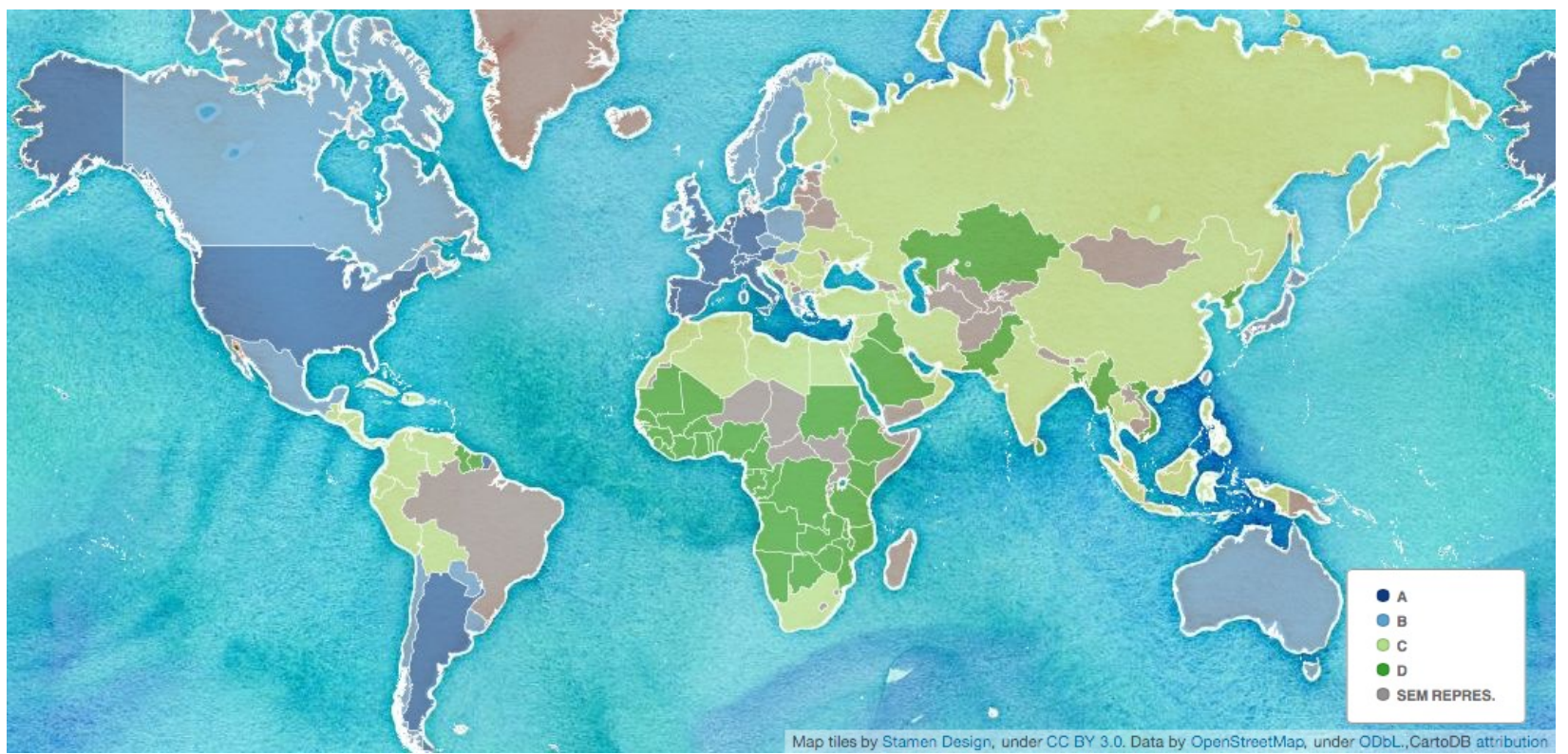

Fonte: Elaboração própria a partir da Portaria MRE n. 534 de 31 de agosto de 2010.

Considerando ainda o ano de 2010, os países africanos com o maior número de postos e diplomatas brasileiros são África do Sul (classificação C), com 11 (contando a embaixada e o Consulado Geral); Angola (classificação D), com 7; e Moçambique (classificação D), também com 7. Países como Egito, Tunísia, Argélia e Marrocos recebem 4 diplomatas cada. As embaixadas mais recentes têm, em sua maioria o mínimo possível de diplomatas lotados, conforme informação citada acima.

Nesse momento, podemos observar que a iniciativa de abertura de representações brasileiras em solo africano, por mais que não se possa medir exatamente o aumento da

246 FARIAS, Rogério e CARMO, Géssica, op. cit. [acessado em 16/06/2015]. Disponível em: $<$ http://www.mundorama.net/2015/06/16/do-circuito-elizabeth-arden-ao-circuito-global-a-politica-de-postos-eremocoes-do-itamaraty-por-rogerio-de-souza-farias-e-gessica-carmo/> 
estrutura funcional das mesmas, é condizente tanto com a nova política externa de Lula, que busca aproximar as relações do chamado Sul Global, quanto a própria linha do MRE, presente não apenas nesse período em tela, mas ao longo do tempo, de expandir a presença brasileira no mundo. Por uma outra perspectiva, o grande número relativo de embaixadas na África, Caribe e América Central ocorre mais pelo preenchimento de espaços vazios do que uma orientação "terceiro-mundista" ou "partidarizada", descaracterizando a política externa como uma política de Estado, como apontam críticos $^{247}$. Entretanto, o aumento dessas relações não ocorreu em detrimento de parceiros "tradicionais", como Estados Unidos e Europa. Essa iniciativa deve ser vista no conjunto das ações do período, de modo a verificar a coerência e vinculação com outras dimensões, como faremos nas seções seguintes.

\subsubsection{Síntese}

A partir do que foi analisado, a dimensão política da política externa para a África do governo Lula mostrou intensidade maior do que os períodos anteriores, tanto no aspecto multilateral quanto no bilateral. Em que pese a esfera multilateral ocorrer num âmbito mais geral, as relações Brasil-África estão presentes, seja na presença do Brasil e África do Sul nos agrupamentos BRICS e IBAS, por exemplo, seja em agrupamentos regionais, como CPLP e a Cúpula América do Sul-África. A esfera multilateral se relaciona com a bilateral no sentido de o Brasil fortalecer o discurso da mudança da ordem global, buscando maior participação do chamado Sul Global nos diversos fóruns internacionais.

A esfera bilateral, considerando as visitas de Estado e as aberturas de embaixadas, recebeu grande destaque no governo Lula, algo que é utilizado pelo discurso oficial e pelos críticos, como veremos no capítulo 3. As visitas ocorreram em todos os anos dos dois mandatos de Lula, com grande reciprocidade de chefes de Estado e de governo africanos. A chamada diplomacia de visitas, portanto, foi bem utilizada pelo presidente Lula, e fortaleceu laços políticos, o que pode ser visto tanto nas eleições da FAO e OMC quanto em manifestações de apoio recentes, de chefes de Estado africanos ao presidente Lula, no contexto das investigações de corrupção da Polícia Federal, que visam o ex-presidente.

Quanto à abertura de embaixadas, por um lado, foi um instrumento para fortalecer as relações bilaterais, consolidando também um canal de comunicação, o que ajudou no aumento da cooperação técnica; por outro lado, apesar do discurso oficial, não parece que houve um

\footnotetext{
${ }^{247}$ JAKOBSEN, Kjeld Aagaard. Desventuras de alguns críticos da política externa do governo Lula. In: Lua Nova, n. 89, São Paulo, 2013, p. 276-277.
} 
investimento no aumento do corpo diplomático e na infraestrutura dos novos postos, apesar do aumento de vagas gerado com os novos postos.

\subsection{Dimensão Cooperativa}

Esse tópico tem por objetivo analisar os dados pesquisados sobre a cooperação brasileira com países africanos no período em tela. Nesse sentido, foram pesquisados e analisados os projetos de cooperação que o Brasil desenvolveu no continente africano por meio da base de dados disponível no site da Agência Brasileira de Cooperação $(\mathrm{ABC})^{248}$, além de relatórios e publicações sobre o assunto, produzidos tanto pela $\mathrm{ABC}$ quanto pelo Instituto de Pesquisa Econômica Aplicada (IPEA). Foram empreendidas entrevistas com agentes brasileiros das principais áreas de cooperação internacional, incluindo a $\mathrm{ABC}^{249}$. Com o conjunto desses dados, procuraremos analisar a importância dessa dimensão na política externa brasileira para a África.

Antes de adentrarmos os dados da cooperação do governo Lula, faz-se necessário um breve histórico da cooperação internacional, a fim de deixar nítido os diferentes conceitos que estão abarcados no termo "cooperação internacional".

\subsubsection{Definições e histórico da Cooperação Internacional Brasileira}

$\mathrm{Na}$ bibliografia utilizada nesse ponto específico, não foi incomum encontrar afirmações de que o campo da cooperação internacional carece de novas e aprofundadas pesquisas $^{250}$, de melhor definição e delimitação ${ }^{251}$ e de arcabouço teórico minimamente aceito $^{252}$. Os agentes da cooperação internacional são igualmente difíceis de se identificar, existindo atualmente diversas categorias, como países de renda média ou baixa, países intermediários, economias ou doadores emergentes, BRICS, G-20, sociedade civil, terceiro

\footnotetext{
${ }^{248}$ http://www.abc.gov.br/Projetos/pesquisa

${ }^{249}$ Realizamos entrevistas na ABC, com o gerente de Cooperação Sul-Sul Paulo Lima; na Embrapa com os coordenadores de cooperação técnica Paulo Nogueira e Adriana Bueno; no ministério da Saúde com o assessor técnico Isaac Vergne; no ministério da Educação com o Coordenador de África Filipe Girardi; e na CGFome com o ministro Milton Rondó.

${ }^{250}$ PINO, Bruno Ayllón. O Sistema Internacional de Cooperação ao Desenvolvimento e seu estudo nas Relações Internacionais: a evolução histórica e as dimensões teóricas. In: Revista de Economia e Relações Internacionais, v. 5 (8), 2006, p. 5.

${ }^{251}$ Leite, Iara Costa. Cooperação Sul-Sul: Conceito, História e Marcos Interpretativos. In: Observatório Político Sul-Americano. V. 7, n. 3, 2012, p. 1.

${ }^{252}$ MELLO E SOUZA, André. Repensando a cooperação internacional para o desenvolvimento. In: Repensando a cooperação internacional para o desenvolvimento. Brasília: IPEA, 2014, p. 12.
} 
setor, entre outros ${ }^{253}$. Para os propósitos desse tópico, cabe aqui diferenciar e contextualizar rapidamente os conceitos de Cooperação Internacional para o Desenvolvimento (CID), Ajuda Oficial ao Desenvolvimento (AOD) e Cooperação Sul-Sul (CSS).

Parte da dificuldade de definição de cooperação internacional ou para o desenvolvimento, além das poucas pesquisas no tema, deve-se ao fato de que é um conceito que evoluiu no tempo - daí a necessidade de contextualização. A grosso modo, a cooperação seria "um conjunto de intervenções de caráter internacional orientadas à troca de experiências e recursos entre países do Norte e do Sul para atingir metas comuns baseadas em critérios de solidariedade, equidade, eficácia, interesse mútuo, sustentabilidade e corresponsabilidade." O fím último seria o fim da pobreza, do desemprego e desigualdade social nos países do $\mathrm{Sul}^{254}$. Ainda, outro problema da cooperação internacional é a dificuldade de quantificar e valorar as iniciativas e projetos. Não existe um padrão de registro entre os diversos países que oferecem a cooperação, e boa parte da cooperação técnica, transferência de conhecimento e tecnologia, treinamento, entre outros, compõe-se de ativos intangíveis, de difícil mensuração ${ }^{255}$ - algo que é sempre apontado pelos agentes de cooperação brasileiros quando perguntados sobre os orçamentos dos projetos brasileiros.

Mais detalhadamente, conforme definições apresentadas por Pino, a CID seria um conjunto de ações de caráter internacional, executadas por atores públicos e privados, entre países com diferentes níveis de renda, para promover desenvolvimento econômico e social em países em vias de desenvolvimento. O objetivo máximo da CID seria a erradicação da pobreza e desigualdade social e a melhora dos indicadores de desenvolvimento político, social, econômico e cultural dos países do sul.

Já a AOD englobaria os fluxos econômicos de agencias oficiais, governos estatais e locais, por meio de agências e instituições multilaterais - portanto de origem pública -, em direção a países em desenvolvimento, com a finalidade de promover o desenvolvimento econômico e social desses países ${ }^{256}$. Já a CSS aparece tanto de modo mais vago quanto como uma modalidade de CID. Numa perspectiva mais genérica, a CSS envolve um largo conjunto de ações relativas às relações entre países em desenvolvimento, como coalizões em geral, negociações multilaterais, integração regional, assistências para o desenvolvimento, fluxo de comércio, investimento, entre outros ${ }^{257}$.

\footnotetext{
253 Idem, p. 11.

${ }^{254}$ Pino, op. cit., p. 9.

${ }^{255}$ Mello e Souza, op. cit., p. 14.

${ }^{256}$ Pino, op. cit., p. 7.

${ }^{257}$ Leite, op. cit., p. 1.
} 
Em larga medida, a diferença entre AOD e CID estaria na verticalidade; a primeira embasada no eixo Norte-Sul, numa relações desigual de desenvolvimento, e a segunda, baseada mais no eixo Sul-Sul, mas não necessariamente apenas nesse eixo. A AOD seria mais utilizada pelos países desenvolvidos, apoiada na ideia de assistência, ao passo que a CID, mais especificamente a CSS, estaria baseada na cooperação, no sentido de reciprocidade, benefícios comuns, horizontalidade e ausência de condicionalidades, sejam sociais, ambientais, governança ou direitos humanos ${ }^{258}$. A diferença entre elas existe também por um motivo prático: a AOD, forma mais tradicional de assistência, é definida pelo Comitê de Assistência ao Desenvolvimento (CAD) da Organização para Cooperação e Desenvolvimento Econômico (OCDE), do qual a maioria dos países emergentes não faz parte, e portanto, buscaram formas alternativas a esse modelo para implementar ajuda a outros países. A definição do CAD de assistência limita-se aos empréstimos concessionais e créditos, ao passo que a CID se baseia, principalmente, em cooperação técnica, missões de paz, bolsas de estudos, comércio e investimento, entre outros.

No caso da CSS, para o Conselho Econômico e Social das Nações Unidas (ECOSOC), o conceito é mais amplo e mais profundo do que a assistência tradicional, pois é sustentado por princípios de solidariedade e cooperação mútua. Dentro da CSS estaria incluído não apenas fluxos financeiros, como empréstimos ou doações, mas também cooperação nos termos de troca de experiências, de tecnologias e capacidades, acesso preferencial a mercados, apoio ao comércio e investimentos, no nível de governos e agências específicas ${ }^{259}$.

Historicamente, a cooperação ao desenvolvimento surge no contexto do pós-guerra, na estruturação da Guerra Fria, desenvolvendo-se com a descolonização dos anos 1960, e alterando-se nos anos 90. Ou seja, é resultado de um processo histórico, confundindo-se também com as próprias relações internacionais e o sistema internacional. Especificamente, o que Pino chama de Sistema Internacional de Cooperação ao Desenvolvimento (SICD), refletiu o sistema bipolar do pós-guerra e a ênfase no eixo Leste-Oeste, depois foi influenciado pela descolonização e a consequente mudança da discussão para o eixo NorteSul, e, em seguida, reflete o processo de globalização e integração econômica mundial ${ }^{260}$. Nos anos 2000, passa a ocorrer um momento de dinamização e aprofundamento da cooperação entre os países em desenvolvimento.

A CSS, no entanto, não é recente. Pode ser datada da década de 1950, com iniciativas

\footnotetext{
${ }^{258}$ Mello e Souza, op. cit., p. 12.

${ }^{259}$ ECOSOC. Support to UN Development Cooperation Forum 2010: South-South and triangular cooperation: improving information and data. Nova Iorque: ECOSOC, 2009, p. iii.

${ }^{260}$ Pino, op. cit., p. 11.
} 
entre países asiáticos, como Tailândia, Coreia do Sul, Cingapura e Índia. No contexto do pósguerra, com o aumento de tensões políticas no eixo Leste-Oeste e com o início da descolonização, começa a surgir a identidade do "Sul". Países do "terceiro mundo" passam a dialogar, como Índia e China, de onde surgem os princípios da coexistência pacífica, em 1954, que levariam, no ano seguinte, para a Conferência de Bandung, e posteriormente para o Movimento dos Não Alinhados, em 1961. As relações Sul-Sul, nesse momento, passam a ser entendidas como instrumento e objetivo comum, o diálogo político e articulação, para aumentar o poder de barganha em fóruns internacionais e buscar a redução de desigualdades do sistema econômico mundial ${ }^{261}$.

A ênfase das discussões entre os países do Sul, inicialmente, caiu sobre as assimetrias do comércio mundial. Disso resulta a institucionalização da Conferência das Nações Unidas para Comércio e Desenvolvimento (UNCTAD), em 1964, que auxiliaria esses países a formular política comerciais e trocar experiências. Dentro da UNCTAD, resultado dessa troca, surge o G-77, grupo composto de 77 países em desenvolvimento, que demandavam novos marcos para o comércio internacional, intensificando as articulações, como contraponto econômico do Movimento dos Não Alinhados ${ }^{262}$.

Na década de 1970, o sistema de cooperação, conforme Pino sugere, cresce em abrangência, ao menos retórica. Não se demandava apenas reformas ou melhorias, como os desenvolvidos ofereciam, mas novas estruturas, em direção a um sistema mais justo. Em 1972, cria-se o grupo de trabalho sobre Cooperação Técnica entre Países em Desenvolvimento (CTPD), e em seguida a unidade especial de CTPD sob a chancela do Programa das Nações Unidas para o Desenvolvimento (PNUD). Ambas iniciativas culminariam na Conferência da ONU sobre CTPD, em 1978, em Buenos Aires, e com o Plano de Ação de Buenos Aires, para a promoção e realização da CTPD, estabelecendo os princípios orientadores da CSS. Nesse momento, surge o conceito de horizontalidade e intercâmbio de conhecimentos em diversas áreas, principalmente saúde, educação e agricultura, e o caráter multidimensional da cooperação, que poderia ocorrer sob diversas formas $^{263}$.

Nas décadas seguintes, em 80 e 90, refletindo o contexto de instabilidade econômica e financeira e o fim da Guerra Fria, a unidade dos países em torno da CSS foi desmobilizada. A crise energética, o choque do petróleo e a crise econômica forçaram uma introspecção nos

${ }^{261}$ PINO, Bruno Ayllón. Evolução Histórica da Cooperação Sul-Sul. In: Repensando a Cooperação Internacional para o Desenvolvimento. Brasília: IPEA, 2014, p. 60.

262 Pino, 2014, p. 63.

${ }^{263}$ Idem, p. 65. 
países em desenvolvimento, que se concentraram em assuntos internos para ajustes estruturais. Além disso, a onda neoliberal também teve por objetivo a deslegitimação das demandas do $\mathrm{Sul}^{264}$.

Apenas a partir de meados da década de 90, com a orientação da ONU, que a CSS entra em nova fase. Por meio de um documento intitulado Novas Orientações da CTPD, a ONU identifica um grupo de países - o Brasil incluído - que poderiam ser protagonistas no crescimento econômico regional e alavancar a cooperação entre os países em desenvolvimento. Também nesse momento, afirma Pino, o componente político da CSS vai perdendo espaço para as dimensões econômicas e técnicas - também refletindo novas condições e capacidades técnicas, além de avanços institucionais. Assim, o componente ideológico, característico do início do processo, não era mais o principal elemento de expansão da $\operatorname{CSS}^{265}$.

A fase mais recente tem início no século XXI, em 2000, com a I Cúpula do Sul, em Havana, onde se reafirma que a CSS é o instrumento eficaz para o desenvolvimento dos países do Sul, a fim de reduzir as assimetrias e desigualdades nas relações econômicas internacionais. Ao mesmo tempo, países em desenvolvimento tidos como "de renda média" começam a mudar de situação, de receptores a doadores de assistência, saindo também do âmbito da $\mathrm{AOD}$ e dos critérios do CAD da OCDE, que passam a chamar os novos atores de “doadores emergentes", “doadores não tradicionais”, epítetos que esses países não aceitam ${ }^{266}$.

No contexto do surgimento da cooperação internacional, no pós-guerra, o Brasil se situava como um receptor de cooperação e assistência. O primeiro marco institucional é a criação da Comissão Nacional de Assistência Técnica (CNAT), em 1950, com o intuito de sistematizar a recepção de assistência técnica. Essa comissão era composta por membros da secretaria de planejamento, do MRE e ministérios. O foco das primeiras décadas de cooperação foi no fortalecimento de instituições públicas e entidades especializadas consideradas estratégicas, que resultariam na Empresa Brasileira de Pesquisa Agropecuária (Embrapa), Instituto Nacional de Propriedade Industrial (INPI), Serviço Nacional de Aprendizagem (Senai), entre outros ${ }^{267}$.

Com o aumento do volume de cooperação, foi feita uma reforma no sistema de cooperação técnica brasileiro, que apresentava limitações estruturais. Assim, as competências

\footnotetext{
${ }^{264}$ Idem, p. 67.

${ }^{265}$ Idem, p. 71.

${ }^{266}$ Idem, p. 72-77.

${ }^{267}$ Abreu, Fernando José Marroni de. A evolução da Cooperação Técnica no Brasil. In: Mural Internacional, v. 4, n. 2, 2013, p. 4
} 
básicas de coordenação, negociação, execução, acompanhamento, foram centralizadas na Subsecretaria de Cooperação Econômica e Técnica Internacional (Subin) da Secretaria de Planejamento da Presidência da República (Seplan) e na Divisão de Cooperação Técnica do MRE, ao final da década de $1960^{268}$. Esse novo sistema refletiu na criação e consequente aumento de cooperação técnica brasileira para países em desenvolvimento e com realidades semelhantes, dentro do contexto da própria evolução do sistema internacional de cooperação na década de 70, como vimos acima. A partir de então, o Brasil começa a ser também um doador de cooperação, não apenas receptor. Os relatórios de gestão do MRE, publicados em alguns anos, passam a refletir esse crescimento, apontando cooperação com países africanos, principalmente lusófonos, países asiáticos e latino americanos ${ }^{269}$.

Na década de 1980, com o aumento da cooperação oferecida, o governo brasileiro reformula o sistema, extinguindo a Subin em março de 1987, passando as atividades e competências totalmente para a esfera do MRE, com a criação, em dezembro de 1987, da Agência Brasileira de Cooperação (ABC), inaugurada pelo então presidente Sarney $^{270}$. A ênfase da atuação recairia nos países africanos lusófonos e países vizinhos sul-americanos. Naquele momento, a ABC estaria ligada à Fundação Alexandre de Gusmão, vinculado ao MRE. O primeiro diretor da agência foi o diplomata Luiz Felipe Lampreia, que seria mais tarde chanceler do governo Fernando Henrique. Segundo Marroni, a inovação trazida pela $\mathrm{ABC}$ consistia em unificar as funções técnicas à pauta da política externa brasileira ${ }^{271}$.

Para Marroni, também diplomata de carreira e diretor da ABC no primeiro mandato de Dilma Rousseff, a cooperação técnica brasileira consolidou-se como relevante instrumento de correção de assimetrias sociais e econômicas, em consonância com a nova fase da CSS, baseada em solidariedade e horizontalidade. A cooperação brasileira baseia-se na "diplomacia solidária", sem fins lucrativos e interesses econômicos, com o objetivo de colaborar com o progresso econômico e social de outras nações. A cooperação técnica se baseia no planejamento conjunto com o país parceiro, preservando a soberania e o princípio de não ingerência ${ }^{272}$.

Em relação ao orçamento, como já mencionado, tanto a CSS quanto a cooperação brasileira não seguem as regras da AOD referente à mensuração e registro de gastos. Apenas recentemente, a partir de 2010, houve esforço tanto da ABC quanto do IPEA no sentido de

\footnotetext{
${ }^{268}$ Idem, p. 4.

${ }^{269}$ Brasil, MRE. Relatório. Brasília: MRE, 1973, 1974, 1975 e 1978.

${ }^{270}$ Idem, Relatório 1987, p. 125.

${ }^{271}$ Abreu, op. cit., p. 5.

${ }^{272}$ Idem, p. 6.
} 
elaborar relatórios sobre as origens e destinos dos orçamentos da cooperação brasileira, que se traduziram em 2 relatórios chamados "Cooperação Brasileira para o Desenvolvimento Internacional" (Cobradi), que cobrem o período de 2005-2009 e 2010. Entretanto, utilizam metodologias diferentes em cada relatório. Tanto Marroni quanto outros agentes brasileiros de cooperação afirmam que os custos da cooperação brasileira são reduzidos - relativamente a outros custos de cooperação internacional - pois as ações são em grande medida realizadas por técnicos especializados das instituições brasileiras, ou seja, não há gastos adicionais ao salários, que são contabilizados como "horas técnicas". Porém, ao mesmo tempo que reduzem contabilmente os gastos, dificultam a sua mensuração, sendo que, desse modo, a execução financeira da cooperação técnica brasileira é subestimada.

\subsubsection{A Cooperação brasileira para África no período Lula}

A cooperação brasileira no período proposto reflete a evolução história da CSS colocada acima. Mendonça coloca que, nesse aspecto, a política externa de Lula enfatiza a diversificação de parcerias dentro da lógica da busca de alternativas ao modelo vertical, sem deixar de incluir o conceito de "diplomacia solidária". Essa política externa, portanto, não seria simples cópia da PEI ou do Pragmatismo Responsável dos anos 1960 e $1970^{273}$. Em relação à África, de acordo com um conceito mais amplo de CSS, praticamente toda a política externa referente ao continente africano pode ser encaixada nesse conceito. Nesse subtópico, vamos analisar a cooperação internacional brasileira para a África, abrangendo a cooperação técnica e humanitária.

Conforme o relatório Cobradi de 2010, a cooperação brasileira é um instrumento importante da política externa brasileira, baseada em "princípios alinhados às visões de relações equânimes e de justiça social" ${ }^{274}$, livre de condicionalidades.

Vista em conjunto, a cooperação brasileira, seja abrangendo apenas a execução de projetos seja o dispêndio geral na cooperação para o desenvolvimento, teve aumento gradativo, chegando ao auge em 2010. A Cobradi como um todo teve um orçamento de centenas de milhões de reais ao longo de 2005 a 2010, período abrangido pelos relatórios, saindo de cerca de $\mathrm{R} \$ 380$ milhões para $\mathrm{R} \$ 1,6$ bilhão em 2010. Esses valores são relativamente altos pois a metodologia utilizada inclui as contribuições a organizações

\footnotetext{
${ }^{273}$ MENDONÇA JÚNIOR, Wilson. Política Externa e Cooperação Técnica: As relações do Brasil com a África durante os anos FHC e Lula. Belo Horizonte: D'Plácido Editora, 2013, pos. kindle 1560.

${ }^{274}$ IPEA. Cooperação Brasileira para o desenvolvimento internacional. Brasília: IPEA, ABC, 2010, p. 16.
} 
internacionais e operações de manutenção de paz, que no período correspondem a mais de dois terços do total. $\mathrm{O}$ orçamento da $\mathrm{ABC}$ para a execução dos projetos que organiza, no entanto, se refere a uma pequena parte disso, chegando ao máximo de R\$60 milhões em 2010, e cerca de $10 \%$, em média, do total dispendido em cooperação técnica por todos os órgãos brasileiros, como podemos ver no gráfico abaixo.

Gráfico 2 - Orçamento da ABC e total da Cobradi em Cooperação técnica (em U\$)

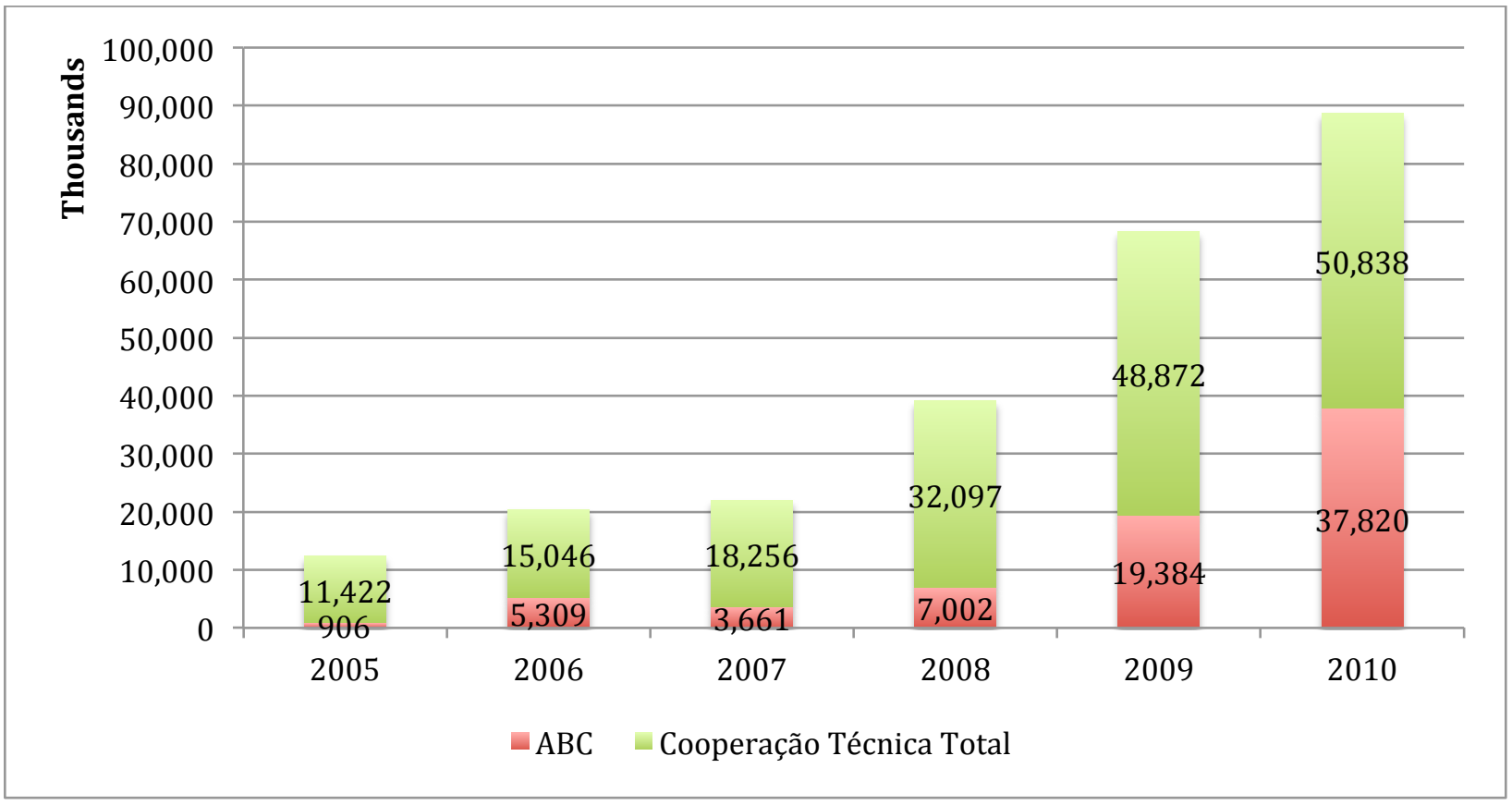

Fonte: elaboração própria, a partir de IPEA, 2010 e www.abc.gov.br

Os países africanos foram responsáveis pela maior parte do orçamento para execução de projetos da $\mathrm{ABC}$, seguindo o mesmo padrão de crescimento do orçamento total da agência. Mas apenas nos anos finais do mandato de Lula que o montante cresce significativamente, para após apresentar uma queda paulatina no primeiro mandato de Dilma Rousseff, como podemos ver no gráfico abaixo. O montante destinado à África, no governo Dilma, mantémse relativamente alto em relação ao orçamento da $\mathrm{ABC}$, apesar da evidente queda orçamentária. 
Gráfico 3 - Comparação dos orçamentos para África e total em execução de projetos (US\$)

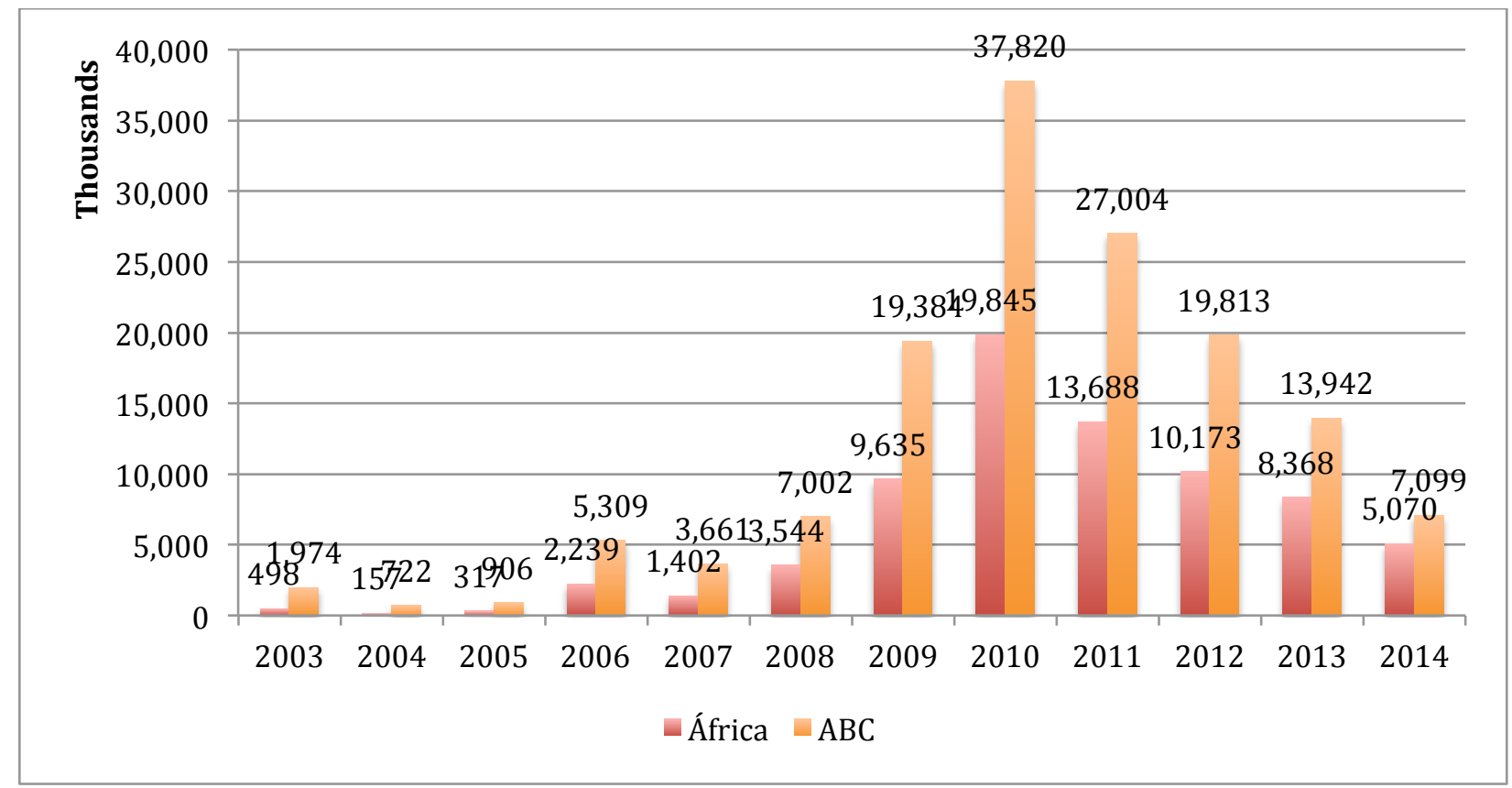

Fonte: elaboração própria, a partir de www.abc.gov.br

A seguir, analisaremos os dados pesquisados sobre os projetos de cooperação para a África no âmbito da ABC. Para tanto, utilizamos a ferramenta de pesquisa presente na página web da $\mathrm{ABC}$, uma vez que nos relatórios Cobradi não existe um detalhamento específico sobre os projetos, como os países recipientes, anos e setores. Não existem informações sobre o orçamento executado em cada projeto. No entanto, os dados levantados são suficientes para identificar a expansão ou concentração de projetos em países ou setores.

Cabe mencionar o estudo de Wilson Mendonça Júnior sobre os acordos bilaterais de cooperação, que são os instrumentos diplomáticos que estabelecem os arcabouços jurídicos nos quais estão inseridos os projetos de cooperação. Quatro foram os tipos de acordos bilaterais levantados: Acordo Geral - um acordo abrangente; Protocolo de Intenções acordos complementares ou interpretativos de acordos anteriores; Memorandos de Entendimento - atos simplificados que registram princípios gerais; e Ajuste Complementar instrumento jurídico para executar um outro ato concluído ou em vigor ${ }^{275}$. Os dados foram pesquisados na página web do Departamento de Atos Internacionais (DAI) do MRE. Desse modo, o autor pôde fazer um comparativo entre o governo Fernando Henrique e Lula quanto ao número de acordos e abrangência de parceiros. No governo Fernando Henrique, 33 acordos bilaterais foram firmados, com 11 países africanos. Houve uma concentração de acordos na África meridional e PALOPs, com a exceção da Tunísia e Nigéria. Destaca-se que

\footnotetext{
${ }^{275}$ Mendonça Júnior, op. cit., ref. Kindle 2064.
} 
a maioria dos acordos gerais, celebrados com Cabo Verde, Angola, Nigéria e Moçambique são da época da ditadura. Há uma concentração de acordos nos setores de educação, cultura e formação profissional ${ }^{276}$.

No governo Lula, os acordos, assim como os projetos, se concentram temporalmente de meados para o fim de seu período. $\mathrm{O}$ orçamento da $\mathrm{ABC}$ ganha aporte orçamentário a partir de 2005, assim como 77 novos funcionários concursados ${ }^{277}$. Durante esse período, houve um aumento significativo de acordos bilaterais de cooperação técnica, num total de 238, com concentração de setores em saúde (44 acordos), agricultura (29), educação (22) e formação profissional (22). Foram firmados 10 novos Acordos Gerais, expandido as relações bilaterais, para 35 países africanos parceiros ${ }^{278}$, número próximo ao de embaixadas brasileiras no continente africano ao fim do período. Geograficamente, os acordos do período Lula se expandiram ainda mais na África meridional e ocidental, expandindo também para a África oriental e do norte.

Quanto aos projetos especificamente, como dito, foi feito um levantamento pelo instrumento de pesquisa da página web da $\mathrm{ABC}^{279}$, buscando os dados referentes aos itens “cooperação Sul-Sul” e área geográfica "África”, passando a selecionar, manualmente, os projetos por ano, uma vez que não há essa opção. Duas dificuldades ocorreram: muitos resultados de pesquisa não apresentavam o país recipientes; e os códigos dos projetos não constavam com explicação. Na entrevista feita com Paulo Lima, coordenador da Gerência de África de língua portuguesa da $\mathrm{ABC}$, pudemos dirimir essas dúvidas e refazer a pesquisa por país e setor determinado e não pela área geográfica geral, o que significou completar praticamente $100 \%$ dos 460 projetos pesquisados.

Além disso, os códigos dos projetos, por exemplo BRA/98/004-A010 ou BRA/04/044-S002, referem-se a dois tipos de projetos, quais sejam, de ação preparatória (S) ou de ação simplificada (A). Para a ABC, todo projeto é uma ação planejada, com prazo definido, composto de várias atividades inter-relacionadas, e é por meio deles que a cooperação prevista nos Ajustes Complementares e Memorandos de Entendimento é implementada. Os projetos preparatórios tem duração maior, a fim de desenvolver a estrutura de uma determinada cooperação, com identificação e prospecção conjunta das demandas, e oferecer a estrutura para estudos de viabilidade, geralmente resultando em projetos ou

\footnotetext{
${ }^{276}$ Idem, op. cit., ref. Kindle 2335.

${ }^{277}$ Idem, op. cit., ref. Kindle 2382.

${ }^{278}$ Idem, op. cit, ref. Kindle 3134.

${ }^{279}$ Página web da ABC. Disponível em http://www.abc.gov.br/Projetos/pesquisa, acesso em 15 de junho de 2016
} 
programas. As ações simplificadas são atividades pontuais e de prazo curto, como consultoria, participação em eventos, intercâmbios e treinamentos, e não resultam em etapas subsequentes $^{280}$. Compreensivelmente, a maioria dos projetos pesquisados são de ações simplificadas.

Gráfico 4 - Distribuição de Projetos de cooperação por países 2003-2010

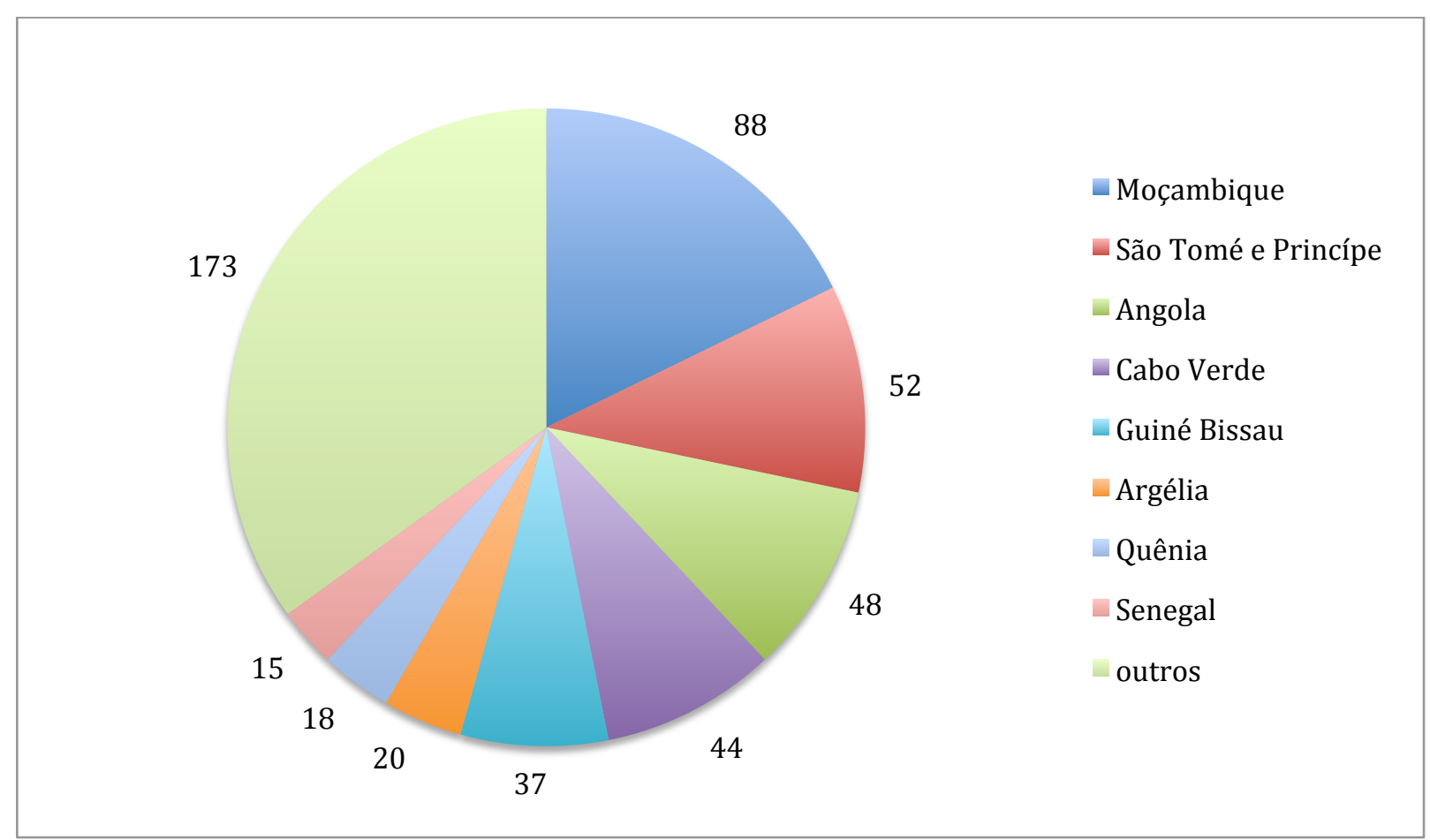

Fonte: elaboração própria a partir de www.abc.gov.br/Projetos/pesquisa

O gráfico acima mostra a concentração de projetos, considerando ambas modalidades, nos países africanos de língua portuguesa, que concentram sozinhos 269 projetos, o equivalente a $54 \%$ do total de projetos. Por outro lado, 40 países africanos contam com algum projeto de cooperação brasileira, uma diferença perceptível em relação ao período anterior, quando apenas 11 países poderiam ser contemplados. No mapa a seguir, podemos observar a disposição geográfica dos projetos no continente africano, com uma escala de intensidade. Apesar da distribuição geográfica maior do que em períodos anteriores, a concentração nos PALOPs e na África ocidental fica evidente na representação cartográfica. A cooperação brasileira passa a cobrir boa parte do continente africano, mas a concentração aumenta desproporcionalmente.

\footnotetext{
${ }^{280}$ Brasil. MRE. ABC. Manual de Gestão de Cooperação Técnica Sul-Sul. Brasília: MRE, 2013, p. 19-20.
} 
Mapa 5 - Intensidade dos projetos de cooperação por país

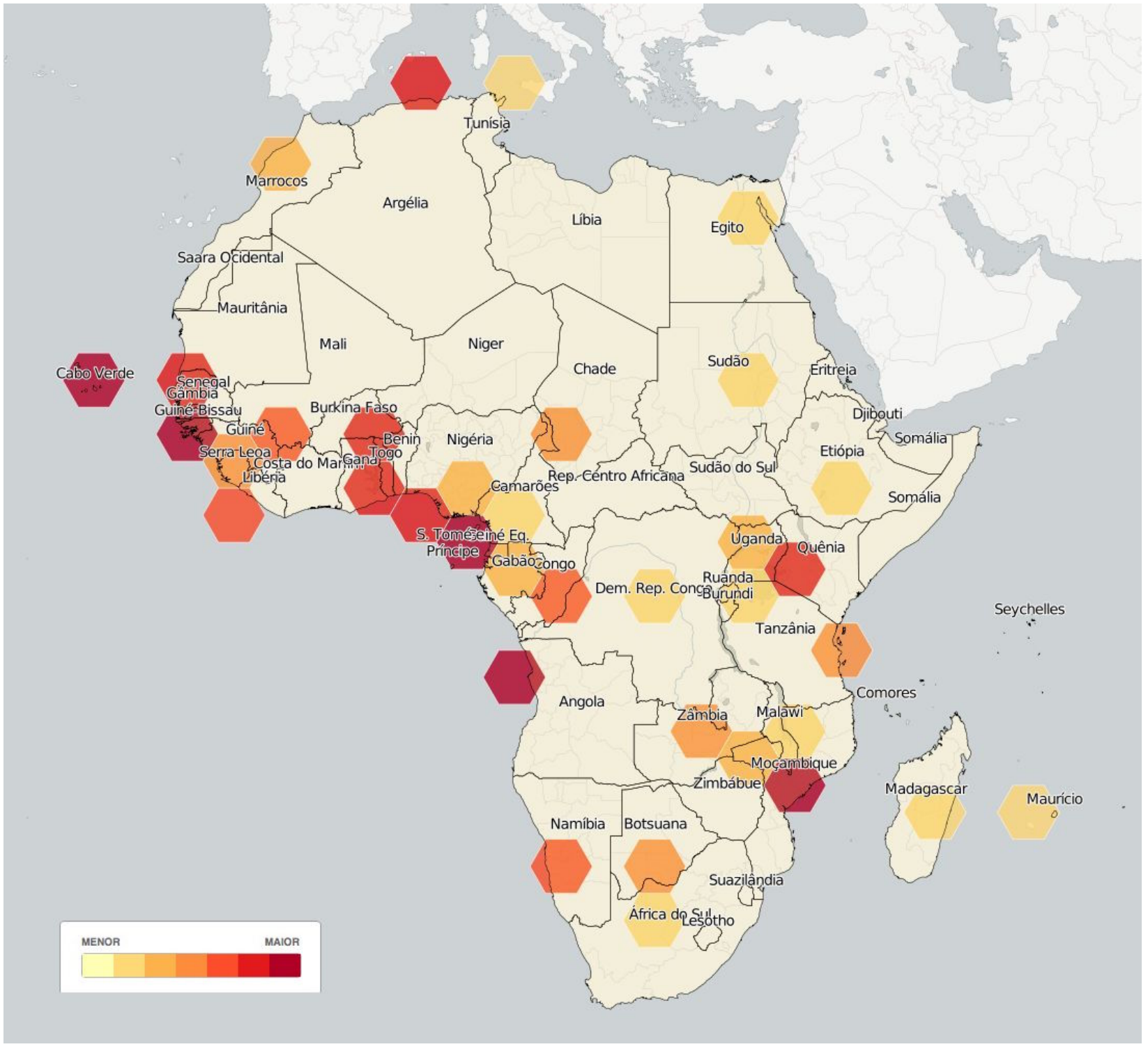

Fonte: elaboração própria a partir de www.abc.gov.br/Projetos/pesquisa

No gráfico abaixo, podemos ver a relação do número de projetos com o aumento do orçamento para execução de projetos para a África da ABC. O número de projetos é crescente no período, refletindo tanto a celebração de novos acordos gerais quanto o aumento de orçamento e pessoal da $\mathrm{ABC}$. $\mathrm{O}$ número de projetos é crescente, mas o orçamento destinado à África cresce realmente apenas em 2009 e 2010, tendo um aumento do valor médio dos projetos no final desse período. 
Gráfico 5 - Número de projetos em relação ao orçamento da $\mathrm{ABC}$, para África (U\$)

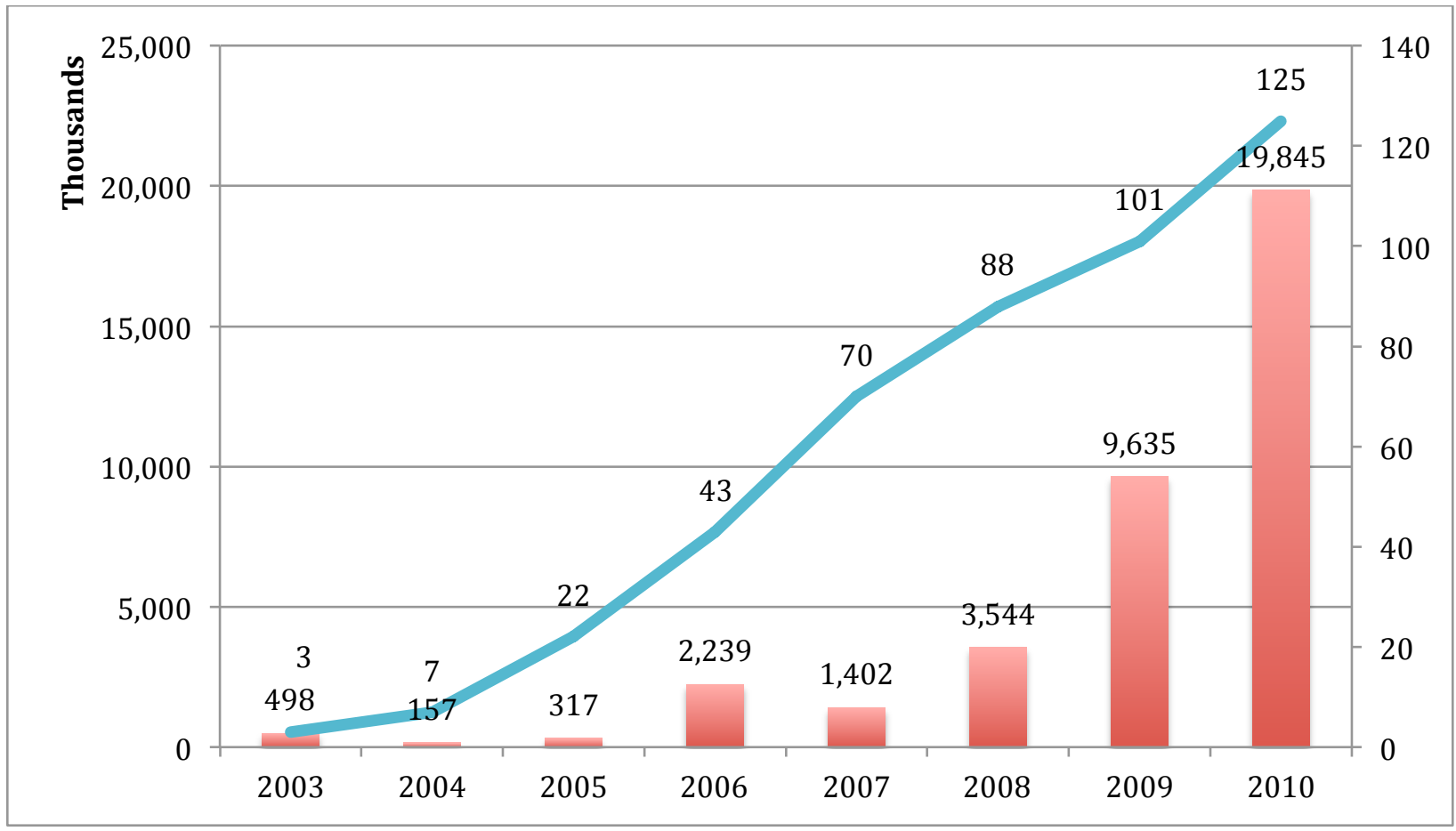

Fonte: elaboração própria a partir de www.abc.gov.br/Projetos/pesquisa

Como observado acima, os Acordos bilaterais de cooperação técnica se concentraram nas áreas de Saúde, Agricultura e Educação, o que se refletiu também com os projetos, porém mais de 20 setores são classificados para os projetos, além de sub-áreas. Outros setores de destaque são Meio Ambiente, Administração Pública, Cidades, Desenvolvimento social, Planejamento, Cultura, Esporte e Indústria e Comércio. O gráfico abaixo apresenta os principais setores abarcados pelos projetos.

Gráfico 6 - Distribuição de Projetos por principais setores no governo Lula

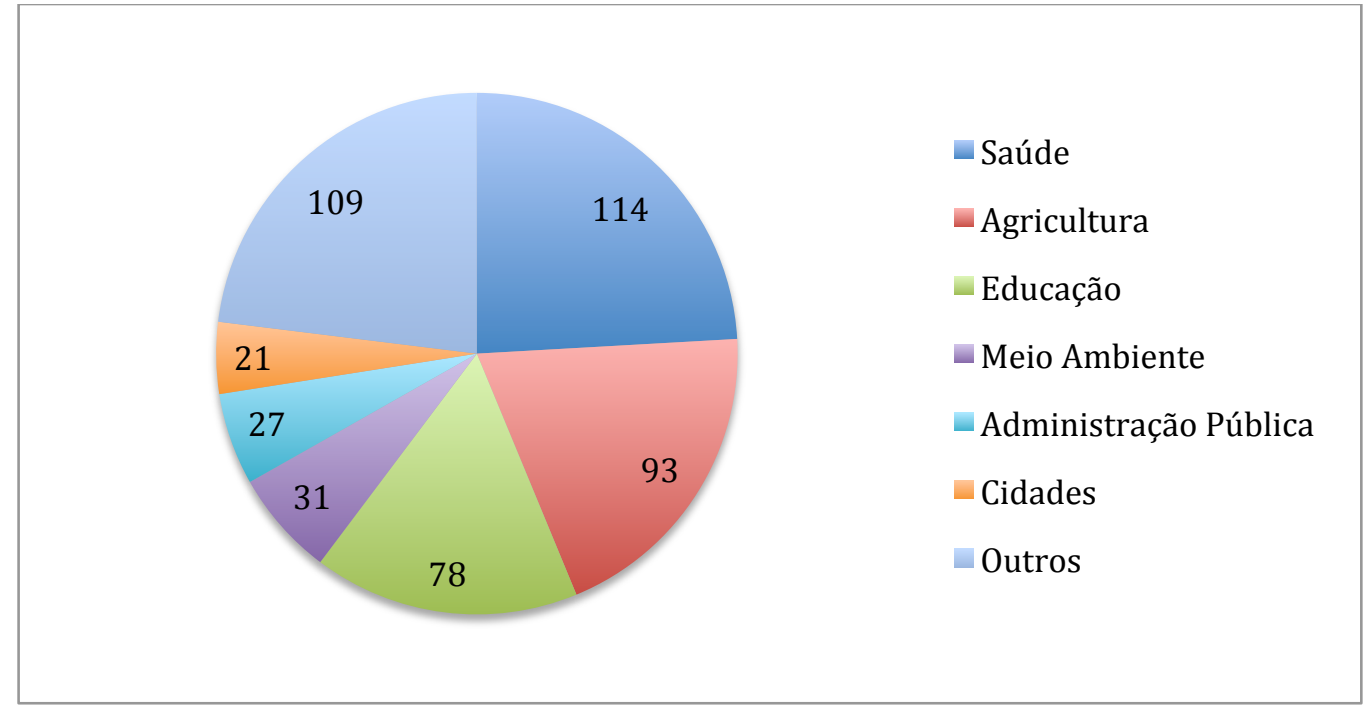

Fonte: elaboração própria a partir de www.abc.gov.br/Projetos/pesquisa 
O maior número de projetos em Saúde reflete tanto a consolidação do Brasil como importante ator no campo internacional, que vem ocorrendo desde 2003, quanto a crescente demanda dos países africanos, que são os que mais sofrem com casos de epidemia e doenças no mundo, como cólera, diarreia infantil, malária, AIDS e outros.

Conforme entrevista realizada com o assessor técnico Isaac Vergne, da Assessoria de Assuntos Internacionais de Saúde, do Ministério da Saúde (MS), em conjunto com o MRE e ABC construíram forte relação, principalmente no período do governo Lula - apesar de o MS fornecer cooperação técnica desde a década de 60 , permitindo um aumento expressivo do intercâmbio de experiências com os países africanos. Vários projetos de médio e longo prazo, chamados de estruturantes pela $\mathrm{ABC}$, pois visam a construção e estruturação de instituições para formação de profissionais capacitados, deixando um legado a longo prazo, permitem o fortalecimento das relações. Ao longo da execução dos projetos, os técnicos brasileiros vão aos países receptores da cooperação, trabalhando junto com técnicos africanos e, ao longo do tempo podem ver os resultados, como Isaac relata ao verificar que, em uma das viagens que fez à África, técnicos e profissionais de saúde utilizavam tanto as fichas quanto a metodologia de classificação ensinadas pelos técnicos brasileiros anos antes ${ }^{281}$.

Por sub-área temática, pode-se verificar as maiores demandas africanas. Ocorreram 9 projetos relacionados a HIV/AIDS, seguido por 8 projetos de prevenção à Malária, e 3 contra doença falciforme. Há projetos para o apoio à prevenção da tuberculose, como também de estruturação do sistema de saúde, construção de banco de leite e saúde bucal ${ }^{282}$.

A segunda área com maior número de projeto é a de agricultura. A cooperação brasileira nessa área se beneficiou da expertise da Embrapa em agricultura tropical, adquirida desde a década de 1970. Além disso, pela semelhança da região tropical e características agroecológicas similares entre as duas regiões, a demanda de projetos na área foi crescente no período. Mais de 50 acordos bilaterais foram assinados durante o governo Lula na área, com 18 países africanos. A Embrapa oferece capacitação e realização de ações conjuntas na África, incluindo transferência de tecnologias, permitindo o compartilhamento de experiências na agropecuária, agroflorestal e meio ambiente. Em 2007, foi assinado acordo para a instalação de Escritório Regional para a África, que foi instalado em 2008, em Acra, Gana. Outros ministérios participam de projetos na área, ao lado da Embrapa, como o

\footnotetext{
${ }^{281}$ Vergne, Isaac. Entrevista ao autor. Brasília, 07 de abril de 2016.

${ }^{282}$ Vergne, Isaac. O financiamento da cooperação técnica em saúde pela ABC: tendências no periodo 20032013. Brasília: Fiocruz. Dissertação, 2014, p. 51.
} 
Ministério do Desenvolvimento Agrário (MDA) e Ministério de Agricultura, Pecuária e Abastecimento (MAPA). Nessa área, houve alto grau de prioridade em relação aos países $\operatorname{africanos}^{283}$.

O projeto mais bem-sucedido nessa área é o chamado Cotton-4, na temática do algodão. Após o êxito brasileiro no chamado contencioso do algodão no âmbito da Organização Mundial do Comércio (OMC), a CSS na área trouxe ações coordenadas contra subsídios agrícolas no mercado internacional. Com a demanda dos países do Cotton-4, Benim, Burkina Faso, Mali e Chade, elaborou-se o Projeto Cotton-4, com início em 2009. Esse projeto se concentrou no fortalecimento de capacidades locais, na formação de recursos humanos e compartilhamento de experiências, e transferência de tecnologias brasileiras, cujos pilares são o melhoramento genético da planta, o desenvolvimento do manejo integrado de pragas, e introdução do sistema de plantio direto. A primeira fase do projeto durou até 2013, apresentando excelentes resultados, como a revitalização da cotonicultura no Mali, com infraestrutura laboratorial e administrativa, por meio da instalação de fazenda modelo para produção de algodão; introdução de dez variedades brasileiras de plantas; realização de 22 capacitações no Brasil e países africanos, e a elaboração de manual de boas práticas $\operatorname{agrícolas~}^{284}$.

Em entrevista com o coordenador de cooperação técnica da Secretaria de Relações Internacionais da Embrapa, Paulo Nogueira, e com Adriana Bueno, também da coordenadoria, foi possível colher informações sobre a cooperação brasileira na área. Em primeiro lugar, eles frisam que a Embrapa é uma executora de cooperação, atuando de acordo com as orientações do governo, por meio da $\mathrm{ABC}$, que são os formuladores das políticas de cooperação. Eles apontaram que o período Lula foi "um ponto fora da curva" em relação ao aumento da cooperação com a África. Segundo Paulo, ainda, o grande estímulo à expansão da cooperação no governo Lula aumentou demais a expectativa, que, olhando pra trás, talvez tenha sido exagerada.

A diplomacia presidencial de Lula foi fundamental, segundo eles, para o aumento de projetos com a África. Houve um "antes e um depois" em relação à Lula. Antes, havia maior treinamento de técnicos. A Embrapa não tem meios orçamentários para executar os projetos, além das horas técnicas dos seus funcionários, necessitando da intermediação da $\mathrm{ABC}$ e do PNUD, que normalmente é o canal para a transferência de montantes destinados aos projetos

\footnotetext{
${ }^{283}$ Brasil. MRE. Balanço da Política Externa 2003-2010, p. 175.

${ }^{284}$ Informações obtidas em entrevista na Embrapa. Nogueira, Paulo e Bueno, Adriana. Entrevista com o autor. Brasília, 5 de abril de 2016.
} 
na África. Por isso, apontam, essa relação funciona mal, necessitando a $\mathrm{ABC}$ de maior autonomia. Depois do período Lula, o contingenciamento orçamentário afetou sobremaneira os projetos em execução. O Cotton-4 funciona bem por conta do financiamento via o contencioso do algodão. Para fugir desse contingenciamento, a Embrapa busca parcerias de outras instituições internacionais para o financiamento e continuidade de projetos na África ${ }^{285}$.

Ainda em relação à Embrapa, frequentemente é mencionado a iniciativa do escritório da Embrapa em Gana. Em relação a esse tema, os coordenadores afirmaram que essa iniciativa é entendida equivocadamente como um "escritório", ou seja, um local onde a Embrapa executa e organiza projetos. Na realidade, foi uma iniciativa do MRE em conjunto com Gana, no qual a Embrapa utiliza um espaço cedido pela International Water Management Institute (WMI) desde 2006. A princípio, o objetivo desse projeto, como o chamam os coordenadores, era fazer a captação de outros projetos e tecer relações com outras instituições de pesquisa e universidades, dos países da região. Com o aumento expressivo das demandas, foi percebido que tal modelo não funcionaria, passando essa representação a funcionar como ponto de apoio dos projetos já existentes, enquanto as demandas por projetos ficaria concentrado com a ABC. O "escritório", portanto, ficaria como um "projeto de liaison" e como sede do projeto da Embrapa na África. No entanto, desde 2015, em consequência da contingência de custos, não há um coordenador da Embrapa em Gana, e muito provavelmente o uso do espaço não será renovado.

Uma outra participação importante da Embrapa na Cooperação Internacional, citada pelos coordenadores, é a Agricultural Innovation Marketplace: uma plataforma de inovação, composta por um comitê executivo formado por fundações e doadores internacionais, que selecionam projetos relacionados à agricultora em países da África, América Latina e do Caribe. A plataforma foi criada em 2010, e tanto a ABC quanto a Embrapa participam, aquela no comitê, esta no gerenciamento e acompanhamento dos projetos oferecidos. Segundo Paulo Nogueira, é uma forma da Embrapa continuar trabalhando com cooperação internacional apesar do contingenciamento orçamentário recente. A Embrapa, no caso, apenas participa cedendo horas técnicas de seus funcionários.

A terceira área com maior número de projetos é a de educação. Como no caso da agricultura, a cooperação internacional brasileira na área é bem anterior ao período estudado. $\mathrm{Na}$ África, há especial identificação com os PALOPs. O maior programa é de bolsas de

${ }^{285} \mathrm{Idem}$. 
estudos para alunos africanos, dentro dos quadros dos Programa de Estudantes-Convênio de Graduação (PEC-G) e Programa de Estudantes-Convênio de Pós-graduação (PEC-PG), sendo que o primeiro tem mais de 50 anos de existência. Durante o período Lula, houve o incremento de bolsas aos PALOPs, mas também a intensificação da busca de novos parceiros. A seleção dos alunos ocorre por exames realizados pelo MRE. Mais de 4 mil alunos africanos foram selecionados no período no PEC-G, e mais de 200 no PEC-PG, considerando ainda que não estão restritos ao continente africano. Em entrevista no Ministério da Educação com os coordenadores da Assessoria Internacional, além desses dados foi também mencionado os projetos de educação especial e apoio à alimentação escolar, dentro do âmbito de uma política educacional. Esses projetos tiveram sucesso e foram chamarizes para novas demandas de países africanos ao longo do período, principalmente por meio das novas embaixadas brasileiras na África ${ }^{286}$.

Por fim, outra vertente da cooperação brasileira é a cooperação humanitária, que começa a ganhar organização com a criação de um departamento especifico dentro do MRE, a Coordenação-Geral de Ações Internacionais de Combate à Fome (CGFome). Este foi criado para se o braço internacional do programa Fome Zero, coordenando a política externa brasileira nos temas de segurança alimentar e nutricional, desenvolvimento rural e cooperação humanitária. O diplomata Milton Rondó foi um dos responsáveis pela criação da coordenação, assim que o presidente Lula assumiu o governo ${ }^{287}$. A principal ação do CGFome em relação à África é a doação de alimentos.

Um indicativo do aumento da importância da cooperação e humanitária está no orçamento dedicado a elas dentro de toda a cooperação para o desenvolvimento internacional. Em 2005, dedicou-se a elas $\mathrm{R} \$ 28,9$ milhões $(7,53 \%$ do total), e em 2009 , $\mathrm{R} \$ 184,8$ milhões (25\%), e R\$385 milhões (24\%) em $2010^{288}$. Em 2010, R\$64 milhões foram direcionados à África. Esse mesmo montante foi direcionado aos países africanos em todo o período de 2005-2009.

Os dados específicos sobre as ações e projetos de cooperação humanitária e técnica não são abertamente disponíveis, apesar da possibilidade de pesquisa a partir das páginas da ABC e da CGFome: as informações disponíveis não são completas. No caso da assistência humanitária, somente a partir de 2008 que existem compilações e detalhamentos das iniciativas. No caso dos projetos da $\mathrm{ABC}$, é possível pesquisar por todos os anos e setores,

\footnotetext{
${ }^{286}$ Girardi, Filipe. Entrevista ao autor. Brasília, 08 de abril de 2016.

${ }^{287}$ Rossi, Amanda. Moçambique, o Brasil é aqui. Rio de Janeiro: Record, 2015, p. 182.

${ }^{288}$ IPEA, Cooperação Brasileira para o Desenvolvimento Internacional, 2005-2009 e 2010.
} 
mas detalhes dos projetos, como resultados, não são abertos.

No caso da assistência humanitária, no período de 2008 a 2010, foi possível verificar que 23 países africanos foram destinatários de assistência brasileira, em 3 rubricas: colaboração financeira, doação de alimentos e doação de medicamentos. Os principais destinatários foram países da CPLP, com 20 ações (Moçambique recebendo 8, Guiné-Bissau 4, São Tomé e Príncipe e Cabo Verde 3, Angola 2); Zâmbia, com 5; Togo, Sudão e Quênia 3; e África do Sul 2. No total, os dispêndios foram de US\$7.966.718,99, sendo que 97\% disso em colaborações financeiras, $2.6 \%$ em medicamentos e apenas $0.1 \%$ em alimentos ${ }^{289}$. No relatório COBRADI 2005-2009, não há um detalhamento como esse em relação à África, apenas apontando o total, de $\mathrm{R} \$ 10.269 .463,80$, que corresponde a 7,26\% do total, atrás de América Latina e Ásia. Não existe uma priorização de regiões a priori, pois a cooperação humanitária responde em boa parte a calamidades e desastres naturais.

Em entrevista com o diplomata Milton Rondó, foi enfatizado o Programa de Aquisição de Alimentos (PAA), que o CGFome articula e organiza. O programa compra diretamente parte da produção de agricultores familiares para distribuir gratuitamente a entidades sociais e grupos em situação de vulnerabilidade. Garante, ao mesmo tempo, renda e trabalho a grupos rurais e alimento para famílias pobres. O programa obteve êxitos, foi estendido a países africanos e latino-americanos, a partir de 2008, por meio de ONGs, principalmente. Perguntado se o programa tem alguma ligação com os projetos do MEC em relação à alimentação escolar, principalmente na África, Rondó afirmou que as diversas instituições que fornecem cooperação não conversam entre si o suficiente. Segundo ele, a retórica da cooperação brasileira é forte e tem valor, mas é preciso fazer o discurso se tornar ação ${ }^{290}$.

\subsubsection{Sintese}

Conforme observado acima, a cooperação brasileira para o desenvolvimento, em especial para a África, teve um notável acréscimo, seja em número de projetos, seja em orçamento e dispersão geográfica. A presença da diplomacia presidencial de Lula é apontada como relevante, principalmente na fala dos agentes brasileiros envolvidos na cooperação. Apesar do componente solidário inerente à cooperação Sul-Sul, a cooperação brasileira está fortemente vinculada à política externa, mesmo considerando os conceitos de horizontalidade

\footnotetext{
${ }^{289}$ Compilação a partir do sítio http://cooperacaohumanitaria.itamaraty.gov.br/acoes

${ }^{290}$ Rondó, Milton. Entrevista ao autor. Brasília, 08 de abril de 2016.
} 
e "demand-driven", ou seja, são os países africanos que apresentam demandas, não partindo do Brasil qualquer iniciativa para o início de um projeto. Para Pino, essa vinculação tem caráter instrumental: estaria conectada com a expectativa de retornos. $\mathrm{O}$ discurso solidário está subordinado a uma diplomacia de influência, apoiada na estratégia de associar as iniciativas de cooperação com o aumento de sua projeção no cenário internacional ${ }^{291}$.

$\mathrm{Na}$ entrevista com o gerente da Cooperação Sul-Sul com países africanos de língua portuguesa da $\mathrm{ABC}$, Paulo Lima, surge as limitações do sistema brasileiro, que não foram sanadas no período Lula. Em primeiro lugar, percebe-se que a $\mathrm{ABC}$ não funciona como uma agência, mas uma instância de coordenação burocrática interinstitucional, que busca gerenciar, recolher e sistematizar as informações e iniciativas para responder às demandas internacionais recebidas, algo que, segundo todos os entrevistados, aumentou de acordo com a abertura de novas embaixadas. Contudo, ao observarmos o mapa abaixo, ao destacar os países com maior número de projetos de cooperação e as embaixadas brasileiras estabelecidas por ano, essa relação não parece automática e direta.

Países como Angola, Moçambique, Argélia, Quênia, por exemplo, possuem embaixadas anteriores ao governo Lula e estão entre os maiores receptores de projetos. Benim, Burkina Faso e Mali são exemplos de embaixadas recentes com maior número de projetos, porém nesse caso estão ligados ao projeto Cotton-4. Não parece ter havido grande diferença, sendo os países com mais projetos aqueles com embaixadas mais antigas.

Entretanto, não é de se questionar que as embaixadas servem de canal de comunicação eficiente com os agentes de cooperação. Em segundo lugar, ligado ao primeiro ponto, a $\mathrm{ABC}$ não consegue atuar diretamente nos países recipientes, tendo que trabalhar com outros órgãos, como o PNUD, FAO e UNICEF para a execução de projetos. Segundo Paulo Lima, o orçamento da $\mathrm{ABC}$ basicamente cobre as despesas de passagens, diárias técnicas e equipamentos $^{292}$.

Desse modo, podemos avaliar que a dimensão cooperativa é um dos aspectos mais importantes das relações Brasil-África. No período do governo Lula, a ênfase nas relações Sul-Sul consequentemente conferiu mais atenção a essa dimensão, o que foi refletido no aumento do orçamento da $\mathrm{ABC}$ e a maior participação de outros órgãos do governo, na continuidade de projetos anteriores. No entanto, não houve continuidade nesse sentido, uma vez que o orçamento para a África passou a diminuir no pós-Lula e a $\mathrm{ABC}$ não recebeu nenhuma reforma institucional para ter mais participação na execução de projetos.

\footnotetext{
${ }^{291}$ Pino, 2012, p. 198.

${ }^{292}$ Lima, Paulo. Entrevista ao autor, Brasília, 5 de abril de 2016.
} 
Mapa 6 - Relação de embaixadas e países receptores de projetos

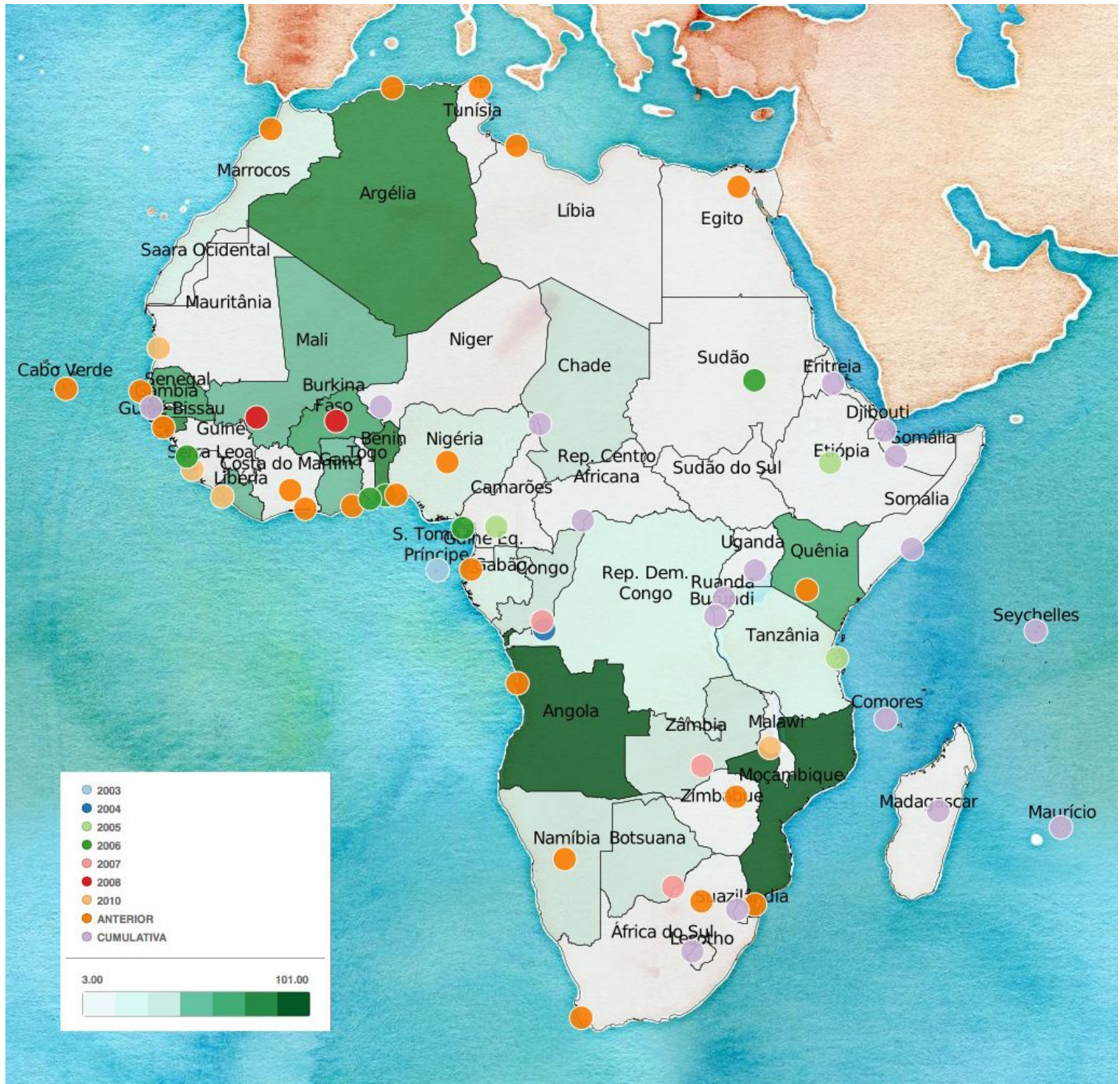

Fonte: elaboração própria a partir de www.abc.gov.br/Projetos/pesquisa 


\subsection{Dimensão Econômica}

Esse tópico tem o objetivo de analisar a dimensão econômica da política externa governo Lula em relação ao continente africano, abordando três aspectos. O primeiro é o perdão de dívidas bilaterais de países africanos pelo governo brasileiro. Optamos por colocar esse ponto neste tópico pois consideramos que o principal efeitos do perdão é econômico com a melhora da solvência externa dos países africanos, contribuindo para o crescimento econômico dos últimos $\operatorname{anos}^{293}$. O segundo aspecto a ser analisado é a área de investimentos brasileiros na África, com o crescimento da presença de empresas brasileiras em países africanos, em diversos setores.

\subsubsection{Perdão de Dívidas}

A questão do perdão de dívidas bilaterais normalmente gera controvérsia, sendo utilizada como argumento contra o governo Lula, e mais recentemente, em relação ao governo Dilma, que deu continuidade às negociações para a renegociação de dívidas ${ }^{294}$. Nesse subtópico, analisaremos o processo de perdão e renegociação de dívidas, a fim de levar o debate para fora do argumento batido de "ideologia".

Desde o fim da década de 1990, há uma iniciativa do Fundo Monetário Internacional com o objetivo de aliviar o peso de países em desenvolvimento altamente endividados, chamada Iniciativa HIPC (High Indebted Poor Countries) ${ }^{295}$. Essa iniciativa congrega os credores internacionais, que negociam tanto no âmbito do Clube de Paris quanto bilateralmente. Antes disso, as negociações ocorriam sob os termos de acordos anteriores, como o Acordo de Londres e de Nápoles. O Acordo de Colônia aprofunda os termos da Iniciativa $\mathrm{HIPC}^{296}$. O Brasil participa desde então como credor internacional de diversos países africanos, com quem contratou financiamento nas décadas de 70 e 80 para exportação de produtos brasileiros. Da lista de 39 países altamente endividados, 33 são africanos ${ }^{297}$.

\footnotetext{
${ }^{293}$ Como observou Denise Rodrigues e Ana Cláudio Caputo. O projeto de integração da África: aspectos físicos, comerciais, financeiros e de investimento. In: Revista do BNDES 41, junho de 2014, p. 101.

${ }^{294} \mathrm{O}$ Estado de S. Paulo. Perdão de às dívidas de países africanos soma US\$717 milhões. 21 de julho de 2013.

${ }^{295}$ HIPC Initiative (High Indebted Poor Countries: Países pobres altamente endividados): lançada em 1996, pelo FMI e Banco Mundial, com o objetivo de assegurar que nenhum país tenha uma dívida que não possa pagar. Desde então, a comunidade internacional, governos e organizações trabalham juntos para que as dívidas de países pobres cheguem a níveis sustentáveis. https://www.imf.org/external/np/exr/facts/hipc.htm

${ }^{296} \mathrm{http}$ ///www.clubdeparis.org/en/communications/page/standard-terms-of-treatment

${ }^{297}$ São eles: Benin, Burkina Faso, Burundi, Camarões, República Centro Africana, Chade, Comoros, República do Congo, RD Congo, Costa do Marfim, Eritreia, Etiópia, Gâmbia, Gana, Guiné, Guiné-Bissau, Libéria,
} 
Desde 2003, o Brasil participou como credor em 13 acordos de redução e cancelamento de dívidas no Clube de Paris, negociando dívidas com Congo-Kinshasa, Congo-Brazaville, Senegal, Gabão, Nigéria, Guiné-Conacri, Guiné-Bissau, Costa do Marfim ${ }^{298}$, como podemos ver na tabela abaixo. A tabela mostra que há uma constante negociação dos termos do reescalonamento; inclusive há negociações com a Nigéria e Moçambique, por exemplo, anteriores a 2003, e são negociadas em diferentes termos. No caso da Nigéria, a negociação seguiu bilateralmente e envolveu, além de um reescalonamento, o pagamento integral do restante da dívida.

Tabela 6 - Negociação de Dívidas do Brasil com países africanos no Clube de Paris

\begin{tabular}{|l|l|l|l|}
\hline Data de Negociação & Países & Tipo de Acordo & $\begin{array}{l}\text { Status } \\
\text { Negociação }\end{array}$ \\
\hline 29 de junho de 2012 & Costa do Marfim & Iniciativa HIPC & Ativo \\
\hline $\begin{array}{l}11 \text { de abril de } 2012 \\
2011\end{array}$ & Guiné & Acordo de Colônia & Ativo \\
\hline $\begin{array}{l}17 \text { de novembro de } \\
2010\end{array}$ & Costa do Marfim & Acordo de Colônia & Ativo \\
\hline 6 de julho de 2010 & Guiné-Bissau & Acordo de Colônia & Ativo \\
\hline $\begin{array}{l}18 \text { de março de } 2010 \\
25 \text { de fevereiro de } 2010\end{array}$ & Rep. do Congo & Iniciativa HIPC & Ativo \\
\hline 15 de maio de 2009 & Costa do Marfim & Acordo do Congo Colônia & Ativo \\
\hline $\begin{array}{l}11 \text { de dezembro de } \\
2008\end{array}$ & Rep. do Congo & Acordo de Colônia & Ativo \\
\hline 23 de janeiro de 2008 & Guiné & Ativo \\
\hline 09 de março de 2006 & Rep. do Congo & Acordo de Colônia & Ativo \\
\hline 20 de outubro de 2005 & Nigéria & Ad Hoc & $\begin{array}{l}\text { Pagamento } \\
\text { Integral }\end{array}$ \\
\hline $\begin{array}{l}11 \text { de junho de } 2004 \\
2004\end{array}$ & Gabão & Acordo de Colônia & Ativo \\
\hline
\end{tabular}

Madagascar, Malaui, Mali, Mauritânia, Moçambique, Níger, Ruanda, São Tomé e Príncipe, Senegal, Serra Leoa, Somália, Sudão, Tanzânia, Togo, Uganda, Zâmbia. https://www.imf.org/external/np/exr/facts/hipc.htm

${ }^{298}$ Todas as negociações podem ser consultadas em http://www.clubdeparis.org/en/sections/pays-creancier/brazil 


\begin{tabular}{|l|l|l|l|}
\hline 9 de junho de 2004 & Senegal & Iniciativa HIPC & Ativo \\
\hline $\begin{array}{l}22 \text { de novembro de } \\
2003\end{array}$ & Rep. Dem. do Congo & Acordo de Colônia & Ativo \\
\hline
\end{tabular}

Fonte: Elaboração própria a partir de http://www.clubdeparis.org/en/sections/pays-creancier/brazil

O processo também possui um curso interno. Após a negociação, bilateral ou via Clube de Paris, os termos da mesma são discutidos em reuniões na alçada do Ministério da Fazenda, mais exatamente no órgão colegiado do Comitê de Avaliação de Créditos ao Exterior (COMACE). A Secretaria executiva desse comitê é encabeçada pela Secretaria de Assuntos Internacionais (SAIN), tendo como membros Procuradoria-Geral da Fazenda Nacional (PGFN), Secretaria do Tesouro Nacional, Ministério das Relações Exteriores, Ministério do Planejamento, Orçamento e Gestão, Banco Central e Banco do Brasil. Após o parecer desse comitê, o Ministro da Fazenda encaminha os termos da negociação e motivos para a Presidência da República, que por sua vez envia ao Senado Federal por meio do instrumento chamado "Mensagem ao Senado Federal", solicitando a aprovação com base nos pareceres técnicos. No Senado, o processo é discutido na Comissão de Assuntos Econômicos (CAE), que o transforma em Projeto de Resolução do Senado. Uma vez discutido e aprovado, a Comissão torna a decisão norma jurídica por meio de Resolução do Senado, sem passar em plenário. Esse trâmite processual segue o rito da Lei 9.665/98, que autoriza o poder executivo conceder remissão parcial a créditos a outros países, e do artigo 52, inciso $\mathrm{V}$ da Constituição Federal, pelo qual compete ao Senado Federal autorizar operações externas de natureza financeira. Não é, portanto, um caminho "ideológico" para o perdão e renegociação de dívidas externas, tendo em vista a quantidade de atores e agentes, a maioria dos quais técnicos, ao longo processo. Ainda, segundo essa lei, o Brasil não pode conceder remissão total de dívidas, como às vezes ocorre nas negociações do Clube de Paris.

A partir dos processos em tramitação na Comissão de Assuntos Econômicos do Senado, foi possível organizar a tabela abaixo com os dados dos países africanos com os quais o Brasil renegociou seus créditos, e seus montantes, durante o período analisado. De todos os devedores em relação ao Brasil, dentre os africanos, apenas Guiné-Conacri não aparece na lista, pois as negociações não se encerraram. Dentro do âmbito do Clube de Paris, a Guiné recebeu $100 \%$ de perdão, mas a legislação brasileira não permite a remissão total, apenas parcial, e portanto espera a retomada das negociações ${ }^{299}$. Como dito, as negociações começaram em sua maioria já na década de 90 , mas o processo como um todo não é imediato.

${ }^{299}$ Ata da 31a Reunião da COMACE, de 01.03.2013, p. 77. 
Durante o período Lula, o perdão de dívidas de 3 países foi aprovado no Senado: Moçambique, Nigéria e Cabo Verde, numa dívida total de US\$487 milhões, e remissão de cerca US\$400 milhões. Os outros países que constam dessa lista tiveram negociações ao longo do período, mas o processo interno de aprovação ocorreu após o período Lula.

A tabela abaixo mostra as negociações de dívidas com todos os países africanos no governo Lula. Os 3 países citados, os quais o governo Lula aprovou o perdão de dívida, também tinha em andamento negociações nesse sentido antes desse período, tanto que Fernando Henrique chegou a mencionar, no final de seu mandato, que havia determinado o perdão da dívida de Moçambique. A coluna do ano de aprovação refere-se ao fim do processo interno, depois das rodadas de negociação, cujos anos aparecem em parênteses. Nem todos os países tem um perdão alto, restando a reescalonação de parte da dívida.

Tabela 7 - Relação de Perdão de Dívidas e Renegociação com países africanos

\begin{tabular}{|c|c|c|c|c|}
\hline País & $\begin{array}{l}\text { Ano de } \\
\text { aprovação } \\
\text { (negociação) }\end{array}$ & Dívida & Perdão & Renegociação \\
\hline Moçambique & 2005 & US\$331.686.015,65 & $\begin{array}{l}\text { US\$315.101.714,87 } \\
(95 \%)\end{array}$ & US\$16.584.300,78 \\
\hline Nigéria & 2006 & US\$151.953.792,35 & $\begin{array}{l}\text { US\$84.660.006,35 } \\
(55 \%)\end{array}$ & US\$67.293.786,00 \\
\hline Cabo Verde & 2010 & US $\$ 3.895 .163,33$ & $\begin{array}{l}\text { US\$1.197.962,40 } \\
(30 \%)\end{array}$ & US\$2.697.200,93 \\
\hline Gabão & 2013 (2004) & US\$27.654.760,40 & $\begin{array}{l}\text { US } \$ 3.569 .644,62 \\
(13 \%)\end{array}$ & US\$24.085.115,78 \\
\hline Senegal & 2013 (2004) & US\$6.569.351,22 & $\begin{array}{l}\text { US } \$ 2.969 .804,75 \\
(45,2 \%)\end{array}$ & US\$3.599.546,47 \\
\hline Sudão & $2013(2010)$ & US\$43.581.141,68 & $\begin{array}{l}\text { US\$39.223.027,52 } \\
(90 \%)\end{array}$ & US\$4.358.114,16 \\
\hline $\begin{array}{l}\text { República do } \\
\text { Congo }\end{array}$ & $2013(2004)$ & US\$352.676.103,62 & $\begin{array}{l}\text { US\$278.087.640,64 } \\
(79 \%)\end{array}$ & US\$74.588.462,98 \\
\hline $\begin{array}{l}\text { São Tomé e } \\
\text { Príncipe }\end{array}$ & $2013(2010)$ & US $\$ 4.323 .293,85$ & $\mathrm{US} \$ 0$ & US $\$ 4.323 .293,85$ \\
\hline $\begin{array}{ll}\text { Costa } & \text { do } \\
\text { Marfim } & \end{array}$ & 2013 (2009) & US $\$ 9.045 .635,40$ & $\begin{array}{l}\text { US\$7.782.778,80 } \\
(86,04 \%)\end{array}$ & US\$1.262.856,60 \\
\hline Guiné Bissau & (2010) & US\$38.849.734,40 & $\begin{array}{l}\text { US\$36.907.247,68 } \\
(95 \%)\end{array}$ & US\$1.942.486,72 \\
\hline Mauritânia & 2002 & US\$10.477.123,33 & US\$0 & US\$10.477.123,33 \\
\hline RD Congo & $2013(2003)$ & US $\$ 4.761 .470,98$ & $\begin{array}{l}\text { US\$2.555.661,61 } \\
(54 \%)\end{array}$ & US $\$ 2.205 .809,37$ \\
\hline Tanzânia & $2013(2002)$ & US\$236.996.036,19 & $\begin{array}{l}\text { US\$203.609.713,65 } \\
(86 \%)\end{array}$ & US\$33.386.322,54 \\
\hline Zâmbia & $2013(2002)$ & US\$113.423.004,53 & US\$90.738.403,62 & US\$22.684.600,91 \\
\hline
\end{tabular}




\begin{tabular}{|l|l|l|l|l|}
\hline & & & $(80 \%)$ & \\
\hline Totais & & US\$1.335.892.626,93 & US\$1.066.403.606,51 & US\$269.489.020,42 \\
\hline $\begin{array}{l}\text { Total 2003- } \\
2010\end{array}$ & & US\$487.534.971,33 & US\$400.959.683,62 & US\$86.575.287,71 \\
\hline
\end{tabular}

http://www25.senado.leg.br/web/atividade/materias . Em parênteses, ano do acordo de negociação.

Praticamente todas as dívidas são oriundas do antigo programa brasileiro de financiamento de exportação, o Fundo de Financiamento às Exportações (FINEX), que foi absorvido pelo Programa de Financiamento às Exportações (PROEX), em 1991, cujos créditos foram concedidos na década de 1970 e 1980. Apenas no caso de São Tomé e Príncipe os créditos foram tomados em 2007, os mais recentes, também via PROEX, já dentro do âmbito da cooperação Sul-Sul e estreitamento das relações do países da CPLP e a negociação do reescalonamento ocorreu em âmbito bilateral ${ }^{300}$. Os objetivos santomenses com o empréstimo era a compra de alimentos, o apoio à iniciativa privada, a criação de empregos e o alargamento da base tributária. Mas, segundo os próprios representantes na negociação, o crédito "tomou outros contornos e acabou beneficiando apenas o setor privado, sem alcançar qualquer um dos objetivos mencionados". Inicialmente, os santomenses solicitavam a transformação do crédito em doação. Depois de longa negociação, as partes concordaram em novo cronograma de reescalonamento. Os outros casos todos foram negociados em primeira instância no Clube de Paris.

A tabela 7 contempla todas as negociações, mesmo em andamento, não apenas as que foram aprovadas entre 2003 e 2010 estudado, pois novas rodadas de negociações ocorreram então, como notado, dentro do pensamento da cooperação internacional para o desenvolvimento. Além disso, as atividades do COMACE foram intensificadas durante o governo Lula, tendo em mente a prioridade do continente africano na política externa brasileira naquele momento, como consta explicitamente em uma das atas daquele órgão: "A iniciativa [de renegociação] alinha-se com a prioridade que as relações com a África assumem na política externa brasileira e contribuem com o momento positivo por que vem passando aquele continente, ${ }^{, 301}$.

No gráfico 7 abaixo, podemos observar a relação entre dívida externa e PIB de Nigéria, Moçambique e Cabo Verde. Nigéria e Moçambique tiveram visíveis reduções da dívida externa entre 2005 e 2006, anos do perdão da dívida com o Brasil e com outros credores. Cabo Verde, em 2010, não mostra tanta diferença, já que o perdão brasileiro é

\footnotetext{
${ }^{300}$ Parecer n. 288/2013 da Procuradoria Geral da Fazenda Nacional

${ }^{301}$ Nota técnica COMACE n. 530, 10.12.2012.
} 
menor e relativamente pequeno quanto à dívida externa geral ${ }^{302}$. A iniciativa, no entanto, não representa uma vantagem econômica ou financeira imediata nem para o Brasil, nem para os países endividados. O próprio presidente Lula tem consciência disso, quando discursou no Fórum Econômico Mundial, em Davos, 2005:

"Não temos muito mais o que perdoar, porque também não temos muito. Agora, a verdade é que esses países já não podiam pagar. Então, é um perdão de uma coisa que as pessoas não podiam pagar. Eles já não estavam pagando; na verdade, foi um benefício que não teve resultado imediato para aquele país que recebeu. ${ }^{303,}$

Gráfico 7 - Relação Dívida Externa e PIB (em \%)

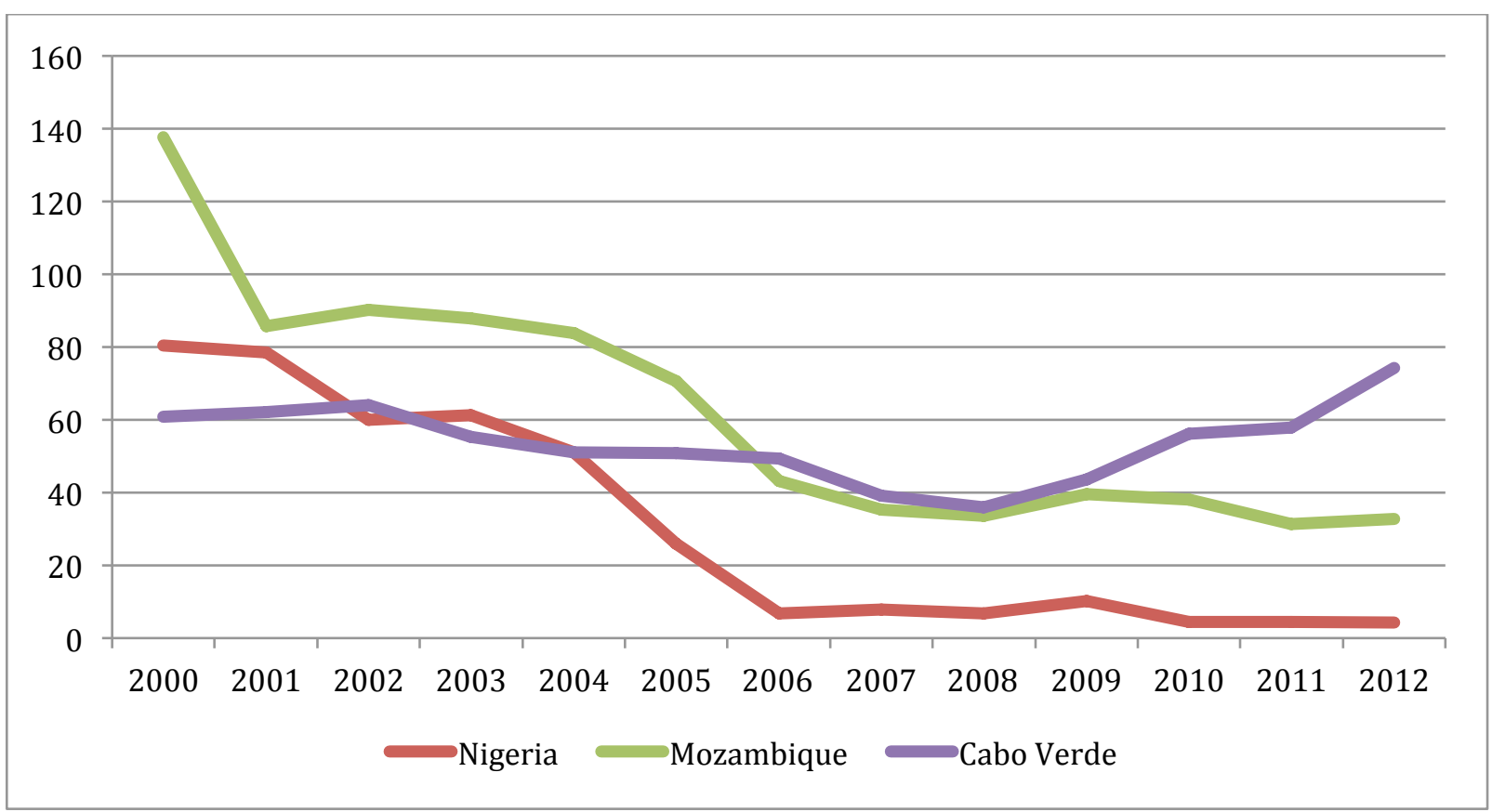

Fonte: Elaboração própria a partir de data.worldbank.org

Ainda assim, o movimento se encaixa em duas orientações da política externa de Lula, que não deixam de estar dentro da cooperação internacional. O primeiro é um movimento geral da comunidade internacional para buscar os objetivos do milênio, no qual o perdão de dívidas se encaixaria na meta 15 do $8^{\circ}$ objetivo; o segundo é um movimento que toma força na administração Lula, de retomada do comércio com os países endividados como forma de estimular o desenvolvimento desses países e a partir daí encontrarem mais força para escapar

\footnotetext{
${ }^{302}$ Banco Mundial. International Debt Statistics 2016, p. 44.

${ }^{303}$ Discurso do Presidente Lula no Fórum Econômico Mundial em Davos, 28.01.2005. In: MRE. Resenha de Política Externa do Brasil, n. 96, 2005, p. 46.
} 
da tendência estrutural de endividamento ${ }^{304}$. Isso vai ao encontro do interesse brasileiro de aumentar oportunidades de empréstimo, considerando que a renegociação de dívidas é condição para estabelecer novas linhas de crédito, por parte das instituições financeiras brasileiras $^{305}$.

Diante desse cenário, observamos que o perdão de dívidas, além de influenciar a capacidade econômica dos países envolvidos, também tem espaço tanto na dimensão política, com o fortalecimento da posição geopolítica, quanto na dimensão cooperativa, pois se encaixa na esfera da cooperação internacional para o desenvolvimento. O perdão de dívidas não é um ato unilateral brasileiro, mas antes uma ação conjunta de diversos países, inclusive países centrais. Todavia, devido ao longo processo interno, a ausência de um governo interessado em levar adiante as negociações teria dificultado o avanço das medidas. No caso, a vontade política do governo Lula beneficiou o avanço do trâmite interno.

\subsubsection{Investimentos}

Uma esfera relevante da dimensão econômica das relações entre o Brasil e o continente africano é a de investimentos. Tanto a África aumenta sua atração de investimentos quanto o Brasil aumenta a internacionalização de seu setor produtivo, ambos dentro de um cenário macroeconômico favorável.

A maior parte dos investimentos se concentra em áreas de extração de recursos minerais, refletindo os dois tipos de empresas brasileiras com presença na África: as grandes empresas - Petrobras, Vale, Odebrecht - que atuam na África desde final da década de 70 e década de 80; e médias empresas, que recentemente se aproximaram do continente ${ }^{306}$. Entretanto, mesmo considerando o aumento do investimento brasileiro, a maior participação de investimento na África permanece com países europeus, e, mais recentemente, com emergentes como a China e Índia.

A análise dos investimentos diretos brasileiros esbarra, como em outras áreas, na dificuldade ao acesso de informações. No caso dos investimentos diretos no exterior, o Banco Central realiza um levantamento anual sobre o estoque de capital brasileiro no exterior, porém a maioria das declarações indica paraísos fiscais como destino dos ativos, dificultando a

\footnotetext{
${ }^{304}$ Segundo o Relatório Nacional para os Objetivos do Milênio, o Brasil, entre 2005 e 2010 renegociou dívidas com países pobres no montante de US\$1 bilhão. Presidência da República, Relatório Nacional de Acompanhamento 2010, p. 159.

${ }^{305}$ Pedro da Motta Veiga. A África na agenda econômica do Brasil: comércio, investimentos e cooperação. In: Revista Brasileira de Comércio Exterior, n. 116, 2013, p. 16.

${ }^{306}$ IPEA. Ponte Sobre o Atlântico, 2012, p. 83.
} 
identificação do real destino final e subestimando os números referente à África. No levantamento feito nesses dados, no período 2006-2010, apenas África do Sul e Guiné Equatorial receberam diretamente investimentos diretos, desconsiderando Seychelles e outros paraísos fiscais:

Tabela 8 - Saídas de investimentos brasileiros diretos

\begin{tabular}{|c|c|c|c|c|c|c|}
\hline & Discriminação & 2006 & 2007 & 2008 & 2009 & 2010 \\
\hline 1 & Estados Unidos & 999 & 3548 & 4786 & 1780 & 3958 \\
\hline 4 & Países Baixos & 303 & 115 & 387 & 428 & 3314 \\
\hline 7 & Ilhas Cayman & 3176 & 2701 & 2137 & 2223 & 11647 \\
\hline 11 & Ilhas Virgens Britânicas & 990 & 954 & 712 & 441 & 830 \\
\hline 13 & Bahamas & 1418 & 995 & 806 & 279 & 829 \\
\hline 16 & Suíça & 78 & 76 & 121 & 52 & 273 \\
\hline 17 & Luxemburgo & 3 & 49 & 277 & 235 & 1342 \\
\hline 18 & Panamá & 54 & 36 & 3079 & 57 & 859 \\
\hline 21 & África do Sul & - & - & 25 & - & 0 \\
\hline 23 & China & 13 & 14 & 15 & 3 & 14 \\
\hline 24 & Alemanha & 1 & 8 & 332 & 2 & 28 \\
\hline 27 & Bermudas & 24 & 362 & 25 & 6 & 734 \\
\hline 31 & Ilhas Virgens (EUA) & 1 & 5 & 2 & 5 & 4 \\
\hline 37 & Belize & 3 & - & - & 3 & 4 \\
\hline 38 & Ilhas Jersey & - & 6 & 230 & - & - \\
\hline 40 & Antilhas Holandesas & 72 & 403 & 562 & 42 & 1 \\
\hline 41 & Seychelles & 2 & - & - & - & - \\
\hline 48 & Guiné Equatorial & - & 1 & 2 & - & - \\
\hline \multirow[t]{2}{*}{49} & Demais países & 411 & 497 & 809 & 742 & 96 \\
\hline & Total & 24416 & 12135 & 18028 & 8462 & 30228 \\
\hline
\end{tabular}

Fonte: Banco Central do Brasil. A tabela mostra apenas os montantes acima de US\$1 milhão

Além dessa tabela, o IPEA apresentou dados que mostram Angola como grande recipiente de investimento direto brasileiro na África: 
Tabela 9 - Investimentos diretos brasileiros no exterior a países africanos 2003-2009

\begin{tabular}{|l|l|l|l|l|l|l|l|}
\hline & 2003 & 2004 & 2005 & 2006 & 2007 & 2008 & 2009 \\
\hline África do Sul & - & - & 0 & 2 & - & - & - \\
\hline Angola & 22 & 24 & 17 & 20 & 73 & 58 & 124 \\
\hline
\end{tabular}

Fonte: IPEA. Ponte para o Atlântico

Em relação ao investimento de empresas, a instituição Fundação Dom Cabral elabora relatórios sobre as empresas transnacionais brasileiras desde 2007, fornecendo algumas informações que são úteis, porém incompletas, sobre a participação brasileira nos investimentos na África. Segundo o relatório relativo ao ano de 2010, o continente africano estava como o quinto local onde mais empresas brasileiras estavam sediadas, mais precisamente em 21 países $^{307}$.

Na mesma medida, a presença da África como destino das empresas foi a terceira que mais aumentou nos anos analisados pelos relatórios da Fundação. Apesar de não constar o montante investido pelas empresas, os relatórios trazem um elemento que ajuda a quantificar a presença das empresas brasileiras no continente africano, considerando ainda que esses documentos não abarcam a totalidade das empresas, mas apenas as maiores e as que respondem aos questionários da Fundação. Nesse sentido, os relatórios apresentam o Índice de Regionalidade, que equivale ao número de países em determinada região dividido pelo número de países em que a empresa está presente nessa região.

A partir desses dados, podemos observar que o continente africano só está na frente da Oceania como macro região recipiente de investimentos empresariais brasileiros. A América Latina, no período disponível, sempre liderou a atração dos investimentos empresariais, seguida da Europa, Ásia e América do Norte. No caso da África, houve um queda forte de 2007 para 2008, que foi recuperada nos anos seguintes, sendo que em 2010 foi o ano com mais presença de empresas brasileiras na África. Com base nos dados dos relatórios da Fundação Dom Cabral, também foi possível congregar os índices de regionalidade das empresas brasileiras no período, conforme tabela abaixo. Segundo o IPEA, as pequenas e médias empresas estão concentradas em Angola, onde a Agência Brasileira de Promoção de Exportações (APEX) abriria um centro de negócios, em 2010.

\footnotetext{
${ }^{307}$ Fundação Dom Cabral. Ranking das Transnacionais Brasileiras 2011, p. 27. Os países são África do Sul, Moçambique, Angola, Mali, Líbia, Libéria, Mauritânia, Marrocos, Guiné-Conacri, Guiné Equatorial, Tunísia, Gabão, Malauí, Egito, Congo, Zâmbia, Cabo Verde, Nigéria, Argélia, Quênia e Camarões.
} 
Tabela 10 - Índice de Regionalidade por empresa brasileira na África

\begin{tabular}{|l|l|l|l|l|l|}
\hline & 2006 & 2007 & 2008 & 2009 & 2010 \\
\hline Média bras. na África & 6.7 & 8.3 & 4.66 & 5.43 & 9.6 \\
\hline Vale & 10 & 11 & 21 & 21 & 24 \\
\hline Petrobras & 22 & 29 & 24 & 19 & 15 \\
\hline Camargo Correa & 17 & 23 & 18 & 14 & 11 \\
\hline Odebrecht & 17 & 21 & 31 & 24 & 23 \\
\hline Weg & 8 & - & - & - & 4 \\
\hline Marcopolo & 14 & 22 & 22 & 29 & 15 \\
\hline Randon & - & 33 & 40 & 30 & 36 \\
\hline Andrade Gutierrez & - & 18 & 18 & - & 24 \\
\hline Banco do Brasil & - & - & 17 & 4 & 4 \\
\hline Votorantim & - & - & - & 24 & 17 \\
\hline Stefanini IT Solutions & - & - & - & 6 & 3 \\
\hline Marfrig & - & - & - & 8 & - \\
\hline Totvs & - & - & - & 10 & - \\
\hline Escolas FISK & - & - & - & 17 & - \\
\hline Minerva & - & - & - & - & 22 \\
\hline
\end{tabular}

Fonte: Elaboração própria a partir de Fundação Dom Cabral. Ranking das transnacionais brasileiras 2007-2011.

As empresas brasileiras de maior presença na África estão concentradas nos setores de mineração, construção civil e exploração de petróleo. Esses "agentes tradicionais" são especificamente Andrade Gutierrez, Camargo Correa, Odebrecht, Petrobras, Queiroz Galvão e Vale $^{308}$. Segundo Vieitas e Aboim, essa concentração ocorre pela dificuldade institucional e logística de concretização de negócios nos países africanos, mas os grandes projetos dessas empresas têm atraído outras de menor porte, que representam cadeias de fornecedores para esses projetos $^{309}$. No Mapa 3 podemos observar a distribuição geográfica da presença das empresas brasileiras no continente africano, de acordo com o IPEA. Como já dito, a Dom Cabral aponta 21 países onde empresas brasileiras atuam na África, enquanto Vieitas e Aboim apontam para 27 locais. A concentração, refletindo a concentração por setor, está na África Meridional - África do Sul, Namíbia, Angola e Moçambique - e na África Setentrional, especificamente no Egito e na Líbia, mas também Argélia, Tunísia e Marrocos.

\footnotetext{
${ }^{308}$ IPEA, op. cit., p. 87.

${ }^{309}$ VIEITAS, Deborah e ABOIM, Isabel. África: Oportunidades para empresas brasileiras. In: Revista Brasileira de Comércio Exterior n. 116.
} 
O relatório do IPEA sobre as relações Brasil-África observa que a presença de empresas brasileiras a África se notabiliza pelo modelo de negócios. As empresas brasileiras tentariam incluir mão de obra local para os projetos e desenvolver capacidades, a fim de melhorar serviços e produtos. Reflexo disso é o dado de que a Odebrecht é a maior empregadora do setor privado em Angola ${ }^{310}$. Além disso, a Odebrecht, ao final do governo Lula, era a empresa brasileira com maior número de projetos no continente, presente na África do Sul, Angola, Botsuana, Djibouti, Gabão, Líbia, Libéria, Moçambique e República Democrática do Congo, nos setores de petróleo, infraestrutura, construção civil e planejamento urbano, extração de diamantes e distribuição de alimentos ${ }^{311}$.

\footnotetext{
${ }^{310}$ IPEA, op. cit., p. 87.
}

${ }^{311}$ Idem, p. 88. 
Mapa 7 - Distribuição geográfica das empresas brasileiras na África

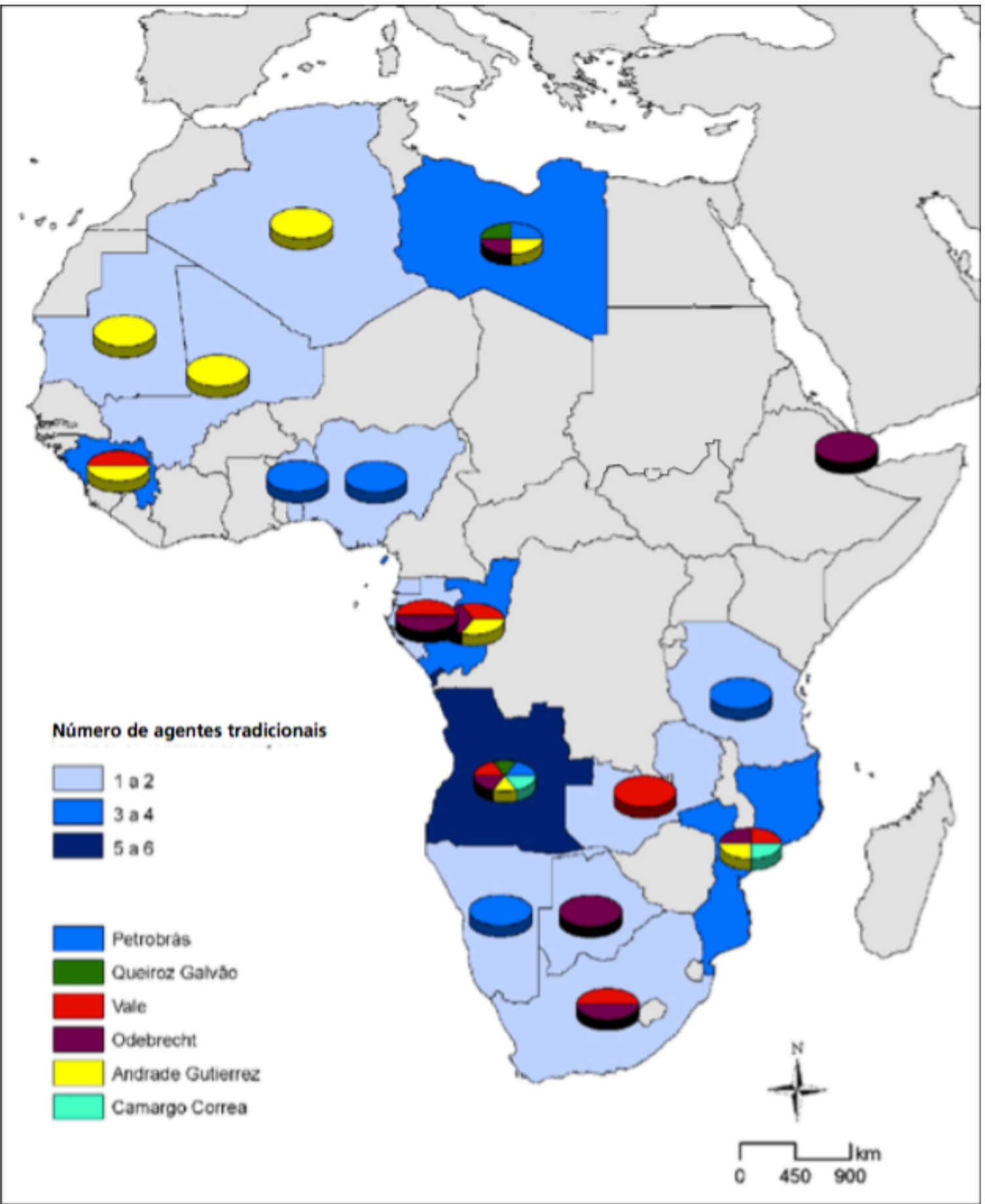

Fonte: IPEA, Ponte sobre o Atlântico, p. 88.

O Banco Nacional de Desenvolvimento Econômico e Social (BNDES) é o principal provedor de recursos para as empresas brasileiras na África, principalmente pela abertura de linhas de crédito, por meio de programa de financiamento a exportações. O financiamento a exportações é estimulado sobretudo pelo Programa de Financiamento às Exportações (PROEX) gerido pelo Banco do Brasil. Por meio de pesquisa no sistema do BNDES, foi possível encontrar operações de investimento na África, em apoio a empresas brasileiras, 
conforme a tabela abaixo. No período analisado, as operações concentraram-se em Angola, num montante de US\$ 1,6 bilhão. Os projetos são sobretudo de construção civil, como serviços de construção de centros de tecnologia e escolas, de infraestrutura rodoviária, obras de aproveitamento e transporte hidrelétrico e de abastecimento de água.

Tabela 11 - Operações de financiamento do BNDES na África

\begin{tabular}{|l|l|r|r|}
\hline Empresa & País & Montante (USD) & \\
\hline Camargo Correa & Angola & $149,440,908$ & $2007 / 2009$ \\
\hline Andrade Gutierrez & Angola & $184,131,778$ & $2007-2009$ \\
\hline Odebrecht & Angola & $1,109,679,874$ & $2007-2009$ \\
\hline Queiroz Galvão & Angola & $188,378,688$ & $2007 / 2008$ \\
\hline EMSA & Angola & $19,107,566$ & 2008 \\
\hline Prado Valladares & Angola & $5,055,043$ & 2007 \\
\hline Mello Junior & Angola & $15,006,750$ & 2008 \\
\hline Total & & $1,670,800,606$ & \\
\hline
\end{tabular}

http://www.bndes.gov.br/SiteBNDES/bndes/bndes_pt/Institucional/BNDES_Transparente/consulta_as_operacoe s_exportacao/painel_consulta_pos_embarque_obras.html

Em Angola, a presença de empresas brasileiras remonta à década de 1980, com a chegada da Petrobras e Odebrecht. Na exploração de petróleo, a empresa é sócia de 6 blocos e, a partir de 2006, operadora em outros 3. Também tem projetos de exploração de óleo e gás.

A Odebrecht começou suas operações em Angola com a construção da Hidrelétrica de Capanda e até hoje atua em projetos de infraestrutura rodoviária, e nos setores imobiliário, de mineração, de energia e agronegócios.

Já a Vale está em Angola desde 2005, e atua em conjunto com uma empresa angolana, sobretudo na extração de níquel e cobre. Também presente desde 2005, a Andrade Gutierrez atua na construção de infraestrutura rodoviária e possui projeto de ampliação do aeroporto de Luanda. A Camargo Correa, também na área de infraestrutura rodoviária, está presente desde que inaugurou escritório comercial em Luanda em $2005^{312}$.

Moçambique, por sua vez, tornou-se atraente para projetos de extração de recursos naturais e energia, com enormes reservas de carvão e gás e potencial elétrico. A localização do país também é atraente, com portos voltados para a China e Índia, que, com o potencial de comércio do Oceano Índico, pode servir de concentração de comércio dos países vizinhos,

\footnotetext{
${ }^{312}$ Vieitas e Aboim. P. 27-28.
} 
como a África do Sul. O potencial elétrico é relevante pela possibilidade de venda de excedente para a África do Sul. No final do período Lula, o Brasil representava cerca de $42 \%$ dos investimentos externos no país. Esse cenário reflete a concentração de empresas brasileiras no setor exploração e produção de petróleo, mineração, agroindústria e construção civil. A Petrobras está presente também no setor de biocombustível, com participação em uma usina de açúcar.

No caso de mineração, a Vale está presente desde 2004, com a concessão de exploração da mina de carvão de Moatize. A produção se iniciou em 2011. Além disso, a Vale investe na expansão ferroviária do chamado corredor de Nacala, que inclusive passa pelo país vizinho de Malaui, para o escoamento da produção de carvão. A Odebrecht trabalha em conjunto com a Vale para a construção da infraestrutura da mina de Moatize, além de obras de estrutura civil, como rodovias. Em 2011, a Odebrecht foi contratada para a construção do aeroporto de Nacala. A Andrade Gutierrez também trabalha em torno da operação de Moatize, com a construção do porto de Nacala, assim como a Camargo Gutierrez trabalha com a extração de carvão, além da construção da usina hidrelétrica no rio Zambeze. Por fim, também presentes estão a OAS e Queiroz Galvão, atuando em prestação de serviços de saneamento e infraestrutura de transportes ${ }^{313}$.

O investimento brasileiro na África, portanto, está concentrado, ainda, na exploração de recursos naturais mas também em infraestrutura. As grandes empresas estão presentes desde o final da década de 70, como o caso da Petrobras, seguidas na década de 80 pela Odebrecht, Vale e outras, concentradas em grandes projetos. As pequenas e médias empresas migraram apenas nos últimos anos. Os empresários citam as dificuldades, como logística, burocracia, falta de transparência, como os principais empecilhos dessa migração. A concentração em países de língua portuguesa também fica evidente na análise. Para Veiga, o crescimento do investimento brasileiro na África pode ser creditado parcialmente ao “ativismo" brasileiro na década de Lula - apesar de ser difícil de comprovado na questão dos investimentos. Nota-se que o aumento da presença estatal, com a aproximação diplomática, por exemplo, beneficia a chegada de empresas, pois cria um ambiente favorável e receptivo, ajudando a ultrapassar algumas barreiras. Entretanto, Veiga afirma que além da prioridade da África nos instrumentos de política, nada foi feito para estimular os investimentos diretos especificamente para o continente africano, como acordos de proteção ao investimento ${ }^{314}$. Os

\footnotetext{
${ }^{313}$ Idem, p. 29-31.

${ }^{314}$ Pedro da Motta Veiga. A África na agenda econômica do Brasil: comércio, investimentos e cooperação. In: Revista Brasileira de Comércio Exterior, n. 116, 2013, p. 17-18.
} 
chamados Acordos para Promoção e Proteção de Investimentos (APPI), que buscam proteger e garantir os investimentos feitos em determinado país, assinados pelo Brasil desde 1994 não contemplaram países africanos $^{315}$. Apenas em 2015, já no governo Dilma Rousseff, um novo modelo de regulação, no contexto Sul-Sul, foi estabelecido, com os Acordos de Cooperação e Facilitação de Investimentos (ACIFs), com base em melhoria de governança global, cooperação e facilitação de investimentos, e mecanismos de mitigação de riscos e prevenção de controvérsias. Até abril de 20167 acordos foram firmados, entre eles com Angola, Moçambique e Malaui. Até julho desse ano, os textos estavam em tramitação no Senado ${ }^{316}$.

\subsubsection{Esfera comercial}

O intercâmbio comercial entre o Brasil e o continente africano cresceu de maneira expressiva no período do governo Lula. Além das visitas empreendidas pelo presidente, que eram acompanhadas por delegações de empresários, o Ministério das Relações Exteriores, em conjunto com o Ministério do Desenvolvimento (MDIC) e a Agência Brasileira de Promoção de Exportação (APEX), realizaram diversos eventos de promoção, como uma missão empresarial ao norte da África e a África subsaariana; a realização de um Fórum "BrasilÁfrica Subsaariana: Empreendedorismo para o Desenvolvimento"; exposição de maquinários agrícolas; participação em feiras, como a Feira Internacional de Lomé, de Bamako e de Luanda ${ }^{317}$.

Mas, paralelamente, outros elementos devem ser considerados na análise dessas relações para se ter a exata noção de sua evolução. Não apenas o fluxo comercial com a África cresceu, mas o intercâmbio do Brasil com o mundo e também o da própria África. O objetivo deste tópico é ir mais a fundo na análise dessas relações comerciais, buscando investigar quais são os principais parceiros brasileiros na África, quais são os principais produtos comercializados, e quais são as principais características dessas trocas, para, enfim, empreender uma interpretação das relações comerciais. A hipótese a ser investigada nesse tópico se trata de que o comércio com a África cresceu em termos absolutos mas não em termos relativos, o que permite que os dados sejam manipulados e utilizados tanto por

\footnotetext{
${ }^{315}$ Os 14 países que celebraram esse tipo de acordo foram: Bégica, Países Baixos, Canadá, Cuba, Alemanha, Coreia do Sul, Venezuela, Dinamarca, Itália, Finlândia, França, Suíça, Reino Unido e Chile. MRE. Departamento de Atos Internacionais. http://dai-mre.serpro.gov.br. Acessado em 25 de junho de 2016.

${ }_{316}$ Observatório Brasil e o Sul. Acordos de cooperação e facilitação de investimentos (ACIF) do Brasil. Disponível em http://obs.org.br/comercio-e-investimento/1073-acordos-de-cooperacao-e-facilitacao-deinvestimento-acfis-do-brasil , acessado em 14 de julho de 2016.

${ }^{317}$ Visentini, Paulo Fagundes. A Projeção Internacional do Brasil 1930-2012. Rio de Janeiro: Elsevier, 2013, p. 123.
} 
defensores quanto por críticos da política externa para a África. Ao fim, poderemos também observar se houve alguma mudança em relação à concentração de produtos na pauta comercial e em parceiros comerciais, como se apresentou em momentos anteriores.

Começando pelos dados mais gerais, o fluxo comercial entre Brasil e África, de acordo com os dados pesquisados no sistema AliceWeb, da Secretária de Comércio Exterior, do Ministério do Desenvolvimento, Indústria e Comércio Exterior, aumentou continuamente entre 2003 e 2010, saindo do patamar de US\$ 6,138 bilhões para US\$ 20,564 bilhões, conforme o gráfico 8 abaixo. Por si só, é um número significativo, pois demonstra um aumento de mais de 3 vezes, crescimento muito superior ao do período anterior. O período imediatamente anterior, como aponta Ribeiro ${ }^{318}$, de 1996 a 2002, também contou com aumento desse comércio, nem sempre contínuo, mas registrando em 2002 um aumento de 43\% (US\$5,04 bilhões) em relação a 1997 (US\$3,5 bilhões) ${ }^{319}$.

O saldo da balança comercial com o continente africano, no entanto, é deficitário em praticamente todo o período, com exceção de 2009, cujo resultado foi um pequeno superávit de US\$226 milhões, provavelmente como reflexo da crise financeira de 2008, quando a capacidade de exportação africana diminuiu quase pela metade, enquanto a exportação brasileira para o continente sofreu menor diminuição. O maior déficit ocorreu em 2008, no auge das relações comerciais, no valor de US $\$ 5,5$ bilhões.

Gráfico 8 - Comércio total e Saldo do comércio Brasil-África 2003-2010, em US\$ bilhões

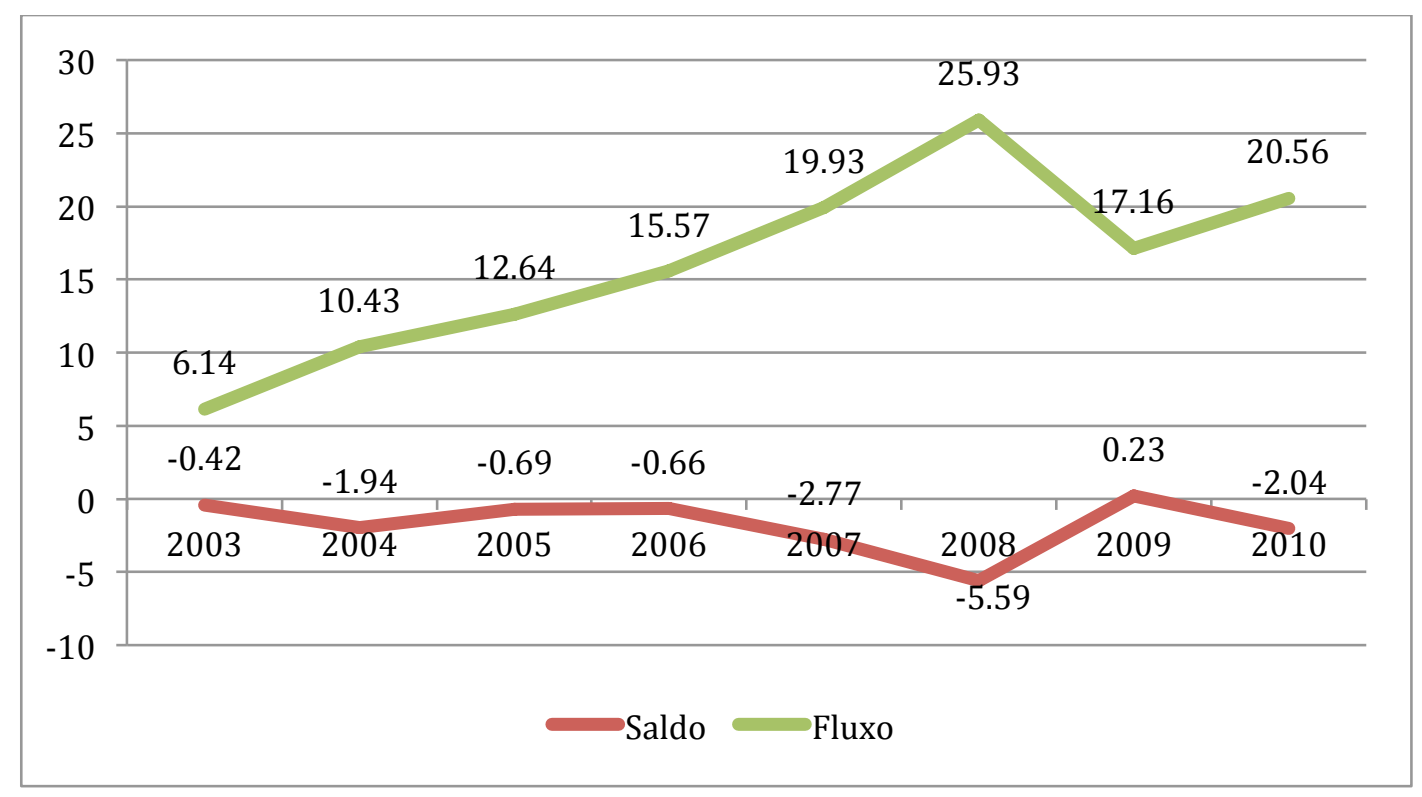

Fonte: Elaboração a partir de dados da Secex/MDIC.

\footnotetext{
${ }^{318}$ Ribeiro, Cláudio Oliveira. Relações Político Comerciais Brasil África (1985-2006). Tese de Doutorado FFLCH-USP, 2007, p. 187.

${ }^{319}$ Conforme consultado em aliweb.mdic.gov.br.
} 
A comparação entre a participação da África e de outros blocos ou países no intercâmbio total brasileiro, permite uma noção melhor do papel do continente africano nas relações com o Brasil. No gráfico abaixo foram colocadas lado a lado a evolução da participação nas exportações brasileiras da União Europeia, EUA, América Latina, China e África. A participação da União Europeia tem leve queda, enquanto a dos Estados Unidos têm uma visível queda de participação no período. China e América Latina ${ }^{320}$ fazem o movimento contrário, com a América Latina tendo um crescimento menos acentuado que o da China, que quase triplicou. A África, por sua vez, tem um pequeno aumento até 2007, quando mostra leve diminuição.

Gráfico 9 - Participação (\%) na exportações brasileiras por blocos, 2003-2010

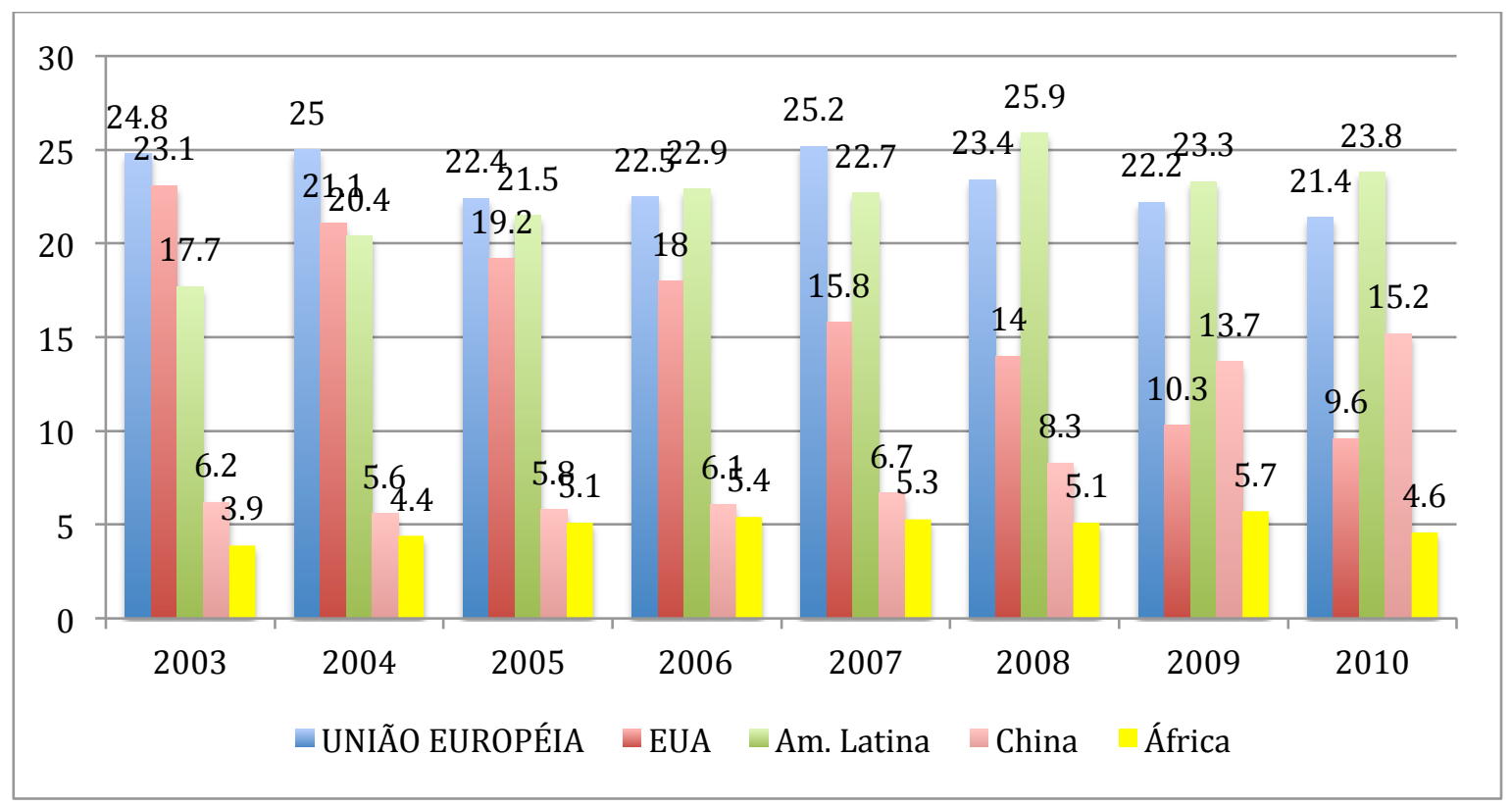

Fonte: Elaboração a partir de dados da Secex/MDIC. Em US\$1.000.

Já o quadro da participação na importações brasileiras desses mesmo blocos apresenta dados diferentes. Tanto a participação europeia quanto americana mostram pequeno decréscimo, enquanto a participação da América Latina mantém-se estável, e, por outro lado, as participações chinesas e africanas tem aumentos significativos. A participação africana diminui um pouco a partir de 2009, já como reflexo da crise.

\footnotetext{
${ }^{320}$ Os dados foram retirados das publicações da SECEX. América Latina inclui Caribe a partir de 2007.
} 
Gráfico 10 - Participação (\%) na importações brasileiras por blocos, 2003-2010

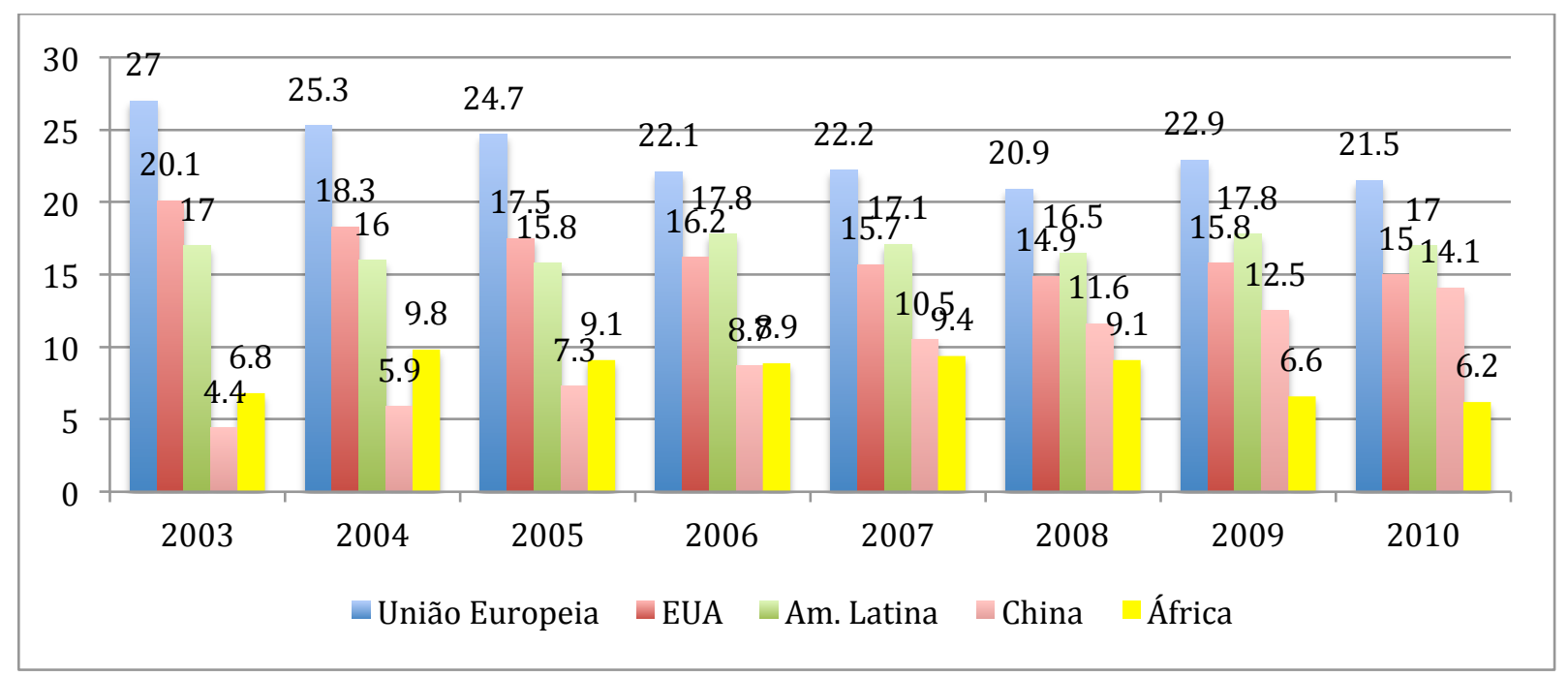

Fonte: Elaboração a partir de dados da Secex/MDIC. Em US\$1.000.

O auge do intercâmbio com o continente africano no período ocorreu em 2008, no patamar de US\$25,932 bilhões, para, na sequência da crise financeira mundial, diminuir e em seguida iniciar uma leve retomada. Observa-se, assim, que dentre os principais parceiros comerciais brasileiros, a África ainda encontra-se abaixo dos principais fluxos comerciais, o que não deve ser interpretado como algo irrelevante. $O$ crescimento do intercâmbio era notável até o momento da crise de 2008, como é possível observar no gráfico abaixo contendo apenas o comércio entre Brasil e África. Além disso, África e América do Sul juntos representam mais de $20 \%$ do comércio brasileiro, elemento nada irrelevante, tendo em vista o conjunto das relações comerciais brasileiras.

Gráfico 11 - Intercâmbio comercial Brasil-África, 2003-2010

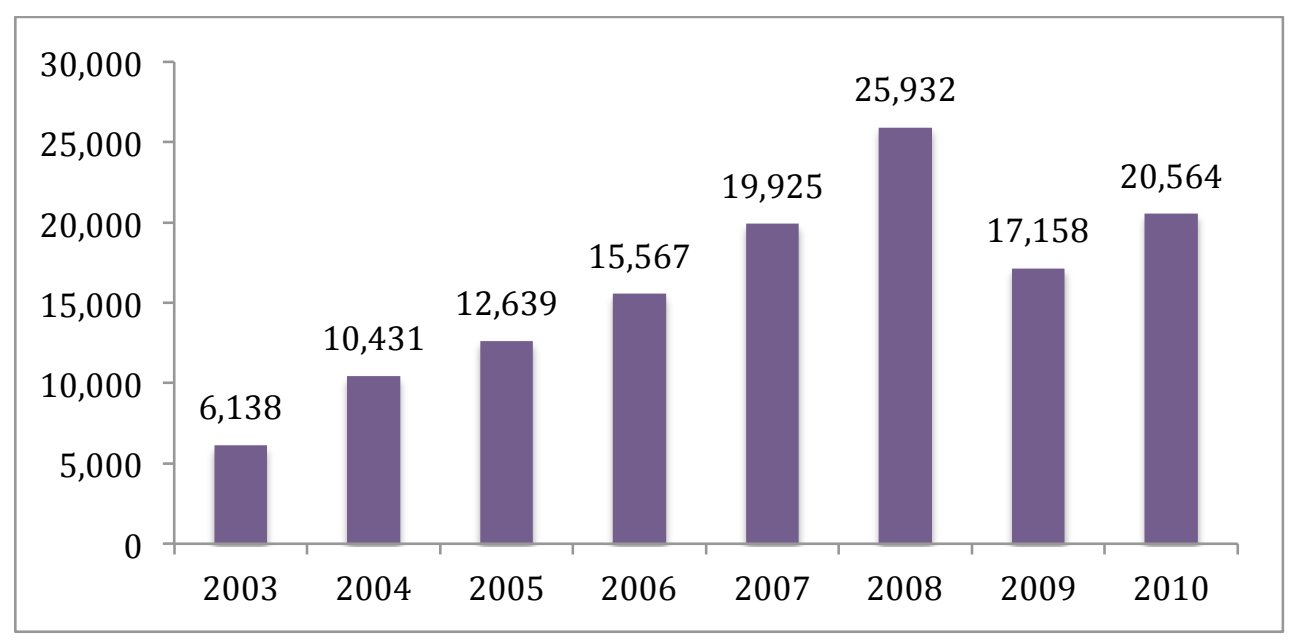

Fonte: Elaboração a partir de dados da Secex/MDIC. Em US\$1.000. 
O saldo é deficitário pela característica da pauta de importações brasileiras, concentrada em combustíveis e adubos, enquanto o forte das exportações para o continente africano são açúcar, carnes e cereais, com uma participação de máquinas, como veremos mais adiante. Outra observação interessante é o peso da África do Norte no fluxo comercial, considerando que Argélia, Líbia e Egito são importantes fornecedores de petróleo, além de Marrocos e Tunísia.

Os principais países africanos compradores do Brasil no período são invariavelmente África do Sul, Nigéria, Egito, Angola, Argélia e Marrocos. Já os principais países vendedores são Nigéria, Argélia, Marrocos e África do Sul, com o destaque para Líbia e Angola no segundo mandato do presidente Lula. Analisando a tabela abaixo, de participação em cada corrente comercial, com o porcentual dos principais parceiros, podemos verificar melhor a grande participação de países do norte da África na composição dos fluxos comerciais. Nigéria e Argélia são os principais fornecedores africanos de combustíveis para o Brasil, enquanto o Marrocos é produtor e fornecedor de adubos. A África do Sul, no período, foi a maior compradora de produtos brasileiros, comprando principalmente carnes, automóveis e autopeças.

Tabela 12 - Participação (\%) dos principais parceiros na balança com a África 2003-2010

\begin{tabular}{|c|c|c|c|c|c|c|c|c|}
\hline \multicolumn{9}{|c|}{ Participação na Exportação } \\
\hline & 2003 & 2004 & 2005 & 2006 & 2007 & 2008 & 2009 & 2010 \\
\hline África do Sul & 25.6 & 24.4 & 22.9 & 19.6 & 20.5 & 17.3 & 14.5 & 14.1 \\
\hline Nigéria & 16.4 & 11.9 & 15.9 & 18.4 & 17.6 & 15.1 & 12.3 & 9.3 \\
\hline Egito & 16.1 & 14.7 & 14.5 & 18.1 & 14.4 & 13.9 & 16.6 & 21.2 \\
\hline Angola & 8.2 & 8.4 & 8.7 & 11.2 & 14.2 & 19.4 & 15.3 & 10.2 \\
\hline Marrocos & 7.9 & 8.2 & 6.9 & 5.3 & 5.1 & 5.0 & 6.2 & 7.6 \\
\hline Argélia & 5.4 & 8.2 & 6.4 & 6.1 & 5.8 & 6.2 & 8.2 & 9.1 \\
\hline \multicolumn{9}{|c|}{ Participação na Importação } \\
\hline Nigéria & 46.2 & 56.6 & 39.7 & 48.3 & 46.5 & 42.5 & 56.2 & 52.4 \\
\hline Argélia & 34.1 & 31.4 & 42.5 & 24.3 & 19.7 & 15.9 & 16.3 & 20.9 \\
\hline África do Sul & 6.1 & 4.3 & 5.1 & 5.4 & 4.6 & 4.9 & 5.1 & 6.7 \\
\hline Marrocos & 6.1 & 3.9 & 4.7 & 4.1 & 4.7 & 7.3 & 4.0 & 5.9 \\
\hline Líbia & 0.8 & 0.9 & 0.5 & 3.6 & 8.8 & 8.9 & 9.9 & 0.9 \\
\hline Angola & 0.2 & 0.1 & 0.0 & 5.7 & 8.3 & 14.2 & 1.6 & 4.4 \\
\hline
\end{tabular}

Fonte: Elaboração a partir de dados da Secex/MDIC.

Desse modo, a África do Norte é uma região importante no intercâmbio comercial com o Brasil, tanto na exportação quanto na importação. A tabela abaixo, montada a partir da 
participação de cada região no comércio brasileira, fornece mais elementos para verificar o peso de cada região. No lado da exportação, as regiões do norte, sul e oeste são aquelas que mais compram produtos brasileiros, considerando que os maiores parceiros comerciais estão nessas regiões, como África do Sul, Nigéria e Argélia. No período, a África Austral perdeu espaço justamente para a África do Norte na pauta de exportação, assim como a Ocidental, apesar de menos acentuada. A Central e Oriental não representam nem 10\% da pauta, mas ambos cresceram no período. Já na importação, a corrente se concentra na África do norte e ocidental, origem dos principais fornecedores de petróleo no continente ao Brasil. No período analisado, é interessante notar que houve uma gradual diminuição da presença da região na pauta, refletindo a diversificação de fornecedores de petróleo pelo continente e a concentração do fornecimento na Nigéria, que puxa a participação da região ocidental na pauta de importação. A África Central aumentou a participação na importação, apesar de ainda baixa, e a África Oriental apresenta participação quase nula como mercado fornecedor.

Tabela 13 - Participação (\%) no comércio brasileiro para África, por região ${ }^{321}$

\begin{tabular}{|l|l|l|l|l|l|l|}
\hline Exportação & \multicolumn{5}{|l|}{} \\
\hline & CPLP & Afr. Central & Afr. Oriental & Afr. Norte & Afr. Austral & Afr. Ocidental \\
\hline 2003 & 9.67 & 1.20 & 2.14 & 34.16 & 35.30 & 26.84 \\
\hline 2004 & 10.09 & 1.28 & 2.59 & 37.64 & 34.22 & 22.75 \\
\hline 2005 & 11.12 & 1.51 & 3.17 & 34.11 & 32.68 & 27.14 \\
\hline 2006 & 13.58 & 1.29 & 2.70 & 35.23 & 31.80 & 27.59 \\
\hline 2007 & 16.41 & 1.97 & 1.84 & 31.65 & 35.49 & 28.77 \\
\hline 2008 & 20.34 & 3.55 & 1.53 & 31.92 & 37.76 & 24.82 \\
\hline 2009 & 17.28 & 3.59 & 3.32 & 36.52 & 32.16 & 23.04 \\
\hline 2010 & 11.23 & 3.23 & 4.02 & 46.95 & 25.50 & 19.81 \\
\hline Importação & & & & & & \\
\hline & CPLP & Afr. Central & Afr. Oriental & Afr. Norte & Afr. Austral & Afr. Ocidental \\
\hline 2003 & 0.39 & 1.95 & 0.00 & 43.40 & 6.76 & 47.77 \\
\hline 2004 & 0.09 & 0.25 & 0.01 & 38.11 & 4.63 & 57.19 \\
\hline
\end{tabular}

${ }^{321}$ CPLP composta de Angola, Moçambique, Guiné-Bissau, Cabo Verde e São Tomé e Príncipe; África Central: Rep. Centro Africana, Camarões, Rep. Congo, Congo, Gabão, Guiné Equatorial, S. Tomé e Príncipe, Chad; África Oriental: Burundi, Djibouti, Eritreia, Etiópia, Quênia, Ruanda, Somália, Tanzânia, Uganda; África do Norte: Argélia, Egito, Líbia, Marrocos, Mauritânia, Tunísia; África Austral: Angola, Botsuana, Lesotho, Moçambique, Malaui, Namíbia, Suazilândia, África do Sul, Zâmbia, Zimbábue; África Ocidental: Benin, Burkina Faso, Costa do Marfim, Cabo Verde, Gana, Guiné, Guiné-Bissau, Gâmbia, Libéria, Mali, Níger, Nigéria, Senegal, Serra Leoa, Togo. 


\begin{tabular}{|l|l|l|l|l|l|l|}
2005 & 0.02 & 5.61 & 0.01 & 51.33 & 5.63 & 41.97 \\
\hline 2006 & 5.84 & 6.46 & 0.02 & 33.99 & 11.37 & 49.28 \\
\hline 2007 & 8.61 & 4.69 & 0.04 & 35.33 & 13.33 & 48.48 \\
\hline 2008 & 14.56 & 2.46 & 0.04 & 35.60 & 19.62 & 44.64 \\
\hline 2009 & 1.71 & 3.26 & 0.03 & 33.49 & 7.12 & 59.22 \\
\hline 2010 & 4.66 & 5.56 & 0.01 & 31.71 & 11.83 & 55.59 \\
\hline
\end{tabular}

Fonte: Comtrade/Unctad. World Integrated Trade Solution (Wits)

Nesta tabela podemos ver também a participação dos países africanos de língua oficial portuguesa (PALOP), membros da Comunidade dos Países de Língua Portuguesa (CPLP) ${ }^{322}$. Como esse grupo tem especial atenção dentro da política externa africana do Brasil, é interessante separar as análises das relações comerciais do Brasil. Na exportação, o grupo tem presença na pauta brasileira, com destaque para o ano de 2008, apresentando queda posteriormente. Quanto à importação, teve um crescimento a partir de 2006, chegando ao pico de $14 \%$ em 2008, e também apresentando queda posteriormente. Analisando individualmente os países dentro do bloco, observamos que os valores são puxados pela presença de Angola no grupo, que é um dos principais parceiros individuais brasileiros no comércio. Moçambique e Cabo Verde tem um aumento significativo no fluxo comercial, na comparação entre os períodos correspondentes aos mandatos do presidente Lula. As exportações do Brasil ao bloco tiveram significativo aumento no segundo mandato. Os produtos exportados seguem as linhas gerais das exportações brasileiras para a África, ou seja, se concentram em açúcar, automóveis de transporte e carnes. As importações brasileiras do bloco são puxadas pelo fornecimento de petróleo de Angola, seguido de algodão de Moçambique.

Tabela 14 - Participação (\%) na Exportação e Importação brasileiros - CPLP/PALOPs

\begin{tabular}{|c|c|c|c|c|c|}
\hline \multicolumn{7}{|c|}{ Exportações } \\
\hline & Valor & Part. & & Valor & Part. \\
\hline & 1.951 .725 .596 & 91.4 & Angola & 5.472 .939 .137 & 93.2 \\
\hline Angola & 97.561 .144 & 4.6 & Moçambique & 208.183 .414 & 3.5 \\
\hline Moçambique & 77.859 .387 & 3.6 & Cabo Verde & 132.559 .585 & 2.3 \\
\hline Cabo Verde & 5.359 .010 & 0.3 & Guiné Bissau & 45.91 .646 & 0.8 \\
\hline Guiné Bissau & 2.150 .818 & 0.1 & São Tomé e Príncipe & 10.031 .100 & 0.2 \\
\hline São Tomé e Príncipe & 2.134 .655 .955 & & & 5.869 .304 .882 & \\
\hline total & & & & &
\end{tabular}

${ }^{322}$ A Guiné Equatorial é atualmente membro da CPLP, porém seu ingresso ocorreu após o período analisado, em 2012. 


\begin{tabular}{|c|c|c|c|c|c|}
\multicolumn{7}{|c|}{ Importações } \\
\hline Angola & 470.752 .276 & 99.0 & Angola & 5.774 .411 .360 & 96.0 \\
\hline Moçambique & 4.203 .134 & 0.9 & Moçambique & 228.277 .816 & 3.8 \\
\hline São Tomé e Príncipe & 651.250 & 0.1 & Cabo Verde & 10.185 .422 & 0.2 \\
\hline Cabo Verde & 91.228 & 0.0 & Guiné Bissau & 2.140 .091 & 0.0 \\
\hline Guiné Bissau & 1.440 & 0.0 & São Tomé e Príncipe & 8.067 & 0.0 \\
\hline total & 475.699 .328 & & & 6.015 .022 .756 & \\
\hline
\end{tabular}

Fonte: Elaboração a partir de dados do AliceWeb/Secex/MDIC. Em US\$.

Analisando especificamente os produtos comercializados, na exportação e importação, podemos verificar quais os são os principais e os países compradores e fornecedores. A tabela abaixo agregou os principais produtos no período do segundo mandato, considerando que a lista praticamente não difere dos produtos no primeiro mandato. Desse modo, a metade superior dos produtos são bens primários, principalmente açúcar, carnes bovinas e de aves, petróleo e minério de ferro. Já a metade inferior são produtos manufaturados, de capital, principalmente máquinas de construção e de transporte. Nenhum desses produtos chega ao montante de U\$S1,0 bilhão no período, cujo total corresponde a $10,85 \%$ da pauta de exportação no período, enquanto apenas o açúcar corresponde a 24,19\%. Motta Veiga enfatiza o peso dos produtos manufaturados de origem agropecuária na pauta de exportação, que no período representa cerca de $50 \%$ da exportação brasileira, diferenciando essa pauta bilateral da global brasileira ${ }^{323}$. Outros manufaturados, como os veículos, não chegariam a $20 \%$ da pauta.

Tabela 15 - Principais produtos exportados por países africanos do Brasil, 2007-2010

\begin{tabular}{|l|l|l|}
\hline Produto & Valor & Países \\
\hline $\begin{array}{l}\text { Açúcares de cana ou de } \\
\text { beterraba }\end{array}$ & 8.877 .456 .724 & $\begin{array}{l}\text { Nigéria, Argélia, Egito, Marrocos, } \\
\text { Gana, África do Sul, Angola }\end{array}$ \\
\hline Óleos de petróleo & 2.202 .515 .918 & $\begin{array}{l}\text { Nigéria, Angola, Gana, Quênia, Senegal, } \\
\text { Guiné Equatorial, Marrocos, África do Sul }\end{array}$ \\
\hline Carnes bovina congeladas & 2.088 .245 .999 & $\begin{array}{l}\text { Egito, Argélia, Líbia, Angola, Tunísia, } \\
\text { Guiné Eq. }\end{array}$ \\
\hline Carnes de aves & 1.943 .028 .570 & $\begin{array}{l}\text { África do Sul, Angola, Egito, Gana, Congo, } \\
\text { Benin }\end{array}$ \\
\hline Minérios de ferro & 1.887 .507 .336 & Egito, Líbia, África do Sul, Nigéria, Angola \\
\hline Óleo de soja & 916.732 .230 & $\begin{array}{l}\text { África do Sul, Argélia, Senegal, } \\
\text { Marrocos, Egito, Tunísia, Egito, Angola }\end{array}$ \\
\hline
\end{tabular}

${ }^{323}$ VEIGA, Pedro da Motta. A África na agenda econômica do Brasil: comércio, investimentos e cooperação. In RBCE, 116, 2013, p. 5-6. 


\begin{tabular}{|l|l|l|} 
Tratores & 871.433 .121 & $\begin{array}{l}\text { África do Sul, Angola, Marrocos, } \\
\text { Quênia, Nigéria, Moçambique }\end{array}$ \\
\hline $\begin{array}{l}\text { Veículos de transporte de } \\
\text { mercadorias }\end{array}$ & 854.440 .111 & $\begin{array}{l}\text { África do Sul, Angola, Nigéria, Marrocos, } \\
\text { Guiné Eq. }\end{array}$ \\
\hline Outros veículos aéreos & 726.236 .054 & $\begin{array}{l}\text { Egito, Líbia, Nigéria, Moçambique, Quênia, } \\
\text { Angola }\end{array}$ \\
\hline $\begin{array}{l}\text { Partes e acessórios de } \\
\text { veículos }\end{array}$ & 593.031 .634 & $\begin{array}{l}\text { África do Sul, Angola, Egito, Nigéria, Líbia, } \\
\text { Guiné Eq. }\end{array}$ \\
\hline Chassis, com motor & 532.068 .784 & $\begin{array}{l}\text { África do Sul, Egito, Angola, Quênia, } \\
\text { Tunísia, Nigéria }\end{array}$ \\
\hline Bulldozers & 404.077 .329 & $\begin{array}{l}\text { Angola, África do Sul, Etiópia, Argélia, } \\
\text { Nigéria }\end{array}$ \\
\hline
\end{tabular}

Fonte: Elaboração a partir de dados do AliceWeb/Secex/MDIC. Em US\$. Produtos pesquisados com nível de desagregação de 4 dígitos (SH4)

Já nos principais produtos importados pelo Brasil, conforme a tabela abaixo, a concentração da pauta ocorre em torno de combustíveis, adubos e fertilizantes. Apenas os 3 primeiros itens, relativos a petróleo, já dão conta de $85 \%$ do total das importações no período, enquanto os itens seguintes não chegam a $8 \%$. Os principais fornecedores de adubos estão na África do Norte, como Marrocos, Tunísia e Egito. Os principais fornecedores de produtos de petróleo são Nigéria, Argélia e Angola. A balança comercial é deficitária com todos os países fornecedores de petróleo, com a exceção de Angola, como aponta Paulo Cordeiro ${ }^{324}$.

Tabela 16 - Principais produtos importados para o Brasil, por países, 2007-2010

\begin{tabular}{|l|l|l|}
\hline Produto & Valor & Países \\
\hline Óleos brutos de petróleo & 34.572 .228 .030 & $\begin{array}{l}\text { Nigéria, Argélia, Angola, } \\
\text { Líbia, Guiné Eq. }\end{array}$ \\
\hline Óleos de petróleo & 3.976 .388 .055 & $\begin{array}{l}\text { Argélia, Nigéria, Marrocos, } \\
\text { Líbia, Egito, Angola, África } \\
\text { do Sul }\end{array}$ \\
\hline $\begin{array}{l}\text { Gás de petróleo } \\
\text { Adubos (fertilizantes) minerais ou } \\
\text { químicos }\end{array}$ & 1.445 .150 .941 & $\begin{array}{l}\text { Argélia, Nigéria, Angola, } \\
\text { Guiné Eq. }\end{array}$ \\
\hline $\begin{array}{l}\text { Adubos (fertilizantes) minerais ou } \\
\text { químicos, fosfatados }\end{array}$ & 891.790 .429 & $\begin{array}{l}\text { Marrocos, Tunísia, África } \\
\text { do Sul, Senegal, Egito, } \\
\text { Angola, África do Sul }\end{array}$ \\
\hline Fosfatos de cálcio e aluminocálcicos & 571.268 .523 & $\begin{array}{l}\text { Marrocos, Tunísia, Egito, } \\
\text { Senegal }\end{array}$ \\
\hline Pentóxido de difosfóro; ácido fosfórico; & 495.115 .581 & Marrocos, Argélia, Togo, \\
\hline
\end{tabular}

\footnotetext{
${ }^{324}$ PINTO, Paulo Cordeiro de Andrade. Brasil África: relações privilegiadas In: RBCE 116 p. 60-61.
} 


\begin{tabular}{|l|l|l|} 
ácidos polifosfóricos & & \\
\hline Ferro-ligas & 281.497 .373 & $\begin{array}{l}\text { África do Sul, Zimbábue, } \\
\text { Zâmbia }\end{array}$ \\
\hline $\begin{array}{l}\text { Hulhas; briquetes, bolas e combustíveis } \\
\text { sólidos }\end{array}$ & 279.603 .614 & África do Sul, Seicheles \\
\hline
\end{tabular}

Fonte: Elaboração a partir de dados do AliceWeb/Secex/MDIC. Em US\$. Produtos pesquisados com nível de desagregação de 4 dígitos (SH4)

Ainda na análise dos produtos na pauta de comércio, a tabela abaixo mostra a participação da África e da África Subsaariana no comércio brasileiro, a partir de categorias de fator agregado. A participação maior, como já pudemos observar acima, está com a categoria de bens primários, com o peso maior quando incluída a África do Norte. A África Subsaariana tem participação mais relevante nas categorias de bens de capital e de consumo. A categoria de bens de capital, especificamente, fica atrás dos bens de consumo e os primários, apesar do aumento até 2008 e consequente queda em 2010. Lautenschlager, em estudo específico sobre a exportação de bens de capital para a África, aponta o que também pudemos ver aqui, da concentração das vendas para alguns países e alguns produtos. Além disso, também aponta que após 2009 as vendas não retomam o número atingido antes da crise. Entretanto, visto num aspecto mais amplo, a participação do Brasil nesses mesmos setores de bens de capital - especificamente aqueles constantes na pauta para a África - no comércio internacional como um todo é bem pequena, cerca de $0,6 \%$, menor do que o apresentado na África ${ }^{325}$.

Tabela 17 - Participação (\%) na exportação brasileira, por categoria

\begin{tabular}{|l|r|r|r|r|r|r|r|r|}
\hline Export. & \multicolumn{2}{|c|}{2003} & \multicolumn{2}{|c|}{2004} & \multicolumn{2}{|c|}{2005} & \multicolumn{2}{|c|}{2006} \\
\hline & África & Áfr. Subs. & África & Áfr. Subs. & África & Áfr. Subs. & África & Áfr. Subs. \\
\hline Capital & 3,91 & 3,27 & 4,09 & 3,36 & 4,76 & 3,81 & 5,32 & 4,34 \\
\hline Consumo & 6,01 & 4,48 & 6,25 & 4,58 & 7,58 & 5,83 & 8,02 & 6,61 \\
\hline Intermediários & 3,49 & 1,85 & 3,99 & 1,89 & 4,97 & 2,70 & 5,63 & 2,87 \\
\hline Primários & 2,83 & 1,02 & 3,91 & 1,34 & 3,82 & 1,24 & 3,70 & 1,02 \\
\hline Total & 3,89 & 2,45 & 4,37 & 2,57 & 5,03 & 3,12 & 5,39 & 3,35 \\
\hline & \multicolumn{2}{|r|}{2007} & & 2008 & & 2009 & \multicolumn{2}{|c|}{2010} \\
\hline & África & Áfr. Subs. & África & Áfr. Subs. & África & Áfr. Subs. & África & Áfr. Subs. \\
\hline Capital & 6,37 & 5,13 & 6,70 & 5,66 & 7,88 & 6,01 & 5,17 & 4,01 \\
\hline
\end{tabular}

325 LAUTENSCHLAGER, Alexandre e CATERMOL, Fabrício. A participação das exportações brasileiras no comércio mundial de bens de capital para a África. In. BNDES Setorial n. 34, 2001, p. 301-302. 


\begin{tabular}{|l|r|r|r|r|r|r|r|r|} 
Consumo & 8,85 & 7,59 & 9,33 & 8,02 & 9,04 & 7,67 & 7,48 & 6,11 \\
\hline Intermediários & 4,95 & 2,60 & 4,62 & 2,37 & 5,72 & 2,70 & 4,99 & 1,75 \\
\hline Primários & 3,12 & 1,12 & 2,98 & 0,99 & 3,40 & 1,20 & 3,24 & 0,94 \\
\hline Total & 5,31 & 3,55 & 5,11 & 3,39 & 5,63 & 3,42 & 4,63 & 2,37 \\
\hline
\end{tabular}

Fonte: Comtrade/Unctad. World Integrated Trade Solution (Wits). Categorias conforme sistematização do HS 1988/92

Quanto ao comércio especificamente de petróleo, a tabela abaixo apresenta os principais fornecedores ao Brasil, separados nos dois períodos da administração Lula. O que se nota é a diminuição da Argélia na participação total de fornecimento para o Brasil, enquanto a Nigéria se mantém como principal centro fornecedor. Entre um período e outro, nota-se também o crescimento da participação de Angola, Líbia e Guiné Equatorial, demonstrando certa diversificação de fornecedores, apesar da concentração na Nigéria. Para Motta Veiga, isso seria um reflexo da política externa brasileira, com o estreitamente de laços, principalmente, com Líbia e Guiné Equatorial ${ }^{326}$.

Tabela 18 - Principais fornecedores de petróleo e participação no comércio brasileiro

\begin{tabular}{|c|c|c|c|c|c|}
\hline \multicolumn{3}{|l|}{$2003-2006$} & \multicolumn{3}{|l|}{$2007-2010$} \\
\hline & Valor & Part. & & Valor & Part. \\
\hline Nigéria & 11.220 .984 .870 & 41.1 & Nigéria & 21.985 .220 .518 & 45.9 \\
\hline Argélia & 6.453 .473 .936 & 23.6 & Argélia & 4.365 .512 .153 & 9.1 \\
\hline Congo & 408.964 .022 & 1.5 & Líbia & 3.177 .508 .409 & 6.6 \\
\hline Guiné Eq. & 397.098 .210 & 1.5 & Angola & 3.453 .007 .509 & 7.2 \\
\hline Líbia & 175.939 .633 & 0.6 & Guiné Eq. & 1.221 .336 .667 & 2.6 \\
\hline $\begin{array}{l}\text { Rep. Dem. } \\
\text { Congo }\end{array}$ & 127.668 .946 & 0.5 & Rep. Dem. Congo & 173.337 .009 & 0.4 \\
\hline & & & Congo & 134.918 .633 & 0.3 \\
\hline & & & Camarões & 61.387 .132 & 0.1 \\
\hline
\end{tabular}

Fonte: Elaboração a partir de dados do AliceWeb/Secex/MDIC. Em US\$. Código do Produto 2709 (SH4)

Ao fim dessa análise mais detalhada do intercâmbio comercial entre Brasil e África, podemos inicialmente afastar os argumentos mais extremos a favor e contra os impactos comerciais da política externa à África. Nos dois sentidos, o valor do comércio cresce em consonância com o aumento mundial. Não há um aumento do comércio com países africanos

${ }^{326}$ Veiga, op. cit., p. 6. 
em detrimento ao comércio com os tradicionais parceiros, como os Estados Unidos. Houve um grande aumento do comércio com a África no período, mas relativamente a outros parceiros, ela continua menor - o que não tira sua importância como mercado. A União Europeia manteve em grande medida a participação no fluxo comercial com o Brasil, apesar do recuo norte-americano, o que não significa que o fluxo foi redirecionado para África ou América Latina, considerando que a principal mudança foi a demanda chinesa.

Entretanto, não houve uma diversificação na pauta de exportação brasileira, concentrando-se ainda nos produtos manufaturados agrícolas e um leve aumento das exportações de veículos e peças - sendo a África um dos importantes destinos desses produtos brasileiros. No período, houve certa diversificação nos parceiros fornecedores de petróleo, mas não na pauta em si. Ainda assim, esse quadro está longe daquele das décadas anteriores, onde a concentração de parceiros e produtos era ainda maior - na década de 80, Argélia, Nigéria e Angola eram responsáveis por metade das exportações do Brasil e quase a totalidade das importações para o Brasil ${ }^{327}$.

A importância da África como mercado consumidor e fornecedor do Brasil vai além de números de participação; há o potencial futuro de garantir a África como consumidora das manufaturas brasileiras, tendo em vista o seu crescimento econômico na última década, e também manter os centros fornecedores de petróleo.

A crise financeira de 2008, porém, cortou o crescimento e impediu, nesse período, a manutenção e diversificação das exportações. A política comercial, em conjunto com a política externa do governo Lula, sem dúvida atuaram para incrementar as relações comerciais. O aumento das trocas com os PALOPs é um reflexo disso - e cabe lembrar que Guiné Equatorial tornou-se um membro da CPLP em 2012, resultado do estreitamento de relações. Por outro lado, o intercâmbio comercial com Moçambique é pequeno.

Por último, cabe notar as iniciativas para a celebração de acordos extrarregionais do Mercosul com o Egito e com a União Aduaneira da África Austral (SACU). O primeiro é um acordo de livre comércio, celebrado em 2010, visando incrementar o fluxo entre as parte, especialmente as exportações de alimentos produzidos no âmbito do Mercosul. O segundo é um acordo de preferências fixas, celebrado em 2008, tratando de mais de 1000 linhas tarifárias de cada parte ${ }^{328}$. Entretanto, tais acordos foram ratificados e internalizados apenas no fim de 2015, sendo que o atraso referente ao acordo com a SACU se deu com problemas

\footnotetext{
${ }^{327}$ OLIVEIRA, Henrique Altemani de. Política Externa Brasileira e Relações Comerciais Brasil-África. Tese FFLCH-USP, 1987, p. 303.

${ }^{328}$ Pinto, op. cit. p. 61 .
} 
de tradução do texto do acordo ${ }^{329}$.

\subsubsection{Sintese}

Ao observarmos as diferentes esferas da dimensão econômica, notamos que não há uma interação profunda entre as mesmas, ao contrário das esferas das dimensões política e cooperativa. O perdão de dívidas, como dito, tem relação tanto com a dimensão política quanto com a cooperativa, mas pelo aspecto econômico e por fazer parte de uma negociação mais ampla no contexto internacional, acreditamos que se ligue a esta dimensão. Além disso, guarda relação com a esfera comercial, pois a regularização das dívidas externas africanas com o Brasil possibilita a retomada de linhas de crédito e consequentemente o fluxo comercial.

A esfera de investimentos, por sua vez, teve crescimento a partir do segundo mandato de Lula, concentrando-se em áreas de infraestrutura e mineração, e nos países parceiros tradicionais, como Angola e Moçambique. Médias empresas chegaram a entrar no mercado africano, mas não tiveram continuidade. Os investimentos não mostraram nenhuma relação direta com as outras esferas econômicas, tendo, apesar disso, alguma proximidade com a dimensão política, na figura do presidente Lula, que estimulou pessoalmente o investimento brasileiro em suas viagens.

Já a esfera comercial teve grande destaque no período. Verificou-se o aumento do fluxo comercial, mas pouca expansão tanto da pauta quanto de parceiros. Ou seja, houve sim diversificação de produtos e novos parceiros, mas não na medida esperada. Não parece haver, também, alguma relação entre a abertura de embaixadas e aumento do comércio bilateral, sendo essa relação mais próxima com os projetos de cooperação. $\mathrm{O}$ aumento do comércio Brasil-África seguiu a tendência do aumento geral do fluxo comercial internacional, tanto que o grande aumento absoluto fica diluído na participação total do comércio brasileiro como um todo.

Ao fim, podemos observar que a dimensão econômica guarda menor relação com as outras dimensões e possui menor interrelação entre suas esferas. A dimensão política chega a estar presente aqui, principalmente pela figura do presidente Lula, mas o aspecto econômico se mostra muito mais independente do que as outras dimensões.

\footnotetext{
${ }^{329}$ Pareceres do Senado Federal n. 749 e 819 de 2015, respectivamente.
} 


\subsection{Síntese do governo Lula}

Após a análise das dimensões da política externa brasileira para África, como aqui proposta, podemos concluir que o continente africano teve realmente um espaço maior do que durante os governos anteriores. Em comparação com os períodos antecedentes, não houve exatamente uma mudança nas relações, mas sim um aprofundamento, na medida que a diplomacia buscou expandir as relações bilaterais no continente africano, não se concentrando apenas nas tradicionais parcerias, com Angola, África do Sul e Nigéria.

Entretanto, com a perspectiva das várias dimensões ao longo do período, podemos também notar algumas proximidades e distanciamentos entre os elementos. Em primeiro lugar, apontamos a participação intensa do Estado, por meio da diplomacia presidencial, no estímulo aos empresários e empreiteiras a fim de investirem no continente africano. $\mathrm{O}$ presidente Lula, e as embaixadas em certa medida, fazem um papel de canal de comunicação, tendo em vista o desconhecimento mútuo das partes. O investimento de empresas segue um crescimento contínuo durante o período, ao contrário dos investimentos das empreiteiras, que se concentram no segundo mandato.

Em segundo lugar, a esfera comercial, assim como a dimensão econômica como um todo, não parece ter uma forte conexão com outras dimensões e esferas. O intercâmbio comercial com a África, apesar do crescimento absoluto relevante durante o período, guarda mais relação com o próprio crescimento do comércio internacional, ou seja, de uma conjuntura favorável, que aumentou o comércio como um todo tanto do Brasil quanto de países africanos.

A dimensão cooperativa, apesar de não receber a mesma atenção que o aspecto econômico-comercial, nos parece ser a dimensão que mais cresceu no governo Lula, aproveitando-se de base já consolidada da experiência brasileira com cooperação para o desenvolvimento. A relação com a esfera bilateral de embaixadas é direta, apesar de que no período ainda não se note um aumento significativo de projetos em países com embaixadas recém-abertas, mas é aparente a construção de um canal de comunicações com países africanos com quem se tinha poucas informações. $\mathrm{O}$ aumento da cooperação se dá em meados para o fim do período, refletindo o aporte orçamentário e de pessoal da $\mathrm{ABC}$.

Elaboramos o quadro-síntese abaixo para ilustrar que as dimensões, apesar de estarem de alguma forma conectadas, elas não se encontram totalmente entrosadas. A dimensão econômica, como dito, não possui tanta conexão com as outras dimensões, em especial as esferas de investimento e comercial. A dimensão política se conecta com a cooperativa 
principalmente pelas esferas de visitas e de aberturas de embaixadas. $\mathrm{O}$ aspecto multilateral da dimensão política também ajuda no crescimento da dimensão cooperativa, e ao mesmo tempo recebe influência dessa dimensão, na medida que retorna como apoio político em fóruns internacionais. A dimensão política tem conexão com a econômica por meio da figura do presidente Lula, que, durante as suas visitas, estimula grupos de empresários a conhecer e investir nos países africanos, além de servir de ponte para financiamentos via BNDES para empreiteiras investirem em infraestrutura e mineração em países como Angola e Moçambique. A única relação entre as dimensões econômica e cooperativa pode ser considerada no perdão de dívidas, que, como dito, também é encarado como cooperação SulSul para o desenvolvimento.

Quadro-síntese das dimensões da política externa brasileira para África

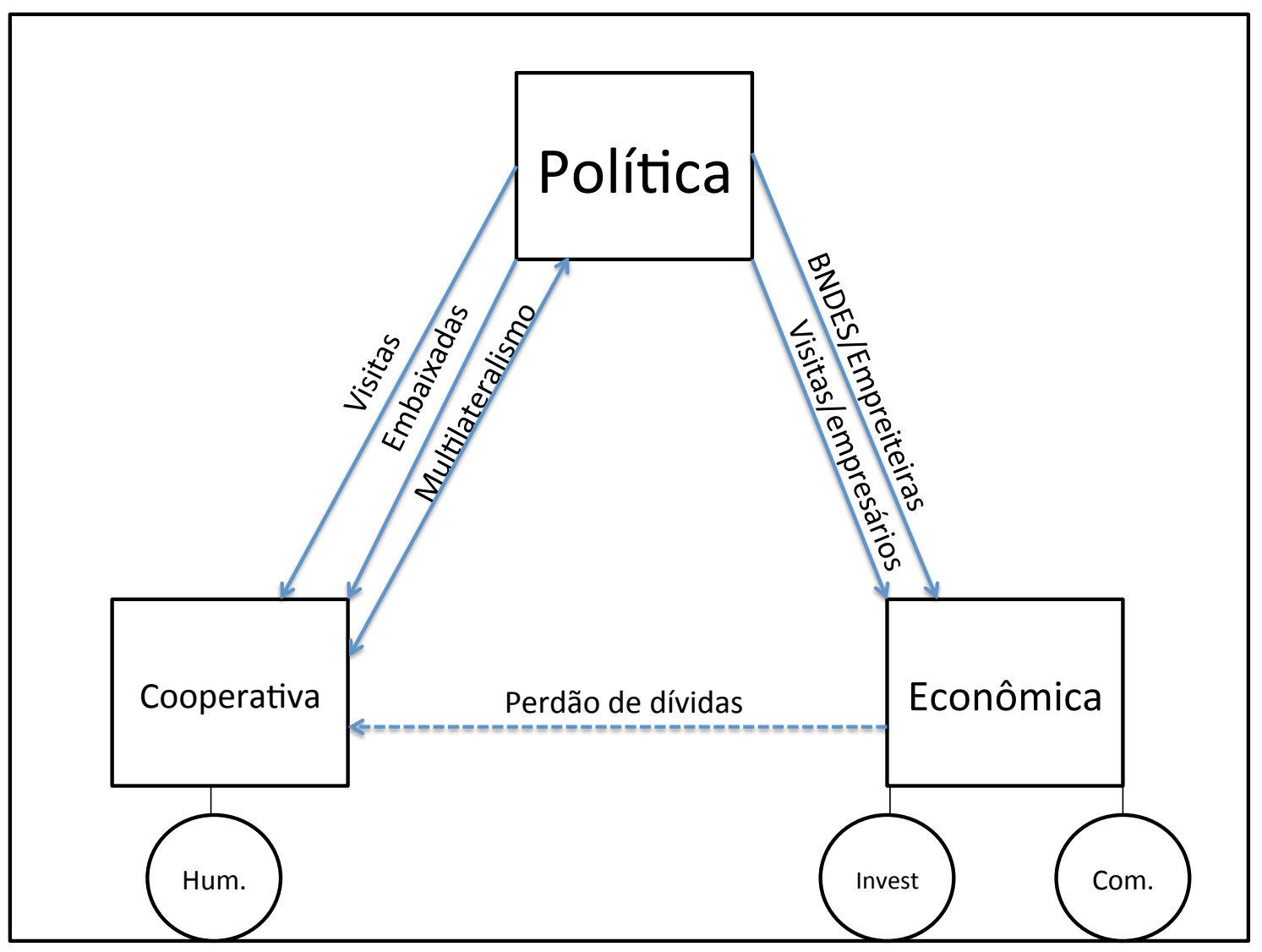




\section{Capítulo 3 - A Política EXterna Para a África nos disCursos e nOS DEbates}

Este capítulo abordará a dimensão retórica da política externa do período Lula no que condiz às relações Brasil-África, colocando também em perspectiva o debate que surge na grande mídia e nos meios acadêmicos sobre a relevância dessa política. Na parte retórica, utilizaremos discursos selecionados do então presidente Lula e de seu chanceler Celso Amorim que refletem as dimensões e esferas aqui já estudadas. Quanto aos debates, utilizaremos reportagens e editoriais da mídia impressa e artigos acadêmicos e de analistas de política externa. A seleção não foi exaustiva, buscando trazer, no caso dos discursos, exemplos de diferentes anos, sempre relacionados a eventos com países africanos, a fim de observar uma hipotética evolução nos temas. Os artigos da grande mídia e de acadêmicos foram selecionados a fim de mostrar outras posições além das presentes nos discursos oficiais, apontando a argumentação utilizada.

O objetivo deste capítulo é duplo. Em primeiro lugar, busca-se verificar se há nos discursos oficiais do governo brasileiro em 2003-2010, uma relação com as outras dimensões - política, econômica, cooperativa - e se a retórica imprime coerência para a política externa. Nesse sentido, trata-se de avaliar se a retórica expressa essa coerência ou se constrói uma imagem idealizada do continente africano na política externa. Em segundo lugar, busca-se mostrar o outro lado do debate acerca das relações Brasil-África, ao longo do governo Lula, procurando apontar as linhas gerais da discussão acadêmica-intelectual sobre essas relações em particular e a política externa com ênfase nas relações Sul-Sul em geral. Para além das posições extremadas, de franca defesa ou crítica, percebemos posições intermediárias, mais interessadas em discutir as diferentes abordagens e diferenças entre Lula e Fernando Henrique.

\subsection{As relações Brasil-África na retórica de Lula e Amorim}

Tomei posse na Presidência do Brasil no dia primeiro de janeiro de 2003, e tomei a decisão de que o Brasil precisaria fazer uma inflexão na sua política internacional. O Brasil precisaria ter um olho para a América do Sul e a América Latina e, ao mesmo tempo, ter outro olho para o continente africano. $^{330}$

\footnotetext{
${ }^{330}$ SILVA, Luis Inácio Lula da. Discurso do Presidente da República, Luiz Inácio Lula da Silva, por ocasião da I Sessão Plenária da II Conferência de Intelectuais da África e da Diáspora, Salvador, Bahia, 12 de julho de 2006 In: MRE. Resenha de Política Exterior do Brasil, n. 99, 2006, p. 37.
} 
A dimensão retórica da política externa brasileira desse período mostra como o continente africano esteve presente nos discursos oficiais do governo. Apesar do discurso presidencial acima ter sido proferido em 2006, a correção de rumo em direção ao continente africano foi um movimento presente desde o início de seu mandato, em 2003. O chanceler do período, Celso Amorim, com quem Lula teve evidente sinergia durante os dois mandatos, confirma a escolha consciente de Lula em relação à África. Amorim lembra que antes da posse do presidente eleito, ele deveria entregar à equipe de Lula alguns parâmetros da política externa para o discurso presidencial. Como havia um limite de uma página, escolheu não mencionar a África, em favor de outros temas mais relevantes naquele momento. No entanto, em seu discurso Lula não deixa de mencionar e reafirmar os laços profundos que unem o Brasil e o continente africano. ${ }^{331}$ Também deve se lembrar que a formulação de política externa do presidente Lula seria também influenciada pelo professor Marco Aurélio Garcia, que fora coordenador da secretaria de relações internacionais do PT por 12 anos, participando da elaboração do programa de governo do PT desde 1994, e posteriormente assessor chefe da Assessoria Especial da Presidência da República.

O destaque dado à África aparece no programa de governo do PT, em 2002, como podemos ver abaixo, de modo mais geral ao continente, e mais específico à África do Sul e países lusófonos - os principais parceiros africanos do Brasil nas relações históricas, algo que não difere de momentos anteriores. A menção à África ocorre no mesmo ponto em que o programa declara um política universalista e multilateralista, explicitando o objetivo de buscar maior democracia nas relações internacionais - assunto que também estará presente em discursos nos quais a África é tema, como veremos a seguir. O documento é interessante por pontuar uma posição, mas devemos observar que o Brasil tinha uma política externa anterior com a qual havia concordância de visões, especialmente em relação à África do Sul e a África lusófona, o que não parece ser suficiente para apontar a existência de uma partidarização ou ideologização da política externa a partir de 2003.

19. O Brasil buscará estabelecer relações econômicas, políticas e culturais com todo o mundo. Uma relação equilibrada com os países que integram o Acordo de Livre Comércio da América do Norte (NAFTA), a União Europeia e o bloco asiático em torno do Japão permitirá contornar constrangimentos internacionais, diminuir a vulnerabilidade externa e criar condições mais favoráveis para a inserção ativa do País no mundo. Ao mesmo tempo, nosso governo conduzirá a aproximação com países de importância regional, como África do Sul, Índia, China e Rússia. Trata-se de

${ }^{331}$ AMORIM, Celso. Breves Narrativas Diplomáticas. São Paulo: Benvirá, 2013, p. 142. 
construir sólidas relações bilaterais e articular esforços a fim de democratizar as relações internacionais e os organismos multilaterais como a Organização das Nações Unidas (ONU), o Fundo Monetário Internacional (FMI), a Organização Mundial do Comércio (OMC) e o Banco Mundial. O Brasil, como segundo país com maior população negra no mundo, deverá voltar-se para a África, explorando os laços étnicos e culturais existentes e construindo relações econômicas e comerciais. Com a África do Sul, em particular, buscará aproximação para construir nova política em direção àquele Continente, sobretudo no que se relaciona aos países de língua portuguesa. (grifos nossos) $)^{332}$

Um tema recorrente nos discursos de Lula em contextos africanos é o da dívida histórica do Brasil com a África, em virtude dos séculos de escravidão, o que significa para o historiador José Flávio Sombra Saraiva um rompimento com os discursos clássicos para a África, em especial na década de $1960^{333}$. Jânio Quadros, no entanto, como vimos no primeiro capítulo, também citava a "imensa dívida" do Brasil com o povo africano. O discurso culturalista, como aponta Saraiva, parte principalmente de Afonso Arinos, que via potencial num prestígio brasileiro na África no fato de ser um país de grande população negra, prestígio esse que poderia render apoio ao Brasil no cenário internacional. No entanto, Arinos seguia o raciocínio de que a miscigenação história teria transformado o Brasil numa democracia racial, senão a mais avançada do mundo ${ }^{334}$. Desse modo, tal tema, que se torna recorrente, muda ao não mais esconder ou relativizar a importância da escravidão para a História do Brasil, o que, segundo Saraiva, aproxima ainda mais a figura de Lula às lideranças africanas. Por exemplo, Lula, em jantar em homenagem ao presidente da África do Sul, afirma:

"O Brasil tem uma dívida com a África. Uma dívida de reconhecimento pela contribuição, em condições de sofrimento e opressão, que milhões de africanos deram para a construção do Brasil" ${ }^{\text {"33 }}$.

O tema da dívida histórica passa a ser também articulado tanto com os laços comuns advindos da escravidão, quanto com os problemas comuns que podem ser trabalhados em conjunto, em trocas de experiências, e principalmente com a cooperação brasileira. Além disso, a aproximação do Brasil com países africanos serviria para o fortalecimento mútuo no

\footnotetext{
332 PROGRAMA de Governo 2002 Coligação Lula Presidente, p. 7, http://novo.fpabramo.org.br/uploads/programagoverno.pdf

${ }^{333}$ SARAIVA, José Flávio Sombra. África Parceira do Brasil Atlântico: relações internacionais do Brasil e da África no início do século XXI. Belo Horizonte: Fino Traço, 2012, p. 110-112.

${ }^{334}$ FRANCO, Afonso Arinos de Melo. Planalto: Memórias. Rio de Janeiro: José Olympio, 1968, p. 63.

${ }^{335}$ SILVA, Luis Inácio Lula da. Discurso do Presidente em homenagem ao presidente da África do Sul, 08.11.2003. In: MRE. Resenha de Política Exterior do Brasil n. 93 2o sem 2003, p. 202.
} 
cenário internacional. O primeiro discurso de Lula em São Tomé e Príncipe apresenta todas essas características, além de ser a ocasião para a abertura oficial da embaixada brasileira na ilha.

Desta ilha partiram grandes contingentes de africanos escravizados, durante um dos capítulos mais sombrios da história da humanidade. Daqui, transferiram-se para o Nordeste brasileiro os primeiros engenhos de açúcar. Mas hoje nos reencontramos para celebrar os laços de amizade fraterna que nos unem. (...) Ao tomar posse como presidente, no início deste ano, determinei máxima prioridade ao aprofundamento de nossas relações com a África. Tenho repetido que isso constitui um dever moral e uma necessidade estratégica do Brasil. O imenso desafio de promover a inclusão e a equidade social nos aproxima. (...) Temos muito a aprender com a troca de experiências. Podemos desenvolver soluções inovadoras para problemas comuns. $\mathrm{O}$ combate à fome e à pobreza é tarefa inadiável. (...) Para isso, precisamos fortalecer nossa capacidade de articulação nos organismos internacionais. Devemos lutar para valorizar o multilateralismo, que está para as relações internacionais como a democracia para o plano nacional ${ }^{336}$.

As palavras de Celso Amorim seguem na mesma direção dos discursos do presidente. A retórica vai além do discurso diplomático-cultural de outrora, buscando um elemento africano na identidade brasileira, construída pelos séculos de escravidão, que deve basear as relações, estimulando uma atuação conjunta em relação a problemas comuns, tanto no aspecto interno quanto no sistema internacional. Amorim passa a colocar que os africanos buscam o Brasil, que há uma demanda africana (“fome de Brasil”) pela presença brasileira. Amorim traz essa ideia já em 2003, em entrevista à Agência Brasil e Rádios africanas:

O que move esse despertar de interesses? (Amorim): é uma busca da própria identidade do Brasil. (...) é interessante notar as semelhanças com o Brasil na maneira de ser, de falar, na música. Eu senti por todos os países pelos quais passei na África, não só nos de língua portuguesa, que existe uma fome de Brasil. (...) Eles têm de aprender muito, como nós também. Mas já passamos por um trajeto mais longo e temos muito a ensinar e também muito o que ganhar. (...) Existe uma oportunidade de cooperação econômica que será mutuamente proveitosa e ajudará a África a se desenvolver. $^{337}$

As dimensões econômicas, comerciais, geopolíticas e cooperativas vão aparecendo no

\footnotetext{
${ }^{336}$ Idem. Discurso do presidente Luiz Inácio Lula da Silva em São Tomé e Príncipe, 02.11.2003. In: MRE. Resenha de Política Exterior do Brasil n 93 2o sem 2003, p. 185-186.

${ }^{337}$ AMORIM, Celso. Para Amorim, Brasil vai redescobrir a África. Entrevista a Agência Brasil, 01.10.2003. In: MRE. Resenha de Política Exterior do Brasil n 93 2o sem 2003, p. 464.
} 
discurso oficial, frequentemente ao lado da ideia dos laços profundos e da dívida histórica, e da noção de benefício mútuo. O Fórum IBAS, ainda chamado de G-3, já seria mencionado pelo presidente como aprofundamento da coordenação entre os países. No trecho do discurso abaixo, feito durante visita à África do Sul, Lula coloca o país como parceiro estratégico do Brasil, e, como pudemos ver ao analisarmos a esfera multilateral no capítulo 2, a prática refletiu o discurso, com a consolidação da coalizão ao longo do período.

O Brasil quer uma relação estratégica com a África do Sul, com os países em desenvolvimento, com toda a África e com a América do Sul. (...) Mais ainda: o Brasil quer uma relação de parceria. Não queremos hegemonia, em nenhuma hipótese ${ }^{338}$. (...) Temos a convicção de que estamos construindo uma parceria estratégica. Uma parceira que vem amadurecendo de forma notável. Temos intensificado a cooperação nas mais diversas áreas, e são excelentes as perspectivas de ampliá-la ainda mais. Estamos levando essa coordenação a um novo patamar, com a fundação, em Brasília, do Fórum de Diálogo Índia, Brasil e África do Sul - o G- $3^{339}$.

Ao longo dos anos, outros temas caros à diplomacia brasileira - e defendidos pela política externa do governo Lula - seriam incorporados à retórica no contexto de encontros com países africanos - como a reforma do Conselho de Segurança da ONU, o multilateralismo e ordem internacional justa. $\mathrm{Na}$ primeira visita de Lula à Moçambique, em novembro de 2003, esses temas já são ensaiados:

"Essa relação que o Brasil pretende manter com os países da África não é uma relação de um país imperialista com vocação de hegemonia. (...) Queremos agora parceria, queremos companheirismo, queremos trabalhar de braços juntos para a construção de uma política internacional equânime, para organismos multilaterais, democráticos e para que tenhamos igualdade de oportunidades." 340

Nesse mesmo momento, a dimensão econômica também se faz presente, na menção ao perdão de dívidas a Moçambique e na referência direta aos empresários para investirem nos países africanos - lembrando que a comitiva da primeira viagem de Lula contou com dezenas de empresários brasileiros. O perdão de dívidas, como já analisado, pode ser encarado tanto do ponto de vista da dimensão cooperativa como da esfera comercial, pois, na prática, permite

\footnotetext{
${ }^{338}$ SILVA, Luis Inácio Lula da. Conferência Conjunta de Imprensa, Pretória, 08.11.2003. In: MRE, Resenha de Política Exterior do Brasil n 93 2o sem 2003, p. 201.

${ }^{339}$ Ibid., p. 202.

${ }^{340}$ SILVA, Luis Inácio Lula da. Discurso no jantar oferecido pelo presidente de Moçambique, Maputo, 05.11.2003, In: Resenha de Política Exterior do Brasil n 93 2o sem 2003, p. 192.
} 
a retomada de linhas de financiamento; mas encontra também peso considerável na dimensão retórica. Como analisado no capítulo anterior, o perdão de dívidas não é um processo rápido, não dependendo apenas da vontade do chefe de governo. No caso específico de Moçambique, a negociação do montante da dívida com o Brasil já ocorria desde antes do governo Lula, o que não impediu o presidente de explicitar a medida quando foi implementada, principalmente nos discursos, como o abaixo.

"Bem sabemos como o endividamento externo pode representar um peso insuportável para o desenvolvimento de um país. Por esta razão, o Brasil decidiu perdoar grande parcela da dívida de Moçambique conosco. Estamos certos de que, além de um gesto de solidariedade para com um povo que vem lutando contra seguidas adversidade, trata-se de medida de sentido econômico prático. Sem o peso dessas obrigações, Moçambique poderá acelerar ainda mais seu crescimento e terá melhores condições para ampliar suas trocas com outros países, inclusive com o Brasil. Senhores empresários, os governos do Brasil e Moçambique estão criando as condições propícias para a expansão da relação econômica e comercial entre Moçambique e o Brasil. Para realizarmos essas perspectivas, é fundamental que as empresas trabalhem junto com o governo. Por isso, convido agora os senhores a, como se diz no Brasil, vestirem a camisa deste time: o da cooperação Brasil-Moçambique.",341

Já em 2004, em visita ao Gabão, o tom econômico é mantido. O perdão de dívidas aqui é colocado tanto como aproximação solidária entre países emergente quanto chave para a possível participação de empresas brasileiras nas obras públicas do país. Chama atenção o destaque que Lula dá à experiência brasileira em mineração e infraestrutura, já promovendo empresas brasileiras que representariam grande parte do investimento brasileiro na África, conforme já estudado.

O aprofundamento de nossas relações com a África, além de um dever moral, é necessidade estratégica. A ordem econômica mundial apresenta dificuldades e desafios que só poderão ser superados por meio da aproximação solidária dos países em desenvolvimento. (...) São muitos os campos em que podemos estabelecer parcerias, no melhor espírito da cooperação Sul-Sul. A experiência brasileira em mineração, construção de estradas em meio tropical e geração de energia elétrica pode ser útil para o Gabão. (...) A conclusão do acordo de renegociação da dívida gabonesa com o Brasil estimulará empresas brasileiras a participarem em obras públicas do

${ }^{341}$ Ibid., p. 195. 
Gabão. $^{342}$

No mesmo ano de 2004, na visita a Cabo Verde, a dimensão geopolítica das relações se sobressai no discurso de Lula na Assembleia Nacional cabo-verdiana. Após falar sobre o apoio brasileiro ao ingresso de Cabo Verde na OMC e versar sobre a busca conjunta de um sistema de comércio internacional mais justo, Lula agradece o apoio cabo-verdiano à intenção brasileira de reforma do Conselho de Segurança da ONU. A demanda histórica brasileira por um assento no Conselho de Segurança aparece de forma mais recorrente no período, o que seria inclusive alvo de críticas, por ser considerada uma campanha muito aberta. Mas na mesma medida que angaria apoio a esse projeto notadamente difícil, Lula acabaria estabelecendo apoio para eleições de outros órgãos, como aconteceria após seu governo, com a eleição de brasileiros na FAO e OMC, como já estudado antes.

"O Conselho de Segurança deve ser democratizado. (...) Precisamos da participação efetiva dos países em desenvolvimento para assegurar a paz e a segurança. Agradeço novamente o apoio de Cabo Verde à aspiração brasileira de ocupar um assento permanente no Conselho de Segurança. O Brasil está preparado para assumir mais essa parcela de responsabilidade. ${ }^{, 343}$

Além disso, na mesma ocasião, Lula faz duas menções que são importantes para a construção da imagem do Brasil perante os países africanos, contribuindo para a aproximação, e, conforme Saraiva, apresentam uma linha de reflexão mais consistente para o campo do desenvolvimento social e econômico, não limitando as relações somente à esfera econômica e comercial, por exemplo ${ }^{344}$. Lula, então, menciona o sucesso do Programa Fome Zero no Brasil e coloca o combate à fome como prioridade na construção de uma sociedade internacional mais justa. A segunda menção é sobre o primeiro projeto do Fundo IBAS para Guiné-Bissau, sobre agricultura sustentável. Desse modo, o Fórum IBAS aparece como uma plataforma de cooperação, em sintonia com o discurso, na qual o Brasil tem relevante participação.

Não podemos relegar ao segundo plano o flagelo da escassez e da

\footnotetext{
${ }^{342}$ SILVA, Luis Inácio Lula da. Discurso do Presidente, Libreville, 27.07.2004. In: MRE. Resenha de Política Exterior do Brasil, n. 95, 2o Sem. 2004, p. 54.

${ }^{343}$ Idem. Discurso do Presidente na Assembleia Nacional de Cabo Verde, 29.07.2004. In: MRE. Idem, Resenha de Política Exterior do Brasil, n. 95, 2o Sem. 2004, p. 61.

${ }^{344}$ SARAIVA, op. cit., 2012, p. 113.
} 
pobreza, que aflige mais de um bilhão de pessoas em todo o mundo. Não haverá estabilidade econômica internacional, nem proteção contra o terrorismo enquanto não atribuirmos prioridade à construção de uma ordem mundial mais justa e democrática. Com o Programa Fome Zero, conseguimos a maior mobilização de solidariedade nacional da história do Brasil. Mostramos ao país que a fome e a extrema pobreza têm rosto - mas também solução. (...) Brasil, Índia e África do Sul criaram um fundo para demonstrar que a obrigação moral, política e econômica de colaborar é de todos. Aprovamos um primeiro projeto, voltado para o desenvolvimento sustentável da agricultura e da pecuária em Guiné-Bissau ${ }^{345}$.

No ano seguinte, os mesmos temas são retomados na viagem realizada em Camarões. A campanha de Lula para a erradicação da fome e pobreza continua, vinculada com a defesa das medidas protecionistas e subsídios para os produtos agrícolas dos países ricos. Mais uma vez, aproveita para valorizar a atuação do Brasil, por meio do G-20, pela mudança na desigualdade no cenário internacional. O presidente aproveita a ocasião para oficializar a reabertura da embaixada em Iaundê, um ato de reconhecimento frente ao aumento das relações bilaterais. Agradece tanto a União Africana quanto Camarões pelo apoio às aspirações brasileiras ao assento no Conselho de Segurança, sem deixar de lembrar que o próprio continente africano não conta com membro permanente no órgão da ONU.

Camarões foi um dos países mais receptivos à nossa iniciativa de relançar as relações com a África. Em reconhecimento, decidimos reabrir nossa embaixada em Iaundê. Nossa decisão é uma aposta na reaproximação com o Camarões e com todo o Continente. Asseguro-lhe que, desta vez, o Brasil veio para ficar. A reativação da Embaixada consolida nossa cooperação. (...) Exploramos complementaridades para multiplicar nossas potencialidades. É o caso do programa de cooperação técnica sobre o cacau (...) Agradeço a acolhida de seu Governo às iniciativas que o Brasil avançou no Encontro de Líderes para uma Ação contra a Fome e a Pobreza, em Nova Iorque, setembro passado (...) Por meio do G-20, temos lutado para que os produtos agrícolas dos países em desenvolvimento sejam remunerados em níveis compatíveis com seu valor de mercado e com a dignidade de seus produtores. Só assim conseguiremos derrubar o muro que divide a Humanidade entre ricos e pobres $(\ldots)^{346}$

Na mesma ocasião, Lula menciona a posição da União Africana quanto à reforma do Conselho de Segurança. Esse comentário faz referência à posição comum africana -

\footnotetext{
${ }^{345}$ SILVA, Luis Inácio Lula da. Discurso do Presidente na Assembleia Nacional de Cabo Verde, 29.07.2004. In: MRE. Resenha de Política Exterior do Brasil, n. 95, 2o Sem. 2004, p. 59-60.

${ }^{346}$ SILVA, Luis Inácio Lula da. Discurso do Presidente para o presidente de Camarões, 10.04.2005. In: MRE. Resenha de Política Exterior do Brasil, n. 96, 2005, p. 95-96.
} 
conhecida como Consenso de Ezulwini ${ }^{347}$, de março de 2005 - quanto à reforma da ONU, e especificamente no caso do CSONU, à demanda de 2 assentos permanente e 5 nãopermanentes, um projeto paralelo de reforma em relação ao do Brasil, representado pelo chamado G-4 (Alemanha, Japão e Índia). A partir de então, a União Africana fecha questão em torno desse projeto ${ }^{348}$, e apesar disso, o Brasil continua sua campanha em torno do projeto do G-4.

O Brasil saúda a decisão tomada pela União Africana de defender maior presença de países em desenvolvimento como membros permanentes do Conselho de Segurança. É inaceitável que continentes inteiros, como a África - com 54 países e centenas de milhões de habitantes - não tenham representação permanente em um Conselho de Segurança renovado. O Brasil defenderá com firmeza essa posição, ao mesmo tempo em que agradecemos o gesto de simpatia de países como Camarões em relação às nossas aspirações $^{349}$.

Na sequência dessa viagem, Lula foi à Nigéria, onde o tom econômico foi mais presente, e reforçou a retórica do passado comum entre os países para, juntos, trabalharem seus interesses em conjunto. Não deixou de comentar a falta de diversidade da pauta comercial entre os países, que de fato se manteve ao longo dos anos, como foi estudado acima, e agradeceu o apoio nigeriano ao Plano de Ação contra a Fome e Pobreza, lançado pelo brasileiro. Ao fim da visita, declarou à imprensa as conversas iniciais, de iniciativa do presidente nigeriano, no sentido de realizar uma cúpula entre a América do Sul e a África, o que se materializaria na Cúpula América do Sul-África no ano seguinte.

Somos orgulhosos de possuir a segunda maior população negra do planeta, atrás apenas da própria Nigéria. Essa proximidade afetiva e cultural explica por que a Nigéria é um dos mais importantes parceiros africanos do Brasil. Vejo nas relações entre nossos países um potencial imenso que precisa ser explorado com mais vigor e ousadia. Somos duas grandes nações. Nossas economias se complementam. Temos visões convergentes, interesses que coincidem na construção de um futuro de prosperidade e justiça. $\mathrm{O}$ principal resultado de minha visita deve ser a redescoberta da Nigéria pelo Brasil. (...) Nosso intercâmbio comercial registra cifras importantes. Atinge quase 4 bilhões de dólares, mas ainda não reflete a diversidade e o equilíbrio

\footnotetext{
${ }^{347}$ Common African Position on the Proposed Reform of the United Nations (Ezulwini Consensus). http://www.cfr.org/world/common-african-position-proposed-reform-united-nations-ezulwini-consensus/p25444 ${ }^{348}$ A Diplomacia Pública do MRE fornece interessante cronologia das negociações em torno da reforma do CSONU: http://csnu.itamaraty.gov.br/cronologia-das-negociacoes

${ }^{349}$ SILVA, Luis Inácio Lula da. Discurso do Presidente para o presidente de Camarões, 10.04.2005. In: MRE. Resenha de Política Exterior do Brasil, n. 96, 2005, p. 96.
} 
desejáveis para as trocas entre as duas economias. Vamos estimular nossos agentes econômicos a desenvolver o intercâmbio bilateral. ${ }^{350}$

Vocês ouviram, ontem, o Presidente Obasanjo dizendo que vai consultar a Comunidade Africana para saber do interesse de fazer uma reunião entre América do Sul e Comunidade Africana. E nós ficamos de consultar a Comunidade Sul-Americana de Nações para saber da disposição de realizarmos essa reunião com a União Africana ${ }^{351}$.

O tom econômico e comercial repetiu-se nessa declaração à imprensa, reiterando a necessidade da ampliação da pauta comercial entre os dois países. Apesar da insistência do presidente, a pauta não haveria de receber muitas mudanças, permanecendo o comércio entre Brasil e Nigéria deficitário, principalmente por causa do petróleo. Interessantemente, dessa vez não há menção a perdão de dívidas, apesar de haver negociações em andamento, que seriam finalizadas em 2006.

(...) política de comércio é uma via de duas mãos, em que você compra e vende e precisa haver um equilíbrio nessa relação, e entendendo que essa relação pode crescer muito mais do que é hoje, cabe a nós desafiarmos os nossos empresários para que visitem a Nigéria, para que descubram que tipo de parceria os nossos empresários podem fazer com os nigerianos, que tipo de produtos podemos comprar além do petróleo, e que tipo de produtos podemos vender além dos que já vendemos hoje. ${ }^{352}$

Em 2006, um novo tema surge nos discursos, qual seja, os biocombustíveis, envolvendo as dimensões econômica e cooperativa. Por exemplo, na Nigéria, por conta da Cúpula África-América do Sul, Lula lança a ideia do etanol e biocombustíveis como uma nova possibilidade de desenvolvimento conjunto do Brasil e dos países africanos, sendo ao mesmo tempo uma nova frente na luta por uma "outra globalização", mais justa, mais solidária, baseada nas parcerias estratégicas entre países em desenvolvimento. Esse tema vai estar presente em quase todos os discursos de 2006 em diante.

"Para a África, [os biocombustíveis] podem ser a chave de um novo modelo de desenvolvimento, pois diversificam a matriz energética, criam abundantes empregos, mantêm a população no campo e incidem positivamente sobre o comércio exterior dos países. Isso pode ser feito em parceria com países desenvolvidos. (...) Há exemplos de um forte potencial

\footnotetext{
${ }^{350}$ Idem. Discurso do Presidente para o presidente da Nigéria, 11.04.2005. In: MRE. Resenha de Política Exterior do Brasil, n. 96, 2005, p. 98.

${ }^{351}$ Idem. Declaração à imprensa após assinatura de atos. Abuja, 12.04.2005. In: MRE. Resenha de Política Exterior do Brasil, n. 96, 2005, p. 100.

${ }^{352}$ Ibid.
} 
de cooperação triangular com a África, que temos que expandir." Se queremos outra globalização - menos desigual, mais solidária - precisamos construir parcerias estratégicas que unam os países em desenvolvimento em torno dos mesmos objetivos e que atendam, sobretudo, os países mais pobres. Uma nova geografia política e econômica mundial só será possível se atores com afinidades escolherem o diálogo direto e a ação conjunta nos foros internacionais. ${ }^{353}$

No último ano do primeiro mandato, Lula reforça a prioridade da África em sua agenda diplomática ao seu público de líderes africanos, sempre mencionando números, como no momento abaixo. A essa altura, em setembro de 2006, quando já tinha realizado 18 viagens e visitado 17 países, ocorreria a I Cúpula do Fórum IBAS e o escritório da Embrapa em Gana já havia sido estabelecido. Desse modo, vai consolidando a posição brasileira, na dimensão política, diminuindo a diferença entre o discurso e prática, como ocorria na década de 1960, por exemplo. Como já estudado, o aumento expressivo das relações, especialmente nas dimensões econômica e cooperativa, ocorre mais no segundo mandato, mas a dimensão política, nas esferas multilaterais, de visitas de Estado e de abertura de embaixadas, tem relevante importância até aqui.

Hoje, a África é para o Brasil uma prioridade indiscutível. Desde o inicio de meu governo, visitei 17 países africanos e recebi 15 líderes da região. Tomei a iniciativa de abrir ou reativar doze embaixadas brasileiras em capitais deste continente. ${ }^{354}$

Por outro lado, os temas "clássicos" permanecem - com a inclusão do biocombustível e do etanol, inclusive no âmbito do IBAS, como podemos ver abaixo -, como a construção de uma sociedade mais justa e a reforma da ONU, apesar da posição comum africana no assunto. No segundo mandato, que também testemunha a crise financeira mundial a partir de 2008, a dimensão retórica passa a consolidar as iniciativas feitas anteriormente.

Estamos determinados a avançar na construção de sociedades mais justas e prósperas por meio de políticas econômicas responsáveis e de um compromisso sem tréguas com a melhoria das condições de vida de nossas populações mais vulneráveis. Índia, África do Sul e Brasil também podem oferecer uma contribuição decisiva para a construção de uma ordem internacional mais justa, solidária e equilibrada. (...) Partilhamos ainda o

\footnotetext{
${ }^{353}$ SILVA, Luis Inácio Lula da. Discurso do Presidente na Abertura da Cúpula ASA, Abuja, 30.11.2006. In: MRE. Resenha de Política Exterior do Brasil, n. 99, 2006, p. 184.

${ }^{354}$ Ibidem, p. 183.
} 
propósito de transformar o etanol, o biodiesel e outras fontes renováveis e limpas de energia em commodities com grande impacto sobre o mercado mundial de energia. ${ }^{355}$

O chanceler Celso Amorim reforça o discurso da nova "política africana" do governo Lula, durante discurso em comemoração ao dia da África, em 2007. Ele enfatiza o incremento comercial entre o Brasil e o continente africano durante o primeiro mandato ${ }^{356}$ e ressalta que essa aproximação não ocorre em detrimento de parceiros "tradicionais", observação que já pode ser lida como reação às críticas que a política externa passa a receber.

Agora temos uma política africana verdadeiramente intensa, que corresponde verdadeiramente à importância que a África tem para o Brasil, em todos os sentidos. (...) Recebi uma missão composta por Ministros desses países, e eles todos diziam que era visível a mudança da imagem que o Brasil tinha hoje na África, depois que o Senhor assumiu o Governo. (...) Todos esses são fatos que demonstram que nós, sob seu Goveno, sem abandonar os nossos parceiros tradicionais, conseguimos mudar o eixo da nossa política externa, dar uma atenção crescente aos países com os quais nos identificamos muito, com os quais temos cooperação intensa - seja nas Nações Unidas ou na OMC - e que também são importantes para nós como mercado, como novos horizontes de relacionamento externo. ${ }^{357}$

Na mesma ocasião, Lula reforça os dados sobre comércio e investimento, ressalta o aumento dos projetos de cooperação com países africanos, e não deixa de lado seus temas tradicionais, como a democratização da sociedade internacional, por meio da reforma do Conselho de Segurança da ONU, e a potencial cooperação possibilitada pela experiência brasileira na área de biocombustíveis. No mesmo ano, Lula vai a Burkina Faso, acompanhado de uma comitiva de empresários. Aproveita a ocasião para anunciar a abertura da embaixada brasileira em Uagadugu, mas o relevante aqui já é o contexto do contencioso do algodão. $\mathrm{O}$ Brasil já havia aberto um painel na OMC contra os subsídios aos produtores de algodão dos Estados Unidos em 2002, recebendo parecer favorável em 2005. No ano seguinte, é aberto um Painel de Implementação, cujo parecer favorável ocorreria em 2009, levando à assinatura de um memorando de entendimento para financiar um fundo de assistência técnica. Mais uma

\footnotetext{
${ }^{355}$ Idem, Discurso do Presidente na abertura da I Cúpula IBAS, Brasília, 13.09.2006, In: MRE. Resenha de Política Exterior do Brasil, n. 99, 2006, p. 126.

${ }^{356}$ Esse mesmo argumento, tomado em número relativos ao comércio total brasileiro no período torna-se um argumento dos críticos, como veremos a seguir.

${ }^{357}$ AMORIM, Celso. Discurso por ocasião do Dia da África, 25.05.2007. In: Resenha de Política Exterior do Brasil, n. 100, 2007, p. 129.
} 
vez, a política externa brasileira alia discurso à prática, ao propor o painel de implementação na OMC, para discutir contramedidas de retaliação contra os Estados Unidos, dando sustentação ao discurso de uma nova ordem internacional mais justa. No caso, o eventual acordo com os Estados Unidos iria financiar o projeto Cotton-4, já estudado no capítulo 2, transformando o projeto num dos mais bem sucedidos acordos de cooperação.

$\mathrm{Na} \mathrm{OMC}$, estamos empenhados em que as negociações de Doha possam verdadeiramente merecer o nome de "Rodada do Desenvolvimento". Com o apoio imprescindível de países africanos, o G-20 impediu que as potências industrializadas continuassem a ignorar nossas legítimas aspirações. Os países africanos souberam exercer essa capacidade de mobilização em defesa de milhares de pessoas que dependem da indústria do algodão. Burkina Faso, Benín, Chade e Malí têm demonstrado ao mundo que é possível recorrer aos mecanismos multilaterais na luta contra subsídios abusivos e injustos. O Brasil também tem levado, com êxito, esse pleito à OMC. Vamos continuar juntos nessa campanha. ${ }^{358}$

Podemos compartilhar nossa experiência na produção, escoamento e comercialização desse produto. (...) $\mathrm{O}$ acordo de cooperação técnica que assinaremos durante a visita dará a moldura necessária para a modernização do setor algodoeiro de Burkina Faso. (...) Por isso, a vitória brasileira no contencioso do algodão na OMC foi também uma vitória de Burkina Faso. ${ }^{359}$

$\mathrm{Na}$ sequência da viagem à Burkina, Lula foi à República do Congo (CongoBrazzaville), sendo o primeiro presidente brasileiro a fazê-lo. Como em outras visitas, aproveita para anunciar abertura recíproca de embaixadas, divulgar o etanol e biodiesel brasileiros e o fortalecimento das relações Sul-Sul, que teria o potencial de mudar a geografia mundial. O ponto interessante do discurso, nessa ocasião, é a listagem laudatória da experiência das empreiteiras brasileiras em construção civil, infraestrutura e prospecção, especificamente Petrobras e Vale do Rio Doce, frente à demanda congolesa por esses serviços. Ademais, como a dívida bilateral impede investimentos, Lula anuncia que estuda transformar a dívida em linhas de financiamento. Em realidade, como já estudado da questão de perdão de dívidas, já havia no período negociação no âmbito do Clube de Paris no sentido do alívio de dívidas do Congo. O perdão brasileiro ocorreria depois do período Lula, já no governo Dilma, em 2013.

\footnotetext{
${ }^{358}$ SILVA, Luis Inácio Lula da. Discurso do Presidente no Colóquio Democracia e Desenvolvimento na África, Uagadugu, 15.10.2007. In: MRE. Resenha de Política Exterior do Brasil, n. 101, 2007, p. 127.

${ }^{359} \mathrm{Idem}$. Discurso do Presidente no Encontro Empresarial em Uagadugu, 15.10.2007. In: MRE. Resenha de Política Exterior do Brasil, n. 101, 2007, p. 130.
} 
A República do Congo, como o Brasil, é um país em construção, cuja infra-estrutura de transporte, energia, saneamento básico e comunicações deverá se expandir em forma exponencial. A larga experiência das empreiteiras brasileiras nesse campo tem sido comprovada em numerosos projetos em países africanos. Inclusive na República do Congo, em anos passados. Elas podem retornar a esse pais que hoje trilha o caminho do crescimento. (...) Para facilitar a chegada desses investimentos brasileiros, meu governo está estudando transformar a dívida bilateral do Congo em linhas de financiamento para a compra de bens e serviços brasileiros. ${ }^{360}$

Em 2007, Lula ainda visitaria Angola, retomando todos os temas acima, agradecendo mais uma vez o apoio angolano pelo assento permanente no CSONU, e não deixa de lado o assunto da "revolução energética" dos biocombustíveis. Em 2008 e 2009 Lula não tem agenda tão ativa na África, ao contrário de 2010, último ano do mandato, quando faz mais uma longa viagem. Aumentam as menções à crise financeira e como as relações Sul-Sul foram uma forma de amenizar a crise nos países emergentes. Nas Cúpulas IBAS de 2007 e 2008, Lula aproveita o contexto para reforçar a retórica sobre a maior participação dos emergentes nas decisões internacionais, para não ficarem reféns dos erros cometidos pelos desenvolvidos.

Integramos o grupo de países em desenvolvimento, que mantém um diálogo estruturado com o G-8. Mas este mecanismo tem de ser aperfeiçoado de modo que nossa voz tenha influência real no tratamento dos grandes temas mundiais. De pouco vale sermos convidados para a sobremesa no banquete dos poderosos ${ }^{361}$.

Nossos países reconstruíram suas economias com grande esforço. Graças a isso vivem uma fase excepcional de expansão e de equilíbrio macroeconômico. é inadmissível, assim, que venhamos a pagar pela irresponsabilidade de especuladores que transformaram o mundo em um gigantesco cassino, ao mesmo tempo em que nos prodigavam lições sobre como deveríamos governar nossos países ${ }^{362}$.

Na II Cúpula América do Sul-África, que ocorreu na Venezuela, em Isla Marguerita, 2009, diante de um público de países em desenvolvimento, os temas sempre presentes aparecem mais reforçados tanto pelo contexto da crise, que aproxima os países emergentes, quanto pelos resultados concretos construídos nos anos anteriores, sejam as embaixadas, os

\footnotetext{
${ }^{360}$ Idem. Discurso do Presidente no Encontro Empresarial em Brazzaville, 16.10.2007. In: MRE. Resenha de Política Exterior do Brasil, n. 101, 2007, p. 133.

${ }^{361}$ Idem. Discurso do Presidente na II Cúpula IBAS, Joannesburgo, 17.10.2006. In: MRE. Resenha de Política Exterior do Brasil, n. 101, 2007, p. 136.

${ }^{362}$ Idem. Discurso do Presidente na III Cúpula IBAS, Nova Delhi, 15.10.2008. In: MRE. Resenha de Política Exterior do Brasil, n. 103, 2008, p.
} 
perdões de dívidas, os projetos de cooperação ou o intercâmbio comercial. A campanha pela reforma do CSONU continua, mas Lula não deixa de clamar pela mudança da lógica nos fóruns multilaterais pela atuação conjunta dos países emergentes.

$\mathrm{Eu}$ penso que esta Cúpula... se nós, ao terminar esta Cúpula, começarmos a trabalhar com um grupo de trabalho fixo sobre temas específicos determinados por nós, e os nossos ministros se encontrem de quando em quando, a gente poderá chegar à próxima Cúpula com resultados extraordinários, sobretudo na ação política que nós precisamos ter daqui para a frente. Não é possível que a maioria dos países, e a maioria com votos na ONU, a maioria com votos na OMC, a maioria com votos em todos os fóruns multilaterais, a gente não consiga estabelecer a nossa lógica nesses fóruns multilaterais, porque muitas vezes estamos subordinados a orientações políticas que não combinam com aquilo em que nós acreditamos.

Os trechos acimas foram extraídos principalmente de discursos do presidente e do chanceler brasileiros em contextos com predominância de um público alvo africano e de países em desenvolvimento. Por certo, a tinta é carregada na valorização de dados e informações acerca das relações Brasil-África e de relações bilaterais específicas, como também o discurso da dívida histórica, apontando como uma mudança em relação ao discurso culturalista.

Podemos inferir desse exemplo algumas observações. Em primeiro lugar, a retórica incorpora as dimensões das relações Brasil-África, como visto no capítulo 2, que aparecem em pé de igualdade e se conectam com plena convergência, como nos casos de embaixadas e visitas de Estado, se aproximando também das dimensões econômica e cooperativa, com a frequente menção de Lula aos empresários que o acompanham em missões oficiais.

Nesse caso, a presença empresarial era um movimento consciente, um estímulo para a presença e investimento de empresas brasileiras na África. Em entrevista à jornalista Amanda Rossi, Lula deixa evidente a importância que vê nos empresários:

Deixa eu te contar por que eu falo muito dos empresários. É porque nós, os dirigentes políticos, fazemos o discurso, o Itamaraty prepara o memorando, mas para as coisas acontecerem tem que ter os agentes que vão fazer as coisas acontecerem. (...) Eles tem o interesse econômico. Meu medo é que, se não tiver o empresariado por trás, as coisas ficam mais difíceis de 
acontecer. Você tem que despertar interesse neles. ${ }^{363}$

Além disso, Lula, durante as viagens, questionava o reduzido interesse das empresas brasileiras e apresentava as propostas delas às autoridades africanas, colocando as partes em contato, com o alegado intuito de promover o interesse nacional ${ }^{364}$. Em segundo lugar, o discurso em si mantém coerência interna ao longo do período. A retórica da prioridade africana na agenda externa brasileira passa de um discurso inicial para um argumento concreto ao final do período. O argumento da "nova geografia mundial", com o aumento da importância dos emergentes e do multilateralismo também fica mais concreto com o surgimento e consolidação do IBAS e da Cúpula ASA, e da proatividade brasileira na OMC, com o contencioso do algodão e dos vários projetos de cooperação.

Em terceiro lugar, nota-se também o tom geopolítico de temas, por exemplo, sobre a reforma do CSONU e da "revolução do biocombustível", que foram mais difíceis de emplacar. A reforma do Conselho sofre a dificuldade da posição comum africana, apesar da constante manifestação de apoio à causa brasileira individualmente pelos países. A ideia dos biocombustíveis ocorre tanto pelo argumento de diminuir a dependência do petróleo quanto pelo potencial de venda de automóveis com motores a álcool aos africanos ${ }^{365}$, o que depois é um pouco dificultado com a própria descoberta das jazidas do pré-sal brasileiro.

A dimensão retórica da política externa para a África não é, portanto, irrelevante. Ao contrário, ela é usada como instrumento de política externa e funciona como reforço à política externa como um todo, pois permeia todas as dimensões e esferas. Entretanto, apesar de negar a busca de "liderança do mundo em desenvolvimento", fica evidente, por trás do discurso, a procura por hegemonia no continente africano, por meio do soft power brasileiro, e até de um hard power por meio das empreiteiras; outro exemplo disso é a insistência em transformar o etanol em uma commodity, na qual o Brasil teria vantagens.

\subsection{A política para África na mídia impressa}

A política externa do governo Lula, com mais ênfase do que em governos anteriores, foi usada como ferramenta para desenvolvimento econômico e de prestígio internacional, conforme a própria análise dos discursos acima permite afirmar. As diversas viagens realizadas pelo então presidente, por exemplo, foram o início do número crescente de críticas

\footnotetext{
${ }^{363}$ ROSSI, Amanda. Moçambique, o Brasil é aqui. Rio de Janeiro: Record, 2015, p. 52.

364 Ibidem, p. 59.

365 Ibidem, p. 331.
} 
à nova política externa. Do mesmo modo que ganhavam atenção no exterior, as relações externas do período passam também a ser alvo comum da grande mídia impressa, veículo não apenas para jornalistas expressarem suas discordâncias, mas também para antigos embaixadores, políticos e estudiosos. De modo geral, como aponta Kjeld Jakobsen, as críticas seguem o argumento de que a política externa do período foi influenciada sobremaneira pela visão de mundo do Partido dos Trabalhadores, que teria quebrado uma longa tradição de preponderância do MRE na formulação da política externa e consequentemente transformando uma política de Estado em uma política de governo ${ }^{366}$.

De acordo com Guilherme Casarões, por meio de um levantamento de editoriais dos jornais Folha de São Paulo e Estado de S. Paulo do período, ocorreu uma convergência de posições contra a política externa de Lula. Os principais argumentos giram em torno do personalismo excessivo do presidente; o seu comportamento terceiro-mundista e antiamericanista; e a demasiada influência do "conselheiro especial" Marco Aurélio Garcia nas decisões de política externa ${ }^{367}$.

A quantidade de editoriais nesse jornais sobre relações externas aumentou consideravelmente no governo Lula. Segundo Casarões, a Folha publicou 130 editoriais sobre o assunto, enquanto o Estado publicou 280 opiniões no período - considerando que no último mandato de Fernando Henrique, esse mesmo jornal havia feito 64 editoriais no assunto. Dessas reportagens, continua Casarões, mais de 50\% deles, no caso da Folha, são explicitamente críticos às ações de política externa de Lula, enquanto no caso d'O Estado, mais de $60 \%$ são negativos.

Mais especificamente, a política para a África do período também sofre das mesmas críticas. A Folha não considera a aproximação prejudicial como um todo, enxergando um lado simbólico no movimento, mas insiste em criticar os aspectos técnicos e comerciais de algumas ações, além de não aceitar as relações com países governados por ditadores. $\mathrm{O}$ aspecto positivo visto pelo editorial da Folha vincula-se ao discurso da dívida histórica.

Não se deve negar a existência de aspectos positivos nem o êxito, no nível simbólico, do périplo do presidente Luiz Inácio Lula da Silva pela África, continente com o qual o país tem dívidas históricas. ${ }^{368}$

\footnotetext{
${ }^{366}$ JAKOBSEN, Kjeld Aagard. Desventuras de alguns críticos da política externa do governo Lula. In: Lua Nova, n. 89, 2013, p. 276.

${ }^{367}$ CASARÕES, Guilherme Stolle Paixão e. A mídia e a política externa no Brasil de Lula. In: Austral, v. 1, n. 2, 2012, p. 220.

${ }^{368}$ Folha de S. Paulo. "Frustração na África". 13 de abril de 2005, p. A2
} 
$\mathrm{Na}$ ocasião do primeiro périplo africano empreendido por Lula, em 2003, a Folha enviou a jornalista Eliane Cantanhêde para acompanhar a comitiva, que talvez tenha sido a maior entre todas as viagens feitas por Lula à África. Além da cobertura dos compromissos presidenciais, o jornal publica rápidas opiniões sobre as intenções do Brasil na África. $\mathrm{O}$ conteúdo leva traços de sarcasmo, com o objetivo de diminuir tanto a importância da iniciativa de Lula quanto a própria importância dos países visitados. Cantanhêde afirma que a viagem de Lula quer construir a imagem de "líder dos pobres", Lula "falará com tom, voz e jeitão de líder mundial”.

Lula chega hoje à África para uma viagem que tem caráter simbólico, político e econômico, porque faz parte do esforço brasileiro de ocupar um lugar ao sol entre os países líderes do mundo. Em resumo, é preciso liderar os pobres para poder negociar em conjunto e com mais força com os ricos. O GX na OMC é um laboratório. (...) No quesito simbologia, Lula desembarcará na África por São Tomé e Príncipe só como gesto de boa vontade. O país, uma pequena ilhota, foi o último de língua portuguesa a ter uma embaixada brasileira, que acaba de ser inaugurada. ${ }^{369}$

Segundo a jornalista, a retórica de Lula inclui a menção à sua origem humilde para disfarçar sua própria arrogância, aproximando os dramas e misérias brasileiros e africanos. De todas as iniciativas e projetos da diplomacia brasileira, a jornalista conclui que "a sensação que fica, dos gestos, dos discursos e promessas, é que Lula não quer ser só o salvador da pátria, mas de todas as pátrias" ${ }^{370}$. Interessantemente, o jornal não faz uma cobertura tão próxima nas outras viagens de Lula à África.

A Folha releva, de certo modo, as relações com os países não democráticos, afinal, considerando a quantidade de países nessas condições no mundo, muitas relações seriam encerradas, e, logo, não é um critério a ser seguido. O problema seria ignorar completamente as violações de Direitos Humanos, como acusa a diplomacia de o fazer, para atingir os fins desejados, no caso, o voto para a reforma do CSONU.

Isso não significa, é claro, que o Itamaraty esteja autorizado a esquecer os compromissos do Brasil com a democracia e os direitos humanos. O Ministério das Relações Exteriores ensaiou alguns passos nessa direção no auge de sua obsessiva campanha por uma vaga permanente no Conselho de Segurança da ONU. Em busca de apoio, o Brasil depositou alguns dos votos mais vergonhosos da história de sua diplomacia, como

\footnotetext{
${ }^{369}$ Folha de S. Paulo, "É uma África”, 02 de novembro de 2003, p. A2.

${ }^{370}$ Folha de S. Paulo, "Miséria", 06 de novembro de 2003, p. A2
} 
abster-se na moção que exigia o julgamento dos responsáveis pelo genocídio de Darfur ${ }^{371}$.

Por outro lado, de acordo com o Estado de S. Paulo, a aproximação do Brasil para a África era completamente "ideológica" e uma tentativa de "doutrinação terceiro-mundista" no interior da tradicional e respeitada diplomacia brasileira. O jornal publica críticas mais diretas à nova política externa para a África. Em todo o período, há pelo menos 7 editoriais questionando as viagens e a prioridade que a África passa a ter na política externa brasileira. Sem utilizar o sarcasmo que o outro periódico faz uso, o Estado desdenha das primeira iniciativas, colocando-as como "sonhos", "ilusões" e "fantasias", diminuindo inclusive a figura do Ministro de Cultura da época, o cantor Gilberto Gil. A proposta, já então aventada, de criar novas instituições para ajuda de países em desenvolvimento é colocada como fora da realidade e constrangedora.

Corre o presidente Lula o sério risco de que o seu giro por cinco países africanos seja lembrado como uma mistura de um gênero cinematográfico com um gênero literário. (...) A associação com o cinema vem das entusiasmadas exibições (...) do ministro da Cultura, Gilberto Gil, que deve ser caso único do mundo de membro de uma equipe de governo nacional que se expressa cantando e dançando, como o inesquecível Fred Astaire. (...) É difícil, de fato, enxergar qualquer parentesco com a realidade no anúncio feito pelo presidente na capital angolana, Luanda, de incluir os países africanos na estrutura de financiamento internacional que ele imagina que possa ser efetivamente criada na América Latina ${ }^{372}$.

Assim como a Folha, o Estado não perdoa qualquer relação com as ditaduras africanas. No caso, o colunista João Mellão Neto, em opinião de 2004 acerca da "enésima" visita de Lula a Cabo Verde e Gabão, enfatiza, e exagera, a figura do presidente do Gabão como ditador "pérfido", e afirma explicitamente que Cabo Verde é tão insignificante que ninguém saberia de sua existência não fosse pela cobertura jornalística sobre a visita de Lula. Aqui, temos um evidente exemplo do discurso vinculado à agenda econômica e comercial, favorecendo apenas os países ocidentais, desprezando tanto os países africanos quanto as possibilidades de trocas, sejam materiais ou não, entre o Brasil e esses países, além de colocar essas relações como foram do interesse nacional brasileiro - as "necessidades estratégicas".

Suas expedições têm de atender a necessidades estratégicas do País

${ }^{371}$ Folha de S. Paulo, "Diplomacia e Ditadura", 17 de outubro de 2007, p. A2.

${ }^{372}$ O Estado de S. Paulo, 09 de novembro de 2003, p. A2. 
que representa (...). Assim sendo, cabe indagar: que diabos o Lula foi fazer de novo na África? As populações somadas de Gabão, de Cabo Verde e de São Tomé e Príncipe não ocupariam metade da zona leste de São Paulo. E, em termos econômicos, esses países não produzem mais do que uma empresa brasileira do porte da Vale, por exemplo. O que essas nações podem comprar de nós? Lula, generosamente, acaba de perdoar US\$ 36 milhões de dólares que o Gabão nos deve. (...) o Gabão é uma pérfida ditadura e sua renda per capita é muito próxima da do Brasil. Pobreza por pobreza, não deveríamos antes cuidar da nossa? ${ }^{373}$

A tese de anti-americanismo da política externa brasileira pode ser encontrada em opiniões publicadas n'O Estado. Em 2007, o jornal pergunta a Carlos Pio, professor de Economia Política, se a diplomacia Sul-Sul tem dado resultado. Em sua opinião, a política externa de então ignora os países ricos e busca a liderança dos "países mais atrasados do mundo, que desprezam a lógica implícita ao sistema internacional.” A imagem de terceiromundismo transparece na afirmação de que o Brasil busca ser líder do mundo em desenvolvimento e de blocos e coalizões que resistem à hegemonia econômica, política e militar dos Estados Unidos.

A partir de uma orientação construída sobre percepções anticapitalistas, anti-americanas e anti-liberais dos interesses nacionais, da dinâmica da política internacional e dos custos e benefícios das opções existentes para a inserção internacional do Brasil, o governo elegeu como prioridade o adensamento de relações com países e blocos que resistem à hegemonia econômica, militar e política dos Estados Unidos. (...) parece evidente que o Brasil se orienta por uma perspectiva que despreza o sentido da evolução da política e da economia internacional nos últimos 50 anos. $^{374}$

Os argumentos usados contra a política externa para a África, principalmente no caso do Estado de S. Paulo, insistem na suposta insignificância do fluxo comercial entre Brasil e África; na concentração de produtos da pauta comercial; na imoralidade em dialogar com dirigentes africanos que estão há décadas no poder; na irresponsabilidade em renegociar dívidas externas; na suposta preferência de países em desenvolvimento sobre países tradicionais; e na autopromoção do então presidente. Não raro, também é alvo da acusação de orientação ideológica, como se a alternativa dada - manutenção da prioridade da política externa nos Estados Unidos e Europa - fosse esvaziada de ideologia.

O caso do perdão de dívidas é sintomático; como foi analisado neste trabalho, o Brasil

${ }^{373}$ O Estado de S. Paulo, 30 de julho de 2004, p. A2.

${ }^{374}$ O Estado de S. Paulo, 15 de outubro de 2007, p. A8. 
vem renegociando dívidas dentro de um contexto internacional nesse sentido, e a política externa brasileira o utiliza como mais um argumento retórico de aproximação, solidariedade e estímulo ao comércio, e inclusive Fernando Henrique assim o fez, em relação à dívida com Moçambique, negociada no fim de seu mandato. Nesse caso, inclusive, podemos ver a diferença de tratamento dado, pela imprensa, a Fernando Henrique e a Lula no tema.

"No uso de minhas prerrogativas, tomei a decisão de autorizar a redução em 95\% da dívida moçambicana com o Brasil", disse FHC. O perdão integral dependeria de autorização do Congresso. $O$ anúncio do perdão da dívida externa moçambicana foi a maior surpresa do dia. Ao discursar ontem na abertura da 3a reunião de cúpula dos países de língua portuguesa, em Maputo, FHC incorporou o papel de líder do bloco formado por sete países e anunciou o repasse de US\$ 1,5 bilhão para várias ações no continente africano. ${ }^{375}$

A imprensa, no caso de Lula, ao contrário, enxerga como um disparate tais medidas, como se fossem unilaterais e partissem exclusivamente do presidente Lula, ignorando medidas semelhantes de seu antecessor e desconsiderando que se trata de uma política de Estado. Podemos verificar isso num discurso de Celso Lafer, ainda na condição de chanceler de Fernando Henrique, em Conferência sobre Países Menos Desenvolvidos, no qual afirma as negociações em andamento com países em débito, que eventualmente seriam finalizadas, seja no curso do governo Lula ou no governo Dilma.

Em alguns casos temos ido além das concessões acordadas no Clube de Paris. O Brasil já propiciou, ou está finalizando negociações neste sentido, o alívio da dívida a onze países, seja sob a forma de redução nos serviços da dívida ou de redução do débito ${ }^{376}$.

Os trechos dos jornais aqui selecionados compartilham da visão de que a política externa de Lula, e especialmente aquela voltada para África, foi tendenciosa por permitir um protagonismo muito forte em relação da participação do país no chamado Sul Global, um personalismo exacerbado do presidente, e uma influência na política externa alheia ao MRE. Neste ponto, o Estado de S. Paulo considerava que a formulação da diplomacia ocorria em "quatro cabeças", com um chanceler de poder reduzido, um secretário-geral de forte ideologia, um assessor internacional amador, e um ministro amigo de Fidel Castro $^{377}$. Na

\footnotetext{
${ }^{375}$ Folha de S. Paulo, "Presidente perdoa dívida de Moçambique", 18 de julho de 2000.

${ }^{376}$ MRE. Resenha de Política Exterior do Brasil, n88, $1^{\circ}$ Sem. 2001, p. 164.

${ }^{377}$ O Estado de S. Paulo, 27 de abril de 2005, p. A2.
} 
opinião da Folha, a política externa de Lula era desafinada, principalmente por conta da aproximação com países não democráticos.

O tom de alguns argumentos específicos em relação à política de aproximação com a África nesse período remete à forma das críticas à Política Externa Independente de Jânio Quadros, no começo da década de 1960. José Honório Rodrigues já apontava e criticava essa posição, que vinha do próprio contexto de preconceito racial brasileiro, desde os tempos coloniais. Rodrigues denomina essa posição de "complexo de caiação",378, no qual críticos e intelectuais, principalmente da elite, valorizam apenas a aproximação brasileira com o mundo branco e ocidental. A valorização da mestiçagem, muito em discussão em meados do século $\mathrm{XX}$, faz parte desse complexo, pois o branqueamento conduzido pela miscigenação significaria, para aquela elite, limpeza e melhoria de raça ${ }^{379}$.

A política externa de Jânio Quadros, com suas iniciativas de aproximação e valorização de laços culturais com o continente africano, provocou, segundo Rodrigues, o retorno de argumentos "caiados", pelos quais a África nada poderia oferecer ao Brasil, que deveria se esforçar em ampliar as já tradicionais relações com os países ocidentais. Os argumentos de então refletem a priorização do aspecto econômico-comercial, assim como alguns argumentos recentes também o fazem, mas também insistem em afirmar a não existência de preconceito racial no Brasil. Um exemplo desse discurso foi encontrado no artigo escrito por Theophilo de Andrade, no Fundo José Honório Rodrigues, cuja guarda é responsabilidade do Instituto de Estudos Brasileiros.

"A côr era uma coisa que já não mais preocupava a ninguém. A República está cheia de estadistas, políticos, professores, jornalistas, escritores e poetas de todos os matizes: brancos, louros, morenos, cafusos, curibocas, índios, mulatos e negros. (...) Eis senão quando nos vimos surpreendidos, em nossa política externa, com uma revivescência do amor aos negros, que aliás, nem se davam conta de terem epiderme diferente ou cabelinho carapinha pois ninguém fazia discriminação contra eles, por motivo de côr. (...) Chama-se a isso recorrer às origens. Estamos a descobrir a África, tal como os portugueses de 1400. (...) Possuem eles alguma coisa para nos vender? Nada. Podem comprar-nos alguma coisa? Nada. São países ainda subdesenvolvidos, produtores de artigos de base, o que vale dizer, nossos concorrentes no mercado internacional. Porque, então, estamos a preocupar-nos tanto com êles, como se fossem os portadores da civilização do futuro? Não sabem a resposta? É simples: complexo da mãe preta. A

${ }^{378}$ Sobre o complexo de caiação, ver RODRIGUES, Interesse Nacional e Política Externa. Rio de Janeiro: Civilização Brasileira, 1966, p. 58 e Janeiro: Civilização Brasileira, 1970, p. 67.

${ }^{379}$ RODRIGUES, op. cit., 1982, p. 112. 
dívida do leite, contraída na primeira idade." 380

Além de relativizar o preconceito racial no Brasil, a política para a África é colocada como uma aproximação ideologizada da África. Percebe-se uma narrativa muito próxima da atual para criticar uma política africana, uma posição já superada, mas herdada pela grande mídia, que mantém vivo o complexo de caiação. O tom culturalista de então é abafado atualmente pela predominância dos argumentos econômico-comerciais mais atuais, além da condenação das relações com países não democráticos.

Nos discursos de Lula, a questão cultural e histórica é explícita, mas vai além tanto da questão econômica quanto da cultural. $\mathrm{O}$ ex-presidente utiliza o tema histórico-cultural como meio de fortalecer as relações bilaterais, utilizando-o como ponte para outras áreas, como comércio, cooperação, investimentos. De certo modo, por trás do reconhecimento da dívida histórica, está a busca por hegemonia brasileira no espaço africano.

\subsection{A política externa para África no meio acadêmico e intelectual}

Mesmo que no meio acadêmico e intelectual não haja uma polarização como ocorre na grande mídia, há um debate sobre a política externa brasileira para a África, em particular, e sobre a política externa do governo Lula em geral. Neste trabalho, consideramos como meio intelectual artigos e opiniões de profissionais ligados ao meio diplomático, como embaixadores e diplomatas, e livros e artigos de pesquisadores e professores das áreas de Relações Internacionais e História. O debate, por isso, tende a ser mais aprofundado do que aquele apresentado acima, mas também com diferentes matizes. No caso dos diplomatas e embaixadores aqui selecionados, predomina a crítica.

Um artigo do embaixador e antigo diretor do Departamento de África do MRE, José Vicente de Sá Pimentel, na Revista Brasileira de Política Internacional, é representativo do grupo de intelectuais que não concordam com a política externa do governo Lula em geral, e com a política para a África em particular. Apesar do artigo ter sido publicado em 2000, ele se encaixa no pensamento geral dos críticos. Pimentel lembra o chanceler Luiz Felipe Lampreia na sua afirmação de que a África é "um objetivo insubstituível da política externa brasileira", pois foi parte essencial na formação econômica e social e na construção da identidade

\footnotetext{
${ }^{380}$ ANDRADE, Theophilo de. Complexo da Mãe Preta. O Jornal, 23 de abril de 1961. Fundo José Honório Rodrigues. IEB/USP.
} 
nacional brasileira, e com isso, as relações com o continente africano são um ponto estratégico na inserção internacional do Brasil ${ }^{381}$.

Porém, aponta que as discussões sobre os temas africanos são emocionais. Na sua visão, existem dois grupos que discutem esses temas: os nostálgicos e os catastrofistas. Os primeiros clamam pelas responsabilidades históricas do Brasil com o continente africano, e se queixam da falta de uma "política africana" (grifo dele), como a da década de 70. O segundo grupo defende que, tendo em vista as condições sociais e econômicas africanas, nada há de ser feito, logo, não se justifica uma prioridade nas relações.

Para Pimentel, não deve haver uma insistência na formulação de uma política propriamente africana porque não existe, por exemplo, uma "política europeia". Existindo aquela, entende-se que há "repartição equânime de meios" para parceiros como Angola e Djibuti, por exemplo. Defende assim, uma seletividade, de acordo com as oportunidades oferecidas por cada país. Além disso, seria necessário convencer setores internos da sociedade brasileira para aumentar as relações Brasil-África. Para tanto, as relações econômicocomerciais são as mais fundamentais tanto para ajudar o continente africano quanto aumentar o apoio da sociedade no relacionamento com os africanos. Diante dos limites de poder brasileiro, a diplomacia deve se concentrar em parcerias já consolidadas, como Angola, Nigéria, África do Sul e CPLP.

O falecido embaixador e chanceler de Fernando Henrique, Luiz Felipe Lampreia, ao escrever seu livro de memórias diplomáticas, segue exatamente o mesmo caminho de pensamento. Escrevendo em 2009, ele reafirma a citação de Pimentel, justificando a atenção brasileira à África pela origem africana da população brasileira. Uma atenção maior significaria concorrer com as ex-potências, que possuem preferências comerciais. Relações com Angola e África do Sul são as prioridades brasileiras, uma vez que não seria possível expandi-las.

Não devemos olhar a África apenas como o maior contingente de votos na ONU, capaz de ajudar o nosso país a conseguir uma cadeira permanente no Conselho de Segurança. Por isso, abrir embaixadas em todos os países africanos não faz sentido, na minha opinião, já que, além de ser um gasto enorme para o contribuinte, é impossível atender às expectativas criadas com esse gesto. O Brasil termina sendo uma decepção para eles. (...) Não podemos esperar competir com a França, a Inglaterra ou a União Europeia nesses campos [comércio, financiamentos, apoio educacional e

\footnotetext{
${ }^{381}$ PIMENTEL, José Vicente de. Relações entre o Brasil e a África Subsaárica. In: Revista Brasileira de Política Internacional, n. 43, 2000.
} 
cooperação militar]. A alternativa tem que ser mais limitada, centrada sobretudo na cooperação cultural, que é nosso maior vínculo, na cooperação técnica e no financiamento a empresas brasileiras, sendo imperativa a definição de prioridades. A nossa no governo FHC eram os países de língua portuguesa e a África do Sul. Foram esses os países com os quais estabelecemos laços mais fortes ${ }^{382}$.

A abertura de embaixadas fica vinculada, nesse pensamento, ao movimento político da campanha pelo assento permanente do CSONU. As prioridades brasileiras no continente africano seriam a cooperação técnica e cultural e financiamento de empresas brasileiras, limitadas a parceiros tradicionais, como África do Sul e PALOPs. A partir dessa afirmação, podemos observar, em primeiro lugar, que não houve um "silêncio" da política externa brasileira em relação à África, mas uma limitação consciente. Em segundo, nota-se marcadamente as diferenças de iniciativa do governo Fernando Henrique e do governo seguinte, com a expansão das relações, sobretudo no que diz ao número de países parceiros e quantidade de projetos de cooperação, por exemplo.

Por sua vez, o embaixador aposentado Rubens Barbosa detalha mais as suas críticas à política externa do governo Lula em geral, em diversos artigos de opinião de jornais e em meios televisivos. O embaixador centra seus argumentos na suposta partidarização e ideologização no processo decisório da política externa, principalmente por influência do então Assessor Internacional Marco Aurelio Garcia, que também havia coordenado os programas de governo do PT.

A partidarização da política externa ficou nítida desde o inicio do primeiro mandato de Lula e a influência do Partido dos Trabalhadores no processo decisório do Itamaraty foi perceptível. (...) Desde o início do governo Lula, a política externa foi exercida deliberadamente a partir da visão de mundo do PT e se deixou guiar pelos programas formulados pelo partido. $^{383}$

Segundo o embaixador, era perceptível que o MRE, como instituição, não escondia que estava a serviço do partido vencedor das eleições, descaracterizando a política externa como política de Estado, deixando de representar os interesses permanentes do Brasil. Além disso, coloca as relações externas brasileiras em uma dicotomia, pois o aumento das relações

\footnotetext{
${ }^{382}$ LAMPREIA, Luiz Felipe. O Brasil e os ventos do mundo: memórias de cinco décadas na cena internacional. Rio de Janeiro: Objetiva, 2012, recurso eletrônico, ref. Kindle 4152.

${ }^{383}$ BARBOSA, Rubens. Política Externa de dois governos. 8o Fórum de Economia da FGV, 2011, p. 2. Disponível em http://cnd.fgv.br/node/303.
} 
Sul-Sul implicou necessariamente em uma diminuição da cooperação com as nações desenvolvidas.

Nesse último ponto, no entanto, o embaixador aponta que a diferença do governo Lula com os antecessores é a introdução de "forte componente ideológico na formulação e execução da política externa (temperado de quando em quando por doses de pragmatismo)", pois as ações de Lula colocadas como avanços, conquistas ou novidades têm origem em administrações anteriores, como a negociação multilateral na $\mathrm{OMC}$; a reforma da $\mathrm{ONU}$ e do CSONU; aproximação e integração regional na América do Sul; e fortalecimento das alianças Sul-Sul. Desse modo, na visão do embaixador, apesar da ideologização e partidarização, os únicos aspectos positivos da política externa do governo Lula teriam origem, na verdade, no governo anterior.

Uma análise objetiva da política externa de Lula não pode deixar de reconhecer seus resultados positivos, em grande parte, naquilo que representou continuidade da política de FHC.

Pode ser contabilizada nessa categoria a maior presença do Brasil no mundo. A projeção externa do pais se explicitou na diplomacia presidencial que o presidente Lula exercitou com maior vigor do que o presidente FHC, que a iniciou. As ações brasileiras nas discussões em diferentes fóruns multilaterais nos setores de comercio exterior, meio ambiente, mudança clima, energia (fóssil, pelas descobertas do pré-sal, e renovável), alimentação, direitos humanos aumentaram a visibilidade do pais. Como um "global trader", o Brasil ampliou pouco sua participação no comércio internacional, mas em termos nominais, os valores do intercâmbio comercial Sul-Sul aumentaram. ${ }^{384}$

Em relação ao continente africano, a política externa do governo Lula teria colhido apenas insucessos. Assim como Lampreia, Barbosa vincula a aproximação africana apenas com os votos para a reforma do CSONU e lembra da posição comum africana na questão da reforma. Não deixa de apontar também para a questão econômico-comercial, afirmando que o porcentual do comércio com a África manteve-se no mesmo patamar de 2002. Aqui, em oposição ao discurso oficial do chanceler Amorim, como apontado anteriormente, o argumento comercial torna-se um argumento contrário à política para África, pois é tomado em termos relativos, sem a devida nota do grande crescimento do intercâmbio comercial brasileiro como um todo no período.

\footnotetext{
${ }^{384}$ Ibidem, p. 7.
} 
O fracasso nas tentativas de levar adiante a reforma das Nações Unidas, sobretudo a do Conselho de Segurança, não deram ao Brasil o ambicionado assento permanente. Acrescente-se nesse particular que a África, uma das principais prioridades da política externa e objeto de sucessivos gestos de aproximação, votou contra os interesses do Brasil. (...)

A ampliação das relações comerciais com os países em desenvolvimento (aliança Sul-Sul) pouco resultado apresentou em termos relativos. Depois de oito anos de governo e de grande esforço de promoção comercial, o intercâmbio com o Oriente Médio e com a África, em 2010, representam respectivamente $4,5 \%$ do total das exportações brasileiras, pouco acima do percentual de $2002 .{ }^{385}$

O argumento econômico-comercial não é aprofundado de nenhuma maneira, apresentado apenas como o percentual do total do comércio, sem qualquer discussão sobre as exportações e importações, produtos específicos e tendências, algo que é realizado principalmente por pesquisas acadêmicas ${ }^{386}$.

O diplomata e professor universitário Paulo Roberto de Almeida também se dedicou à análise da política externa do governo Lula, em diversos artigos em revistas da área de Relações Internacionais. O interessante na análise de suas produções é a mudança de tom ao longo do governo Lula. A princípio, apontava a coerência da visão de mundo do PT e a política externa que passa a ser implementada, inclusive vendo de forma positiva a intenção de fortalecer as relações com países em desenvolvimento, especificamente com os países africanos. Além disso, não via no programa de governo do PT ou nos primeiros discursos de Lula uma incongruência com a política de Estado que seria a política externa brasileira, pelo contrário, ia ao encontro das tradições do Itamaraty.

Em suma, constatadas algumas variações conceituais e a nova ênfase na defesa afirmada da soberania nacional, a política externa do governo Lula não parece distanciar-se, significativamente, da diplomacia conduzida de maneira bastante profissional pelo Itamaraty no período recente, conformando aliás uma concordância de princípio com a tradicional "diplomacia do desenvolvimento" impulsionada pelo Brasil desde largos anos. (...)

De novidade, mesmo, nessa primeira mensagem ao Congresso, registre-se a decisão de reafirmar a importância da política africana e a intenção de ampliar a presença diplomática naquele continente ${ }^{387}$.

\footnotetext{
${ }^{385}$ Ibidem, p. 9-10.

${ }^{386}$ Como o capítulo 2 deste trabalho, e as teses de RIBEIRO, Cláudio Oliveira. Relações Político-Comerciais Brasil-África (1985-2006). Tese FFLCH-USP, 2007; e as já citadas teses de OLIVEIRA, Henrique Altemani. Op. cit., 1987 e FERREIRA, Walace, op. cit., 2015.

${ }^{387}$ ALMEIDA, Paulo Roberto de. A Política Internacional do Partido dos Trabalhadores: da fundação à diplomacia do governo Lula. In: Revista de Sociologia Política, n. 20, jun. 2003, p. 100.
} 
Em capítulo de livro de 2005, Almeida continua a enxergar a política externa de Lula positivamente, ressaltando seus aspectos de mudança, ao mesmo tempo que preservava elementos de continuidade, afastando argumentos de "partidarização" ou "ideologização". A continuidade de elementos, segundo ele, são reflexos de um realismo político, uma vez que, na condução do governo, Lula e sua equipe teriam percebido as limitações de poder do Brasil no cenário internacional. $\mathrm{O}$ aspecto econômico-comercial ainda é predominante na sua análise, e seu argumento central é de que a nova política externa não apresentaria mudanças bruscas, mas enfatizaria algumas linhas de ações.

Em matéria de política externa, as linhas de ruptura são mais difíceis de serem implementadas, ocorrendo uma tendência natural à preservação dos elementos de continuidade. (...) Uma primeira constatação que se pode fazer a propósito dessa política externa é a de que se trata de uma diplomacia evolutiva, tanto em seus contornos conceituais como em seu modus operandi.

De modo geral, a "nova diplomacia" não parece afastar-se muito da "velha", com talvez uma afirmação mais enfática dos interesses nacionais e da defesa da soberania. (...) A defesa do multilateralismo não destoa, em praticamente ponto nenhum, das conhecidas posições defendidas tradicionalmente pela diplomacia brasileira.

Trata-se, talvez, de tornar mais enfáticas algumas linhas de atuação [em referência a posições econômico-comerciais] que já vinham sendo seguidas, com as hesitações que se sabe, pela diplomacia do governo anterior, mas não algo que represente inovação absoluta para todos aqueles já engajados, dentro e fora do Itamaraty, nesse tipo de exercício negociador $^{388}$.

As relações do Brasil com África não são citadas especificamente. Em 2012, numa completa mudança de tom, Almeida publica um artigo na Revista Política Externa extremamente crítico da política externa de Lula. Se antes a política externa do governo Lula não parecia se afastar das linhas tradicionais do Itamaraty, após 2010 teria sido possível notar que essa política era completamente destoante da diplomacia brasileira de governos anteriores.

Independentemente dos adjetivos que possam ser agregados a uma diplomacia que, de fato, destoou, bastante, de orientações diplomáticas

${ }^{388}$ ALMEIDA, Paulo Roberto de. A política internacional do PT e a diplomacia do governo Lula. In: ALBUQUERQUE, José A. Guilhon. Sessenta anos de política externa brasileira:1930-1990, v. 1, Rio de Janeiro: Lumen Juris, 2006, p. 592, 594-595, 598. 
tradicionais de diferentes governos brasileiros e, também, do estilo de atuação do Itamaraty, cabe agora, uma vez encerrado esse período de oito anos de "diplomacia ativa", empreender uma análise abrangente de suas realizações, bem como efetuar um balanço das conquistas e das frustrações que a marcaram ${ }^{389}$.

Almeida adere aos argumentos de partidarização da política externa brasileira, com influência principalmente advinda de José Dirceu, durante um período chefe da casa civil, e de Marco Aurelio Garcia, assessor presidencial para assuntos internacionais. A agenda internacional e regional brasileira teria sido sequestrada por uma visão de mundo "cubana", comprometida em "mudar a relação de forças no mundo" e "afastar a dominação do império". As relações Sul-Sul eram parte do plano para "alterar o eixo do poder" e criar uma "nova geografia comercial internacional" - um retorno a alinhamentos maniqueístas do passado ${ }^{390}$. A agência do Itamaraty na formulação da política externa brasileira teria sido enfraquecida pela agenda internacional do PT.

A definição de objetivos do governo Lula no plano econômico multilateral é indissociável de sua postura em relação aos grandes temas políticos que frequentavam a agenda "internacional" do PT: adesão vaga ao terceiro-mundismo de épocas passadas, com sua carga de anti-hegemonismo e anti-imperialismo bastante explícitos, apenas temperados pela postura profissional do Itamaraty em cumprir essa nova agenda política com os cuidados formais requeridos de toda ação diplomática responsável. ${ }^{391}$

Especificamente sobre as relações Sul-Sul, Almeida afirma que as coalizões Sul-Sul, como o IBAS, já são de antemão impregnadas com a ideologia partidária predominante, de afastamento dos centros de poderes “imperiais". Na sua visão, mesmo em 2012, não era possível verificar qualquer resultado realista advindo das coalizões ou arranjos cooperativos considerando, como estudamos no capítulo 2, que há diversos resultados e posições que podem ser daí inferidos, mas não que simplesmente não haja resultados possíveis dos agrupamentos. A participação em fóruns multilaterais ou regionais, na sua opinião, são a retomada do estilo dos anos 1970, numa divisão do mundo em Norte e Sul.

$\mathrm{Na}$ ausência de relatórios objetivos - à margem das próprias declarações políticas - ou de uma avaliação independente quanto aos

\footnotetext{
${ }^{389}$ ALMEIDA, Paulo Roberto de. A diplomacia da era Lula: balanço e avaliação. In: Revista Política Externa, v. 20, n. 3, 2012, p.2. Disponível em http://politicaexterna.com.br/503/diplomacia-era-lula-balanco-avaliacao/

${ }^{390}$ Ibidem, p. 4.

${ }^{391}$ Ibidem, p. 12.
} 
resultados dessa cooperação - que mobilizou muitos recursos humanos e financeiros em dezenas de reuniões de grupos de trabalho ao longo dos anos - é praticamente impossível oferecer um balanço realista dos resultados alcançados por essa plataforma, mas uma percepção meramente visual das condições existentes em cada um dos países revelaria dificuldades imensas para a superação das heterogeneidades objetivas existentes nos mais diversos campos de relevância econômica, política ou social para justificar os esforços e recursos envolvidos numa empreitada definida a priori, de modo político, sem uma análise técnica prévia de suas condições de implementação. ${ }^{392}$

Quanto à África, na única menção ao continente, Almeida passa a incluir o argumento presente também na grande imprensa na condenação de relações com países não democráticos, rotulando as viagens de Lula ao continente como "patéticas aventuras", como apoio político e financeiro a ditaduras amigáveis ao PT. Nesse sentido, segundo Almeida, a retórica de Lula aparece descolada da realidade, não ocorrendo resultados concretos a partir dessa política. Ainda, Almeida afirma que a política externa do governo Lula é blindada pela comunidade acadêmica e pela imprensa em geral, uma vez que, segundo ele, a diplomacia de Fernando Henrique teria recebido muito mais críticas. ${ }^{393}$

Fica evidente, portanto, a mudança do tom das avaliações de Almeida em relação à política externa do governo Lula. Não é possível saber exatamente a razão dessa mudança, todavia fica visível que o autor adota críticas extremadas, sem o devido aprofundamento.

Essa visão crítica da política externa do governo Lula não é compartilhada pelo professor de Relações Internacionais da Universidade de Brasília José Flávio Sombra Saraiva. Especialista nas relações Brasil-África, que estuda desde a década de 80 e autor de vários livros e artigos sobre o tema ${ }^{394}$, Saraiva advogava por uma política externa brasileira devidamente voltada para África desde a década de 1990. Saraiva enxergou na eleição de Lula a possibilidade do "relançamento da política africana do Brasil", considerando as origens da aproximação brasileira ao continente africano na década de 1950 e um afastamento a partir da década de $1990^{395}$.

Saraiva faz referência aos "alarmistas" e "pessimistas", próximo dos argumentos de Pimentel, discutidos acima, pelos quais a África não tem o que oferecer ao Brasil nem o

\footnotetext{
${ }^{392}$ Ibidem, p. 13.

${ }^{393}$ Ibidem, p. 19 e 22.

${ }^{394}$ A obra mais recente com uma perspectiva histórica das relações Brasil-África é de autoria de Saraiva. Ver SARAIVA, José Flávio Sombra. O lugar da África: A dimensão atlântica da política externa brasileira (de 1946 a nossos dias). Brasília: UnB, 1996 e Do silêncio à afirmação: relações do Brasil com a África. In: Cervo, Amado Luiz (org.). O Desafio Internacional. Brasília: Ed. UnB, 1994.

${ }^{395}$ SARAIVA, José Flávio Sombra. Política Exterior do Governo Lula: o desafio africano. In: Revista Brasileira de Política Internacional, n. 45, v. 2, 2002, p. 1 e 7.
} 
Brasil tem algo a ganhar com a aproximação. Ao contrário, segundo Saraiva, o continente africano pode ser palco para o ensaio das possibilidades externas brasileiras, num cenário de benefícios mútuos. Adiantando os argumentos retóricos da diplomacia de Lula, está presente nos argumentos de Saraiva a dívida histórica com a África, lembrando que ali foi formada a "brasilidade". Além disso, está no horizonte de Saraiva o potencial geopolítico e econômico na aproximação com o continente africano.

(...) o relançamento da política africana do Brasil não seria apenas um ato de fé, mas o resultado de dois cálculos: um político e outro econômico. Politicamente, ela serve para reforçar a ideia de que o Brasil ainda tem um projeto cooperativo Sul-Sul, mas em outras bases, a engendrar alguma liderança nas novas rodadas de negociação de temas globais, na reformulação do Conselho de Segurança das Nações Unidas, na busca de parcerias estratégicas no Sul junto a países como a África do Sul, Índia e China. Além disso, uma política africana bem concertada com seus parceiros do outro lado pode constituir instrumento de barganha na vontade de reorientação do eixo diplomático de temas como o terrorismo para outros temas, mais construtivos e de interesse mútuo do Brasil e do continente africano, como o desenvolvimento sustentável e a cooperação Sul-Sul ${ }^{396}$.

Com essa linha de pensamento, já é possível perceber uma posição de defesa mais enfática da política externa do governo Lula por parte de Saraiva. Após o governo Lula, Saraiva afirma que vê uma renovada política externa para África, longe das bases de outrora, afastada principalmente do discurso culturalista e calcada nos interesses nacionais, notadamente econômicos. A "fronteira leste" do Brasil passa a ser local privilegiado da cooperação brasileira.

(...) a retomada da política africana do Brasil no início do novo século se realizou em novas bases. Possui, em primeiro lugar, uma estratégia concertada dos interesses nacionais e seus protagonistas, particularmente dos empresários da expansão do capitalismo brasileiro e dos agentes de diplomacia $^{397}$.

Ademais, segundo Saraiva, a renovação dessa política teria ocorrido também pelo consenso social e político na sociedade brasileira, por meio do congresso, das universidades,

\footnotetext{
${ }^{396}$ Ibidem, p. 15.

${ }^{397}$ SARAIVA, op. cit., 2012, p. 98.
} 
de grupos afro-brasileiros, de empresas e demais interessados ${ }^{398}$. Do mesmo modo, lideranças africanas teriam se identificado com o novo discurso brasileiro, após um breve momento de espera, desconfiados de um possível retraimento, como soía ocorrer com as política de aproximação com África. Ao contrário de Almeida, Saraiva apresenta diversas ações, principalmente as cooperativas, e enfatiza os arranjos Sul-Sul como plataformas comuns de interesses, trazendo benefícios mútuos para Brasil e África no sistema internacional. Para Saraiva, enfim, que considera a política externa do governo Lula para a África como uma "política africana", esse período significou a consolidação de uma política de permanência e continuidade em relação à "fronteira leste". 399

A posição de Saraiva é, dentre as analisadas, talvez a mais favorável à política externa brasileira para a África no governo Lula. Isso fica evidente com a afirmação que essa é uma "política africana", e pela perspectiva de que foi uma estratégica "concertada" entre interesses nacionais e agentes de política externa. No entanto, ainda mais considerando o período pósgoverno Lula, essas afirmações parecem por demais otimistas. Como pudemos analisar no capítulo 2, as ações e iniciativas brasileiras referentes ao continente africano não apresentam tanta conexão como Saraiva procura afirmar. Ainda é cedo, todavia, para dizer que a política do governo Lula permitiu a permanência de uma política para a África.

Ainda no meio acadêmico, o professor Paulo Fagundes Visentini também se especializou, no últimos anos, nas relações Brasil-África ${ }^{400}$, além de vários estudos sobre a projeção internacional do Brasil. Em sua obra mais recente, concentra-se nas relações BrasilÁfrica, de modo semelhante a Saraiva. Na sua concepção, a diplomacia para a África torna-se o principal foco da Cooperação Sul-Sul do governo Lula, especialmente nas áreas de comércio, investimento e cooperação, dentro do esquema da diplomacia "ativa, afirmativa e propositiva". Visentini enxerga três diferentes posições dos críticos à política de Lula, contrapondo os críticos da "diplomacia de prestígio" com os críticos da "diplomacia de negócios", na visão de quem a presença brasileira na África nada mais é do que um "imperialismo soft". Outra visão da política externa para a África seria a da "diplomacia solidária",401.

Visentini, desse modo, traz mais informações das relações Brasil-África do que em outras obras e artigos, mas ainda sem um aprofundamento mais metódico, contribuindo, de

\footnotetext{
${ }^{398}$ Ibidem, p. 99.

${ }^{399}$ Ibidem, p. 101.

${ }^{400}$ Nesse aspecto, ver PEREIRA e VISENTINI, 2014; VISENTINI, 2013; VISENTINI, 2016; e VISENTINI, Paulo Fagundes. BRICs as potências emergentes: China, Rússia, Índia, Brasil e África do Sul. Petrópolis: Vozes, 2013.

${ }^{401}$ VISENTINI, op. cit., 2016, p. 77.
} 
todo modo, para o debate mais informado sobre o tema. Diferentemente de Saraiva, ele não se posiciona explicitamente em posições de defesa ou crítica ao período. Considerando os laços históricos e a própria evolução da política externa brasileira para África, Visentini enxerga a aproximação como estratégia de projeção internacional.

Essa mudança na política externa brasileira é, portanto, justificada, por um lado, pela maior compreensão do governo da importância do apoio africano para aumentar a projeção do Brasil no cenário internacional, na sua estratégia de se inserir globalmente, cumprindo sua aspiração como potência emergente de porte médio. Por outro lado, a nova política também é justificada pelo Renascimento Africano, já que a África tem seu status reconhecido no cenário internacional, causado em grande parte pela valorização das commodities exportados pelo continente e pelo crescente investimento da China na região ${ }^{402}$.

Segundo Visentini, a política externa brasileira para a África foi multidimensional, com ênfase na diplomacia de prestígio (política), de negócios (econômica) e de cooperação (solidariedade). Na sua opinião, essas dimensões não são contraditórias, mas sim se complementam. Desse modo, concorda com Saraiva sobre ser uma fase diferente de momentos anteriores, como a PEI e os regimes militares, distanciando-se de estratégias "terceiro-mundistas". No entanto, segundo o autor, trata-se de um processo em curso, não livre de contradições. Faltaria mais coordenação dentro do próprio governo e com relação ao setor privado, além de insuficiência de recursos financeiros ${ }^{403}$.

Apesar da posição de Visentini fugir dos extremos, falta uma maior problematização das contradições - que afirma existirem - na política externa brasileira para a África. A complementaridade das dimensões, como afirma, não são bem conectadas, como pudemos estudar no capítulo anterior, especialmente a dimensão econômica. A falta de coordenação interna pode ser justamente a causa desse afastamento entre as chamadas dimensões.

Cabe ainda nesse capítulo um breve olhar nas análises de política externa realizadas por pesquisadores e acadêmicos das Relações Internacionais, pois elas trazem uma perspectiva intermediária entre as posições mais extremadas, indo além do discurso oficial e da crítica conservadora. Maria Regina Soares de Lima enfatiza que para se entender as orientações das políticas internacionais do país é preciso conhecer a inserção geopolítica do

\footnotetext{
402 Ibidem, p. 79.

${ }^{403}$ Ibidem, p. 176.
} 
Brasil, além da visão da comunidade de política externa ${ }^{404}$. Nesse sentido, aponta Lima, apesar das mudanças internas e externas nas últimas décadas, manteve-se a aspiração de um papel de protagonismo para o Brasil no cenário internacional. Para tanto, duas estratégias são delimitadas, quais sejam, a da busca por credibilidade e a autonomista.

A primeira parte da constatação que o Brasil não possui excedentes de poder e o fortalecimento de instituições multilaterais é a saída para o balanceamento da hegemonia unilateral no sistema internacional. A política externa deve ajustar as capacidades reais do país com os compromisso internacionais. A segunda procura projeção internacional, saindo de uma suposta posição defensiva, advinda da busca pela credibilidade. Daí decorre uma política externa ativa, em articulação com um projeto nacional de superação de desequilíbrios internos. Podemos então identificar os governos de Fernando Henrique e Lula com a primeira e a segunda estratégias, respectivamente. Apesar disso, afirma Lima, a diplomacia econômica multilateral dos dois governos não se distanciaram, apresentando uma relativa estabilidade da agenda diplomática:

(...) a revitalização e ampliação do Mercosul; a intensificação da cooperação com a América do Sul e com os países africanos; "relações maduras" com os Estados Unidos; importância das relações bilaterais com potências regionais como China, Índia, Rússia e África do Sul; ampliação do número de membros permanentes no Conselho das Nações Unidas; participação nos principais exercícios multilaterais em curso - Rodada de Doha da Organização Mundial do Comércio, negociação da Alca e entre Mercosul e União Europeia -, assim como na conformação das novas regras que irão reger as relações econômicas com vistas à defesa dos interesses dos países em desenvolvimento. ${ }^{405}$

A diferença entre os governos estaria na visão da ordem internacional de cada um. Inclusive, as bases da política macroeconômica ortodoxa implementada pelo governo Lula teriam sido iniciadas por Fernando Henrique; todavia, a política externa se distancia da estratégia da busca por credibilidade. A expressão "nova geografia mundial", e seus equivalentes, na opinião de Lima, sinaliza uma novidade da cooperação Sul-Sul, no contexto de globalização de mercados, num movimento conjunto de países emergentes nas questões multilaterais de comércio. Desse modo, afasta os argumentos críticos de que a política externa de Lula reaproximava-se da visão terceiro-mundista.

\footnotetext{
${ }^{404}$ LIMA, Maria Regina Soares de. A política externa brasileira e os desafios da cooperação Sul-Sul. In: Revista Brasileira de Política Internacional, n. 48, v. 1, 2005, p. 3.

405 Ibidem, p. 11-12.
} 
É curioso que com a crise do modelo de desenvolvimento com base nas importações e a abertura da economia brasileira, os defensores do novo status quo, de um modelo mais integrado aos mercados globais, insistam em visualizar estes dois papéis como antagônicos ou mesmo como soma-zero. Assim, quanto mais o Brasil se aproximasse de uma identidade de systemaffecting-state, mais ele estaria se afastando da de mercado emergente. Da mesma forma, a construção de relações estratégicas com os países do Sul é apresentada como substituta das relações com os países do capitalismo avançado, estas sim estratégicas para os interesses do país. O último argumento crítico consiste em levantar a questão da não complementaridade econômica entre os países do Sul e sua alegada condição de competidores no mercado global. ${ }^{406}$

A cooperação Sul-Sul não seria uma estratégia para substituir o relacionamento com Estados Unidos, Europa e Japão, mas sim um oportunidade para ampliar o comércio internacional brasileiro, considerando os mercados do Sul em suas complementaridades. Em relação ao IBAS, por exemplo, essas complementaridades podem ser maiores do que fatores competitivos, tendo em vista a semelhança de problemas estruturais de países de terceiro mundo, o que criaria uma base para a cooperação, em si distinta da antiga cooperação Norte$\mathrm{Sul}^{407}$.

As coalizões entre emergentes, como o IBAS, BRICS e G-20, segundo Lima, não podem ser caracterizados como um retorno aos agrupamentos terceiro-mundistas do passado, que tinham aspecto defensivo em relação ao cenário internacional e componente idealista. Os novos grupos procuram ultrapassar a estrutura centro-periferia característica das relações com os países do Norte, combinando revisionismo com propostas de fortalecimento da governança global, e, sobretudo, mantém explícito compromisso com valores democráticos ${ }^{408}$.

Uma das principais contribuições do governo Lula foi a restauração da política externa como instrumento da estratégia de desenvolvimento restabelecendo a vinculação que existiu no passado. Neste particular, a aproximação com os novos polos de poder cumpre papel estratégico. Do ponto de vista político e analítico, este movimento não deve ser enquadrado como mera política de prestígio, nem como retorno ao protagonismo brasileiro na liderança do G 77 no passado. Há ponderáveis interesses brasileiros em jogo, tendo em vista a consolidação do capitalismo brasileiro e sua projeção internacional ante as características da geopolítica das nações no século XXI. Como um participante ativo na economia globalizada, mas

\footnotetext{
${ }^{406}$ Ibidem, p. 31.

${ }^{407}$ Ibidem, p. 33.

${ }^{408}$ LIMA, op. cit., 2010, p. 166.
} 
sem o respaldo da capacidade nuclear-militar dissuasória, por decisão constitucional, o Brasil necessariamente terá de fazer uso da sua capacidade de concertação político-diplomática para fazer valer seus interesses na cena internacional. ${ }^{409}$

Nesse mesmo sentido, em estudo sobre o IBAS na política externa brasileira, os professores Janina Onuki e Amâncio Oliveira compartilham da visão de que as relações SulSul, em específico as coalizões entre emergentes, representam uma estratégia de inserção global, com limites e potencialidades. O IBAS, por exemplo, teria uma face defensiva e outra ofensiva. A primeira propõe-se a contrabalancear o poderio dos países desenvolvidos na construção do sistema internacional, enquanto a segunda trata-se da forma pela qual o Brasil se utiliza das relações Sul-Sul como ferramenta de influência no cenário internacional ${ }^{410}$. Desse modo, as relações Sul-Sul, criticadas como terceiro-mundistas, são vistas de uma perspectiva mais ampla, sendo analisadas não pela suposta falta de resultados mas sim pela adaptação a mudanças no plano global.

A presença do IBAS, bem como do BRICS, traduz uma nova realidade do ponto de vista de governança global. A alteração da correlação de forças no plano da governança global não é apenas um pleito dos países emergentes, mas sim uma necessidade imperativa de mudança que reflita a realidade atual das transformações do sistema internacional. ${ }^{411}$

Por fim, o professor Amado Cervo, por meio de uma perspectiva histórica, também analisa as relações Brasil-África. A partir da década de 1960, foram três os impulsos de aproximação entre Brasil e África. O primeiro momento ocorre no contexto da descolonização da década de 1960, impulsionado pelo multiculturalismo, reflexo das raízes multiétnicas e culturais brasileiras. O segundo impulso ocorre na sequência, com a consolidação da industrialização no Brasil, que o transforma em potencial exportador de manufaturados, e consequentemente, à busca de mercados. O terceiro momento ocorre com o potencial político e geopolítico da própria aproximação, na percepção de que o estreitamento de laços pode render melhores posições nas negociações internacionais. ${ }^{412}$

Ao mesmo tempo, existe a demanda por parte dos países africanos por cooperação para o desenvolvimento, principalmente em áreas de proximidade, nas quais o Brasil pode

\footnotetext{
${ }^{409}$ Ibidem, p. 174.

${ }^{410}$ ONUKI e OLIVEIRA, op. cit., 2013, p. 31.

411 Ibidem, p. 32.

${ }^{412}$ CERVO, Amado L. Inserção Internacional: formação dos conceitos brasileiros. São Paulo: Saraiva, 2008 , p. 294.
} 
oferecer expertise necessária. Além disso, o envolvimento com outros países, na posição dos africanos, significa a diminuição das dependências com as antigas metrópoles. A reaproximação com a África no governo Lula, além do discurso de resgate da dívida histórica, representa a aplicação de uma política realista, com o aumento do intercâmbio comercial e a participação das empresas brasileiras no continente africano, ampliando a internacionalização do capitalismo brasileiro ${ }^{413}$.

Cervo ainda discute que os argumentos de "retorno ao terceiro-mundismo" são parte de uma corrente de opinião conservadora, hegemônica nos anos 1990. O multiculturalismo, na opinião do autor, é característico da sociedade brasileira, que imprime o universalismo na política exterior brasileira, buscando a convivência das diferenças e a promoção da paz entre os povos.

O multiculturalismo oferece legitimidade e autenticidade ao universalismo das relações internacionais do País. Sem evitar a eleição de áreas prioritárias da ação externa, torna inconsistente e preconceituosa, ademais contrária à realização de interesses nacionais, a política de excluir espaços humanos e geográficos da penetração e presença brasileiras em nome de relações quase excludentes com os países avançados, como propõe uma forte corrente de opinião conservadora (...) Para esse segmento, imbuído de forte presunção, o conceito de Terceiro Mundo traduz uma excrescência do pensamento diplomático e cultivar relações com seus povos representa uma contaminação que deprime a qualidade da ação externa. (...) A corrente conservadora de opinião que postulava no passado o distanciamento do Terceiro Mundo e no presente, o distanciamento dos países emergentes, move-se por ignorância ou cálculos equivocados, senão mesmo por preconceitos. ${ }^{414}$

\subsection{Síntese}

Nesse capítulo, procuramos abordar a dimensão retórica da política externa brasileira para a África do governo Lula, selecionando discursos oficiais do presidente e de seu chanceler em contextos relacionados à África e às relações Sul-Sul, momentos nos quais há maior transparência nos objetivos e nas expectativas da diplomacia presidencial em relação ao continente africano. Buscamos também exemplificar o debate trazido por essa política externa no âmbito dos grandes jornais e dos formadores de opinião, que podem ser considerados parte

\footnotetext{
${ }^{413}$ Ibidem, p. 296.

${ }^{414}$ Ibidem, p. 294-295.
} 
da comunidade de política externa. Por fim, pontuamos alguns argumentos de pesquisadores e acadêmicos sobre o tema.

Algumas conclusões provisórias podem ser retiradas após a análise desses discursos. Em primeiro lugar, nessa análise precisamos considerar não apenas o conteúdo dos discursos mas também quem fala e em qual contexto onde é falado. Nos discursos oficiais, fica evidente a narrativa positiva em relação ao movimento de aproximação brasileiro ao continente africano. Os argumentos sobre a dívida histórica e laços entre os povos são narrativas de aproximação com o público-alvo. O interessante no caso dos discursos de Lula é a evolução de alguns temas e a repetição de outros. Nesse sentido, a retórica de Lula vai ganhando corpo conforme as próprias relações vão adquirindo realidade prática, como o aumento do comércio, o crescente número de projetos de cooperação e os investimentos brasileiros. A repetição de temas como a reforma do CSONU e da construção de uma nova ordem mundial refletem a própria visão de mundo da política externa desse período, que também vai ganhando mais apoio conforme as ações brasileiras não ficam apenas na retórica. Entretanto, a retórica oficial evidencia a idealização das relações entre Brasil e África. Ao passo que reflete as iniciativas ao longo do tempo, o discurso evita ou mesmo omite quaisquer tipos de problemas, esconde os interesses econômicos que inevitavelmente existem, ou seja, deixa de lado qualquer discussão mais aprofundada.

Em segundo lugar, a narrativa dos grandes jornais segue o sentido de desconstrução das iniciativas brasileiras, muitas vezes carregadas de preconceitos, com o "complexo de caiação" evidente, em relação aos países africanos, mas também em franca oposição à visão de mundo do governo Lula. Fica nítida a posição dos jornais quanto ao discurso de Lula sobre a "nova geografia mundial", defendendo as relações tradicionais com Estados Unidos e Europa, em detrimento ao mundo emergente. A ênfase da crítica sempre recai no aspecto econômico-comercial, na insistência da prioridade de "parceiros tradicionais". Não há discussão de possibilidades ou potenciais, ao contrário, são enfatizados sempre os piores aspectos dos países africanos, como pobreza, desigualdade, doenças, endividamento, evidenciando, ao fim, a permanência do complexo de caiação, que José Honório Rodrigues observava na década de 1960.

Em terceiro lugar, os exemplos aqui utilizados da comunidade de política externa representam apenas um dos polos desse debate. Nem toda comunidade é polarizada nesse contexto político-ideológico, e não se tentou aqui uma seleção exaustiva. $O$ ponto a ser observado aqui reside no fato de os autores escolhidos serem diplomatas, esperando-se assim argumentos mais sólidos, ainda que apresentados em artigos, não numa obra com mais fôlego. 
No entanto, o que se observa é uma argumentação sobre a "partidarização" e "ideologização" da política externa, vítima do comportamento "terceiro-mundista" do governo no poder. As menções diretas à África são reduzidas em termos econômico-comerciais e relações com países não democráticos. Gasta-se mais energia na crítica ao discurso oficial, sem aprofundamento analítico das ações e iniciativas, as quais, se devidamente analisadas, não ficariam livres de questionamentos.

Em quarto lugar, os analistas acadêmicos, ao contrário dos diplomatas, empreendem análises mais cuidadosas, tanto nas relações Brasil-África especificamente, quanto no contexto mais geral das relações Sul-Sul. Saraiva destoa um pouco na análise da política externa do governo Lula por ser antigo defensor do aprofundamento das relações, e enxergar nesse governo, com razão, uma maior atenção ao continente africano, algo que não se via há algum tempo. De todo modo, faz um trabalho mais cuidados ao tratar das iniciativas brasileiras para África, assim como Visentini. Mas não há um detalhamento das dimensões comerciais e cooperativas, por exemplo.

Finalmente, na área de Política Internacional propriamente dita, a análise não se centra especificamente nas relações externas Brasil-África, mas sobre a própria inserção do Brasil no cenário internacional, como discute Maria Regina Soares, por exemplo, e por quais meios isso ocorre, além de observar a própria mudança do contexto internacional. A análise vai além do discurso oficial, com a pesquisa de dados tanto comerciais quanto de opinião pública, como no caso da professora Janina, por exemplo, permitindo uma maior qualificação dos argumentos e se afastando de uma posição eminentemente política, como pode ser interpretado das grandes mídias e dos diplomatas aqui selecionados.

A retórica do governo Lula, ao fim, se entrelaça com as dimensões e esferas aqui analisadas da política externa brasileira para África. O próprio desenvolvimento de iniciativas, como o aumento de projetos de cooperação ou a consolidação de arranjos cooperativos alimentam a narrativa de Lula em relação à África, utilizando-a também como um instrumento de política externa, aliada a sua intensa atividade de diplomacia presidencial. 


\section{Conclusão}

Este trabalho procurou analisar as relações externas entre Brasil e África dentro de um recorte temporal iniciado com as independências africanas até o período recente do governo Lula. O grande debate, seja na mídia seja no âmbito acadêmico, sobre a política externa do governo Lula em grande medida incentivou a pesquisa aqui apresentada no sentido de se buscar, na história da política exterior do Brasil, a existência de uma "política externa brasileira para África propriamente dita", ou seja, uma diplomacia que se sustentasse em bases sólidas ao longo do tempo, superando mudanças internas e externas. A primeira impressão, ao propor essa pesquisa, era de que o governo Lula tinha representado, finalmente, a consolidação da África na agenda externa brasileira, algo que, na minha opinião pessoal, é de extrema importância, dada a participação africana na identidade brasileira, muitas vezes sufocada.

Entretanto, ao longo da pesquisa e principalmente durante os levantamentos de informações e discussões acerca do governo Lula, passei a ter o devido distanciamento do tema, a fim de construir uma visão mais crítica sobre a formulação da política externa para África. Os debates na mídia e artigos de opinião, como estudados no terceiro capítulo, acabam sendo a porta de entrada para o assunto, polarizando de início o debate e escondendo uma problematização maior do tema.

A análise em perspectiva histórica das relações Brasil-África de 1961 até o fím do governo Fernando Henrique permitiu concluir que elas sofreram de constante instabilidade, apesar de que não foram em nenhum momento "silenciadas". Conjunturas internas e externas serviram de obstáculo para o aprofundamento de iniciativas que ocorreram no período. Algumas delas foram a influência portuguesa na política externa brasileira; o golpe militar e a consequente mudança de orientação; e as diferentes crises econômicas, principalmente na década de 1980. Alguns chanceleres do período, como Afonso Arinos, Mario Gibson Barboza, Azeredo da Silveira e Saraiva Guerreiro, tiveram o mérito de defender e manter o possível de uma atitude brasileira em relação ao continente africano. Ao fim, as relações não tiveram aprofundamento, e não é possível afirmar a existência de uma política externa africana no período. Retomando o quadro síntese apresentado ao fim do capítulo 1, não é exagero colocar que a intensidade das relações no governo de Lula foi a maior até então, com muitas iniciativas positivas.

A política externa do governo Lula, em perspectiva com os período anteriores, apresentou diferenças, ainda que mais na visão de mundo do que em rupturas significativas 
das linhas diplomáticas. Entretanto, se houve realmente uma mudança expressiva na diplomacia brasileira, essa mudança estava relacionada com a política exterior em relação ao continente africano. Mesmo considerando pontos em comum das iniciativas do governo Lula com governos anteriores - no que se refere à África - a profundidade e abrangência das ações foram diversas. Esse é um dos pontos nos quais esse trabalho pretende problematizar e contribuir. Essas diferenças foram suficientes para a consolidação de uma política externa para África? Em outras palavras, o continente africano consegue um lugar na agenda diplomática brasileira para além do discurso culturalista tradicional?

Em relação ao governo Lula, o objetivo deste trabalho foi investigar como isso ocorreu. Para tanto, ao analisar a política como um todo, denominamos de dimensões e esferas os diferentes aspectos dela, trabalhando com a hipótese da existência de uma coerência interna em relação a diferentes áreas, como comércio e cooperação, por exemplo. De forma a viabilizar esse objetivo, foi realizado extenso levantamento de dados e informações a respeito das relações políticas, comerciais, econômicas e cooperativas. Além disso, trabalhamos com uma seleção de discursos oficiais, de editoriais da grande mídia e de análises acadêmicas da comunidade de política externa a fim de procurar a relação da retórica diplomática com as dimensões da política externa e da repercussão dessa na opinião pública qualificada.

Foi possível observar que o governo Lula aproximou-se da África desde o início do mandato, conforme anunciado no próprio programa de governo do PT. No entanto, a política externa adotada em seu governo não é um simples resultado partidário. A política externa para a África resulta de uma convergência da visão de mundo tanto do partido quanto de Lula, e dos quadros existentes no MRE, que desde a década de 1960, como estudado, vêm formulando iniciativas nesse sentido - devemos considerar que Celso Amorim é influenciado pelos diplomatas que estão discutindo o lugar da África na diplomacia brasileira na década de 1960, momento em que entra no corpo diplomático. Além disso, o período de Lula coincide com um novo contexto internacional favorável para essa política, que se benéfica também da próprio carisma do presidente e do uso intensivo da diplomacia presidencial

O auge das relações ocorre no segundo mandato, considerando o número de projetos de cooperação, o aumento do intercâmbio bilateral e de investimentos. As visitas de Estado e abertura de embaixadas foram mais constantes ao longo do período. A partir da análise da dimensão retórica, é possível também observar a evolução das iniciativas; ou seja, não podemos concluir que o resultado dessa política, ao final do período, já era antevisto quando das primeiras ações a respeito, como o primeiro périplo e a abertura de embaixadas. A 
continuidade da dimensão política, por meio das ações multilaterais e bilaterais dava crédito à política externa brasileira em relação aos líderes africanos, que passam a buscar a cooperação brasileira.

Conforme foi estudado, foi possível observar uma relação próxima entre a dimensão política na esfera bilateral com a dimensão cooperativa. Não só as visitas de Estado, mas principalmente a abertura de embaixadas significou a consolidação de um canal de comunicação pelo qual países africanos tiveram acesso aos projetos de cooperação técnica, científica e educacional brasileiros. A experiência brasileira, principalmente nas áreas de educação, saúde e agricultura, foi levada aos africanos, a partir de demandas dos próprios países. O grande crescimento observado ocorre após o aporte de orçamento da ABC, que é o órgão responsável pela coordenação de projetos.

A dimensão cooperativa, tanto nas esferas humanitária, quanto para o desenvolvimento internacional, talvez seja a mais importante das dimensões em questão de aprofundamento das relações, mas ao mesmo tempo não aparece tanto nas discussões sobre as relações. Por um lado, é uma iniciativa de relativo baixo custo ao Brasil, tanto pelo pequeno aporte orçamentário da $\mathrm{ABC}$ - se comparado com outras agências análogas -, quanto pela participação de diversos ministérios e órgãos na cooperação, que cedem seus profissionais aos projetos, baixando os custos totais.

Por outro lado, são ações de impacto profundo nos países recipientes, pois diferentemente da assistência internacional, mais baseada em doações, a cooperação brasileira colabora para o fortalecimento de instituições que a longo prazo poderiam assegurar o próprio desenvolvimento do país recipiente. Além disso, o crescimento da cooperação para além dos parceiros tradicionais - como os PALOPs, por exemplo - aumenta ainda mais a imagem internacional do Brasil, permitindo somar ainda mais na conta do soft power.

No caso da dimensão econômica, a conexão com as outras dimensões é mais tênue. A esfera política bilateral, mais especificamente as visitas de Estado, foram essenciais para o estímulo de agentes econômicos - os empresários e as empreiteiras - para investirem no continente africano. Nesse caso, a participação do Estado, na figura do presidente Lula, foi fundamental para a maior presença de empresas brasileiras em mais países africanos, indo além da presença antiga das grandes empresas como Petrobrás, Vale e Odebrecht, em países como Angola. Nesse sentido, a dimensão política fez o papel de aproximar partes que em grande medida se desconheciam, e a presença de novas embaixadas também serviu ao papel de canal de comunicação. 
O estudo mais detalhado do processo de perdão de dívidas contribui para o debate, na medida que deixa mais evidente o andamento das negociações e trâmites dessa iniciativa. Além de ser uma medida que aproxima as dimensões econômicas e cooperativas, o perdão é utilizado instrumento de retórica, tanto nas narrativas oficiais quanto nos argumentos da oposição. No entanto, é pouca a coesão da dimensão econômica com a cooperativa, e, ainda, entre as esferas de investimento e comerciais. Não é possível afirmar uma relação direta entre o aumento do intercâmbio comercial e os investimentos brasileiros, ou ainda, com a dimensão cooperativa.

As dimensões da política externa para a África, conforme construídas aqui, não encontram, portanto, plena convergência entre si, pois, ao final, cumprem diferentes objetivos. Ao passo que a dimensão retórica, considerando os discursos oficiais, se alimenta do desenvolvimento das outras dimensões e ajuda a construir a imagem do Brasil como país emergente no cenário internacional, a dimensão econômica segue um caminho mais ou menos paralelo, orientado pela participação do Estado. A dimensão cooperativa, cujas bases já estavam consolidadas anteriormente, testemunha um aumento de atividade e orçamento em consequência da priorização das relações com a África, mas sofre uma séria limitação orçamentária e de pessoal, na falta de institucionalização da $\mathrm{ABC}$, que continua possuindo pouca autonomia dentro do MRE. Por isso mesmo, cabe questionar se as iniciativas de cooperação terão sustentabilidade, no caso da continuidade desse quadro.

Com isso em mente, seria possível responder o questionamento de José Honório Rodrigues quanto à existência de uma política africana? A resposta talvez dependa do ponto de vista. Caso se considere uma política africana um lugar definido da África na agenda brasileira, é possível dizer que sim. A questão é se esse lugar vai ser mantido. Devemos observar se essa política se enraizou na diplomacia brasileira, deixando de lado o discurso culturalista que sempre a caracterizou.

A diplomacia para África apresentou contradições e limitações. Faltou maior coordenação de todas as chamadas dimensões, algo que a retórica oficial não consegue impor, mesmo refletindo - e aumentando - a realidade. A dimensão econômica, por exemplo, não é uma política africana, no sentido de ser formulada tendo em vista interesses mútuos e benefícios recíprocos. Tanto o investimento quanto o intercâmbio comercial respondem mais a conjunturas internacionais do que a estímulos autênticos. Percebe-se ainda que as empreiteiras não geraram recursos ou ativaram cadeias produtivas na África.

Por outro lado, a cooperação para o desenvolvimento chega mais perto dessa ideia de política africana, pois concentra-se num elemento de solidariedade e horizontalidade, apesar 
da narrativa oficial negar que existe, ao fim e ao cabo, um relacionamento de troca, não material mas de influência, dando mais corpo ao soft power brasileiro. Neste sentido, pode-se inclusive afirmar que o objetivo dessa política era garantir um espaço no território africano para exercer hegemonia, frente a outros atores emergentes, como Índia e China. Ainda assim, é uma afirmação discutível, pois o Brasil não possui elementos suficientes para enfrentar potências como a China.

Desse modo, não é possível afirmar, como vimos desenvolvendo, que a política externa do governo Lula foi realmente africana em sua totalidade. O mérito desse período, no entanto, é considerável, haja vista a extensão que as relações Brasil-África receberam no período do governo Lula, podendo levar a um enraizamento da política externa para África, na medida que permite o aumento do conhecimento mútuo, para além das relações já tradicionais.

Mesmo com uma mudança de governo que significa uma reviravolta na visão de mundo, parece difícil o retorno a um quadro igual ao dos anos 1990. No governo Dilma, dada a falta de iniciativa para a África, as relações Brasil-África foram deixadas na inércia do governo anterior. Na completa ausência de uma diplomacia presidencial, houve recuos em todas as dimensões, principalmente na econômica e na cooperativa. A tal ponto ocorreu o refluxo que foi solicitado, pelo chanceler interino, José Serra, estudos de viabilidade em relação às embaixadas brasileiras na África, o que pode significar um retrocesso nas relações bilaterais. Mas somente nos próximos anos, no entanto, poderemos ver se a falta da participação do Estado no estímulo das relações econômicas levará novamente a um afastamento, com a consequente retração de relações políticas e cooperativas.

O período presente, no entanto, não é o foco deste trabalho. Procuramos desenvolver questões a partir de ferramentas conceituais com o objetivo de averiguar a intensidade das Relações Brasil-África, ao longo de diversos momentos. Comparativamente, o governo Lula demonstrou uma maior intensidade com relação à África. Diversos elementos contribuíram para tanto, como a própria liderança do presidente, a conjuntura econômica internacional, o ciclo de expansão da econômica brasileira e também o crescimento econômico africano. No entanto, retomando a nossa questão norteadora, foi configurada uma política africana? Tudo indica, considerando também os anos após o governo Lula, que tal política se enraizou, de fato, mais no plano retórico do que na prática. 


\section{REFERÊNCIAS BIBLIOGRÁFICAS}

ABDENUR, Adriana e SOUZA NETO, Danilo M. O Atlântico Sul e a cooperação em defesa entre o Brasil e a África. In: NASSER, Reginaldo Mattar. O Brasil e a segurança no seu entorno estratégico: América do Sul e Atlântico Sul. Brasília: IPEA, 2014.

ALENCASTRO, Luiz Felipe de. O trato dos viventes: formação do Brasil no Atlântico Sul. São Paulo: Cia. Das Letras, 2000.

ALMEIDA, Paulo Roberto de. A Política Internacional do Partido dos Trabalhadores: da fundação à diplomacia do governo Lula. In: Revista de Sociologia Política, n. 20, jun. 2003.

A política internacional do PT e a diplomacia do governo Lula. In: ALBUQUERQUE, José A. Guilhon. Sessenta anos de política externa brasileira:19301990, v. 1, Rio de Janeiro: Lumen Juris, 2006.

A diplomacia da era Lula: balanço e avaliação. In: Revista Política Externa, v. 20, n. 3, 2012. Disponível em http://politicaexterna.com.br/503/diplomacia-era-lula-balancoavaliacao/

AMADO, Rodrigo. Araújo Castro. Brasília: Ed. UnB, 1982.

AMORIM, Celso. Breves Narrativas Diplomáticas. São Paulo: Benvirá, 2013.

BANCO do Brasil. Intercâmbio comercial, 1953-1976. V. 1. Rio de Janeiro: Banco do Brasil, 1977.

BARBOSA, Rubens. Política Externa de dois governos. 8o Fórum de Economia da FGV, 2011. Disponível em http://cnd.fgv.br/node/303.

BARBOZA, Mario Gibson. Na Diplomacia, o traço todo da vida. Rio de Janeiro: Francisco Alves Editora, 2007.

BARRETO, Fernando de Mello. A política externa após a redemocratização. Brasília: FUNAG, 2012.

BAUMANN, Renato. BRICS: Oportunidade e desafio para a inserção internacional do Brasil. In: et al. BRICS: estudos e documentos. Brasília: FUNAG, 2015.

BECARD, Danielly Silva Ramos. Relações Exteriores do Brasil Contemporâneo. Petrópolis: Vozes, 2009.

BETHELL, Leslie. A abolição do comércio brasileiro de escravos. Brasília: Senado Federal, 2002.

BOBIASH, Donald. South-South Aid: how developing countries help each other. Londres: Macmillan Press, 1992.

BRASIL. MRE. Legislação MRE. Brasília: MRE, SGEX, 2008. 
CANDEAS, Alessandro. Trópico, Cultura e Desenvolvimento: a reflexão da UNESCO e a tropicologia de Gilberto Freyre. Brasília: Liber Livro, 2010.

CASARÕES, Guilherme Stolle Paixão e. A mídia e a política externa no Brasil de Lula. In: Austral, v. 1, n. 2, 2012.

CERVO, Amado L. e BUENO, Clodoaldo. História da Política Exterior do Brasil. $3^{\text {a }}$ Edição. Brasília: Ed. UNB, 2008.

CERVO, Amado L. Inserção Internacional: formação dos conceitos brasileiros. São Paulo: Saraiva, 2008.

CENTRO DE HISTÓRIA E DOCUMENTAÇÃO DIPLOMÁTICA. Cadernos do CHDD. Ano V, n. 8. Brasília: Centro de História e Documentação Diplomática, FUNAG, 2006.

CORRÊA, Luiz Felipe de Seixas. O Brasil nas Nações Unidas: 1946-2011. Brasília: FUNAG, 2012.

CRUZ, José Humberto de Brito. Aspectos da Evolução da Diplomacia Brasileira no Período da Política Externa Independente. In: Danese, Sérgio França (org.). Ensaios de História Diplomática do Brasil (1930-1986). Cadernos do IPRI, n.2, Brasília: FUNAG, 1989.

DAMICO, Flávio. Antecedentes: do acrônimo de Mercado à concertação politicodiplomática. In: BAUMANN, Renato et al. BRICS: estudos e documentos. Brasília: FUNAG, 2015.

DANESE, Sergio. Diplomacia Presidencial. Rio de Janeiro: Topbooks, 1999.

DANTAS, Francisco Clementino de San Tiago. Política Externa Independente. Brasília: FUNAG, 2011.

DÁVILA, Jerry. Hotel Trópico. São Paulo: Paz e Terra, 2012.

FOOD AND AGRICULTURE ORGANIZATION OF THE UNITED NATIONS. Verbatim Records of Plenary Meetings of the 37th Conference, 2011.

FARIAS, Rogério e CARMO, Géssica. Do Circuito Elizabeth Arden ao Circuito Global? A política de postos e remoções do Itamaraty. In: Mundorama - Revista de Divulgação Científica em Relações Internacionais, [acessado em 16/06/2015]. Disponível em: $<$ http://www.mundorama.net/2015/06/16/do-circuito-elizabeth-arden-ao-circuito-global-apolitica-de-postos-e-remocoes-do-itamaraty-por-rogerio-de-souza-farias-e-gessica-carmo/>

FERREIRA, Walace. A Política Externa para a África dos governos FHC e Lula: uma análise comparada. Tese UERJ, 2015.

FONSECA JR., Gelson. Legitimidade e outras questões internacionais. São Paulo: Paz e Terra, 1998.

FRANCO, Afonso Arinos de Melo. Planalto: Memórias. Rio de Janeiro: José Olympio, 1968.

FRANCO, Álvares da Costa (org.). Documentos da Política Externa Independente, vol. 1. Brasília: FUNAG, 2007. 
INSTITUTO BRASILEIRO DE GEOGRAFIA E ESTATÍSTICA. Anuário Estatístico do Brasil, 1963.

IPEA. Ponte sobre o Atlântico: Brasil e a África Subsaariana Parceria Sul-Sul para o crescimento. IPEA, 2012.

JAKOBSEN, Kjedl Aagard. Desventuras de alguns críticos da política externa do governo Lula. In: Lua Nova, n. 89, 2013.

KORNEGAY, Francis. África do Sul, Atlântico sul e a equação IBAS-BRICS: o espaço transatlântico em transição. In: Austral, v.2, n. 3, 2013.

LAMPREIA, Luiz Felipe. O Brasil e os ventos do mundo: memórias de cinco décadas na cena internacional. Rio de Janeiro: Objetiva, 2012, recurso eletrônico.

LAUTENSCHLAGER, Alexandre e CATERMOL, Fabrício. A participação das exportações brasileiras no comércio mundial de bens de capital para a África. In. BNDES Setorial n. 34, 2001.

LEITE, Iara Costa. Cooperação Sul-Sul: Conceito, História e marcos interpretativos. In: Observador On-line, v. 7, n. 3, mar. 2012.

LEITE, Patrícia Soares. Brasil e a Cooperação Sul-Sul em três momentos de Política Externa. Brasília: Funag, 2011.

LIMA, Manuel de Oliveira. O império brasileiro: 1822-1889. Brasília: Ed. UnB, 1986.

LIMA, Maria Regina Soares de. LIMA, Maria Regina Soares de. A política externa brasileira e os desafios da cooperação Sul-Sul. In: Revista Brasileira de Política Internacional, n. 48, v. 1, 2005.

. Brasil e os polos emergentes do poder mundial: Rússia, Índia, China e África do Sul. In: BAUMANN, Renato. O Brasil e os demais BRICs - comércio e política. Brasília: IPEA, 2010.

LIMA, Maria Regina Soares de; e HIRST, Monica. A Iniciativa IBAS e a cooperação SulSul: desafios intelectuais e possibilidades políticas. In: Brasil, Índia e África do Sul: desafios e oportunidades para novas parcerias. São Paulo: Paz e Terra, 2009

MARQUESE, Rafael de Bivar e PARRON, Tâmis. Azeredo Coutinho, Visconde de Araruama e a Memória de Escravos de 1838. In: Revista de História, n. 152, 2005.

MATTOSO, Kátia M. De Queirós. Ser Escravo no Brasil. São Paulo: Brasiliense, 2003.

MELO, Ovídio de Andrade. Recordações de um removedor de mofo no Itamaraty. Brasília: FUNAG, 2009.

MELLO E SOUZA, André. Repensando a cooperação internacional para o desenvolvimento. In: Repensando a cooperação internacional para o desenvolvimento. Brasília: IPEA, 2014. 
MENDONÇA JÚNIOR, Wilson. Política Externa e Cooperação Técnica: As relações do Brasil com a África durante os anos FHC e Lula. Belo Horizonte: D’Plácido Editora, 2013. Recurso Eletrônico.

MENEZES, Adolpho Justo Bezerra de. Ásia, África e a Política Independente do Brasil. Rio de Janeiro: Zahar, 1961.

MOURÃO, Fernando A. A. e OLIVEIRA, Henrique Altemani. Política Africana no Brasil. In: ALBUQUERQUE, José A. Guilhon. Sessenta anos de política externa brasileira: o desafio geoestratégico. São Paulo: Annablume, 2000.

O processo de definição da Política Externa Africana no Brasil. In: OLIVEIRA, Henrique Altemani e ALBUQUERQUE, José A. Guilhon. A Política Externa Brasileira na Visão de seus Protagonistas. Rio de Janeiro: Ed. Lumen Juris, 2005.

OLIVEIRA, Henrique Altemani. Política Externa Brasileira e Relações Comerciais BrasilÁfrica. Tese de Doutorado. FFLCH-USP, 1987.

OLIVEIRA, Marcelo Fernandes de. Estratégias internacionais e diálogo Sul-Sul no governo Lula: alianças duradouras ou coalizões efêmeras? In: VILLARES, Fábio (org.). Índia, Brasil e África do Sul: perspectivas e alianças. São Paulo: Unesp, 2006.

ONUKI, Janina e OLIVEIRA, Amâncio Oliveira. O espaço do IBAS na Política Externa Brasileira. In: LESSA, Antônio e OLIVEIRA, Henrique Altemani. Parcerias estratégicas do Brasil: a dimensão multilateral e as parcerias emergentes. Belo Horizonte: Fino Traço, 2013.

PENNA FILHO, Pio. O Brasil e a África do Sul: o arco atlântico da política externa brasileira (1918-2000). Porto Alegre: FUNAG, 2008.

PENHA, Eli Alves. Relações Brasil-África e geopolítica do Atlântico Sul. Salvador: EDUFBA, 2011.

e LESSA, Antonio Carlos Moraes. O Itamaraty e a África: as origens da política africana do Brasil. In: Estudos Históricos, Rio de Janeiro, n. 39, jan-jun 2007, p. 57-81.

PEREIRA, Analúcia Danilevicz. A Política Externa do Governo Sarney: A Nova República diante do reordenamento internacional (1985-1990). Porto Alegre: UFRGS, 2003.

Vozes, 2014.

e VISENTINI, Paulo Fagundes. História da África e dos Africanos. Petrópolis:

PIMENTEL, José Vicente de. Relações entre o Brasil e a África Subsaárica. In: Revista Brasileira de Política Internacional, n. 43, 2000.

PINHEIRO, Letícia. Brasil, Portugal e a descolonização africana (1946-1960). In: Contexto Internacional, v. 9, n. 5, 1989.

PINO, Bruno Ayllón. O Sistema Internacional de Cooperação ao Desenvolvimento e seu estudo nas Relações Internacionais: a evolução histórica e as dimensões teóricas. In: Revista de Economia e Relações Internacionais, v. 5 (8), 2006. 
. Evolução Histórica da Cooperação Sul-Sul. In: Repensando a Cooperação Internacional para o Desenvolvimento. Brasília: IPEA, 2014.

PINTO, Paulo Cordeiro de Andrade. Brasil África: relações privilegiadas In: RBCE 116.

PRESIDÊNCIA da República. Discurso do Presidente da República. Secretaria de Imprensa e Divulgação, 2003.

RANGEL, Ignácio. África e outros novos mercados. In: Tempo Brasileiro, II, dez. 1962.

REIS, Daniel Aarão (coord.). Modernização, Ditadura e Democracia. Rio de Janeiro: Ed. Objetiva, 2014.

RIBEIRO, Cláudio Oliveira. Relações Político-Comerciais Brasil-África (1985-2006). Tese FFLCH-USP, 2007.

. Crise e Castigo: as relações Brasil-África no governo Sarney. In: Revista Brasileira de Política Internacional, n. 51, v.2, p. 41, 2008.

RODRIGUES, José Honório. Interesse Nacional e Política Externa. Rio de Janeiro: Civilização Brasileira, 1966.

. Aspirações Nacionais - Interpretação Histórico-Política. Rio de Janeiro: Civilização Brasileira, 1970.

. Brasil e África: Outro Horizonte. Rio de Janeiro: Nova Fronteira, 1982.

ROSSI, Amanda. Moçambique, o Brasil é aqui. Rio de Janeiro: Record, 2015.

SARAIVA, José Flávio Sombra. Do silêncio à afirmação: relações do Brasil com a África. In: Cervo, Amado Luiz (org.). O Desafio Internacional. Brasília: Ed. UnB, 1994.

Política Exterior do Governo Lula: o desafio africano. In: Revista Brasileira de Política Internacional, n. 45, v. 2, 2002.

África Parceira do Brasil Atlântico: relações internacionais do Brasil e da África no início do século XXI. Belo Horizonte: Fino Traço, 2012.

SILVA, Alberto da Costa e. O Vício da África e outros vícios. Lisboa: João Sá da Costa, 1989.

Um Rio Chamado Atlântico: a África no Brasil e o Brasil na África. Rio de janeiro: Nova Fronteira, 2011.

SOUZA DANTAS, Raymundo. África Difícil: Missão Condenada. Rio de Janeiro: Editora Leitura, 1965.

SPEKTOR, Matias. Azeredo da Silveira: um depoimento. São Paulo: Ed. FGV, 2010.

STUENKEL, Oliver. India-Brazil-South Africa dialogue forum (IBSA): the rise of the global south. Nova Iorque: Routledge, 2015a.

The BRICS and the future of global order. Londres: Lexington Books, $2015 \mathrm{~b}$. 
VEIGA, Pedro da Motta. A África na agenda econômica do Brasil: comércio, investimentos e cooperação. In RBCE, 116, 2013.

VIEITAS, Deborah e ABOIM, Isabel. África: Oportunidades para empresas brasileiras. In: Revista Brasileira de Comércio Exterior n. 116.

VISENTINI, Paulo Fagundes. A Política Externa do Regime Militar Brasileiro: multilateralização, desenvolvimento e a construção de uma potência média (1964-1985). Porto Alegre: Ed. UFRGS, 1998.

Relações Exteriores do Brasil II (1930-1964): o nacionalismo, da Era Vargas à Política Externa Independente. Petrópolis: Vozes, 2009.

A projeção internacional do Brasil: 1930-2012. Rio de Janeiro: Elsevir, 2013. Books, 2016.

A relação Brasil-África: prestígio, cooperação ou negócios? Rio de Janeiro: Alta

\section{LISTA DE ENTREVISTAS}

CARNEIRO, Carla Barroso e GIRARDI, Filipe. Assessora Especial para Assuntos Internacionais e Coordenador de África, Ásia, Oceania, Oriente Médio e Língua Portuguesa do Ministério da Educação. Entrevista concedida ao autor. Brasília, abril de 2016.

LIMA, Paulo Barbosa. Gerente de Cooperação Sul-Sul (PALOP e Timor-Leste) da Agência Brasileira de Cooperação. Entrevista concedida ao autor. Brasília, abril de 2016.

NOGUEIRA, Paulo César e BUENO, Adriana. Coordenadores de Cooperação Técnica da Embrapa. Entrevista concedida ao autor. Brasília, abril de 2016.

RONDÓ FILHO, Milton. Coordenador-Geral de Ações Internacionais de Combate à Fome do Ministério das Relações Exteriores. Entrevista concedida ao autor. Brasília, abril de 2016.

VERGNE, Isaac. Assessor Técnico da Assessoria de Assuntos Internacionais de Saúde do Ministério da Saúde. Entrevista concedida ao autor. Brasília, abril de 2016. 